\title{
A Pré-Fabricação em Concreto Armado Aplicada a Conjuntos Habitacionais no Brasil: \\ O caso do "Conj unto Habitacional Zezinho Magalhães Prado"
}

\section{Fabiana Cerávolo}

\begin{abstract}
Dissertação apresentada à Escola de Engenharia de São Carlos da Universidade de São Paulo, como parte dos requisitos para obtenção do título de Mestre em Arquitetura e Urbansimo.
\end{abstract}

Orientador: Miguel Antônio Buzzar

São Carlos, agosto de 2007. 
AUTORIZO A REPRODUÇÃO E DIVULGAÇ̃̃O TOTAL OU PARCIAL DESTE TRABALHO, POR QUALQUER MEIO CONVENCIONAL OU ELETRÔNICO, PARA FINS DE ESTUDO E PESQUISA, DESDE QUE CITADA A FONTE.

Ficha catalográfica preparada pela Seção de Tratamento da Informação do Serviço de Biblioteca - EESC/USP

\footnotetext{
Cerávolo, Fabiana
C411p A pré-fabricação em concreto armado aplicada á conjuntos habitacionais no Brasil : o caso do conjunto habitacional Zezinho Magalhães Prado/ Fabiana Cerávolo ; orientador Miguel Antônio Buzzar, 2007.

Dissertação (Mestrado-Programa de Pós-Graduação em Arquitetura e Urbanismo. Área de Concentração : Teoria e História da Arquitetura e do Urbanismo) -- Escola de Engenharia de São Carlos da Universidade de São Paulo, 2007.
}

1. Habitação. 2. Industrialização. 3. Conjunto habitacional. 4. Zezinho Magalhães Prado. I. Título. 
DEDICATÓRIA

Dedico aos meus pais, que sempre acreditaram em mim. 


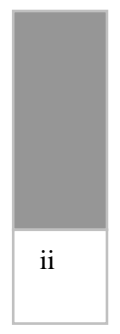


A CNPQ, cujo financiamento, através da bolsa de mestrado de dois anos, viabilizou a realização deste trabalho.

Ao meu orientador Professor Doutor Miguel Antonio Buzzar pela paciência e confiança em meu trabalho.

Aos colaboradores Fábio Penteado, Fernando Gonçalves, Maria Giselda Cardoso Visconti, Mário Savioli, Sônia Sparlatore, Solimar Mendes, pessoas que sem dúvidas contribuíram muito para esse trabalho.

A Ana Lúcia Cerávolo e Carlos Alberto Ferreira Martins pela força desde o início, sem vocês em São Carlos tudo ficaria mais difícil.

A Luciana, J oão Paulo, Gabriela, J oão Vitor, Guilherme e Luiza por me darem o apoio e a descontração de família.

Aos amigos importantes neste percurso, Carolina Margarido Moreira, Maristela Siolari, Fábio Abreu, Aline Cristina dos Santos Rios e Adele Cecília dos Santos Rios.

Aos funcionários e professores do Departamento de Arquitetura da Escola de Engenharia de São Carlos sempre solícitos e prestativos. 


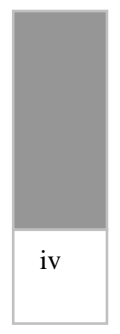




\section{SUMÁRIO}

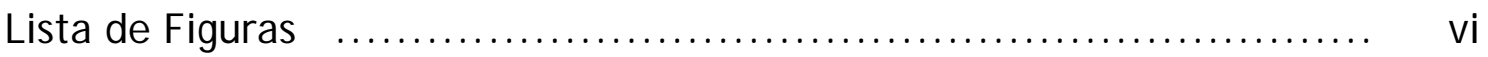

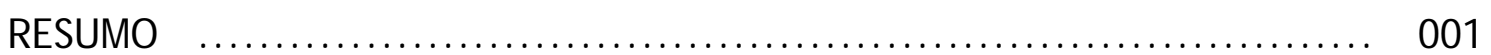

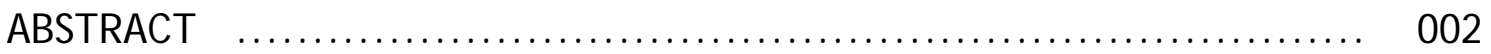

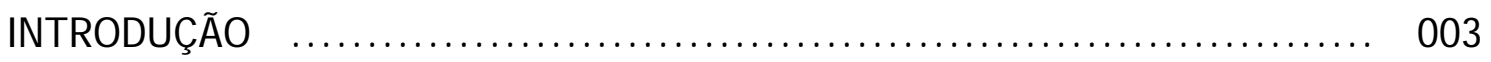

CAPÍTULO 1 Industrialização, Pré-fabricação e Arquitetura Moderna.... 009

CAPÍTULO 2 Movimento Moderno e Habitação Social no Brasil........... 033

CAPÍTULO 3 A CECAP e o Conjunto Habitacional Zezinho Magalhães Prado..................................................... 063

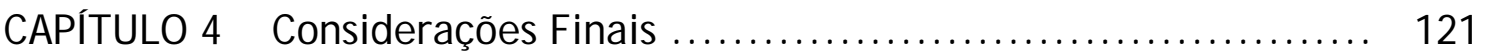

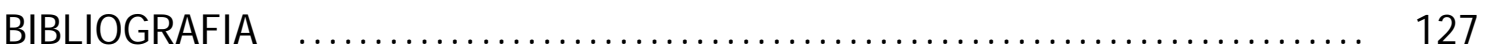

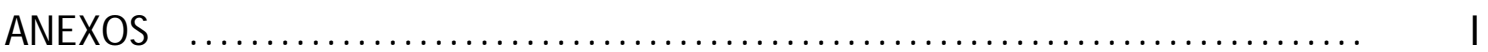




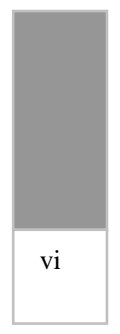


Capa - Croquis da parte interna da unidade habitacional, realizados por Artigas em 1967 - cedidos por Mário Savioli.

Figura 001 - Palácio de Cristal (1851) - J oseph Paxton.

Figura 002 - Salão de Leitura da Biblioteca Nacional de Paris (185868) - Henri Labrouste.

Figura 003 - La Città Nuova (1913-1914) - Antonio Sant'Elia.

Figura 004 - Fábrica de turbinas AEG (1908-1909) - Behrens.

Figura 005 - Fagus (1910) - Gropius e Alfeld na der Leine.

Figura 006 - Mercado de Peixe de Belém.

Figura 007 - Terceiro Pavilhão do Mercado de Manaus.

Figura 008 - Catálogo Casas Alladin.

Figura 009 - Catálogo Casas Sears.

Figura 010 - Westhausen - Plano de 1929. Ernest May

Figura 011 - Westhausen - Vista aérea em 1932. Ernest May

Figura 012 - Pedregulho - Reidy

Figura 013 - Crusp fachada sul c/ placas coloridas - Kneese de Mellho

Figura 014 - Crusp fachada sul original

Figura 015 - Foto aérea do Crusp incompleto

Figura 016 - Crusp - Pilotis

Figura 017 - Localização do Conj. Hab. Zez. Mag. Prado. 065

Figura 018 - Matrícula de 1.780.000m². 067

Figura 019 - Implantação de todas construções no Conjunto. 070

Figura 020 - Implantação do projeto de 1967 na malha urbana. 070

Figura 021 - Edifícios da primeira fase de construção. 071

Figura 022 - Vista da montagem pré-moldada. 077

Figura 023 - Espaço Interno entre os edifícios 2007.

Figura 024 - Espaço Interno entre os edifícios 1972.

Figura 025 - Lado externo dos edifícios da freguesia FF. 078 
Figura 026 - Planta da unidade habitacional 079

Figura 027 - Montagem da estrutura de madeira que sustenta o gesso 083

Figura 028 - Divisórias de gesso 083

Figura 029 - Fundação do tipo estaca, amarrada em bloco de concreto, base dos pilares 084

Figura 030 - Canteiro entre blocos

Figura 031 - Detalhe da parede hidráulica entre unidades habitacionais 085

Figura 032 - Cobertura de laje com argila expandida mantida coberta com água

Figura 033 - Localização da etapa 1

086

Figura 034 - Vista do bloco com escada em U 091

Figura 035 - Detalhe do pavimento tipo do bloco com escada em U 092

Figura 036 - Detalhe da escada em U, com duto de lixo e quadro de distribuição elétrica

Figura 037 - Fachada lateral, corte Iongitudinal e fachada frontal do bloco

Figura 038 - Fachada lateral e corte transversal

Figura 039 - Mesas de concreto - vigas

Figura 040 - Mesas - garagem

Figura 041 - Mesas de concreto cozinha - vigas

Figura 042 - Blocos de concreto - fachada

Figura 043 - Espaço interno entre blocos com caixa de escadas 095

Figura 044 - Espaço interno entre blocos

Figura 045 - Duto lixo e elétrico

Figura 046 - Fachada fundos

Figura 047 - Pingadeira original

Figura 048 - Pingadeira vazada

Figura 049 - Portaria condomínio São Paulo

Figura 050 - Caixilhos originais

Figura 051 - Canteiro entre blocos

Figura 052 - Hall do terceiro andar 
Figura 053 - Projeto fogão

$\begin{array}{ll}\text { Figura } 054 \text { - Projeto forno } & 101\end{array}$

Figura 055 - Proj eto geladeira 101

Figura 056 - Projeto máquina de lavar 101

Figura 057 - Projeto armário da área de serviço 102

Figura 058 - Projeto armário dos dormitórios 102

Figura 059 - Localização dos condomínios Santa Catarina, Paraná e 103 Rio Grande do Sul

Figura 060 - Vista do bloco com escada 105

Figura 061 - Detalhe do bloco com escada 105

Figura 062 - Portaria condomínio Rio de J aneiro 106

Figura 063 - Portaria condomínio Minas Gerais 106

Figura 064 - Caixa de escada 106

Figura 065 - Caixa de escada 106

Figura 066 - Fachada condomínio Rio de J aneiro 107

Figura 067 - Detalhe banco, lixo e caixa elétrica 107

$\begin{array}{ll}\text { Figura } 068 \text { - Detal he escada } & 107\end{array}$

Figura 069 - Piso térreo sob pilotis 107

Figura 070 - Pingadeira 108

Figura 071 - Caixilhos de alumínio e marcas das formas 108

Figura 072 - Localização dos condomínios Minas Gerais, Rio de 109 J aneiro, Bahia, Espírito Santo, Sergipe e Alagoas

Figura 073 - Vista lateral do bloco 110

Figura 074 - Vista do bloco com escada 111

Figura 075 - Detalhe do bloco com escada 111

Figura 076 - Vista da fase de construção 112

Figura 077 - Croquis da montagem da estrutura 112

Figura 078 - Corte do bloco com escada 112

Figura 079 - Vista entre blocos $\quad 113$

Figura 079A - Fachada com esquadria de alumínio 113 
Figura 080 - Vista posterior entre blocos

Figura 080A - Vista interna da unidade

113

Figura 081 - Garagem sob pilotis

Figura 082 - Detalhe da lixeira

Figura 083 - Centro de abastecimento do Parque CECAP

Figura 084 - Centro de Saúde

Figura 085 - Praça Mamonas Assassinas

Figura 086 - Campos de futebol 116

Figura 086A - EEPSG

Figura 087 - Complexo de escolas

Figura 088 Hospital Geral

Figura 089 Centro Comunitário

Figura 090 - Implantação do conj unto habitacional

Figura 090A - Implantação do conjunto habitacional

Figura 091 - Quadra entre blocos 120

Figura 092 - Cerca próxima aos blocos 
A pesquisa aqui efetuada tem por objetivo o estudo do Conjunto Habitacional Zezinho Magalhães Prado, interpretado como uma expressão dos objetivos modernos que buscavam, através da introdução de processos industriais na construção civil, resolver os problemas sociais, particularmente, a carência de moradias. Tais objetivos foram formulados na Europa após a I Guerra Mundial e aqui no Brasil conheceram uma perspectiva própria, dentre outras questões, justamente em função do atraso industrial do país. Os autores do projeto são os arquitetos Vilanova Artigas, Fábio Penteado e Paulo Mendes da Rocha. 0 projeto é tido como paradigmático da sua época em termos de concepções e inovações tecnológicas, algumas bem sucedidas, outras não. Através de entrevistas de profissionais envolvidos com o projeto e a obra do Conjunto e de material iconográfico e documental, o trabalho buscar contribuir para remontar uma parte da história que se perdeu com o fim do órgão que foi responsável pela sua construção, a CECAP (Caixa Estadual de Casas para o Povo).

Palavras-chave: habitação, arquitetura moderna, conjunto habitacional, préfabricação, Industrialização. 


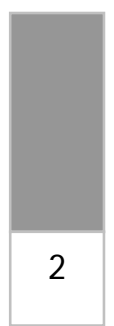


The paper here developed intends to study the housing project Zezinho Magalhães Prado, interpretated as an expression of the modern goals, searching to solve social problems, in particular the lack of habitation, through the introduction of industrial processes in construction. Those goals were formulated in Europe after the World Was I and here in Brazil a unique perspective was known by that time, among other questions, due to the country's industrial underdevelopment. The authors of the design project were Vilanova Artigas, Fábio Penteado and Paulo Mendes da Rocha. The project is known as a paradigm in terms of concept and technological innovations, some of which well succeeded, some of which, not as much. Over interviews with professionals involved to the design project and the construction of the housing project, and iconographic and documental material, this paper intends to contribute to the reconstruction of part of the history that got lost with the end of the public organ responsible for its construction, the CECAP (Caixa Estadual de Casas para o Povo).

Keywords: habitation, modern architecture, housing project, pre-built, industrialization 


\section{INTRODUÇÃO}

Este trabalho, denominado A Pré-Fabricação em Concreto Armado Aplicada a Conjuntos Habitacionais no Brasil: 0 caso do "Conjunto Habitacional Zezinho Magalhães Prado" tem como objetivo estudar, a partir de um entendimento dos ideais modernos, como se deu a transferência desses ideais, no quadro do desenvolvimento econômico e cultural do Brasil, particularmente a partir da década de 1930 até o final da década de 1960, quando é realizado o proj eto do Conjunto.

Como vários autores salientam, a pesquisa historiográfica é realizada em grande parte na busca e análise de documentações. Os fatos documentados, em geral são fatos passados, o documento é uma chave de leitura do passado. Entretanto, na arquitetura, o documento, por vezes, é uma edificação que permanece, está presente. Este é o caso do Conjunto Habitacional Zezinho Magalhães Prado. A sua presença evoca várias questões, principalmente àquelas que confrontam ideais e objetivos e a realidade como se dá. Mas também permite a verificação in loco de como a poética dos ideais se materializou fisicamente, com suas marcas e rastros.

Outra fonte de documentação preciosa que 0 trabalho pôde desenvolver, deu-se a partir dos relatos obtidos com vários profissionais que participaram do projeto e da obra. Com todos os problemas que o relato oral fornece, eles introduzem perspectivas novas que reforçam determinadas impressões, mas também, por outro lado, apresentam versões extremamente surpreendentes.

Há uma história pesquisada, analisada e interpretada, e há um Conjunto presente. O trabalho procurou um caminho difícil, 0 da análise técnica e o da investigação historiográfica. Há falhas e lacunas, mas acreditamos que haja uma contribuição importante para a compreensão de um episódio do modernismo brasileiro.

Com a pesquisa bibliográfica foi possível construir uma base para 0 entendimento da questão da industrialização da construção, questão chave do 
modernismo arquitetônico e do debate no Brasil, que depositava na indústria esperanças sociais e culturais.

Os conceitos que informam o trabalho foram sendo desenvolvidos a partir das precisões necessárias. Assim, a partir do título do trabalho tivemos que recorrer às definições de Pré-fabricação. Buscamos para tanto, uma definição objetiva retirada de Roberto Alves de Lima Montenegro Filho, para quem a pré-fabricação na construção civil pode ser entendida como "fabricação dos componentes antes da execução, no próprio canteiro ou fora, e que em uma fábrica a habilidade do artesão é substituída pelo uso da máquina". ${ }^{1}$

A fabricação colocava em evidência a industrialização da construção. Desta forma a conceituação de industrialização, ainda que corrente, necessitou ser interpretada e estabelecida. Para tanto, a formulação de Paulo Bruna nos pareceu a mais adequada, em função das questões que 0 modernismo estabeleceu (padronização de componentes, elementos, etc). Para Bruna "A industrialização trata-se de uma fase da pré-fabricação. Incorpora os métodos de produção em massa de elementos produzidos em grandes séries idênticas. Busca atender a uma alta demanda de maneira econômica. Deve ser entendida analisando-se de forma mais ampla as relações de produção envolvidas e a mecanização dos meios de produção" ${ }^{2}$.

Como veremos os dois conceitos citados, através dos seus termos (préfabricação e industrialização) permeiam o trabalho inteiro, mas não só eles. Quando se fala de pré-fabricação, ou de industrialização na arquitetura, estáse buscando uma racionalização, para não falarmos em arquitetura racional. Sem verificarmos o conteúdo mais amplo de arquitetura racional, que na verdade extrapola a discussão pertinente a arquitetura e atinge um conteúdo social amplo, o de um mundo guiado e organizado pela razão, fixamos nossa preocupação no entendimento da racionalização construtiva.

\footnotetext{
${ }^{1}$ MONTENEGRO FILHO, R.A. de L. (2007). Pré-fabricação e a obra de Eduardo Kneese de Mello. pg. 15.

2 BRUNA, P. J. V. (1976). Arquitetura, Industrialização e Desenvolvimento. pg. 19 a 21.
} 
Assim, localizamos na definição de Luiz Sérgio Franco, conceitos precisos para a orientação do trabalho. Para o autor "Racionalização construtiva é um processo composto pelo conjunto de todas as ações que tenham por objetivo otimizar o uso de recursos materiais, humanos, organizacionais, energéticos, tecnológicos, temporais e financeiros disponíveis na construção em todas as suas fases" ${ }^{3}$.

0 "conjunto de ações" e o "uso de recursos" indicam a próxima conceituação que procuramos verificar, a de sistema. Neste caso, ao contrário de uma definição específica buscamos uma ampla, fornecida pelo dicionário Filosófico - ludin e Rosental, que informa "Sistema: Conjunto de elementos, relacionados entre si, que constituem uma determinada formação íntegra."

A definição ampla é explicada em função da identificação, por parte de vários autores, de uma multiplicidade de sistemas construtivos, ainda vivos na construção e que se apresentam, mais ou menos claramente no trabalho.

Em relação ao processo construtivo, observamos a conceituação e classificação de Ricardo Martucci (1990), sendo processo construtivo definido pelas formas e as capacidades técnicas e econômicas de se construir, podendo ser classificado, de acordo com seu desenvolvimento tecnológico, em artesanal, tradicional, tradicional racionalizado, pré-fabricado e industrializado.

Para processo artesanal de produção, pensamos como apropriada a definição de Teodoro Rosso: "Método artesanal: pode ser definido como aquele que resulta da estratificação histórica das técnicas, regras e padrões que organizam a produção individual, realizada manualmente por ofícios" ${ }^{4}$.

Para a definição oposta, de processo industrial entendemos como pertinente que: é aquele que se utiliza de uma estratégia de fabricação que envolve os aspectos de interpretação do sistema, no que se refere ao desenho

\footnotetext{
${ }^{3}$ FRANCO e outros, B. A pré-fabricação no Conjunto Residencial da Universidade de São Paulo CRUSP.

${ }^{4}$ ROSSO, T. (1979). Racionalização das Construções. pg. 32.
} 
industrial, planejamento, programação e controle, adicionando-se engenharia de produção, engenharia de manutenção e administração industrial, visando sempre a facilidade na montagem final e os menores custos do produto acabado $(A B C I)^{5 \prime \prime}$

Para fins do trabalho, o processo convencional, ou tradicional é caracterizado por utilizar técnicas correntes, tradicionais, com alguma organização coletiva de trabalho. Os demais sistemas agrupam e articulam técnicas de estágios (sistemas) distintos. Estes sistemas mistos estavam muito presentes na realidade brasileira, na época do projeto e da obra do Conjunto. A articulação entre técnicas e métodos desiguais na produção é uma característica na indústria da construção local. Para muitos é um entrave, para outros um campo a ser explorado.

Por fim, mas não menos importante, e na medida da sua citação na última conceituação, ainda que permeiem toda a discussão, valemo-nos das definições de Ruy Gama para técnica e tecnologia. Segundo o autor, a primeira é 0: "conjunto de regras práticas para fazer coisas determinadas, envolvendo a habilidade do executor e transmitidas, verbalmente, pelo exemplo, no uso das mãos, dos instrumentos e ferramentas e das máquinas." 6 Já tecnologia é o: "estudo e conhecimento científico das operações técnicas ou da técnica. Compreende o estudo sistemático dos instrumentos, das ferramentas e das máquinas empregadas nos diversos ramos da técnica, dos gestos e dos tempos da trabalho e dos custos, dos materiais e da energia empregada" $^{7}$

A partir dessas definições cremos que podemos iniciar a discussão proposta. Outros conceitos aparecem ao longo dos capítulos. Nesses casos, mais ligados a aspectos culturais da arquitetura moderna e do desenvolvimento nacional, o que remete a complexidade de como os conceitos abstratos se relacionam com os acontecimentos sociais, complexidade da qual o Conjunto Habitacional Zezinho Magalhães Prado é um grande exemplo.

\footnotetext{
${ }^{5}$ Manual da $\mathrm{ABCl}$ (Associação Brasileira de Construção Industrializada.

${ }^{6}$ GAMA, R. (1986). Tecnologia e o Trabalho na História.

7 idem.
} 


\section{Industrialização, Pré-fabricação e Arquitetura Moderna.}

\section{A origem da industrialização da construção}

A partir do século XIX e até meados do século XX, foram feitas muitas inovações tecnológicas na construção civil européia e norte-americana, essas inovações, vistas com muita reserva pela maioria dos arquitetos, findou por ter 0 seu reconhecimento. Assim, realizaram-se projetos e obras transformando os parâmetros vigentes de beleza, de composição, de estilo arquitetônico, de técnica construtiva e de sua ligação com o espaço construído.

Com a Revolução Industrial, a arquitetura fabril e dos novos equipamentos, estações ferroviárias, as pontes, os galpões construídos, começou a rivalizar com a arquitetura tradicional. Os novos materiais empregados, particularmente o ferro combinado com 0 vidro para 0 fechamento das edificações, possibilitaram grandes vãos nas edificações e uma luminosidade inovadora para os interiores.

As obras funcionais que se valiam dos novos materiais e das novas possibilidades tecno-construtivas, ganharam uma nova dimensão quando da construção do Palácio de Cristal (figura 1) para a Exposição Mundial de 1851 em Londres: um imenso pavilhão de ferro e fechamento em vidro com 1851 pés ${ }^{1}$ de comprimento e 490 de largura.

Afora as inovações construtivas, o Palácio foi um grande sucesso de público, justamente em função da espacialidade que os vãos da estrutura metálica permitia, o que colocou em cheque o estatuto da arquitetura tradicional, fosse neo-clássica, ou outro estilo qualquer, que não fizesse uso,

\footnotetext{
${ }^{1} 1$ pés $=30,48 \mathrm{~cm}$. Portanto, $564 \mathrm{~m}$ de comprimento e $149 \mathrm{~m}$ de largura.
} 
ou se mostrasse aberta para as novas possibilidades construtivas. A evidência dessa postura fica expressa na observação de um político alemão Y. L. Bucher:

"El edificio no encontro oposition, y la impresión de quienes lo vieron fue de tanta romántica belleza que los grabados con reproducciones del Palacio llegaron hasta las granjas de lejanos pueblos alemanes. Considerando este primer edificio sin necesidad de sólida fábrica, los observadores no tardaron en comprender que las reglas por las que se juzgaba hasta entonces la arquitectura habían dejado de ser válidas." ${ }^{2}$

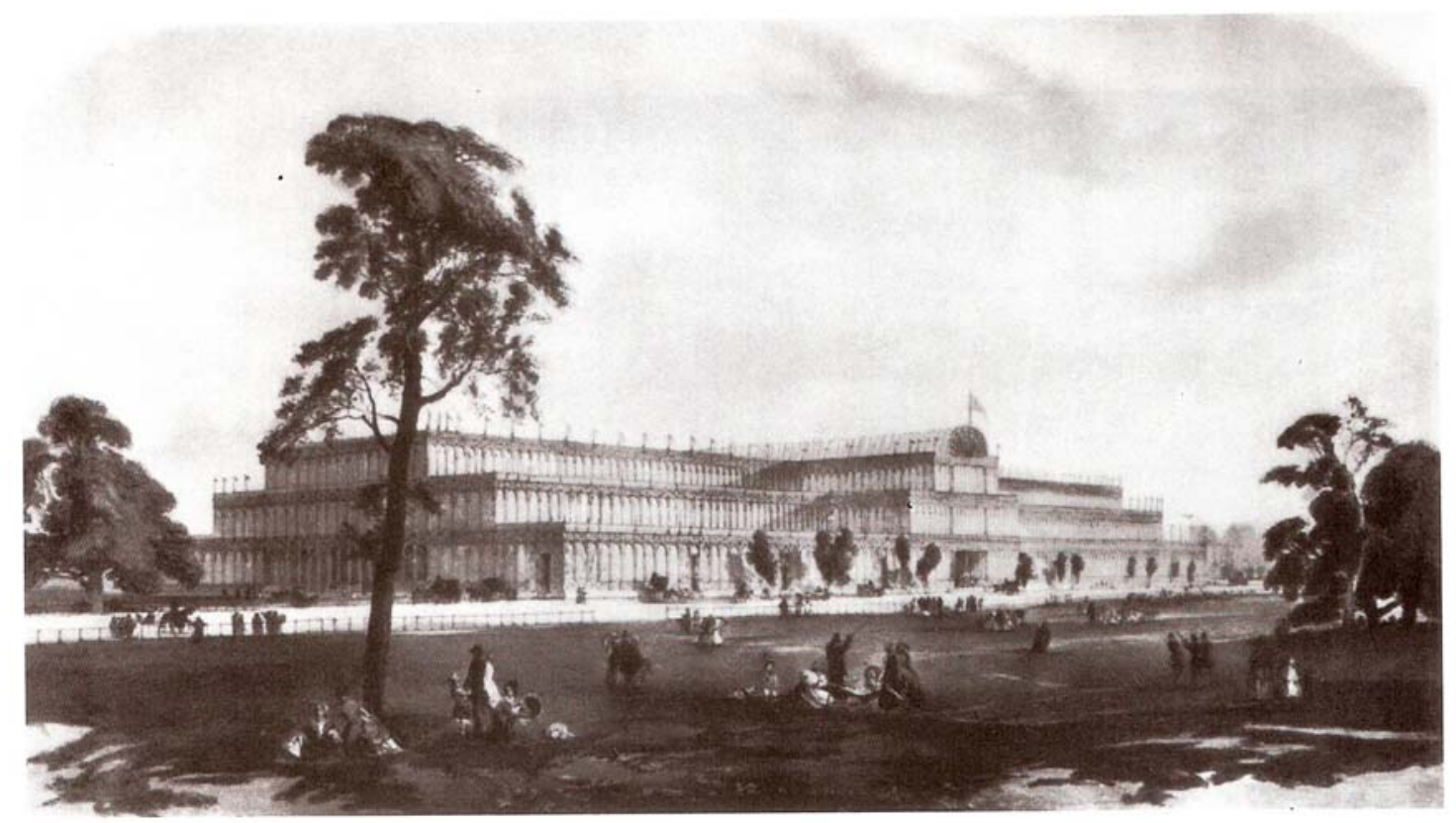

Figura 1 - Palácio de Cristal (1851) - J oseph Paxton;

Fonte: Giuglio Carlo Argan.

Na seqüência, outras Exposições mundiais como a de Paris em 1855, a de Viena 1863, a de Filadélfia de 1876, novamente a de Paris em 1878, dentre outras, reforçaram a tipologia do grande pavilhão de estrutura metálica e

\footnotetext{
${ }^{2}$ BENÉVOLO, L. (1989). Historia de la Arquitetctura Moderna. p. 136. A autoria do projeto do Palácio de Cristal é de J oseph Paxton, construtor de Estufas. Depois da exposição, a edificação foi desmontada. A obra além de defensores foi objeto de crítica profunda como as formuladas por J. Ruskin, no percurso de suas críticas sobre a perda de significado que as mudanças técnico-sociais estavam operando na arte.
} 
fechamento em vidro, popularizando ainda mais as novas possibilidades construtivas e a espacialidade decorrente. ${ }^{3}$

O impacto das novas possibilidades construtivas conheceu assim um desenvolvimento na arquitetura que extrapolou os edifícios fabris e das instalações ferroviários, sendo acompanhado de um debate que opunha adeptos da produção industrial nas artes e aqueles que viam nisso uma perda de qualidade inevitável, frente à produção artesanal.

Particularmente na Inglaterra, as discussões promovidas por J. Ruskin e as iniciativas de W. Morris caracterizam esse debate. A discussão é complexa e Ruskin por vezes é apresentado como passadista, o que talvez não seja preciso, e Morris no seu intuito de preservar o artesanato, mas ao mesmo tempo depurá-lo, abriu uma senda para a elaboração de uma nova concepção dos objetos, baseada numa linguagem limpa, sem adornos, que viria a ter uma comunicação com a arquitetura moderna, também pensada como depurada de ornamentos.

$\mathrm{Na}$ arquitetura, propriamente dita, destacamos os seguintes arquitetos que introduziram no fazer arquitetônico e, conseqüentemente, em suas obras a utilização dos novos materiais, no período compreendido entre meados do século XIX até o início do XX, antes da Primeira Guerra Mundial, foram eles:

- Henri Labrouste autor da Biblioteca de Saint-Geneviève (1843-1850) e da Biblioteca Nacional (figura 2) - inicialmente Imperial - (1858-1868), ambas em Paris. Labrouste, arquiteto de formação acadêmica, questionava as idéias convencionais de estilo, propugnando a busca de uma racionalidade que as construções com os novos materiais apresentavam; ${ }^{4}$

\footnotetext{
${ }^{3}$ Segundo Benévolo, depois de 1878 as exposições se multiplicam: Sydney (1879), Melbourne (1880), Amsterdan (1883), Amberes e Nova lorque (1885), Barcelona, Copenhague e Bruxelas (1888). Benévolo, L. op. cit p. 148.

${ }^{4}$ Benévolo caracteriza Labrouste como a maior expressão do racionalismo neoclássico e creditam suas concepções as elaborações anteriores de Durand. Ver Benévolo, L. op.cit. pp. 130-132.
} 


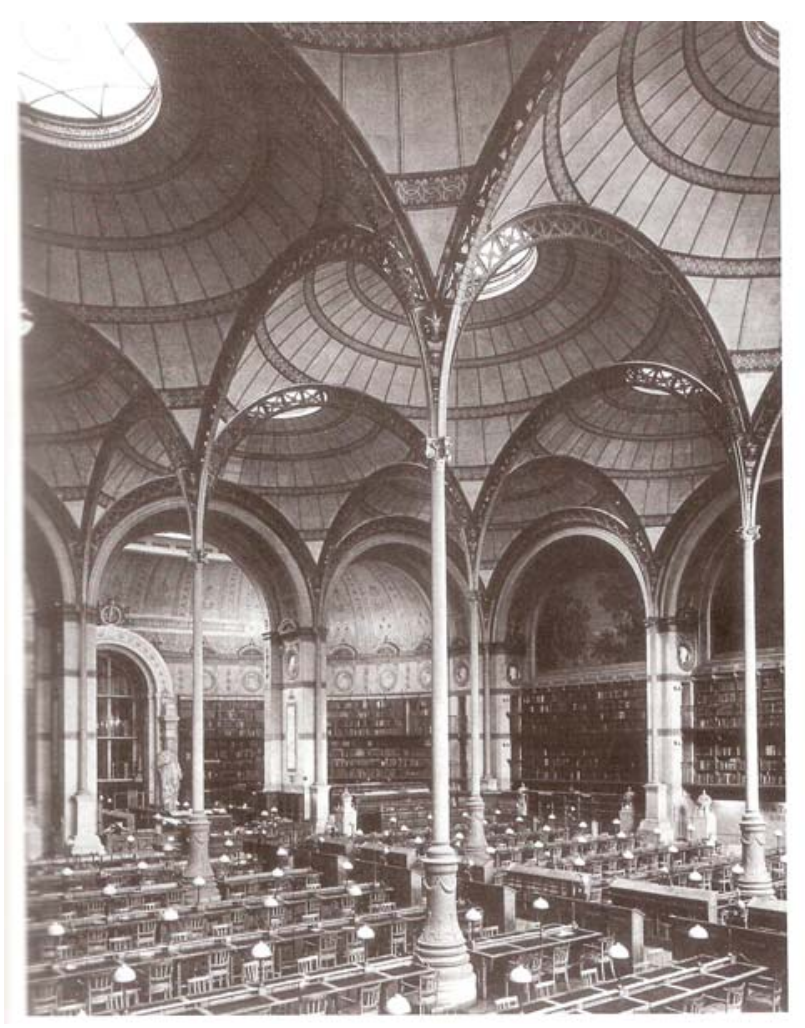

Figura 2 - Salão de Leitura da Biblioteca Nacional de Paris (1858-68) - Henri Labrouste;

Fonte: Giuglio Carlo Argan.

- Sem dúvida uma das maiores personalidades do debate arquitetônico e das conseqüências para a arquitetura dos novos materiais e das novas técnicas construtivas foi Viollet le Duc. As discussões na França e na Inglaterra na segunda metade do século XIX entre adeptos do Neogótico e adeptos do neo-clássico por vezes parecem abstratas, mas devem ser interpretadas como a maneira pela qual era enfrentada as inovações tecnológicas, buscando alguma referência na arquitetura e sua história. Le Duc, que criticava a opção pelo neo-clássico por parte da Academia Francesa e surgia como defensor do gótico por ser um estilo mais apropriado a determinadas regiões deve ser interpretado, como propõe Frampton, a partir de seus escritos: 
“Em arquitetura, há dois modos necessários de ser autêntico. Pode-se ser autêntico de acordo com o programa e autêntico de acordo com os métodos de construção. Ser autêntico de acordo com o programa é cumprir exata e simplesmente as condições impostas pela necessidade; ser verdadeiro de acordo com os métodos de construção é empregar os materiais de acordo com suas qualidades e propriedades. (...) As questões puramente artísticas de simetria e forma aparente são apenas condições secundárias na presença de nossos princípios dominantes". ${ }^{5}$

- As posições de le Duc influenciaram arquitetos como Gaudi, cujas obras expressivas, dentre outras, a Igreja da Sagrada Família, o Parque Guel e a Casa Milà (todas em Barcelona), evocam uma plasticidade exuberante e um esmero técnico profundo, aliados a um sentido de localidade que os materiais revelam; Horta, que dentre várias obras de extração art-nouveau, destaca-se a Maison du Peuple (1897-1900), genericamente pela singularidade de sua forma, no exterior pelo uso do tijolo aparente e modulado em relação à pedra e no interior pela utilização de estrutura metálica permitindo uma liberdade espacial inovadora e Berlage que com o edifício da Bolsa de Amsterdan (18971903) realizou segundo Frampton uma obra em sintonia com os princípios do racionalismo estrutural preconizado por le Duc;

- A esses arquitetos (e suas obras) somam-se outros que se colocaram a questão de compatibilização dos preceitos arquitetônicos históricos, com os novos materiais, as novas possibilidades construtivas e os novos equipamentos (e seus novos programas) que a sociedade industrial e a

\footnotetext{
${ }^{5}$ VIOLLET-LE-DUC, E., Entreténs sur l'architecture (conversações sobre a arquitetura), In: FRAMPTON, K. (1997). História crítica da Arquitetura Moderna, p. 69. Há uma polêmica sobre o lugar e a importância de le Duc e suas idéias entre os vários autores da arquitetura moderna. Para Banham, as idéias de le Duc sobre a potencialidade do gótico em utilizar as máximas propriedades dos materiais são fortemente questionadas. Claro está que Banham defende uma origem moderna a partir das propostas de Guadet em oposição a uma linhagem que iria de le Duc a Choisy, perpassando Gaudi e o art-nouveau. Para esta discussão, além de Frampton, ver Banham, Reyner, Teoria e proj eto na Primeira Era da Máquina.
} 
cidade moderna solicitavam. Mackintosh, na Escócia, Wagner, Olbrich e Hoffmann na Viena da virada do século XIX para o XX, Sant'Elia (figura 3) e suas especulações futuristas da cidade industrial, que prefiguravam uma ruptura com a cidade histórica, Loos, também em Viena, questionando a aplicação de ornamentos nas edificações, Van de Velde, discutindo a abstração formal, tão cara ao modernismo, Tony Garnier, e a cidade industrial e Perret, projetando no sentido da evolução do Racionalismo Clássico (numa posição distinta daquela de le Duc), introduzindo de forma clara a estrutura de concreto em edificações de multi-piso na cidade (como no edifício 25 bis, na rue Franklin, Paris), todos eles, em que pesem diferenças, forjaram um arcabouço de concepções que os arquitetos que produziram após a primeira guerra iriam utilizar como referência;

- Essa breve digressão sobre o assunto não seria completa sem duas produções. Primeiro, a dos arquitetos norte-americanos e seus arranhacéus. Para eles utilizamos simbolicamente como referência o edifício Guaranty, erguido em Buffalo em 1895, de autoria de Adler e Sullivan. Com treze andares sintetiza a linhagem de arranha-céus norteamericanos de estrutura metálica independente e gabarito alto possibilitado pelo uso do elevador, que revolucionou a dimensão vertical dos edifícios. Segundo, a produção dos arquitetos alemães que desde a Deutsche Werkbund problematizaram a continuidade da produção artesanal, sua inviabilidade econômica frente à produção industrial e como adequar qualidade e uma linguagem própria a esta produção. Vários dos seus membros eram arquitetos e dentre eles alguns como Behrens e na geração seguinte Gropius, produziram edifícios fabris paradigmáticos da arquitetura moderna, como a fábrica de turbinas AEG de Behrens (figura 4), em Berlin (1908-1909) e a fábrica Fagus (figura 5) de Gropius e Meyer, em Alfeld-na-der-Leine (1911). 


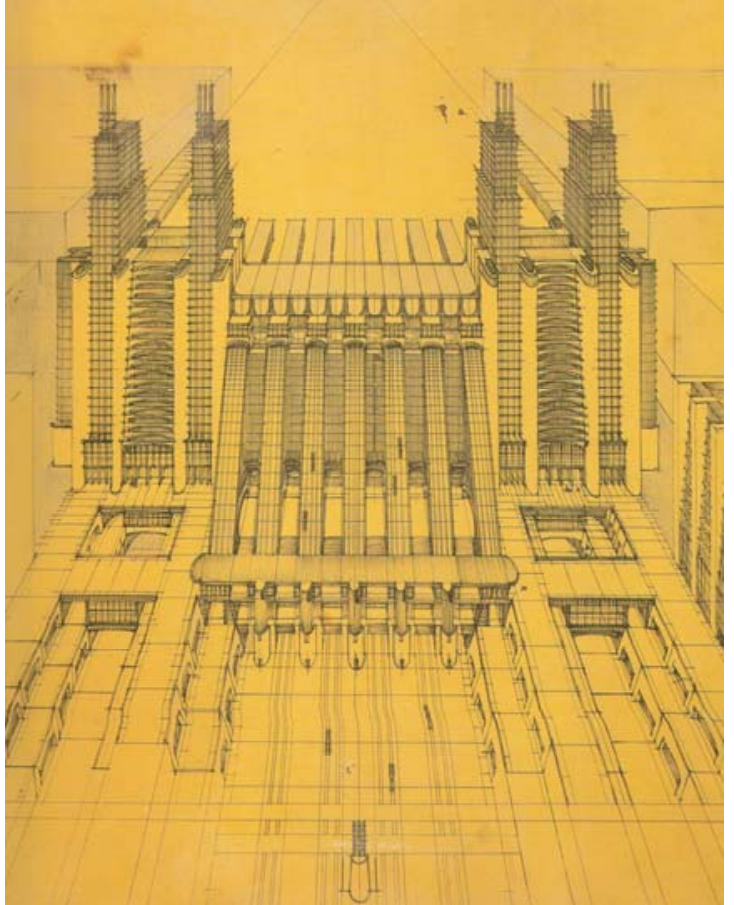

Figura 3 - La Città Nuova (1913-1914) Antonio Sant'Elia;

Fonte: Estilo Internacional (Taschen).

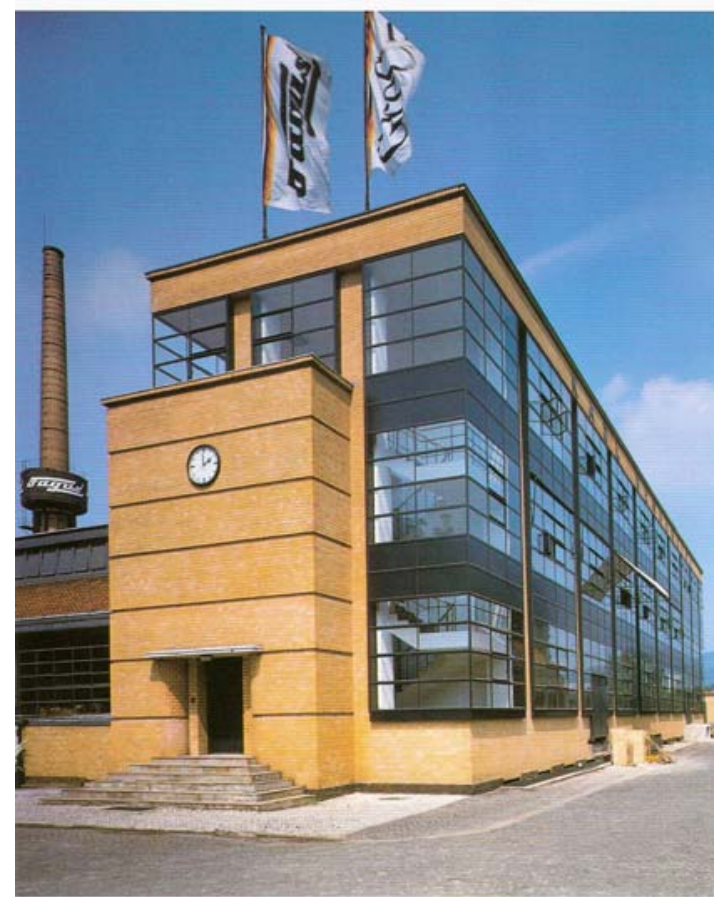

Figura 5 - Fagus (1910) - Walter Gropius e Alfeld na der Leine;

Fonte: Estilo Internacional (Taschen).

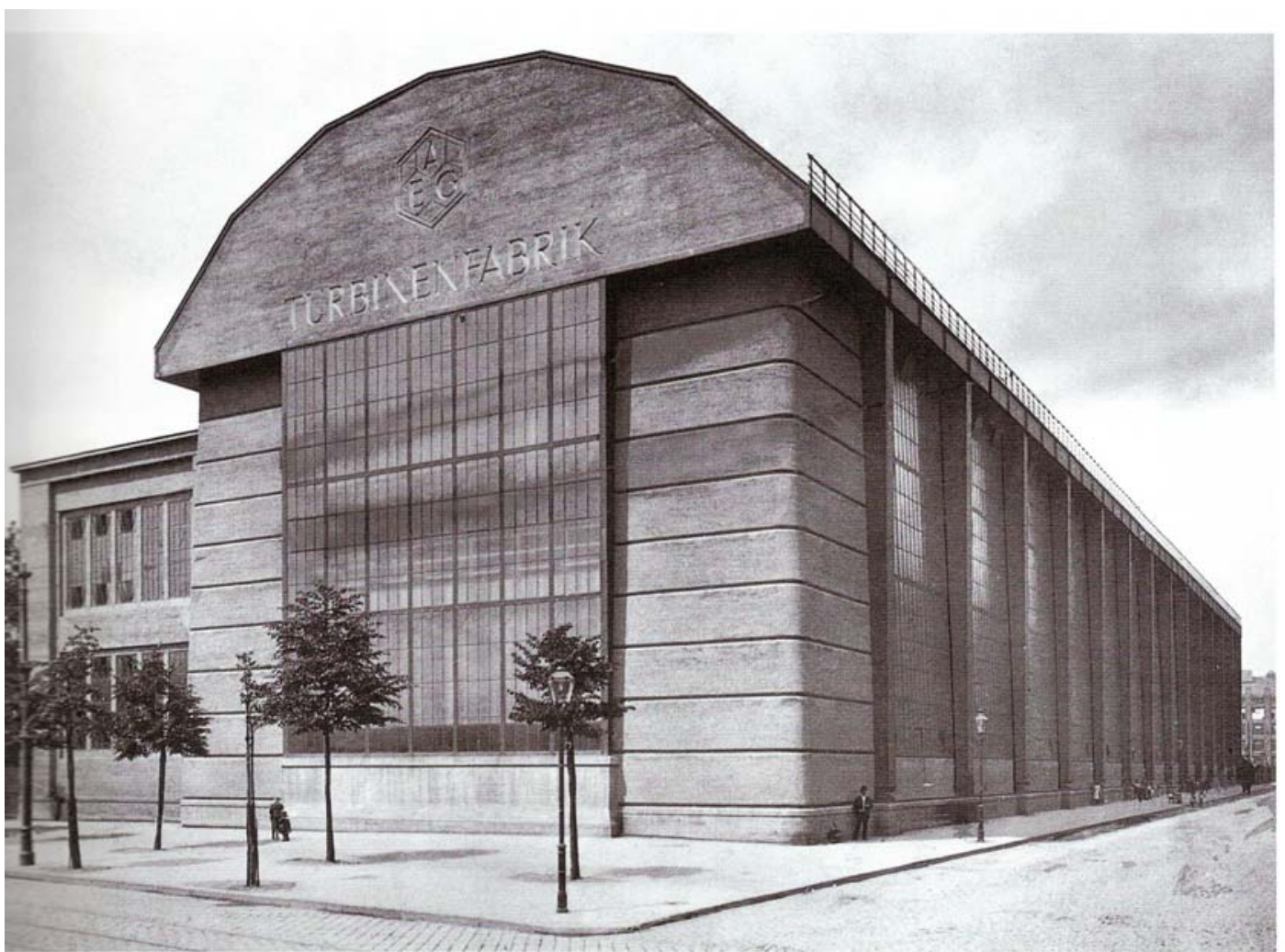

Figura 4 - Fábrica de turbinas AEG (1908-1909) - Peter Behrens; Fonte: Estilo Internacional (Taschen). 
Entretanto, até a Primeira Guerra Mundial, as discussões e propostas renovadoras de arquitetura, com exceção daquelas que abordavam a cidade moderna como um todo, ou seja, a cidade industrial, não colocavam na sua pauta a questão da habitação e principalmente a questão da habitação para atender ao grande contingente de trabalhadores que migravam do campo para a cidade.

Além disso, ainda que a racionalidade da produção estivesse presente na fabricação de componentes metálicos das estruturas e outros, a noção de uma arquitetura baseada em elementos pré-fabricados, com o objetivo de atender uma demanda massiva, e que se colocasse como possibilidade a estandardização, não fora desenvolvida.

Esta questão conheceu um desenvolvimento específico com as experiências norte-americanas, de certa forma, pouco conhecidas entre nós. Elas ganham um destaque, por estabelecerem-se com base na industrialização e na pré-fabricação de elementos, pelo volume produzido e pela forma como se deu, a partir da iniciativa privada.

Desde 1833, desenvolveu-se em Chicago, a técnica construtiva "ballon frame", sendo até hoje a principal tecnologia de construção de casa dos EUA, Norte da Europa, Austrália e Japão ${ }^{6}$. Esse sistema vale-se a racionalidade construtiva através da industrialização dos componentes modulares ${ }^{7}$.

\footnotetext{
"Trata-se de uma estrutura em que não existe a costumeira hierarquia de elementos principais e secundários, ligados através de encaixes, mas onde numerosas tiras finas de dimensões uniformes são colocadas em distâncias modulares e unidas por simples rebites; as aberturas, portas e janelas, são necessariamente múltiplos do módulo fundamental $(\ldots) .^{\prime \prime}$
}

\footnotetext{
${ }^{6}$ DAVIES (2005) apud MONTENEGRO FILHO, R. A. de L. (2007). MONTENEGRO FILHO, R. A. de L. (2007). Pré-fabricação e a obra de Eduardo Kneese de Mello. Dissertação (Mestrado) FAU/ USP. p. 17.

${ }^{7}$ MONTENEGRO FILHO, R. A. de L.(2007). Pré-fabricação e a obra de Eduardo Kneese de Mello. Dissertação (Mestrado) FAU/ USP. p. $17 / 18$
} 
A explicação de Leonardo Benévolo é preciosa, pois o sistema baseia-se em uma autonomia própria da produção industrial, que questiona os valores históricos na arquitetura. Podemos falar que há uma realidade produtiva que embute uma outra arquitetura, que a bem da verdade não foi explorado naquele momento. Seus idealizadores preferiram realizar uma arquitetura baseada em citações históricas, ou em um pastiche histórico.

Esse sistema de vigas padronizadas logo se espalhou por todo país, transformando os Estados Unidos como o maior centro produtor de casas préfabricadas. ${ }^{9}$ No século XIX, na Inglaterra, desenvolvia-se e difundia-se a préfabricação de componentes e de edificações inteiras, produção destinada ao mercado interno e para a exportação às colônias, tais quais, faróis, igrejas de ferro fundido, estradas de ferro, armazéns, etc. E para o Brasil, não foi diferente, temos muitos exemplos dessas construções, tais como o Mercado de Peixe, em Belém (figura 06) ou o terceiro pavilhão do Mercado de Manaus (figura 07).

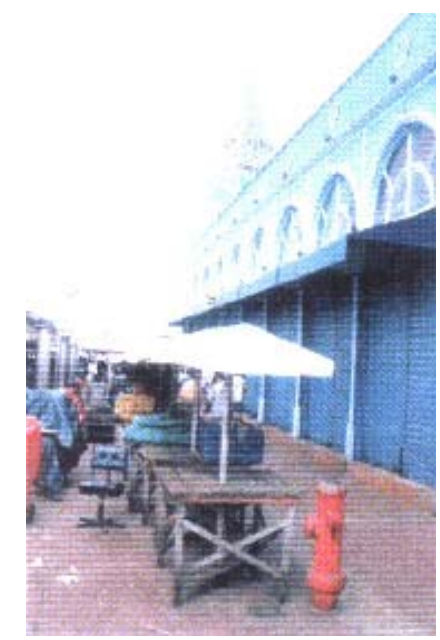

Figura 6 - Mercado de Peixe de Belém.

Fonte: Montenegro Filho.

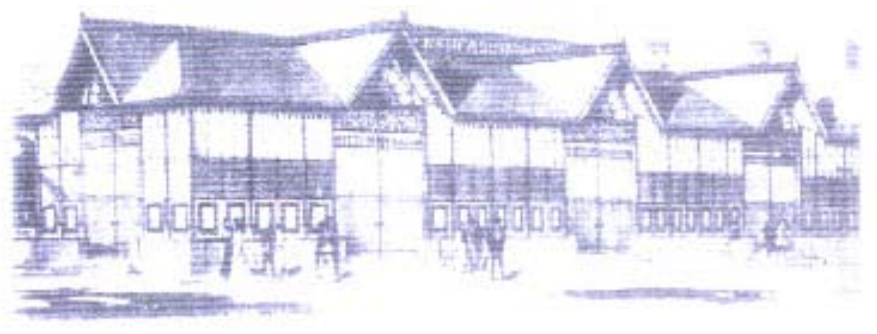

Figura 7 - Terceiro Pavilhão do Mercado de Manaus. Fonte: Kurl.

\footnotetext{
${ }^{8}$ BENÉVOLO, L. (1989). Historia de la Arquitetctura Moderna. p. 233.

9 MONTENEGRO FILHO, R. A. de L. (2007). Pré-fabricação e a obra de Eduardo Kneese de Mello. Dissertação (Mestrado) FAU/ USP. p. 19.
} 
“De um modo geral, essa pré-fabricação importada durante o século XIX e primórdios do século XX, foi empregada para atender a uma demanda de construções em um curto período, suprindo a carência de tecnologias e de mão-de-obra qualificada no país - como grandes vãos de coberturas de estações de trem e galpões de estocagem -, ou para atender a uma europeização desejada do ambiente urbano brasileiro teatros, mercados, chafarizes, coretos, gradis, etc." 10

Nos Estados Unidos, com um papel significativo da sociedade norteamericana, foi possível um maior desenvolvimento da pré-fabricação. Em 1906, a empresa americana Alladin Ready Cut foi a primeira a oferecer um kit de uma casa com peças pré-cortadas e numeradas. A empresa teve duração até 1981 com uma reprodução de 65.000 exemplares ready-cut ${ }^{11}$ (figura 08). A companhia de mais sucesso na época porém, foi a Sears Roebuck of Newark (figura 09), com vinte e dois modelas variando entre U\$650 e U\$250012. A aceitação era grande, pois as casas mantinham o estilo tradicional americano, não se diferenciando do todo. Entre 1908 e 1940 foram comercializadas aproximandamente 100.000 unidades que tinham em média o preço da mãode-obra $40 \%$ a menos do que no modo tradicional. ${ }^{13}$
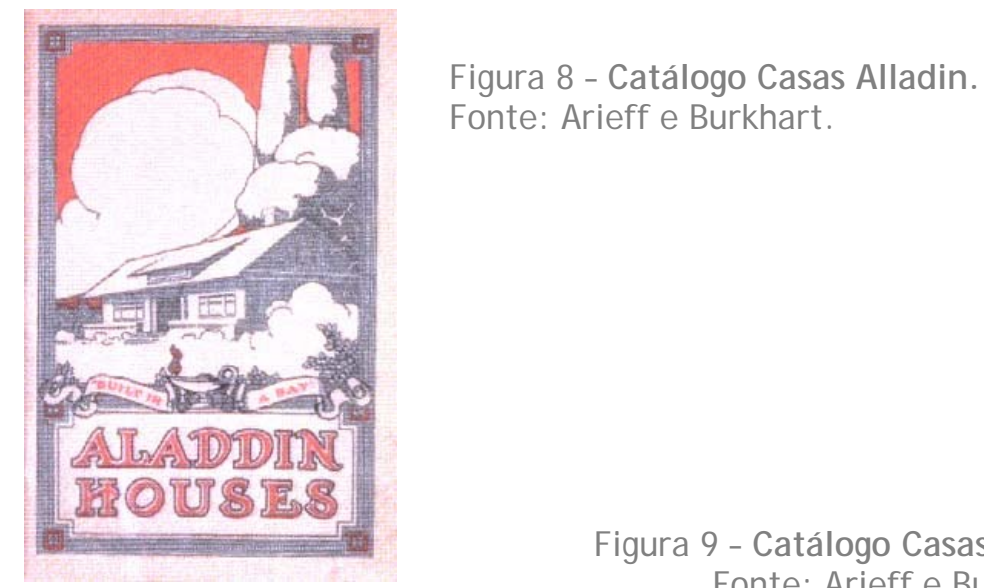

\section{Fonte: Arieff e Burkhart.}

Figura 9 - Catálogo Casas Sears. Fonte: Arieff e Burkhart.

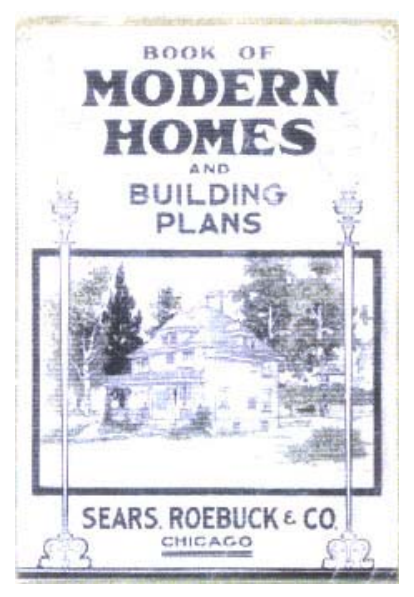

\footnotetext{
10 MONTENEGRO FILHO, R. A. de L.(2007). Pré-fabricação e a obra de Eduardo Kneese de Mello. Dissertação (Mestrado) FAU/ USP. p. 21.

${ }^{11}$ ARIEFF E BURKHURT (2002), . apud MONTENEGRO FILHO, R. A. de L. (2007). p. 22

12 DAVIES (2005) apud MONTENEGRO FILHO, R. A. de L.(2007). p. 22.

${ }^{13}$ ARIEFF E BURKHURT (2002) apud MONTENEGRO FILHO, R. A. de L.(2007). p. 22.
} 


\section{Industrialização pós Primeira Guerra}

A situação vivida na Europa iria mudar drasticamente após a Primeira Guerra Mundial, em termos políticos, sociais e econômicos. Frente a essa situação começou-se a delinear o posicionamento de vários arquitetos, artistas e intelectuais em relação às possibilidades da produção industrial, a racionalidade que ela incorpora, e que poderia ser traduzida em uma racionalidade técnico-científica para solucionar os problemas da sociedade e imprimir-Ihe um rumo positivo.

Para Manfredo Tafuri, este momento é fundamental, pois, a partir das iniciativas tomadas pode-se falar claramente de uma vanguarda histórica, que altera a visão em relação à indústria e sua produção. Ela passa a ser positiva e, portanto, é papel dos arquitetos e daqueles que participam do mundo da construção se assenhorear da tecnologia industrial em todas as dimensões que interferem na construção. As pesquisas se desenvolveram em torno de uma racionalização da construção com a intenção de produzir mais rapidamente edificações em grande quantidade e mais econômicas (que o exemplo americano evidenciava), para atender a uma demanda crescente decorrente do conflito mundial, sendo o combate ao déficit habitacional colocado como objetivo principal.

Em 1919, surge a Bauhaus em Weimar, dirigida por Gropius até 1928, e logo depois, sob sua influência, o movimento da construção habitacional nas cidades, com sua forte tendência social. Mais tarde o movimento foi apoiado em grande escala também por autoridades públicas. ${ }^{14}$

No I Congresso Internacional de Arquitetura Moderna (CIAM - 1928), realizado no Castelo de Sarraz, os arquitetos afirmavam:

\footnotetext{
${ }^{14}$ GROPIUS, W. (1972). Bauhaus: Nova Arquitetura, p. 105.
} 
“1. A idéia de arquitetura moderna inclui o vínculo entre o fenômeno da arquitetura e do sistema econômico geral.

2. a idéia de "eficiência econômica" não implica a oferta por parte da produção, de um lucro comercial máximo, mas a exigência, por parte da produção, de um mínimo esforço funcional.

3. a necessidade de uma eficiência econômica máxima é o resultado inevitável do empobrecimento da economia geral.

4. O método mais eficiente da produção é o que decorre da racionalização e da padronização. A racionalização e a padronização agem diretamente sobre os métodos de trabalho, tanto na arquitetura moderna (concepção) quanto na indústria da construção (realização).

5. A racionalização e a padronização agem de três modos diversos:

a) exigem da arquitetura concepções que levem à simplificação dos métodos de trabalho no lugar e na fábrica;

b) significam para as construtoras uma redução de mão de obra especializada; levam ao uso de uma mão de obra menos especializada que trabalhe sob a direção de técnicos da mais alta habilitação;

c) esperam do consumidor (ou seja, do consumidor que encomenda a casa na qual vai viver) uma revisão de suas exigências em termos de uma readaptação às novas condições da vida social. Essa revisão irá manifestar-se na redução de certas necessidades individuais, doravante desprovidas de uma verdadeira justificativa; as vantagens dessa redução irão estimular a máxima satisfação das necessidades da maioria, as quais se acham no momento restringidas ${ }^{15}$."

Essa declaração, fundamental para o Movimento de Arquitetura Moderna, assinada por 24 arquitetos, enfatiza a construção como atividade elementar do homem. Ela projeta a construção com um significado amplo, como veremos adiante.

\footnotetext{
${ }^{15}$ Declaração de La Sarraz, CIAM, 1928; In: FRAMPTON, K. (1997). História crítica da arquitetura moderna, p. 327.
} 
Nos CIAM em geral, a preferência formal pela regularidade é o prérequisito para aumentar a produção de casas, rumo à industrialização. Abaixo a síntese das duas primeiras fases dos CIAM, que importam para o foco deste trabalho:

1) 1928 -1933: compreendeu o congresso de 1929 Frankfurt e de 1930 Bruxelas; a mais doutrinária; dominados por arquitetos alemães de tendência socialista; o primeiro voltou-se para os padrões mínimos de vida e o segundo para as questões de altura ideal e dos espaços entre os blocos;

2) 1933 - 1947: A cidade funcional; foi dominado por Le Corbusier que fez predominar o planejamento urbano; surgiram artigos como a Carta de Atenas, a bordo do S. S. Patris; ${ }^{16}$

As formulações da Arquitetura Moderna e da modernização das cidades, se dariam com base nos novos conceitos idealizados nos CIAM, nos quais 0 conceito de moradia passa a estar relacionado com um novo tipo de homem emergente em função da sociedade possibilitada pelo desenvolvimento industrial e integrada à cidade. As propostas não se limitaram à questão construtiva, mas a ligavam a novas concepções de sociedade.

A definição de Anatole Kopp traduz claramente o espírito da época que guiava os arquitetos modernos, o conteúdo social que animava a prática desses profissionais:

\footnotetext{
${ }^{16}$ Há uma terceira fase que escapa às questões desse trabalho, a saber: de 1947 - 1956: No IX Congresso em Aix-enProvence França, em 1953; O TEAM X, formado pelos então jovens arquitetos, tendo à frente Alison e Peter Smithson e Aldo Van Eyck, protagonizou o rompimento total com os ideais do CIAM, ao qualificar as quatro categorias funcionalistas da Carta de Atenas: moradia, trabalho, lazer e esporte como abstratas, dirigindo as investigações urbanas para outras questões.
} 
"A arquitetura moderna não era apenas formas depuradas e técnicas contemporâneas, mas também e, sobretudo, a tentativa de participar, ao nível da construção do ambiente, na transformação da sociedade." 17

A idéia de construção se forjou com um sentido material e social, ou seja, a técnica que auxilia, ou que constrói um novo mundo. Nesta chave a idéia de construção se aliou à noção de montagem, que sintetiza os processos industriais e que foi transferida para as edificações. A forma da edificação deveria refletir os processos industriais, ou a marca da indústria. Refletir a pré-fabricação dos elementos era, portanto, uma qualidade arquitetônica:

"Os CIAM afirmaram, de modo explícito, que a arquitetura estava inevitavelmente sujeita às necessidades mais amplas da política e da economia, e que, longe de estar distante das realidades do mundo industrializado, teria que depender, em termos de seu nível geral de qualidade, não do trabalho artesanal, mas da adoção universal de métodos racionais de produção ${ }^{18 "}$.

Para Gropius:

"Cresce o entendimento de que uma viva vontade de configuração enraizada no conjunto da sociedade e da vida, abrangendo todos os campos de configuração humana para um objetivo unificador - começa e termina na construção. A conseqüência desse espírito transformado e aprofundado, e de seus novos meios técnicos, é uma forma construtiva transformada, que não resulta de sua própria vontade, mas que brota da essência da construção, da função que ela deve preencher (...) Os mestres construtores desse livro respondem afirmativamente ao 
mundo atual das máquinas e aviões e à sua velocidade. Eles aspiram a meios de configuração cada vez mais ousados para, suspensos no efeito e no fenômeno, superarem o torpor do mundo". ${ }^{19}$

Neste contexto, Le Corbusier propôs a Casa Dominó e a “Casa Máquina de Morar", relacionadas com a produção em série de casas segundo os moldes fordistas. Em Por uma arquitetura, Le Corbusier já expunha claramente que "o problema da casa não está colocado" de forma clara, e contrapondo com "o avião que é um produto de seleção natural", e que "a mecânica traz consigo o fator de economia que seleciona", portanto, assumir o universo maquínico, seria o caminho para equacionar o problema da moradia, daí propor "a casa é uma máquina de morar". No caso do avião o problema estava claro, o que certamente proporcionou uma solução mais rápida e precisa. Mas o pensamento moderno de Le Corbusier nos mostra claramente o que é uma concepção de alojamento para aquele momento, que deveria se pautar pelo necessário e lógico. Desta maneira coloca o problema:

\footnotetext{
"Uma casa: um abrigo contra o calor, o frio, a chuva, os ladrões, os indiscretos. Um receptáculo de luz e de sol. Um certo número de compartimentos destinados à cozinha, ao trabalho e a vida íntima.

Um quarto: uma superfície para circular livremente, um leito de repouso para se estender, uma cadeira para estar à vontade e trabalhar, uma mesa para trabalhar, estantes para arrumar rápido cada coisa em seu "right place".

Quantos cômodos: um para cozinhar, um para comer, um para trabalhar, um para se lavar e um para dormir. Tais são os padrões do alojamento $(. . .)^{20 " \prime}$.
}

\footnotetext{
${ }^{19}$ Walter Gropius, A Arquitetura Internacional 1925, livro baseado na I Exposição dos Produtos da Bauhaus com projetos de arquitetos de fora da instituição (inclusive estrangeiros).

${ }^{20}$ LE CORBUSIER. (2004). Por uma arquitetura, tradução Ubirajara Rebouças. p. 75.
} 
Le Corbusier, ainda no mesmo livro, faz a comparação com o carro (1921), mesmo ano que da concepção projetual das casas em série Citrohan, abaixo está um trecho desenvolvido por ele:

“(...) Se o problema da habitação do apartamento fosse estudado como um chassis, veríamos nossas casas se transformarem, melhorarem rapidamente. Se as casas fossem construídas industrialmente, em série, como os chassis, veríamos surgir rapidamente formas inesperadas, porém sadias, justificáveis e a estética se formularia com uma precisão surpreendente $(\ldots)^{\prime 21}$.

Walter Gropius, em Nova Arquitetura, expõe sua visão sobre as habitações mínimas, que complementa as idéias iniciais de Corbusier:

"O desejo de reproduzir uma boa forma Standard parece ser uma função da sociedade humana, o já o era bem antes da Revolução Industrial. (...) Nossas futuras casas não serão necessariamente produtos estereotipados como conseqüência da padronização e da préfabricação; a competição natural, no mercado livre, cuidará para que as partes de construção pré-fabricadas apresentem uma multiformidade tão individual quanto os artigos de consumo produzidos pela máquina, que hoje dominam o mercado". ${ }^{22}$

Ainda autores importantes como o próprio Gropius, tentariam elaborar uma explicação importante para a falta de desenvolvimento no setor da construção civil.

"O processo de industrialização apenas parece desenvolver-se mais lentamente na indústria de construção do que em outros setores da produção, pois o processo da construção é bem mais complexo. Uma

\footnotetext{
${ }^{21}$ Idem, p. 88.

${ }^{22}$ GROPIUS, W. (1972); Bauhaus: Nova Arquitetura. p. 119.
} 
após outra as partes da construção são retiradas da mão do artesão e entregue à máquina. Basta observar os catálogos dos fabricantes de material da construção para nos convencermos de que já existem inúmeros elementos de construção industrializados, à nossa disposição no mercado. Em um processo que se desenvolve continuamente, 0 antigo método artesanal está se transformando em processo de montagem de seções pré-fabricadas, produzidas industrialmente, e que são enviadas diretamente da fábrica ao canteiro de obras". ${ }^{23}$

Era preciso limpar os espíritos, Le Corbusier afirmava que a grande aquisição da arquitetura moderna era a reta, que seria a base da economia da habitação. Através do livro Por uma Arquitetura, tem-se a evolução de pensamento de Le Corbusier e a partir de 1924 com Pierre J eanneret, através de algumas obras extremamente importantes no contexto da racionalização e industrialização, são elas: Casa Dominó (1915), Casas em série Citrohan (1921), Pessac, bairros modernos (1924), Casa de Bourdeaux (1925), entre outras.

Todo esse histórico foi colocado como base de entendimento para a discussão feita nos CIAM. Os Congressos de Arquitetura que aconteceram até a Segunda Guerra Mundial, englobando tanto as fases germânica e francesa, colocaram a habitação e o novo urbanismo no centro de suas preocupações. Símbolo da ligação entre estas duas fases foi, sobretudo, o artigo de Le Corbusier e Pierre Jeanneret, no II CIAM, Frankfurt - 1929, que abordava questões sobre a revolução no processo construtivo para que se realizasse a "moradia mínima", através da simplicidade e dos princípios de estandardização, industrialização e taylorização, informando assim uma nova arquitetura e um novo papel para as artes. Na mesma linha, Ernest May diretamente vinculado à organização do congresso e arquiteto responsável pela implantação do programa das Neues Frankfurt, da municipalidade desta cidade, afirmava:

\footnotetext{
${ }^{23}$ GROPIUS, W. (1972); Bauhaus: Nova Arquitetura. p. 123.
} 
“(...) necessitamos viviendas suficientes em número y em calidad, que satisfagan las necessidades de las massas, de los que buscan viviendas com pocos medios. Necessitamos vivienda para el minimo de vida" ${ }^{24}$

A racionalização da construção deveria ocorrer utilizando novos materiais como o ferro e o concreto armado, associados ao vidro, redimensionando a sua presença na arquitetura. Evidentemente, a conversão de métodos industriais para a construção civil não foi imediata, o que por vezes levava a não realização plena do barateamento dos custos através da produção em série que se iniciava.

A produção social "Neues Frankfurt", era parte de um programa de intervenção urbana para o município de Frankfurt, que durante o período de 1926 a 1930 possibilitou a produção de habitação para 10\% da população e, em termos urbanos, implementou: a criação de uma zona industrial ao longo do rio Main, servida por vias férreas, a criação de equipamentos culturais e institucionais no centro, a manutenção de um baixo adensamento na área central e uma urbanização da região periférica com o desenvolvimento de siedlungs (colônias) e cidades satélites.

Os principais pontos do programa de construção de habitação social eram:

- A construção de 10.000 habitações num período de 10 anos, sendo que em cinco anos foram construídas 12.000 habitações;

- A tipologia predominante de habitações deveria ser de unidades unifamiliares em renque com jardim, banheiro, aquecimento central e cozinha frankfurtiana. Esta consistia em um ambiente concebido sobre o modelo de um vagão restaurante, uma cozinha laboratório que organizada sob a égide de uma funcionalidade extrema e uma

${ }^{24}$ DREYSSE, D. W. (1988), Les Cites de Ernest May - Guide d'architecture des cites nouvelles de Francfort (1926-1930). 
espacialidade mínima deveria permitir o preparo de refeições num tempo mínimo, possibilitando a liberação da mulher para outras atividades. ${ }^{25}$ Somente $28 \%$ das habitações foram produzidas como unidades unifamiliares;

- A pré-fabricação de elementos, a implementação de processos de racionalização do canteiro de obra, mesmo quando fossem utilizados materiais convencionais como o tijolo e a normatização de elementos da construção, incluindo-se os elementos de acabamento;

- A tipificação das habitações, resultante dos processos de racionalização, em renque, sobrepostas, ou multifamiliares, simbolizando um ideal de produção de uma habitação com a mesma qualidade para qualquer habitante da cidade.

Além disso, em função da sua localização na periferia ou distante do centro, ainda que, vias de regra, fossem ligadas a um serviço de transporte coletivo - principalmente trem urbano e metrô - as Siedlungs e particularmente as cidades satélites eram servidas por comércio local, e vários outros equipamentos, de igrejas a escolas e respondendo a ideais sociais mais amplos centros comunitários, parques e lavanderias de uso comum.

As Siedlungs constituíram-se em um modelo de produção de habitação social moderna, no qual os preceitos modernos construtivos, claramente visualizados nas suas tipologias, aliavam-se a ideais sociais, também, modernos. Esta articulação de ideais era representada por novos espaços de uso privado inseridos em espaços públicos, servidos por equipamentos também públicos. A Siedlung "Westhausen" (figura 10 e figura 11) é representativa da articulação citada.

\footnotetext{
${ }^{25}$ A cozinha de Frankfurt foi concebida pelo arquiteto vienense Grete Schutte-Lihotzky.
} 


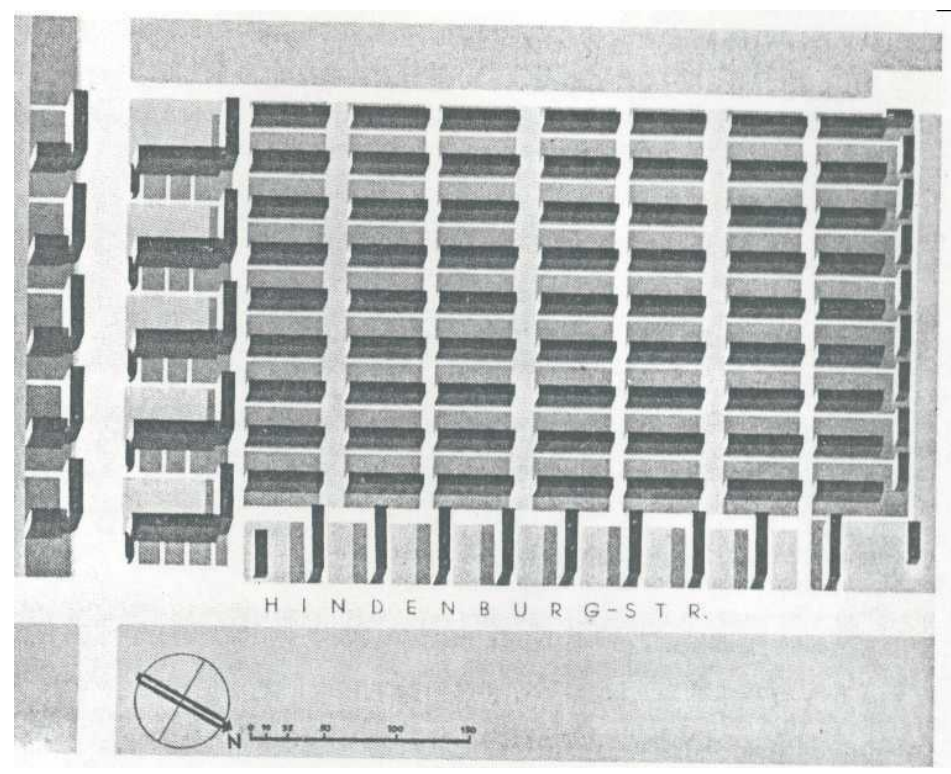

Figura 10 - Westhausen, Plano de 1929 - Ernest May;

O seu rigor construtivo e de "montagem urbana" é exemplar da racionalização construtiva transposta para a organização espacial a indicar uma igualdade social. Essa igualdade já estaria introduzida na questão do espaço mínimo, ou melhor, habitação mínima. Junto a essa idéia se unem estudos sobre os espaços coletivos, que seriam essenciais para o novo modo de vida. Como dizia Gropius ${ }^{26}$, era muito difícil se pensar em algo que serviria para pessoas e culturas tão diferentes, tipos de famílias mais diversas possível, mas esse era um problema a ser levado em conta no resultado de um produto tipo.

“O problema da habitação mínima é questão de um mínimo elementar de espaço, ar, luz, calor, que o homem precisa para não sofrer, por causa da moradia, inibição no pleno desenvolvimento de suas funções vitais, portanto um mínimo de modus vivendi em vez de um modus non moriendi. Este mínimo varia segundo as condições locais da cidade e país, paisagem e clima; a mesma área de espaço livre tem função iversa numa rua estreita do centro da cidade e num subúrbio menos habitado." 27

\footnotetext{
${ }^{26}$ GROPIUS, W. (1972); Bauhaus: Nova Arquitetura. p. 148.

27 idem. p. 151.
} 


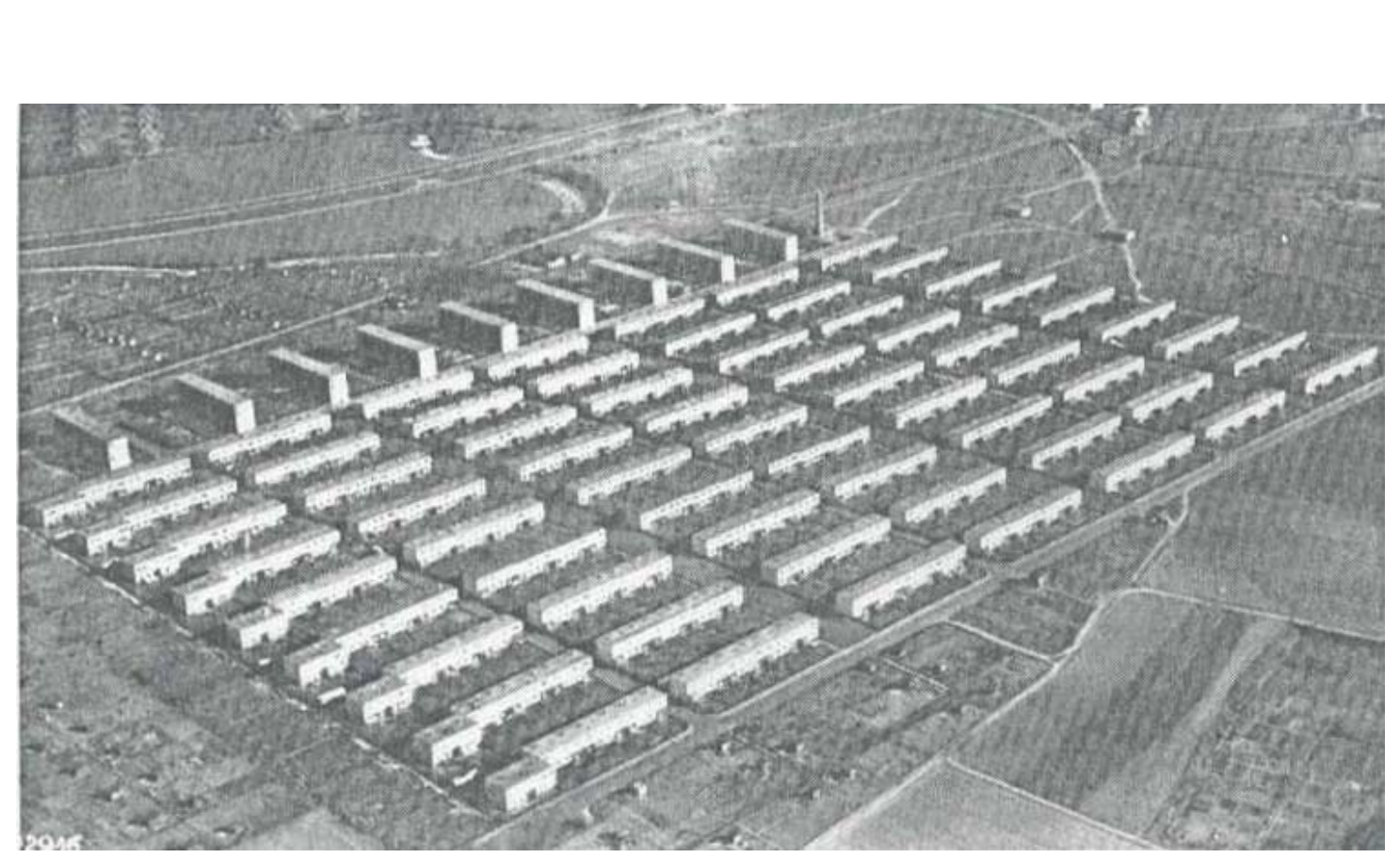

Figura 11 - Westhausen, vista aérea de 1932 - Ernest May;

Nessa época já se trabalhava com a noção de que para suprir a diferença entre o valor do salário do trabalhador e o valor da construção (de sua moradia) era necessário a participação do Estado junto ao mercado da construção. Então, para que fosse possível a construção de habitação mínima de qualidade, teria que exigir do Estado que:

“1) Evite o desperdício de dinheiro público com casas demasiado grandes e facilite, em contraposição, os fundos para a construção de habitações mínimas, para a qual é preciso determinar um limite máximo de tamanho;

2) Baixe os índices contratuais para a habitação mínima;

3) Ponha à disposição os terrenos de construção e os retire da especulação imobiliária;

4) Facilite o mais possível às normas de zoneamento e os códigos de obra." 28

\footnotetext{
${ }^{28}$ GROPIUS, W. (1972); Bauhaus: Nova Arquitetura. p. 155.
} 
Como é possível notar na construção da Westhausen (figura 6), existe uma preocupação com a disposição racional das lâminas na implantação ao terreno, para se obter uma habitação sadia através de estudos de luminosidade feitos por vários arquitetos na época. Esse afastamento entre lâminas é resultado de uma proporção da altura do bloco e distância entre blocos.

Para se entender o todo é essencial se criar uma unidade mínima, ou o mínimo para se sobreviver em uma vizinhança próxima, foi então que Gropius propôs essa classificação para se chegar a maior unidade, ou seja, a cidade.

“- A menor das unidades administrativas independentes - e isto vale tanto para os distritos rurais quanto para os urbanos - seria a unidade de vizinhança, com 5.000 a 8.000 habitantes. Isto corresponde a um número de habitantes suficientemente grande para sustentar uma escola primária produtiva.

- A unidade administrativa subseqüente, na escala de grandeza, abrangeria respectivamente 5 a 10 unidades de vizinhança, com 25.000 a 75.000 habitantes, com 1 ou 2 ginásios centrais.

- A última unidade de vizinhança seria a grande cidade, ou metrópole, com uma seleção dos melhores colégios e universidades." 29

Após a formação da cidade com todas as suas unidades administrativas, viria uma das maiores contribuições para o local, adicionar ao núcleo dessa cidade os centros comunitários, como já visto, na Siedlungs foram implantadas estruturas básicas para a vizinhança ou mesmo a própria colônia formada.

${ }^{29}$ GROPIUS, W. (1972); Bauhaus: Nova Arquitetura. p. 175. 
"O estabelecimento de centros comunitários no núcleo das cidades e dos conjuntos habitacionais é mais importante e necessário ainda que a própria construção de habitações, pois estes centros servem de base cultural em que o indivíduo poderá desdobrar plenamente a sua estatura no seio da comunidade." 30

Como veremos nos capítulos 2 e 3, muitos desses conceitos foram aplicados a construções feitas no Brasil, e principalmente, no capítulo 3 veremos as ligações com o projeto do Conjunto Habitacional Zezinho Magalhães Prado.

30 Idem, p. 183. 


\section{Movimento Moderno e Habitação Social no Brasil}

\section{Formação do contexto produtivo da indústria da construção civil no Brasil.}

As primeiras grandes construções após a República foram os portos ou ampliações dos mesmos, para o recebimento de vapores transoceânicos. 0 Porto de Santos, tido como a primeira grande obra republicana (VARGAS, 1995), teve o primeiro trecho terminado em 1890, executado por uma das primeiras empresas nacionais de construção civil, a Gafrée - Guinle e Cia. Com essa atividade, pode-se dizer que começa no Brasil, então, a organização industrial da construção civil.

O Porto do Rio de J aneiro, por sua vez, foi construído por uma empresa

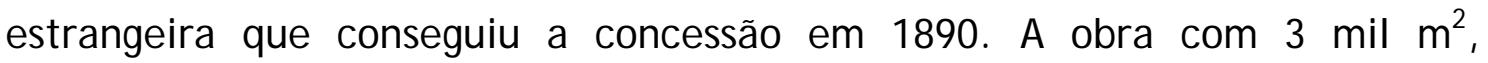
condizentes com o primeiro projeto, foi terminada em 1910. Já o Porto do Recife que teve a concorrência aberta antes da do Rio de Janeiro, teve suas obras concluídas apenas em 1918. Na seqüência foram executados ou ampliados, o Porto de Salvador em 1914, no sul o de Rio Grande teve seu término em 1919, e o de Vitória em 1940.

Apesar da obra pioneira da Gafrée - Guinle, apenas em 1919 foi organizada a primeira empresa nacional especializada em construções portuárias, a Civilhidro (Companhia Nacional de Construções Civis e Hidráulicas). Até então, com exceção do Porto de Santos, todos os outros foram financiados por meio de taxas cobradas por exportação e importação ou por meio de empréstimos estrangeiros.

Após o inicio da construção dos vários portos, outra atividade da engenharia civil se desenvolveu após a Proclamação da República, a hidrologia. Assim, têm início o tratamento de esgoto, a retificação e canalização de córregos e rios, a drenagem de áreas alagadiças e 0 
escoamento das águas pluviais em nossas cidades. Se as primeiras obras de engenharia, o Portos, indicavam o aperfeiçoamento de estruturas para a exportação de produtos primários, o segundo conjunto de obras já se "internalizando" na estrutura urbana o conhecimento técnico, através da remodelação e do reaparelhamento das cidades. Associado a esse segundo conjunto surge a produção de energia elétrica, que indica uma reorganização, ou pelo menos, o desenvolvimento de um novo perfil produtivo, o industrial na cidade:

"O rápido desenvolvimento industrial que se deu no fim do século passado (século XIX) no Rio de Janeiro e, a partir da primeira década do século (século XX), em São Paulo, obrigou o suprimento de energia elétrica à indústria" ${ }^{1}$

A primeira hidrelétrica de grande porte no Brasil foi a Usina de Parnaíba sobre o Rio Tietê, inaugurada em 1901, que foi construída pela empresa canadense The São Paulo Railway, Light and Power Co. Ltda., que vem a se tornar a grande investidora nessa área no país.

A industrialização requer que a cidade seja repensada. Ainda que timidamente, a cidade industrial passa a compor a realidade do país. Exige novas respostas, que técnicos nacionais são chamados a elaborar, o caso de Saturnino de Brito é emblemático, ao mesmo tempo em que serviços urbanos, via de regra, administrados por companhias estrangeiras são introduzidos nas cidades. No mesmo período algumas estradas de rodagem são abertas exigindo novas concepções, em função dos veículos motorizados, e mais tarde seriam implantados os aeroportos.

Com a aceleração no crescimento do país, que articula indústria própria, com importação de produtos manufaturados e redes de infraestrutura urbana e territorial, estabelece-se um contexto para a formação, ou aprofundamento da formação técnica no país. Desta forma, começa a se dar

\footnotetext{
${ }^{1}$ VARGAS, M. (org. ) (1995). História da Técnica e da Tecnologia no Brasil. UNESP/ CEETPS. São Paulo, pág. 198.
} 
valor, cada vez mais, a pesquisa tecnológica, que de todo modo, só foi introduzida no Brasil nos anos 1920, e foi adotada como definição:

\begin{abstract}
"Estudo ou tratado das aplicações de métodos, teorias, experiências e conclusões das ciências ao conhecimento dos materiais e processos utilizados pela técnica". ${ }^{2}$
\end{abstract}

Essa pesquisa tecnológica tem uma função importantíssima para o desenvolvimento de materiais e técnicas nacionais, e as primeiras instituições que se propuseram, no início do século, foram: o Serviço Geológico e Mineralógico do Brasil, no Rio de Janeiro; o Instituto Nacional de Tecnologia (INT), também no Rio de Janeiro em 1921, o Gabinete de Resistência de Materiais da Escola Politécnica de São Paulo; e o Instituto Agronômico, de Campinas.

“(...) o processo de industrialização, iniciado durante a Primeira Guerra, necessitou da pesquisa tecnológica para resolver os problemas técnicos correlacionados. Não se pode dizer que, com o início da industrialização, aparece, necessariamente, a pesquisa tecnológica; mas isso aconteceu e, como resultado, o desenvolvimento econômicoindustrial do país foi garantido". ${ }^{3}$

Um dos pontos importantes para o desenvolvimento da pesquisa no Brasil, foi à organização em 1893, do Gabinete de Resistência dos Materiais vinculado à Escola Politécnica de São Paulo. Em 1926, o Engo. Ary Frederico Torres trouxe a proposta de transformar o gabinete no Laboratório de Ensaio de Materiais (LEM), que teve as pesquisas subdivididas em: aglomerantes e concreto, metais e madeira, em abril de 1934, o LEM adquiriu uma nova

\footnotetext{
${ }^{2}$ Idem. pág. 213.

${ }^{3}$ VARGAS, M. (org.) (1995). História da Técnica e da Tecnologia no Brasil. UNESP/ CEETPS. São Paulo, pág. 216.
} 
conformação, ampliando o seu escopo de atividades, sendo transformado no Instituto de Pesquisa Tecnológica (IPT) - autarquia vinculada à Escola Politécnica. A partir de então se pode afirmar que ficou definitivamente instituída a pesquisa tecnológica na Universidade de São Paulo.

Tanto o aço como o cimento, necessitavam de fábricas nacionais para a expansão do seu uso. Já no século XIX em 1897, surgiu a primeira fábrica de cimento chamada Rodovalho, atual Votorantim e, (apenas) em 1921, o aço foi produzido no Brasil em bases industriais pela Companhia Siderúrgica BelgoMineira.

\section{As Mudanças a partir de 1930}

Os conhecidos desdobramentos políticos, advindos da crise do café, como parte das transformações que incidiram sobre as economias de todos os países com a crise de superprodução, que levou ao crack da Bolsa de Nova lorque em 1929, aprofundaram a industrialização e a ampliação das estruturas urbanas já em curso, mas sobretudo, em novas condições:

\footnotetext{
“(...) a partir da crise do café na década de 1930, inicia-se uma transformação estrutural, sugestivamente denominada industrialização substitutiva de importações. Nessa fase, ao contrário da anterior, o desenvolvimento industrial foi impulsionado pelas dificuldades do setor exportador, estando o crescimento de renda mais ligado ao desenvolvimento no mercado interno". ${ }^{4}$
}

\footnotetext{
${ }^{4}$ Motoyama, Shozo (1994); (org) Tecnologia e Industrialização no Brasil - Uma perspectiva Histórica. ed. UNESP - São Paulo. pg.17/ 18.

Emília Viotti da Costa em Da Monarquia à República, momentos decisivos, São Paulo: UNESP, 1999, expõe assim as ligações entre o contexto político e o contexto social: "O crescimento da população, o desenvolvimento industrial, a urbanização, a formação do proletariado e a ampliação da classe média, a crise que atingiu a economia cafeeira, a crise internacional de 1929, as contradições entre os vários setores de produção e o aparecimento de novas ideologias propiciaram a revolução de 1930, que inaugurou um novo período da história do Brasil". Para a autora, em função dos avanços e retrocessos políticos e econômicos, as mudanças e os conflitos existentes ocorrem sob a "camuflagem da modernização" do país.
} 
O trecho citado acima é a base para a teoria de industrialização no país, que se dá articulada ao café no seu apogeu, mas que reforça com a sua crise. Neste jogo econômico a indústria da construção é forjada e em um segundo momento irá conhecer a participação do Estado, através do desenvolvimento da pesquisa tecnológica e da consolidação do ensino de engenharia, que dará novo impulso à iniciativa privada, gerando capacitação e mercado para formação de empresas fornecedoras de máquinas, equipamentos e materiais de construção (MOTOYAMA, 1994).

“A industrialização em São Paulo se fez por meio da poupança gerada pelo café, sendo entretanto aplicada diretamente nas estradas de ferro (Paulista, Ituana, Mogiana e Sorocabana, notadamente), nos portos (de Santos e do Rio de J aneiro) necessários para o escoamento da própria produção cafeeira, e nas companhias organizadas para edificar os prédios públicos (Ramos de Azevedo, no final do século passado e Roberto Simonsen, nas primeiras décadas deste). Estas áreas absorveram os primeiros engenheiros brasileiros. Foi, entretanto, 0 setor da construção dos edifícios públicos (e em seguida privados) que direcionou a pesquisa tecnológica no Brasil, sendo os maiores e mais conhecidos êxitos localizados na utilização do concreto armado. Entre 1920 e 1960, formou-se um conjunto de pesquisadores e projetistas, tanto em São Paulo como no Rio de J aneiro (Ary Torres, Telêmaco van Langendonck, em São Paulo; Emílio Baumgart, Fernando Lobo Barbosa Carneiro, Joaquim Cardoso, no Rio de Janeiro), que vieram a caracterizar uma escola brasileira de concreto armado, tendo contribuído para o avanço da tecnologia em nível internacional. " 5

Após a Revolução Constitucionalista de 1932, continuam crescendo os investimentos em pesquisa, como dito anteriormente, através dos institutos

\footnotetext{
${ }^{5}$ Motoyama, Shozo (1994); (org) Tecnologia e Industrialização no Brasil - Uma perspectiva Histórica. ed. UNESP - São Paulo. pg. 201.
} 
de pesquisa. Roberto Simonsen é um dos organizadores do Instituto de Organização Racional do Trabalho (Idort), em 1933; cria também a Escola de Sociologia e Política, em 1934. Havia participado também na formação do Centro das Indústrias do Estado de São Paulo, a futura Federação das Indústrias do Estado de São Paulo (Fiesp). Além destas organizações, foi criado em 1942 o Serviço Nacional de Aprendizagem Industrial (Senai), que contou com a participação de Euvaldo Lobo, presidente da Confederação Nacional da Indústria, e de Simonsen, como representante da Fiesp. ${ }^{6}$

A partir de 1937 os laboratórios nacionais de ensaios já se reúnem para o controle do cálculo do concreto armado, resultando em 1940 a fundação da Associação Brasileira de Normas Técnicas. A pesquisa e aplicação do concreto desenvolveram-se intensamente no Brasil, com grande repercussão, a ponto da revisão da norma de 1960 ter sido a base para a elaboração em 1963 da Primeira Norma Internacional do Comitê Europeu do Concreto.

A partir de 1940, começa a construção da usina siderúrgica de Volta Redonda, sendo finalizada apenas com o final da Segunda Guerra Mundial. Com o início de ações mais efetivas de Planejamento Econômico a industrialização conhecerá uma nova fase no país, além do que, é nessa época que começa a nacionalização de serviços públicos (MOTOYAMA, 1994).

\section{Industrialização de Habitação Econômica}

A industrialização, desde o seu início, além de exigir uma nova estrutura urbana, introduz novos programas e redimensiona algumas carências:

\footnotetext{
${ }^{6}$ Idem. Pg. 16. Criado em 22 de janeiro de 1942, pelo decreto-lei 4.048 do presidente Getúlio Vargas, o SENAI surgiu para atender a formação de mão-de-obra para a indústria de base. Na ocasião, suas premissas eram de que sem educação profissional não haveria desenvolvimento industrial para o país.
} 
"O debate sobre a construção econômica da habitação surge, no Brasil, de duas fontes: a primeira foi o reconhecimento - pelo menos do discurso - da necessidade de alojar de forma higiênica e econômica as massas urbanas que marcam sua presença nas cidades brasileiras exatamente a partir do último quartel do século XIX, período da Segunda Revolução Industrial, momento em que se aceleram os processos de urbanização no país". ${ }^{7}$

No Brasil, a partir de 1920, foram realizados alguns debates sobre habitação no Instituto de Engenharia, mas é com a aproximação aos ideais do Movimento Moderno, de forma heterogênea, por parte de profissionais, mas constante, ainda que se verifique resistência à linguagem moderna, que os interesses se voltam com mais intensidade para a produção habitacional.

Na década de 1930, o poder público passa a estimular o poder privado para tentar suprir o déficit que aumentava com o processo acelerado de urbanização que se iniciava.

Em 1931, ocorre em São Paulo, o primeiro Congresso de Habitação, promovido pela Divisão de Arquitetura do Instituto de Engenharia de São Paulo e patrocinado pela Prefeitura Municipal. Contou não só com a presença de engenheiros e arquitetos, mas também médicos, higienistas, sociólogos e políticos. O Congresso procurou identificar soluções para problemas urbanos e habitacionais da cidade, e principalmente, viabilizar a construção de moradias para a população de baixa renda.

Para GITAHY e PEREIRA (2002) é nesta época que são constituídas as bases de um arranjo mais complexo do setor da construção, o Complexo Industrial da Construção, que se relaciona com os ideais modernos e que compreende o desenvolvimento da indústria de materiais de construção, pesquisa tecnológica, de forma integrada à economia, como um setor estruturado, distinto do fazer construtivo anterior.

\footnotetext{
${ }^{7}$ GITAHY, M. L. C.; PEREIRA, P. C. X. (org.) (2002) 0 complexo industrial da habitação econômica moderna, 19301964. Editora RiMa. São Carlos, São Paulo, pág. 09.
} 
“Entendemos que a década de 1930 foi o momento de consolidação dessas propostas modernas do Brasil, que conseguem reconhecimento social e continuidade política nos anos seguintes, a medida em que se associam e significam um aprofundamento do caráter empresarial da construção habitacional em São Paulo". ${ }^{8}$

É nesta época também que as industriais ligadas à construção se multiplicam e diversificam-se em várias áreas, tais como, produção de materiais e equipamentos, construtoras, escritórios e arquitetura e engenharia e serviços imobiliários, decorrendo disso a denominação "complexo da construção" (GITAHY, PEREIRA, 2002).

“Na promoção dessa modernização da construção, a ação do Estado foi decisiva, tanto na montagem de uma infra-estrutura urbana quanto no apoio à industrialização voltada para o mercado interno. Além de incentivar o capital nacional, o Estado contou com a participação do capital estrangeiro neste reforço". ${ }^{9}$

O esforço para a normalização técnica na indústria da construção tem um papel importante para a industrialização, recaindo também na qualificação do trabalho e do produto, para que se integrasse à proposta moderna de habitação social. Na passagem dos anos 1930, tornava-se hegemônica a noção de habitação econômica moderna e racional, que vinculava a emergência da arquitetura moderna à industrialização da construção.

Um mercado de massas era 0 alvo. A produção em série, a estandardização e a difusão de novas tecnologias, ainda que sempre associadas à produção convencional, ao uso de materiais convencionais, por

${ }^{8}$ GITAHY, M. L. C.; PEREIRA, P. C. X. (org.) (2002) 0 complexo industrial da habitação econômica moderna, 19301964. Editora RiMa. São Carlos, São Paulo, pág. 16.

${ }^{9}$ idem. pág. 17. 
vezes, apenas figurando uma industrialização, que permaneceu por demais incompleta, e na prática repetindo processos antigos, viria atingir diretamente um mercado de massas.

"Os conj untos habitacionais projetados, tanto pela promoção privada quanto pelos Institutos de Aposentadorias e Pensões, criaram uma interpretação brasileira do ideário da Arquitetura Moderna. Desejavase uma cidade iluminada, geométrica, desafogada e funcional" ${ }^{10}$

Há uma indústria que se forma, mas essa indústria compete em desigualdade com processos arcaicos, ou artesanais de construção. Na maioria das vezes ocorre uma associação entre o processo industrial e o processo arcaico.

É dessa época também que se delimitou o campo do arquiteto e do engenheiro, mais precisamente em $1933^{11}$. 0 arquiteto ficou com a concepção do projeto e o engenheiro com a responsabilidade técnica. Com relação ao projeto, o novo nicho encontrado seria a habitação econômica, ou seja, higiênica, moderna e de baixo custo. Na década de 1940 o poder público irá promover a habitação econômica por intermédio da Fundação da Casa Popular e dos Institutos de Aposentadorias e Pensões.

\section{A Questão Habitacional no Brasil}

Historicamente o problema de habitação no Brasil configurou-se de forma diferenciada do contexto europeu. Em um primeiro momento, no final do século XIX, relacionava-se, principalmente, à emergência do trabalhador

\footnotetext{
${ }^{10}$ GITAHY, M. L. C.; PEREIRA, P. C. X. (org.) (2002) O complexo industrial da habitação econômica moderna, 19301964. Editora RiMa. São Carlos, São Paulo, pág. 21.

11 "Em 11/12/1993, no novo Ministério do Trabalho, Indústria e Comércio, a regulamentação das profissões de engenheiro e arquiteto foi obj eto do Decreto Federal no 23.569". Idem. Pág. 29.
} 
livre com a libertação dos escravos e à chegada do volumoso contingente de estrangeiros. Nas primeiras décadas do século XX, o problema foi redimensionado com o processo de industrialização, mesmo que sob a forma de uma industrialização periférica.

Este processo, associado à renovação de idéias sociais, políticas e culturais, gerou uma rápida e crescente urbanização, ainda pressionada por novos contingentes de imigrantes, gerando assim a valorização imobiliária como conseqüência da distorção entre oferta e procura. Neste período, fim do século XIX e início do século XX, a atividade de construção habitacional já vinha se organizando de forma capitalista, pelo menos em alguns setores, de qualquer maneira prenunciando a articulação entre processos industriais e anteriores, conforme citado anteriormente.

A moradia de aluguel foi à forma predominante de habitação da massa trabalhadora urbana no começo do século. Estas eram oferecidas no mercado e constituíam um atraente investimento privado, uma oportunidade sem riscos pelos juros altos, relação entre oferta e demanda e pela ausência de qualquer lei que intermediasse a relação proprietário e demanda.

Desta forma os trabalhadores menos favorecidos acabavam sem opções, a não ser os em cortiços. Nas cidades de São Paulo e Rio de Janeiro esses tiveram o crescimento cada vez mais acentuado próximos ao centro da cidade. Este quadro fez-se sentir já no final do século XIX, gerando preocupações sociais por parte da elite econômica, que associava autoritarismo social com cientificismo sanitário. Raquel Rolnik expõe a posição do Conselho Superior de Saúde Pública de São Paulo, em publicação de 1986:

"Em uma cidade como esta (...) com tantos cortiços que em si recebem uma lotação superior à que prescrevem os preceitos da ciência, é fácil prever que eles representam um vulcão pronto a 
fazer erupção, logo que se apresentam condições favoráveis. E não se pode duvidar que essas asquerosas residências devem ser extintas, por isso que os fatos demonstram que elas representam uma sala de espera da morte." 12

Segundo BONDUKI (1998), havia cinco tipos de habitação que abrigavam os trabalhadores: o hotel-cortiço, a casa de cômodos, os cortiços improvisados, o cortiço-pátio e "a casinha". Apesar das diferentes configurações físicas destes espaços, eram genericamente classificados, pelos higienistas, como cortiços, demonstrando o preconceito em relação à população atendida.

Na interpretação social preconceituosa do higienismo, a população pobre é objeto (vítima) das doenças, mas também, sujeito e veículo de toda sorte de malefícios:

"O cortiço, na opinião do saber médico, significava o espaço da proliferação e da contaminação dos focos infecciosos". ${ }^{13}$

Há uma forte presença desta visão na questão urbana brasileira entre 0 final do século XIX e início do século XX, sobretudo em São Paulo e Rio de J aneiro. No Rio de Janeiro, objeto de diversas intervenções sanitaristas, que procuravam requalificar a cidade como capital, e da idéia de "centro limpo", o cortiço passou a ser proibido, de acordo com o artigo 2 do regulamento geral de construções e consertos de prédios de 1903:

“(...) nos cortiços existentes não se permitirá obra alguma, concerto ou reparação que possam garantir sua segurança, só se tolerando

\footnotetext{
${ }^{12}$ ROLNIK, Raquel (s.d.). Cada um no seu lugar (São Paulo, início da industrialização: geografia do poder). pg. 55.

${ }^{13}$ CARPINTÉRO, M. V. T (1997). Os Engenheiros -arquitetos e a formulação da política Habitacional no Brasil (São Paulo 1917-1940). pg. 57.
} 
pintura de caiação e não se permitindo novas edificações semelhantes em ponto algum." 14

Assim, cerca de 600 habitações coletivas, que abrigavam mais de 13.000 pessoas foram fechadas, sem que o prefeito Pereira Passos, apresentasse qualquer solução alternativa de moradia.

“Com a proibição da instalação de cortiços, casas de operários e cubículos, proibiu-se genericamente a presença de pobres no centro da cidade, que no momento em estudo era o principal objeto de investimentos através dos chamados "Planos de Melhoramentos da Capital." 15

Como em tantos outros domínios sociais a irracionalidade da produção capitalista da moradia, do loteamento indiscriminado, da precariedade dos serviços de água e esgoto, depositou no Estado a responsabilidade em exercer algum tipo de controle sobre a produção do espaço urbano, ainda que predominassem as concepções liberais. Sendo assim, para Bonduki (1998):

"o poder público atacou em três frentes: a do controle sanitário das habitações; a da legislação e código de posturas; e a da participação direta em obras de saneamento das baixadas, urbanização de área central e implantação da rede de água e esgoto." 16

Mesmo assim o papel do Estado na produção de habitação limitou-se a incentivar sociedades particulares a investir nos programas de habitação das Vilas Operárias. As medidas tomadas neste período, tanto no Rio de Janeiro, quanto em São Paulo, não tratavam diretamente do problema habitacional nas reformas urbanas. Estas eram feitas apenas com a intenção de "limpar" o

\footnotetext{
${ }^{14}$ BACKHEUSER, apud CARPINTÉRO, M. V. T (1997). Os Engenheiros -arquitetos e a formulação da política Habitacional no Brasil (São Paulo 1917-1940). pg.67.

${ }^{15}$ ROLNIK, Raquel (2003). A cidade e a lei: legislação, política urbana e territórios na cidade de São Paulo. Pg. 37.

${ }^{16}$ Para a influência sanitarista no pensamento e na legislação urbana no Brasil ver FELDMAN, Sarah (2001). Avanços e limites na historiografia da legislação urbanística no Brasil. IN R. B. Estudos Urbanos e Regionais. № 4. Pp 33-47
} 
centro das cidades, removendo os cortiços, mas sem a preocupação de solucionar o foco do problema ou promover alternativas a estas condições de moradia. A perspectiva de mudança solicitava outras formas de ação do Estado:

"Ao contrário dos cortiços as vilas operárias deveriam compor um conjunto de casas higiênicas conforme os padrões exigidos pela Comissão de Higiene Pública, de forma a cumprir sua característica principal de afastar toda promiscuidade existente nos cortiços." ${ }^{17}$

As Vilas Operárias de iniciativa privada significam, no entanto, mais uma fonte de lucro para os empresários, que uma solução para os operários. Segundo CARPINTÉRO (1997), os critérios de distribuição das casas implicavam questões de caráter íntimo, conjugal, cor, vícios, número de filhos, saúde e desempenho no trabalho.

Para verificar a mudança de rumos da questão habitacional propomos abordar três fatos que merecem destaque na década de 1930, mesmo não tento significados exatamente equivalentes: A política do governo de Getúlio Vargas, o Primeiro Congresso de Habitação e a configuração do "complexo industrial da construção".

No quadro de renovação política e social que o forjou, no governo Getúlio Vargas, embora as questões sanitárias ainda estivessem presentes, a questão da moradia passa a representar papel primordial das condições de sobrevivência na reprodução da força de trabalho, que influía no modo de vida e na formação moral e ideológica dos trabalhadores. A moradia passa a ser uma questão de ordem pública, de estabilidade política e econômica (MANOEL, 2003). A partir da década de 1930, foi tomando-se consciência de que a iniciativa privada não tinha possibilidade de prover habitações para os

${ }^{17}$ CARPINTÉRO, M. V. T (1997). Os Engenheiros -arquitetos e a formulação da política Habitacional no Brasil (São Paulo 1917-1940). pg. 67. 
setores de baixa renda sem o apoio do poder público, como se queria durante a Primeira República (BONDUKI, 1998).

Foram várias as ações governamentais e propostas de intervenções no campo da habitação social: de um período em que a meta fundamental era a de construir casas para atrair e abrigar mão de obra estrangeira passou-se para a proposta de propiciar moradia para o operário urbano.

O objetivo principal do Congresso de 1931, citado anteriormente, foi buscar soluções para os problemas urbanos de São Paulo e, dentre eles, viabilizar a construção de moradias para a população de baixa renda. (CARPINTÉRO, 1997).

As discussões entre os técnicos abordaram conceitos relacionados à racionalização da construção e reafirmaram a importância da construção em série para as moradias econômicas, como comenta GITAHY e PEREIRA, quando abordam as questões que envolveram o Congresso.

“É dentro dessa perspectiva, racional e de industrialização da construção, que o Primeiro Congresso de Habitação defendia a necessidade de conhecer melhor os recursos dos materiais de construção, controlar sua utilização e calcular os gastos dos materiais. Assim, na passagem para os anos 1930, tornava-se hegemônica a noção de habitação econômica moderna e racional, que vinculava a emergência da arquitetura moderna à industrialização da construção." (GITAHY, PEREIRA, 2002: 18)

Há algumas concepções em formação, há alguma arquitetura moderna, como demonstra a produção de Warchavchik, há uma arquitetura "geometrizante", que busca uma padronização de projeto, como a produção do Depto. de Obras Públicas em São Paulo, ${ }^{18}$ para alguns buscando uma

\footnotetext{
18 SEGAWA, Hugo, Arquiteturas no Brasil 1900-1990, Vertentes Racionalistas: As Obras Públicas, pp. 66-72.
} 
racionalidade, mas a vinculação entre arquitetura e construção, projeto e obra, ainda é um perspectiva que alguns arquitetos e intelectuais vislumbram e veiculam de forma exploratória.

O Primeiro Congresso de Habitação foi antecedido por vários encontros, palestras e reuniões também promovidos pelo Instituto de Engenharia a partir dos anos 1920, que trouxeram adeptos do urbanismo moderno em todo Brasil (CARPINTÉRO, 1997). A habitação passa a ter importância para os arquitetos na emergência da Arquitetura Moderna, assim os arquitetos envolvidos com a produção habitacional adotaram parcialmente os ideais concebidos pelo Movimento Moderno, buscando abordar aspectos formais, produtivos, sociais e culturais.

Tendo em vista as experiências realizadas em outros países como Inglaterra, França e Estados Unidos, a partir de um conjunto de conhecimentos técnicos, sempre acompanhados de preceitos morais e higiênicos. (...) estes médicos, engenheiros, arquitetos discutiam a necessidade de uma interferência nos costumes e hábitos desta população a partir da organização do espaço da casa." 19

Com o governo Vargas, particularmente após 1937, a dita "interferência" ganharia o status de projeto. Ou seja, um projeto de formação do novo homem brasileiro e urbano, ainda que sob a égide do populismo. ${ }^{20}$

\footnotetext{
19 CARPINTÉRO, M. V. T (1997). Os Engenheiros -arquitetos e a formulação da política Habitacional no Brasil (São Paulo 1917-1940). pg. 108.

${ }^{20}$ Sobre esta questão no texto "Lar e Família: o discurso assistencialista sobre habitação popular nos anos 40 e 50", Flávia Brito do Nascimento comenta"O Estado toma para si o papel de ingerência na sociedade civil, organizando-a de acordo com seus preceitos de cidadania e inserção política, trazendo à tona a nossa 'verdadeira' alma nacional. Era o 'homem novo' que daria início a uma nova era' (p. 44) e depois localiza o papel da moradia nesse processo ' ... construir casa e vias operárias (...) educar o gosto pela casa ...' (p.55), in Revista Risco no. 3, www.risco.eesc. usp. br acessado em 05/ 06/ 07.
} 
O valor da arquitetura moderna brasileira é reconhecido nacional e internacionalmente. Entretanto, apenas recentemente a historiografia da arquitetura moderna relata a produção da habitação operária no período em que esta arquitetura se fez prodigiosa, sendo as obras de Affonso Eduardo Reidy - conjuntos Pedregulho (figura 12) e Gávea, talvez os exemplos ainda hoje mais conhecidos.

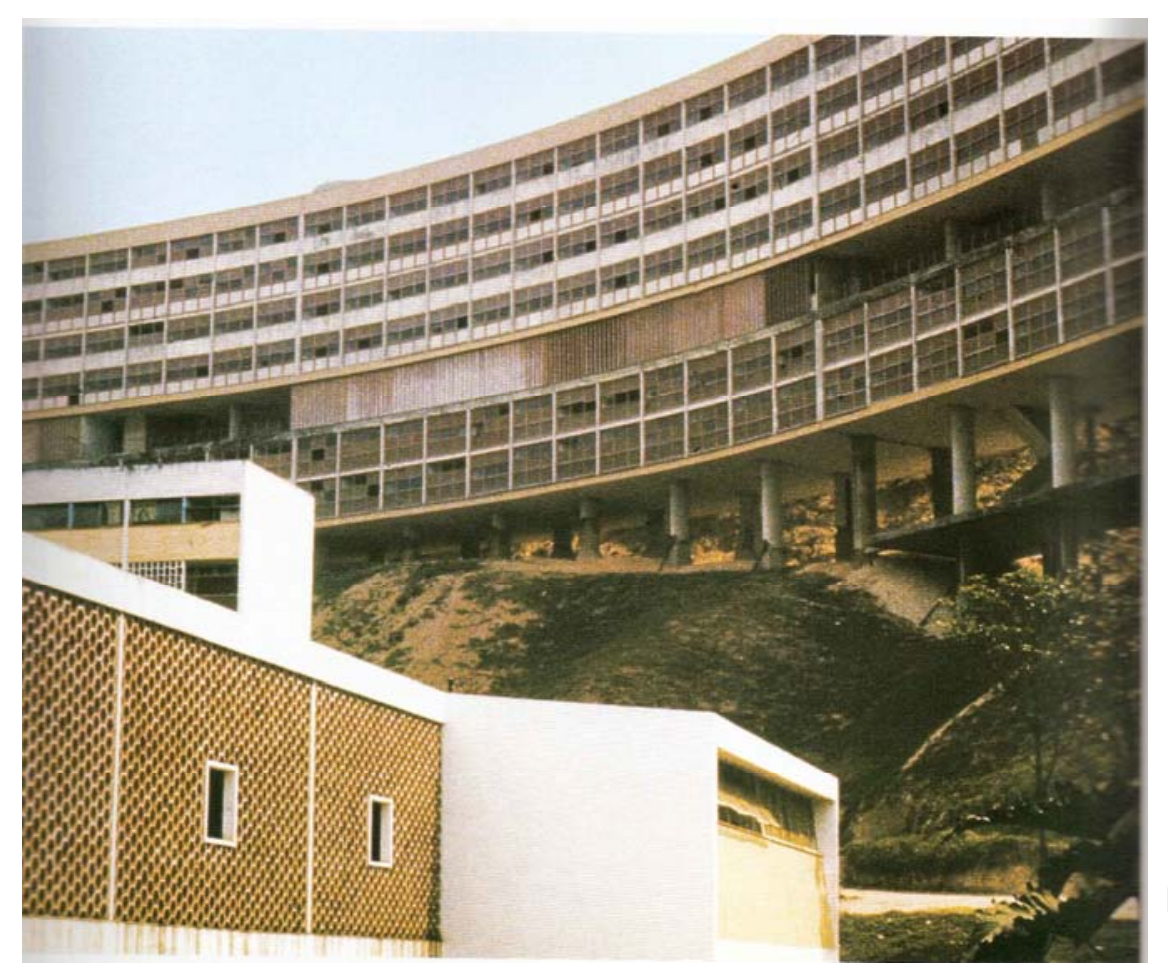

Figura 12 -

Pedregulho

Fonte: Taschen.

A concretização dos ideais modernos pode ser verificada, sob vários aspectos, em um conjunto significativo de projetos e obras habitacionais, encomendados a profissionais que se destacaram na constituição da Arquitetura Moderna como: Attílio Corrêa Lima, MMM Roberto, Eduardo Kneese de Melo, Paulo Antunes Ribeiro, Carlos Frederico Ferreira, entre outros. São soluções pioneiras no Brasil que tratam a questão da habitação como projeto de cunho social, pela vontade política de solucionar o problema e pelo conhecimento técnico adquirido. 
Alguns destes arquitetos participaram da produção de alguns dos conjuntos habitacionais realizados pelos Institutos de Aposentadorias e Pensões - IAPs e pela Fundação da Casa Popular - FCP, no período entre anos 1930 e 1964, que englobam as 142 mil unidades. Esta produção foi bastante reduzida diante da produção em massa feita mais tarde pelo Banco Nacional de Habitação - BNH (entre 1964 e 1985), mas muito expressiva do ponto de vista qualitativo e marca a origem da produção da habitação social no país (BONDUKI, 2001).

Os IAPs e, particularmente o IAPI, foram os órgãos que mais se empenharam nesta produção e na busca de sua qualificação, como é possível observar nas diretrizes gerais de projeto para os conjuntos residenciais destes Institutos, as quais propunham: enquadramento às características econômicas do meio ambiente; criação de rede serviços e reforços das redes de abastecimento de água potável e estações de tratamento de esgoto; preferência pela moradia em edifícios coletivos como um processo de barateamento das residências acessíveis às grandes massas de associados; definição de projetos padronizados; uso de instalações simples, padronizadas e duráveis e estruturas permanentes (IAPI, 1950).

Outra instituição que atuou no período, importante de ser destacada foi o Departamento de Habitação Popular da Prefeitura do Distrito Federal:

“(...) do ponto de vista da arquitetura, o mais importante, por contar com profissionais como a Enga . Carmen Portinho, que foi sua diretora, e dos arq. Affonso Eduardo Reidy e Francisco Bolonha, que proj etaram os conj untos habitacionais." 21

O Projeto Integrado de Pesquisa Habitação Econômica e Arquitetura Moderna no Brasil (1930-1964) - desenvolvido entre 1995 e 2001 - revelou

${ }^{21}$ BONDUKI, N. G; KOURY, A.P.; MANOEL, S. (2003). Análise tipológica da produção de habitação econômica no Brasil (1930-1964). 
grande variação tipológica nos primeiros conjuntos habitacionais produzidos, conjugando vários modelos de blocos, casas e edifícios.

\begin{abstract}
"Este conjunto de experiências, sem dúvida, foi um momento importante de consolidação da experiência moderna para a arquitetura brasileira onde os arquitetos se depararam com 0 desafio das propostas dos primeiros Congressos Internacionais de Arquitetura Moderna - CIAM, La Sarraz (1928), Frankfurt (1929) e Bruxelas (1930), que constituíram o espaço mínimo da moradia e a racionalidade construtiva como o centro das preocupações da arquitetura moderna a partir do final dos anos vinte. A riqueza tipológica e urbanística conseguida por estes conjuntos e levantada no escopo desta pesquisa, nos permite realizar tal afirmação." 22
\end{abstract}

$\mathrm{Na}$ observação geral de alguns exemplos da produção habitacional promovida pelo Estado no período, percebe-se uma grande amplitude de referência de idéias sobre a atuação frente à cidade industrial. Pela filiação corbusiana de nossa arquitetura moderna, ou pelo menos a filiação que a historiografia de arquitetura mais divulgou, era de se esperar uma configuração dos conjuntos habitacionais baseados nas experiências do tipo CIAM, entretanto, fica claro um repertório maior, com analogias a propostas e projetos residenciais, como apontadas por ARís (1991), que remetem a cidade jardim e a cidade concentrada, e as respectivas relações entre espaço público, privado e coletivo.

Como exemplos de projetos e obras que se destacam por equacionar essas relações e ainda enfrentar os grandes desafios tecnológicos da época, destacam-se:

22 idem. 
- Conjunto Residencial Várzea do Carmo (Glicério, São Paulo): Projeto desenvolvido por uma equipe de arquitetos coordenada por Attílio Corrêa Lima em 1938, para o IAPI. Propunha diferentes tipologias de 4, 10 e 11 pavimentos para alcançar o número previsto de 4038 unidades. Além da grande escala, o projeto também visava a racionalização e a estandardização das unidades com obj etivo de reduzir custos.

- Conjunto Residencial Operário em Realengo (Rio de Janeiro, 1942): Projetado por Carlos Frederico Ferreira, chefe do Serviço de Arquitetura do IAPI. Com várias tipologias, foi o primeiro conjunto de grande porte no país (mais de 2.000 unidades habitacionais). Nele Frederico Ferreira pode concretizar suas idéias sobre habitação, arquitetura e urbanismo na concepção de várias tipologias. "Mais do que um projeto de moradia, o conjunto representou a concretização de um projeto de vida, onde 0 arquiteto procurou a modernização do homem através da modernização do espaço." (BONDUKI, 2001). Destacam-se neste conjunto, além da escala inédita e teste de tipologias, a pré-fabricação de componentes e a utilização de máquina de blocos de concreto no canteiro.

- Conjunto Habitacional de Pedregulho (Rio de Janeiro, 1946): Projetado pelo arquiteto Affonso Eduardo Reidy e promovido pelo Departamento de Habitação Popular da Prefeitura do Distrito Federal para abrigar funcionários municipais. Do ponto de vista da arquitetura Moderna este foi o Conjunto Habitacional que mais se destacou, com repercussão também no exterior. 0 projeto, que compreende quatro blocos de habitação, com 260 metros de extensão, contendo 272 apartamentos de diferentes tipologias, destaca-se pela forma sinuosa, pelo grande porte de sua estrutura em concreto e pelos equipamentos agregados. (figura 12)

Entre muitos outros, dos quais ainda pode-se citar: Conjunto Residencial Passo d'Areia do arq. Marcus Kruter, em Porto Alegre (IAPI, 
décadas de 1940/50); Conjunto Residencial J apurá, arq. Eduardo Kneese de Melo, em São Paulo (IAPI, décadas de 1940/50); Conjunto Residencial de Deodoro, arq. Flávio Marinho Rego, Rio de J aneiro (FCP, década de 1950); etc.

A produção de Habitação "Social" da FCP, dos IAPs e do Departamento de Habitação Popular da Prefeitura do Distrito Federal não pode ser compreendida fora do quadro da introdução da arquitetura moderna no país. Ou seja, enfrentando toda sorte de dificuldades materiais (retardo da produção industriai) e políticas (autoritarismo que também retardou políticas sociais), uma parcela razoável dos arquitetos modernos absorveram 0 modernismo objetivando "participar ao nível da construção" das mudanças sociais como afirmou Kopp sobre o modernismo em geral.

Entretanto, o reconhecimento tardio que obteve demonstra uma incompreensão das qualidades e potencialidades do próprio modernismo brasileiro, ou da leitura que a historiografia tradicional fez da arquitetura moderna brasileira, privilegiando mais as grandes obras institucionais, sedes e instituições governamentais e mesmo a arquitetura unifamiliar.

As experiências relatadas e os objetivos propostos possuem como pano de fundo, a articulação entre o sistema produtivo e às novas concepções de moradia e de cidade elaboradas e exploradas pelo Movimento Moderno (BRUNA, 1998). A consciência da necessidade do desenvolvimento da indústria da construção para a solução da questão habitacional, conforme proposto no I CIAM, é um legado perene, que orientou a atividade de vários arquitetos modernos, que deve ser reavaliado na atualidade.

A produção de alguns arquitetos e o reconhecimento de algumas dessas obras veio à luz em função de novas pesquisas. Mas vários arquitetos, ou trabalhos de arquitetos reconhecidos, relativos à habitação social e a industrialização, permanecem pouco desconhecidos. Um desses casos, de arquiteto com uma obra emblemática, e pouco reconhecida, enquanto busca de articulação entre arquitetura moderna e industrialização e racionalização 
da construção, é fornecido por Eduardo Kneese de Mello e o projeto do Conjunto Residencial da Universidade de São Paulo - CRUSP - (1961).

Kneese era um dos arquitetos modernos brasileiro que atuou na produção dos IAP, como no caso do Conjunto Vertical Japurá, já citado, e que sempre defendeu a industrialização das construções.

\begin{abstract}
"Apesar da falta de coordenação e da falta de uma política industrial para a construção brasileira, em contexto no qual a experiência de Brasília é um episódio isolado e mal aproveitado, Kneese seguiu lutando e defendendo a causa da pré-fabricação, utilizando-se e experimentando processos de racionalização e de pré-fabricação que se faziam possíveis." ${ }^{23}$
\end{abstract}

O CRUSP (figura 13) é uma proposta de moradia estudantil, ainda que incorpore uma visão social da inserção do estudante no mundo acadêmico, não pode ser definido strictu sensu como habitação social, mas as questões que integram o seu programa, a visão de projeto e de obra que agrega, permitem correlacioná-lo a produção de habitação social.

Na sua construção foi realizada parcialmente a pré-fabricação de elementos, o que significa que foi a experiência pioneira no Estado de São Paulo em termos de grande escala de associação entre modernismo e industrialização. Os prédios apresentam térreo livre, janelas contínuas e uma organização funcional, procurava-se uma arquitetura vinculada à industria (MONTENEGRO FILHO, 2007). O conjunto já foi bastante descaracterizado na sua construção, porém ainda pode ser encontrado, paradoxalmente, no edifício da Reitoria da USP algumas propostas do projeto original, tais como, fechamento com placas e caixilhos modulados. Os outros edifícios, porém, sofreram mudanças (na obra e posteriormente), como nas fachadas, sendo os

${ }^{23}$ MONTENEGRO FILHO, R.A. de L.(2007); Pré-fabricação e a obra de Eduardo Kneese de Mello. Dissertação (mestrado) - FAU, USP, São Paulo. pg. 157. 
seus vêdos em alvenaria. No projeto, o fechamento da face sul (figura 14), foi proposto com placas coloridas tipo Formiplac. Elas seriam garantidas contra descoloração, o que eliminaria pintura. Em declaração do próprio arquiteto, fica registrada a indignação pelas modificações que ocorreram a revelia do projeto e seus significados, como o fechamento dos térreos, eliminando a idéia original de pilotis e de suas possibilidades espaciais:

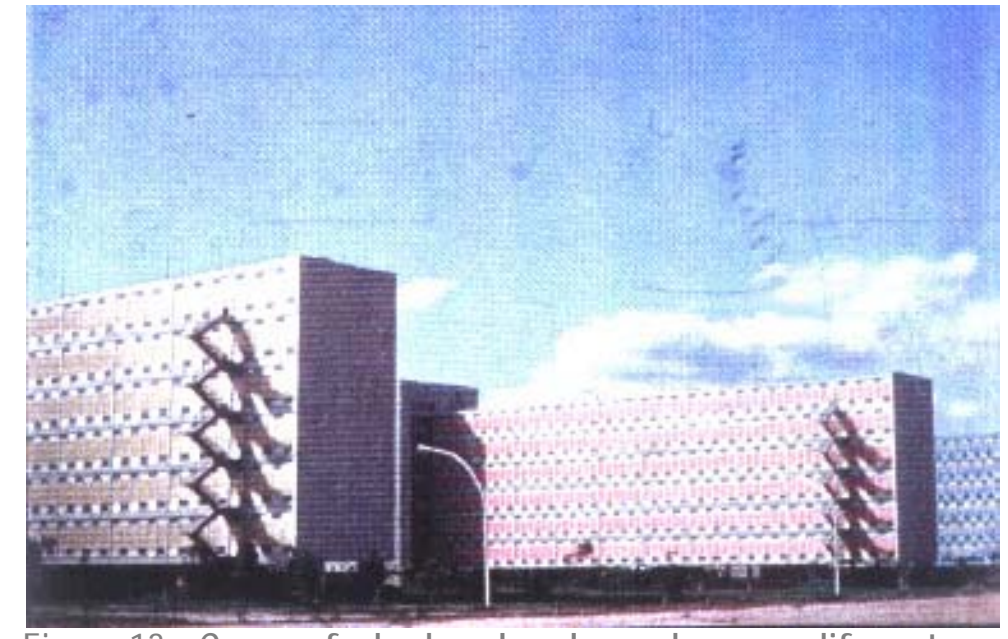

Figura 13 - Crusp - fachada sul e placas de cores diferentes. Fonte: Roberto A. L. Montenegro Filho.

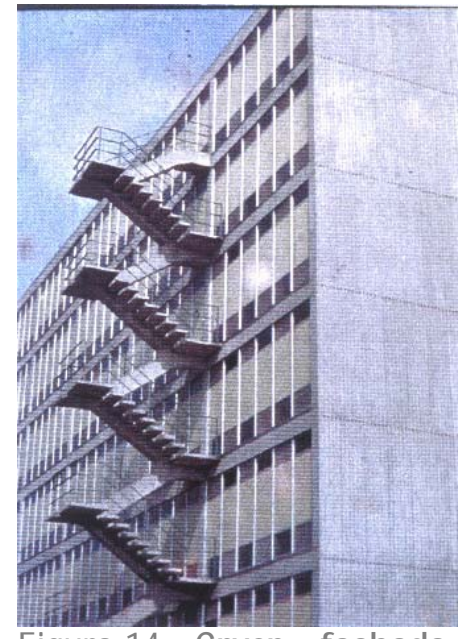

Figura 14 - Crusp - fachada sul original

Fonte: R. A. L. M. Filho.

“(...) Embora aquele prédio tenha sido alterado arquitetonicamente, 0 que eu não concordo, e o térreo que devia ter pilotis, aberto, era a área de sombra, de descanso dos estudantes, tenha sido fechada, mas o espaço aberto está aqui". ${ }^{24}$

O projeto do CRUSP foi válido pela tentativa de se implantar algo préfabricado. Para os doze edifícios pensados inicialmente, o Fundo de Construção da Cidade Universitária, optou por dividir a concorrência em duas partes, sendo que o primeiro lugar (Ribeiro Franco S.A. Engenharia e Construções) logrou o direito de construção de seis blocos com estrutura pré-

\footnotetext{
${ }^{24}$ Kneese de Mello, E. (in Arquiteto) apud MONTENEGRO FILHO, R.A. de L.(2007); Pré-fabricação e a obra de Eduardo Kneese de Mello. Dissertação (mestrado) - FAU, USP, São Paulo. pg. 163.
} 
moldada, tendo o segundo lugar (Servix Engenharia Ltda.) o direito de construir de maneira tradicional (MONTENEGRO FILHO, 2007). Mas, mesmo a empresa que ganhou a concorrência para construir com estrutura prémoldada, parece que não detinha conhecimento para fazê-lo com propriedade, como afirma o próprio Kneese de Mello:

"Mas eu acho que foi uma experiência feita com todos os erros porque não existia uma oficina, não existia equipamento para a préfabricação, era tudo improvisado na própria obra." ${ }^{25}$

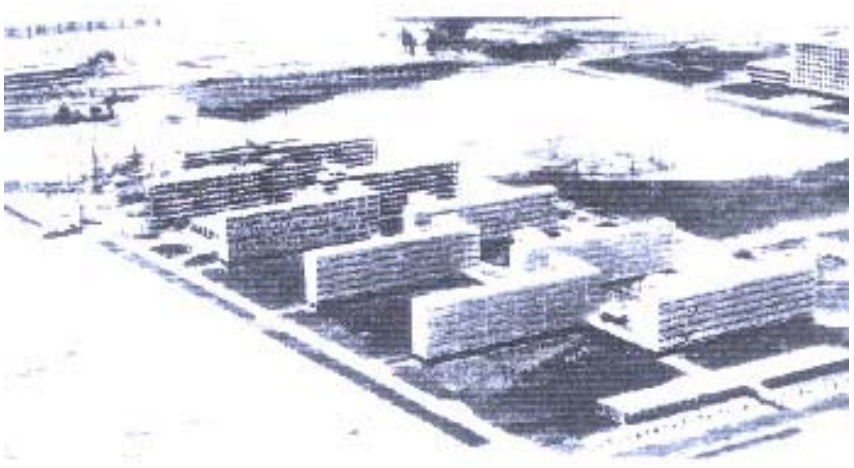

Figura 15 - Foto aérea do Crusp incompleto. Fonte: Roberto A. L. Montenegro Filho.

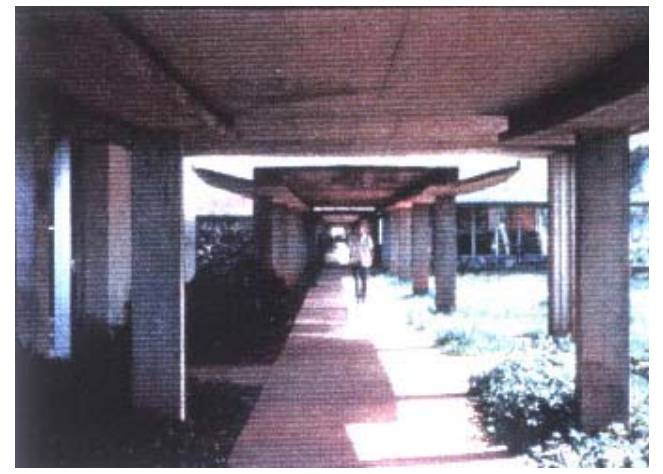

Figura 16 - Pilotis ainda abertos. Fonte: R. A. L. M. Filho.

De todo modo, a experiência do CRUSP não conheceu uma continuidade, nem de forma localizada, nem de forma genérica. Como já visto, um conjunto de programas habitacionais ocorreu no período que se inicia por volta de 1930, e prosseguindo até 1964, são eles: o IAP (Instituto de Aposentadorias e Pensões), a FCP (Fundação da casa Popular, em 1 o de maio de 1946) e o DHP (Departamento de Habitação Popular). Em 1964, incluindo a mudança no sistema de aposentadoria dos trabalhadores é criado o BNH (Banco Nacional de Habitação). As motivações que deram origem ao BNH são de várias ordens como salienta Marta Farah:

\footnotetext{
$25{ }^{25}$ Kneese de Mello, E. (in Arquiteto) apud MONTENEGRO FILHO, R.A. de L. (2007); Pré-fabricação e a obra de Eduardo Kneese de Mello. Dissertação (mestrado) - FAU, USP, São Paulo. pg. 169.
} 
"As iniciativas estatais na área habitacional, por sua vez, mostravamse insuficientes para viabilizar uma produção em massa. Os programas governamentais implementados a partir dos anos 30, no âmbito dos Institutos de Previdência, da Fundação da Casa Popular e de Institutos estaduais e municipais, estavam muito aquém da escala assumida pelo problema habitacional. Por outro lado, no final da década de 50, estes programas haviam praticamente entrado em colapso, diante das taxas inflacionárias, as quais acabaram por comprometer os sistemas de financiamento existentes". ${ }^{26}$

Com o BNH ocorreria uma inflexão na concepção de habitação, que refletiria nos próprios empreendimentos. Buscou-se romper com a paralisia do setor, estimulando-se a construção em larga escala de habitações (FARAH, 1992).

Mas, como sabido, a inflexão ocorrida deu-se em outros sentidos. 0 BNH patrocinou empreendimentos problemáticos, caracterizados pela homogeneidade arquitetônica, pela baixa qualidade construtiva, por estimular a especulação imobiliária, ao criar núcleos habitacionais distantes das malhas urbanas e, por conseguinte, encarecer a infraestrutura urbana, dentre outras questões, afora, talvez coerente com seu perfil de banco, financiar habitação para faixas de renda média e média-alta.

“Entre 1964 e 1986, período marcado pela ação do Banco Nacional da Habitação (BNH), cerca de 4.300.000 habitações foram financiadas pelo Sistema Financeiro da Habitação (SFH), as quais representam aproximadamente $28 \%$ da produção habitacional no período considerando-se inclusive, a autoconstrução e os barracos da favela". ${ }^{27}$

\footnotetext{
${ }^{26}$ Farah, Marta Ferreira Santos (1992); Tecnologia, Processo de Trabalho e Construção Habitacional. Tese (doutorado) - FFLCH/ USP - São Paulo. Pg. 160.

${ }^{27}$ Melo, Marcos André B.C. Estruturação intra-urbana, regimes de acumulação e sistemas financeiros da habitação: Brasil em perspectiva comparada. Espaço e Debates, 31, p.37-51, 1990. pg. 50.
} 
O banco teve um período inicial, de 1964 a 1969, de legitimidade do novo governo. A população até $3 \mathrm{s.m}$. de renda era o alvo preferencial de um governo militar e dos agentes promotores do BNH, "demonstrando" preocupação social e principalmente com moradias sociais (CASTRO, 1999).

Através da grande quantidade de construção, pôde-se ter experiências variadas sobre habitação popular, e ainda nos anos 1970, tentou-se a incorporação de novos métodos construtivos ao canteiro de obra (FARAH, 1992).

“(...)Tal iniciativa se deu no âmbito da promoção estatal, através da construção de grandes conjuntos habitacionais para a população de baixos rendimentos. No início da década, registraram-se algumas experiências neste sentido, particularmente em São Paulo e no Rio de Janeiro. Tais experiências, no entanto, constituíram iniciativas paralelas à orientação então predominante na política brasileira, a qual, ao privilegiar a geração de empregos pelo setor, defendia a manutenção da base técnica tradicional na atividade de construção" ${ }^{28}$

Em 1971 o BNH foi transformado em banco de segunda linha e passou a atuar na retaguarda do sistema vinculado, como empresa pública, ao Ministério do Interior (Lei n. 5.762/71) (CASTRO, 1999). E, em 1974, com os primeiros sinais de desaceleração da economia brasileira, Farah (1992):

"Neste momento, ganharam importância, no âmbito dos financiamentos concedidos pelo SFH, os programas de interesse social, promovidos pelo Estado, os quais consistem predominantemente em conjuntos habitacionais construídos por iniciativa do poder público". ${ }^{29}$

\footnotetext{
${ }^{28}$ Farah, Marta Ferreira Santos (1992); Tecnologia, Processo de Trabalho e Construção Habitacional. Tese (doutorado) - FFLCH/ USP - São Paulo. Pg. 161.

${ }^{29}$ idem. Pg. 169.
} 
Entretanto, mesmo após a criação do BNH houve experiências importantes como as patrocinadas pela CACEX (Cooperação Científica e Técnica), cujos projetos de empreendimentos habitacionais eram permeados, tanto pelas questões de organização espacial, como pelas questões relativas a industrialização da construção, objetivando um menor custo das unidades habitacionais. Parte dos pressupostos dos empreendimentos foram alcançados e parte permaneceu em projeto.

“(...) o mercado acaba invalidando esforços de economia no espaço, como ocorreu no Conjunto da CECAP "Zezinho Magalhães" em Guarulhos, onde a intenção era construir habitações para uma parcela de menor poder aquisitivo. A ocupação foi distinta e em muitas unidades descaracterizou alguns pressupostos do projeto". ${ }^{30}$

No caso, objeto deste trabalho, o Conjunto "Zezinho Magalhães" foi concebido e construído no apogeu do debate sobre as condições em que se daria o desenvolvimento nacional, e como decorrência de que forma se desenvolveria a industrialização e, em particular, a industrialização da construção civil no país.

0 pano de fundo deste processo, que se iniciou com o governo Vargas, em 1930, conheceu a partir da segunda metade da década de 1950 com a política desenvolvimentista uma forte inflexão, expressa no Plano de Metas do governo Jucelino Kubstcheck (1956-61). O primeiro grande trabalho de planejamento econômico seria realizado pela Comissão Mista Brasil-Estados Unidos (1951/53) e o segundo pelo Grupo Misto BNDE-CEPAL (1953/55). Estruturando-se a partir dessas experiências anteriores e tendo como lastro conceitual as elaborações da Comissão Econômica para o Desenvolvimento da América Latina - CEPAL - O Plano de Metas parecia que iria tornar realidade às propostas e anseios anteriores e surgia para os intelectuais progressistas

${ }^{30}$ GITAHY, M. L. C.; PEREIRA, P. C. X. (org.) (2002) O complexo industrial da habitação econômica moderna, 19301964. Editora RiMa. São Carlos, São Paulo. Pág. 46. 
como um meio concreto de retirar o país do atraso tecnológico, industrial e político, dando consistência às políticas industriais e às propostas, no caso da arquitetura, que se espelhavam na industrialização.

Segundo Guido Mantega o Plano de Metas:

\begin{abstract}
"confirmava as áreas prioritárias da economia brasileira a serem contempladas com o maior volume de recursos do Estado, já indicadas desde a Comissão Mista Brasil-Estados Unidos. Dessa forma, energia, transporte e insumos básicos continuavam nevrálgicos para 0 prosseguimento da acumulação industrial. Porém o Plano de Metas distinguia-se dos seus fac-símiles à medida que punha em prática um extenso programa de incentivos ao setor privado, combinado com a atuação das instituições e empresas estatais, resultando na mobilização de um volume inédito de recursos." ${ }^{31}$
\end{abstract}

O desenvolvimentismo do governo Kubstcheck talvez teve em Brasília a sua maior expressão. Nova cidade, novo urbanismo consubstanciando as promessas de modernização econômica e modernismo social. Entretanto, o Plano de Metas engatilhou uma série de problemas econômicos e sociais que tiveram o desenlace no golpe militar de 1964, encerrando um período, marcado pelos governos de Jânio Quadros e J oão Goulart.

Após o golpe de 1964, e mesmo um pouco antes, surgiram críticas sobre a correção da concepção do desenvolvimento brasileiro em repetir o processo histórico dos países europeus e dos Estados Unidos e mesmo críticas ao apoio, por parte de intelectuais progressistas, ao desenvolvimentismo que compensava as insuficiências de uma política social com o populismo político que mantinha os traços autoritários da sociedade brasileira.

Ou seja, do ponto de vista econômico, no Brasil as estruturas produtivas modernas eram implantadas, mas não substituíam as arcaicas na

\footnotetext{
31. Mantega, Guido, A Economia Política Brasileira, p.73.
} 
sua totalidade, combinavam-se com estas, e em muitos casos dependiam delas. A arquitetura moderna brasileira e seus vínculos com o processo de modernização foi criticada por alguns arquitetos, basicamente Sérgio Ferro e Rodrigo Lefèvre, por desconhecer a realidade do país, por se basear em propostas de industrialização irreais, propostas de laboratório segundo Lefèvre e, do ponto de vista social, por penalizarem o trabalhador no canteiro, que tinha que suprir as carências tecnológicas da produção. ${ }^{32}$

Neste Contexto, em 1967, deu-se o início da construção do “Conjunto Habitacional Zezinho Magalhães Prado" (ver capítulo 3). Os seus autores eram fiéis ao programa desenvolvimentista e não aceitavam a hipótese de que 0 desenvolvimento do país era diferenciado dos modelos anteriores. O Conj unto foi concebido como um representante da aplicação da industrialização e préfabricação em conjuntos habitacionais. Fica claro na sua proposta que os arquitetos deveriam auxiliar o desenvolvimento nacional, estimulando no seu setor, o da construção, a modernização industrial, conforme propunha Artigas.

Localizado em Guarulhos (grande São Paulo), o conjunto é formado por 10 (dez) condomínios totalizando 4.680 apartamentos e conforme o censo 2000, a sua população é de 15.226 habitantes.

Ele evidencia uma orientação arquitetônica moderna e demonstra uma construção integrada ao contexto da época, privilegiando uma parte dos ideais, ainda que não fossem mais hegemônicos como na década anterior, enfocando a industrialização e a pré-fabricação do sistema construtivo.

"A introdução de novos materiais e componentes na produção de edificações teve inicialmente uma difusão restrita. Mas já assinalava a incorporação pelo canteiro de obras de componentes industrializados,

32 Para as discussões sobre as concepções econômicas e políticas dos anos 1950 e 1960 ver Mantega, Guido, A Economia Política Brasileira. Para o debate arquitetônico ver Buzzar, M. A. Rodrigo Brotero Lefèvre e a Idéia de Vanguarda, Ferro, Sérgio, Arquitetura Nova. 
tendência que seria reforçada a partir da expansão das atividades de construção no final dos anos 60". ${ }^{33}$

Com a industrialização a dificuldade da construção passou para 0 gerenciamento do complexo da construção, controlando a formação e o fluxo de capitais, investindo em várias áreas, tais como, indústria de materiais, pesquisa, normatização e formação tecnológica.

O Conjunto Habitacional Zezinho Magalhães Prado faz parte das estatísticas do BNH, que financiou o conjunto juntamente com a CECAP, de 1967 até 1981, como já visto anteriormente (citação 27), nesse período o BNH financiou cerca de 4.300.000 habitações.

${ }^{33}$ Farah, Marta Ferreira Santos (1992); Tecnologia, Processo de Trabalho e Construção Habitacional. Tese (doutorado) - FFLCH/ USP - São Paulo. Pg. 153. 


\section{CAPÍTULO 3}

\section{A CECAP e o Conjunto Habitacional Zezinho Magalhães Prado.}

O Conjunto Habitacional Zezinho Magalhães Prado foi escolhido como estudo de caso desta dissertação por ser um ícone da Arquitetura Moderna no Brasil. Os conceitos inovadores que foram aplicados e sua forma revelam alguns índices de industrialização na construção. Neste capítulo pretende-se mostrar a realidade das questões que envolveram essa grande obra iniciada no final da década de 1960 e concluída em 1981, que teve como protagonistas expoentes da arquitetura nacional e do debate político-cultural.

Para a análise feita, nos valemos dos conceitos apresentados inicialmente e da discussão sobre a arquitetura moderna em geral e da arquitetura moderna brasileira e suas relações com a política e 0 desenvolvimentismo apresentada nos capítulos anteriores.

Um dos nomes pelo qual o Conjunto é conhecido é Parque CECAP. Iniciamos a nossa análise justamente pela explicitação deste órgão estadual, essencial para a intelecção do processo, a CECAP.

\section{A CECAP}

A CECAP (Caixa Estadual de Casas para o Povo) autarquia ${ }^{1}$ criada em 1949, por Adhemar de Barros (FICHER, 1972) para desenvolver programas de política habitacional no Estado de São Paulo, em seus primeiros 18 anos de existência havia construído 40 (quarenta) habitações populares (PENTEADO, 2007).

A CECAP era um órgão da administração pública com certa autonomia financeira, cujo objetivo era construir e vender casas para os trabalhadores sindicalizados. Os critérios de habilitação para as moradias eram: menor

\footnotetext{
${ }^{1} \mathrm{Na}$ administração pública brasileira, uma autarquia é uma entidade auxiliar da administração pública estatal autônoma e descentralizada. Seu patrimônio e receita são próprios, porém, tutelados pelo Estado. O Decreto-Lei no 200 de 1967, no seu artigo 5o, inciso I, define autarquia como "Serviço autônomo criado por lei, com personalidade jurídica de direito público, patrimônio e receita próprios, para executar atividades típicas da Administração Pública, que requeiram para seu melhor funcionamento gestão administrativa e financeira descentralizada" (http:// pt. wikipedia.org).
} 
salário, maior número de filhos menores, ser sindicalizado, tempo de sindicalização e maior tempo na Grande São Paulo (REVISTA DESENHO 4, 1972).

Em 1966 Zezinho Magalhães Prado é empossado superintendente da autarquia (PENTEADO, 2007) ${ }^{2}$ e implementaria uma dinâmica inusitada, para qual concorreu a nomeação como seu assessor o arquiteto Ruy Gama (PUNTONI, 2007) $^{3}$. Este teve influência na decisão de chamar os arquitetos Vilanova Artigas e Fábio Penteado, que posteriormente chamariam Paulo Mendes da Rocha, para coordenarem o projeto de um grande Conjunto Habitacional em Guarulhos. Note-se que naquele momento, em plena ditadura militar, Artigas já era uma personalidade política de esquerda reconhecida, que não havia ainda sido cassado como professor da FAUUSP, mas que era alvo de inquisições por parte do aparelho repressivo do Estado.

Em 18 de dezembro de 1975 a CECAP tem a sua nomenclatura alterada para Compainha Estadual de Casas Populares e é desativada em 1980. Assim todos os direitos foram passados para a Companhia do Desenvolvimento Habitacional e Urbano (CDHU), sendo lá encontrados os dados remanescentes daquela época.

\section{Guarulhos e o Bairro Parque CECAP}

O Conjunto Habitacional Zezinho Magalhães Prado, ou Parque CECAP, pela sua grandiosidade, acabou dando nome ao bairro (Parque CECAP) está localizado em Guarulhos, no nordeste da Região Metropolitana de São Paulo (figura 17), sendo um dos 39 municípios que a integra. Situa-se no eixo Rio/ São Paulo, a 19km da capital (ISSAC, 2007).

\footnotetext{
${ }^{2}$ Entrevista de Fabio Penteado a autora em 09/ 03/ 2007.

${ }^{3}$ Entrevista de Vespasiano Puntoni a autora em 17/ 07/ 2007.
} 


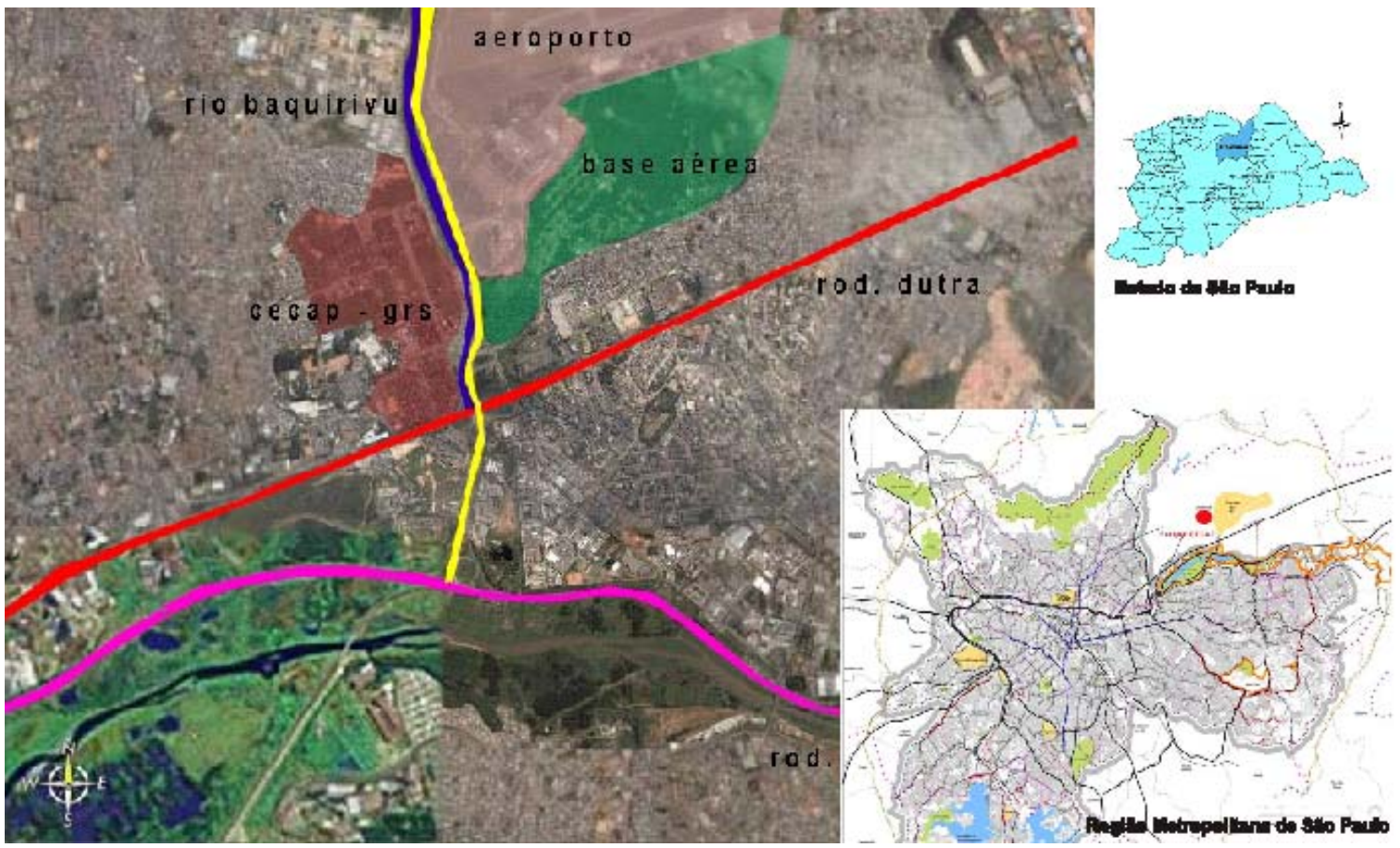

Figura 17 - Localização do Conjunto Habitacional Zezinho Magalhães Prado/Parque CECAP; Fonte: Solimar Mendes Issac.

“Estrategicamente posicionado entre o eixo Rio/SP, o município de Guarulhos foi escolhido para a implantação de equipamentos de impacto regional tais como: o Aeroporto Internacional de São Paulo Guarulhos (inaugurado em 1985 e com a terceira pista em fase de projeto), Rodoanel, Dryport, o Parque Ecológico do Tietê e o Parque Estadual da Cantareira". ${ }^{4}$

Pela figura 17, vemos que a área do terreno destacada (cor ferrugem), faz divisa com o Rio Baquirivú, o Aeroporto Internacional de Cumbica e a Base Aérea, além de ter a Rodovia Presidente Dutra (figura 17 - vermelho) e a Avenida Perimetral (figura 17 - amarelo) margeando-a e um pouco mais afastada a Rodovia Ayrton Senna da Silva (figura 17 - rosa). Cabe registrar que à época o Aeroporto (enquanto equipamento de uso civil) era uma possibilidade e a Avenida Perimetral e a Rodovia Ayrton Senna da Silva não haviam sido implantadas.

${ }^{4}$ ISSAC, S. M. (2007); Parque CECAP Guarulhos: transformação urbana. Dissertação (mestrado) - FAU, USP, São Paulo. p. 15. 


\section{Área do Conjunto Habitacional Zezinho Magalhães Prado}

O terreno era de propriedade da Caixa Econômica do Estado de São Paulo (CEESP) (figura 18) com cerca de $1.780 .000 \mathrm{~m}^{2}$. Em 23 de agosto de 1967 houve um processo de desapropriação amigável movido pela CECAP contra a CEESP, originando a transcrição de no 19.403 (ISSAC, 2007).

A área foi utilizada em sua totalidade para o projeto inicial do conjunto habitacional, porém, como será visto a diante, este não foi construído na sua totalidade. Na parte do terreno à direita da Rodovia Presidente Dutra não houve qualquer tipo de construção, e na área à esquerda da rodovia foram construídos parte dos blocos habitacionais e parte dos aparel hos coletivos.

Sylvia Ficher, em 1972, estagiária da CECAP, fez um relato muito interessante sobre o terreno, corroborando e reforçando as bases de projeto que sedimentavam a implantação do conjunto e a implantação das edificações sobre pilotis:

“A área do terreno é de 180ha e sua conformação topográfica apresenta relevo pouco acentuado, predominando a várzea do rio Baquirivu, afluente do principal curso d'água da Região Metropolitana que é o Tietê. A natureza do terreno particularmente das camadas superficiais turfosas, aliada à condição do relevo, foram dados muito importantes para elaboração do plano urbanístico e dados técnicos da análise do solo influenciaram sobremaneira às técnicas e construtivas dos edifícios previstos. Todos os edifícios habitacionais se apóiam em pilotis, do que resulta melhor condição técnica em função do tipo do solo e maiores vantagens econômicas, liberando a camada superficial para a circulação dos pedestres e recreação infantil" . ${ }^{5}$

${ }^{5}$ FICHER, S. (1972); Subsídios para um Estudo do Conjunto Habitacional Zezinho Magalhães Prado. Monografia de conclusão de curso (TCC). FAU-USP. 


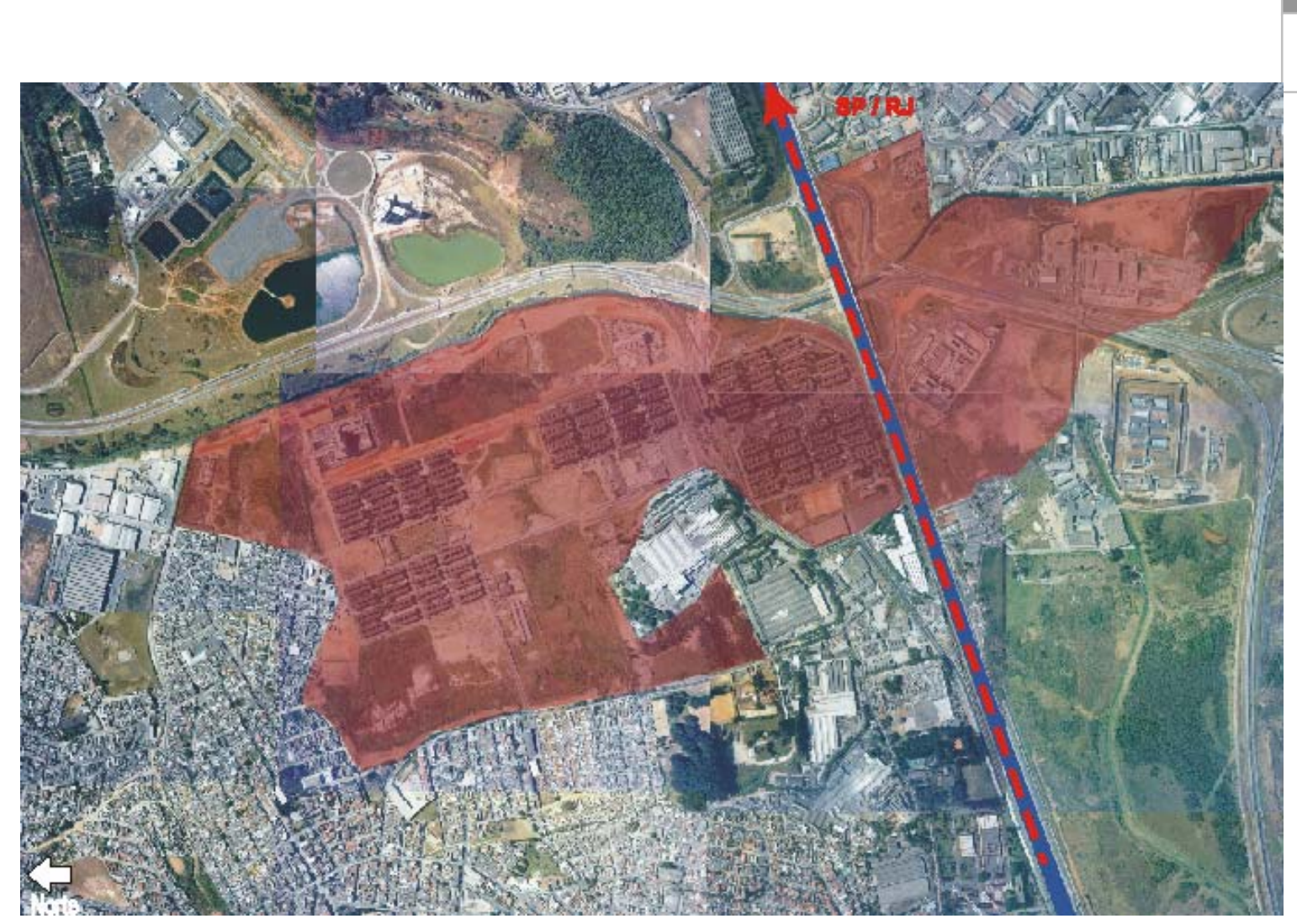

Figura 18 - Matrícula de $1.780 .000 \mathrm{~m}^{2}$ - Terreno Incial CEESP;

Fonte: Solimar Mendes Issac.

\section{Dados de Projeto}

No Debate sobre o Conjunto realizado na FAUUSP em 1968, e publicado em 1972 na Revista Desenho 4, há uma descrição sintética do projeto, conforme a tabela 01 , que se aplica apenas à primeira fase, pois foi uma obra muito longa que passou por transformações em cada fase da obra. 0 superintendente, quando do debate, havia sido mudado em função do falecimento de Zezinho Magalhães Prado, no seu lugar entrou Juvenal J uvêncio.

Como pode ser observado na tabela 01, além dos arquitetos citados acima, existe a participação de muitas pessoas envolvidas no processo de projeto e de construção. 
Tabela $01^{6}$ - Dados de projeto do Conjunto Habitacional Zezinho Magalhães Prado.

\begin{tabular}{|c|c|}
\hline Descrição & Projeto 1a Fase \\
\hline Moradias & 10.680 unidades \\
\hline População prevista & 55.000 habitantes \\
\hline Terreno & $180 \mathrm{ha}$ \\
\hline Descrição habitações & $\begin{array}{l}\text { edifícios de } 3 \text { andares sobre pilotis, } \\
\text { organizados em Freguesias (32 edifícios) }\end{array}$ \\
\hline Serviços Coletivos & $\begin{array}{l}8 \text { grupos escolares, } 3 \text { ginásios, } \\
1 \text { escola industrial, } 1 \text { hospital geral, } \\
\text { Pronto-socorro ambulatório, } \\
\text { Centro de saúde, Posto de puericultura, } \\
\text { Estádio para } 10.000 \text { pessoas, } 2 \text { cinemas, } \\
\text { Hotel, Teatro, Comércio próprio, Igreja, } \\
\text { Clube, Entreposto de Abastecimento, } \\
\text { Caixa d'água e Gasômetro. }\end{array}$ \\
\hline Coordenação do Proj eto & $\begin{array}{l}\text { J oão Vilanova Artigas } \\
\text { Fábio Penteado } \\
\text { Paulo Mendes da Rocha }\end{array}$ \\
\hline $\begin{array}{l}\text { Arquitetos que trabalharam } \\
\text { no Projeto }\end{array}$ & $\begin{array}{l}\text { Arnaldo Martino } \\
\text { Renato Nunes } \\
\text { Ruy Gama } \\
\text { Giselda Cardoso Visconti } \\
\text { Geraldo Vespasiano Puntoni }\end{array}$ \\
\hline Estudos Sócio-econômico & CEMACO (Eugênia Paesani) \\
\hline $\begin{array}{l}\text { Pesquisa do Sistema } \\
\text { educacional }\end{array}$ & $\begin{array}{l}\text { Celso Lamparelli } \\
\text { Maiumy Souza Lima } \\
\text { Alice Gonzaga }\end{array}$ \\
\hline Sistema de Abastecimento & PROAGRI \\
\hline Cálculo Estrutural & $\begin{array}{l}\text { José Carlos Figueiredo Ferraz } \\
\text { J osé Antônio Del Nero } \\
\text { J osé Almeida Castanho }\end{array}$ \\
\hline $\begin{array}{l}\text { Engenharia Hidráulica e } \\
\text { Sanitária }\end{array}$ & PLANIDRO \\
\hline $\begin{array}{l}\text { Instalações Elétricas e } \\
\text { Hidráulicas }\end{array}$ & Henrich Zwilling e Cia. Ltda \\
\hline $\begin{array}{l}\text { Orçamento e programação da } \\
\text { obra }\end{array}$ & L. Falcão Bauer Ltda \\
\hline Geologia & Stelavio Ranzini \\
\hline
\end{tabular}

\footnotetext{
${ }^{6}$ Não estão nesta tabela todos os nomes das pessoas que trabalharam no projeto e sim as pessoas que foram contratadas para o projeto, muitos colaboradores eram funcionários públicos transferidos do extinto DOP para a CECAP, dentre eles, Ruy Gama, Giselda Visconti e Geraldo Vespasiano Puntoni.
} 
A idéia inicial do conjunto foi fazer moradias agrupadas em 6 setores denominados freguesia, sendo que cada setor teria um raio de $150 \mathrm{~m}$, uma escola e pequeno comércio para o cotidiano, portanto pode ser verificada a idéia moderna de unidade de vizinhança, ou superquadra. O serviço de transporte proposto atravessa o conjunto de forma tal, que passa igualmente a $150 \mathrm{~m}$ de cada moradia.

Cada lâmina é composta por 3 andares sobre pilotis, sendo o bloco formado por dois edifícios interligados por um jardim sombreado onde se localizam as escadas de acesso, cada uma servindo a 12 apartamentos.

O apartamento, com $64 \mathrm{~m}^{2}$ de área, teria como característica uma planta de uso flexível, a fim de permitir a cada morador várias hipóteses de adaptação, segundo os hábitos ou o tamanho da família (FICHER, 1972). 0 equipamento hidráulico e de serviços do apartamento está concentrado em uma faixa do bloco que compõe a cozinha, o banheiro e a lavanderia.

Alguns dos dados acima podem ser vistos na implantação no terreno (figura 19) mostrada a seguir, tais como os blocos de edifícios e os serviços coletivos.

Para melhor entendimento, seguir a legenda: (1) Habitação (azul); (2) Comércio da Freguesia (amarelo); (3) Comércio Central (magenta); (4) Centro Educacional (rosa); (4A) Ensino Técnico (rosa); (5) Hospital (cinza); (5A) Centro de Saúde (cinza escuro); (6) Igreja (Iaranja); (7) Teatro de Arena (roxo); (8) Esporte (verde); (9) Centro de Abastecimento (verde claro); (10) Piscina (roxo escuro); (11) Caixa d'água (vermelho). 
4 A r. envino tbenico: 5 , hospital 5 A - centro de saúde; 6 . igrejo; 7 . teatro de oreno; 8 - esporte; 9 . centro de obastecimento; 10 . pisgino; 11 . ceixa d'águc

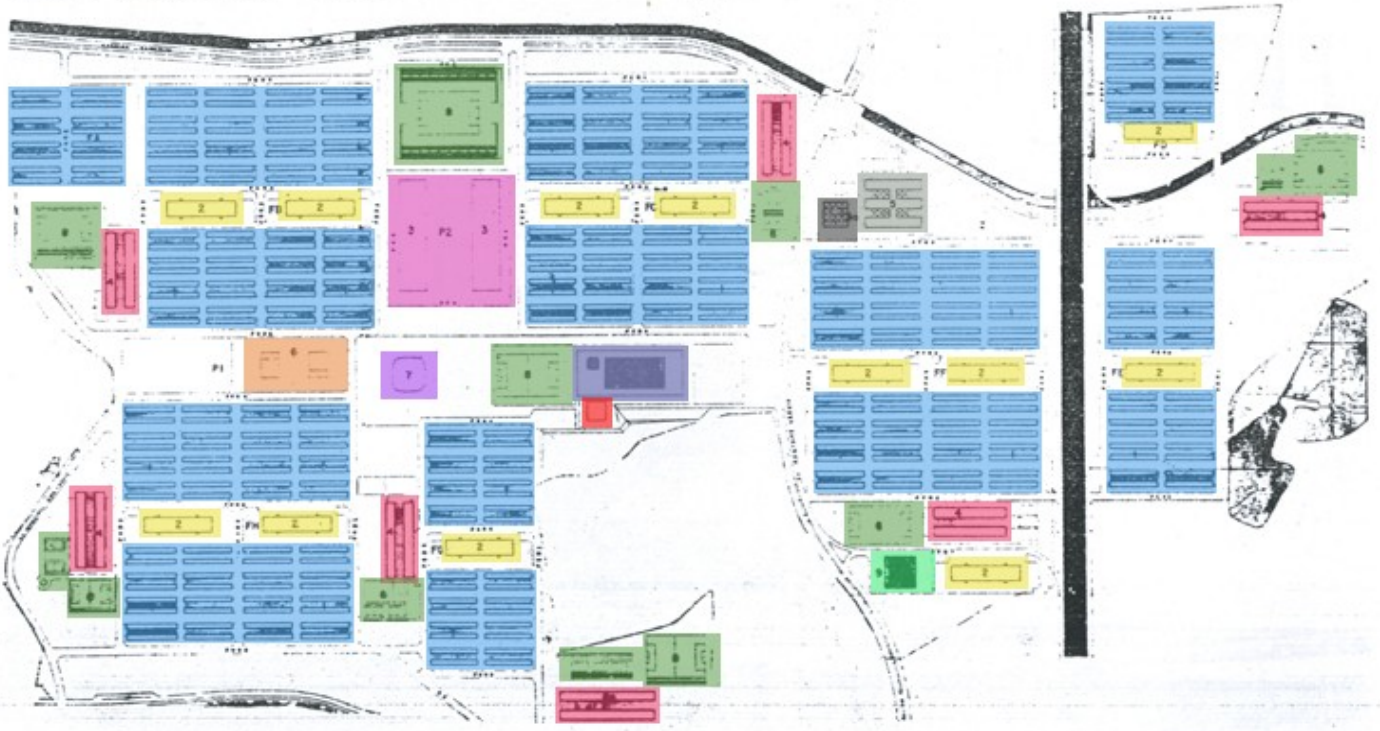

Figura 19 - Implantação do todas as construções no projeto de 1967. Fonte: Revista Desenho 4.

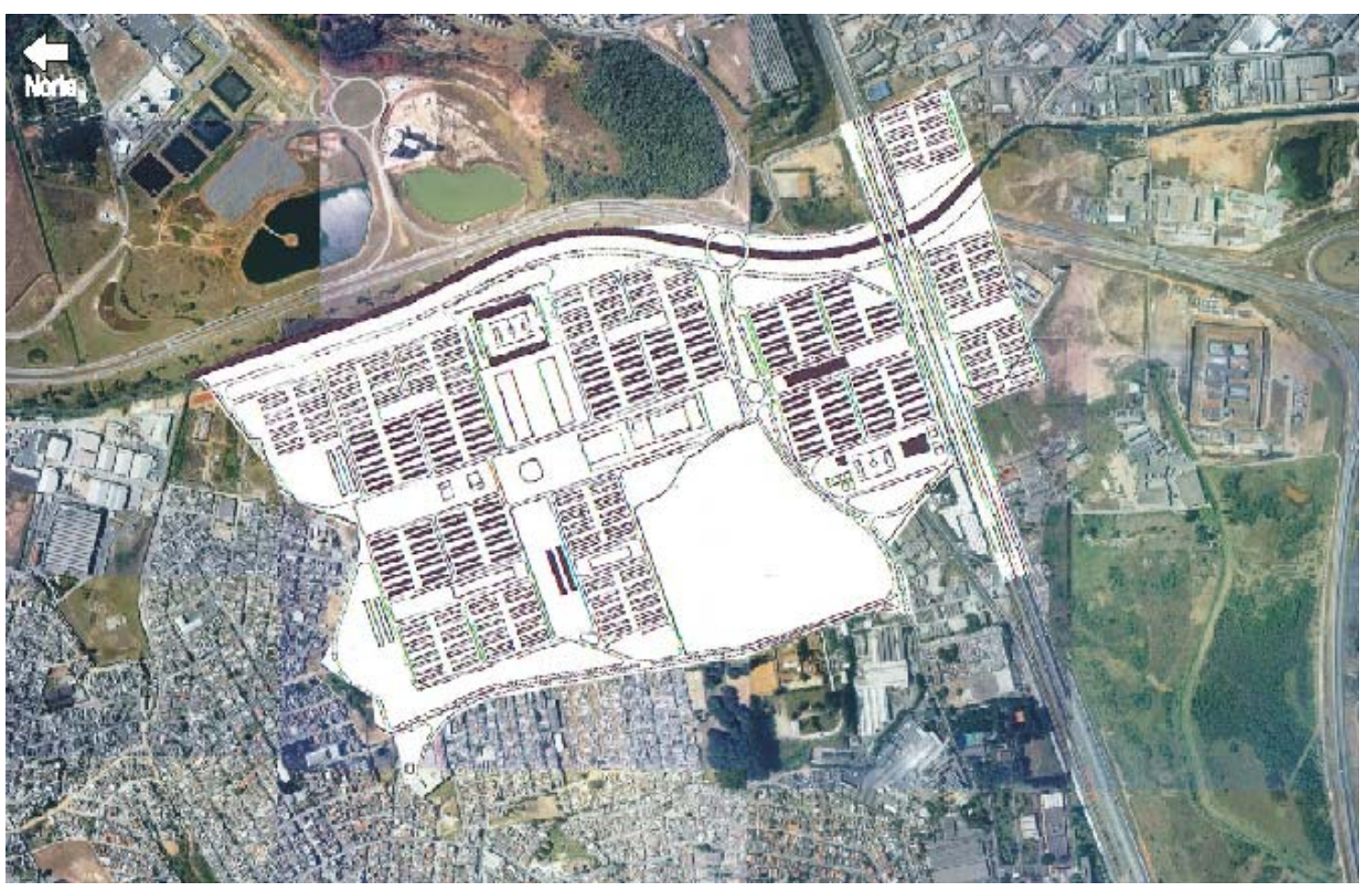

Figura 20 - Implantação do projeto completo de 1967 na malha urbana atual de Guarulhos. Fonte: Solimar Mendes Isaac. 
Na figura 20, podemos ver como seria a implantação do projeto na malha urbana atual de Guarulhos, caso o conjunto tivesse sido implantado na sua totalidade.

\section{Conceitos Aplicados ao Projeto}

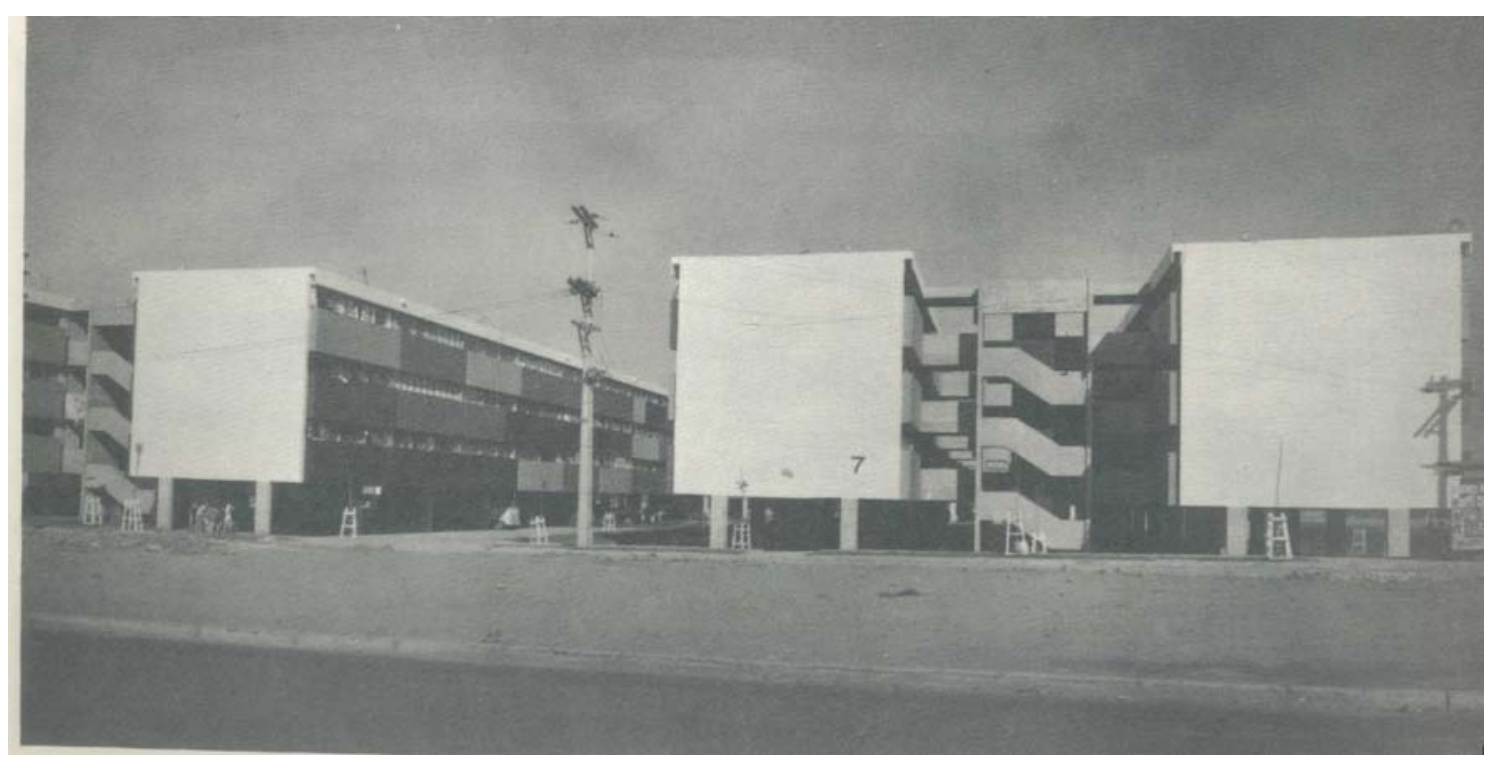

Figura 21 - Edifícios da primeira fase de construção.

Fonte: Revista Desenho 4.

Como podemos ver na figura 21, algumas das soluções utilizadas são bem nítidas, configurando o conjunto, tais como os pilotis, edifícios em forma de lâminas em quatro pavimentos (térreo mais três pisos), janelas horizontais que cortam toda a fachada, o bloco sem cobertura aparente, distância entre edifícios respeitando a entrada de raios solares de forma adequada em todos apartamentos. Nessas soluções transparecem conceitos claros da arquitetura moderna, porém outros conceitos, não tão explícitos, são também observados, como a planta das unidades, de $64 \mathrm{~m}^{2}$ (figura 26), totalmente racionalizada com o mínimo de espaço possível perdido para a circulação, paredes internas na forma de divisórias com 9 centímetros de espessura, os 
armários como caixas que avançam nas fachadas, possibilitando maior espaço interno.

Um dos objetivos que foi mais perseguido em toda a obra, talvez o fio direcionador de tudo, que deveria validar o paradigma da industrialização e da racionalização da construção civil, foi à redução do custo da obra. Como diz Ficher ${ }^{7}$, foi aplicado em vários pontos diferentes, como por exemplo:

- redução de consumo de concreto: (-37\%) e espessura da parede 9,4cm;

- redução nos condutos d'água: pois foi escolhido a entrada direta da água da rua, sem caixas d'água nos blocos;

- solução racional dos pisos: sem contrapiso;

- eliminação de baldrames: a amarração dos pilares foi feita direto no primeiro pavimento;

- caixilhos: grande quantidade de caixilhos da mesma especificação, e;

- armários: necessário apenas a colocação de portas.

No Debate realizado na FAUUSP em 1968, os arquitetos autores expuseram o projeto e explicaram alguns dos conceitos usados. Abaixo um trecho da explanação de Ruy Gama, que nesse processo cumpriu um papel intermediário entre a CECAP e os arquitetos:

“A CECAP então se propôs a elaborar um projeto para aproveitamento de área no Município de Guarulhos, próximo ao aeroporto de Cumbica que pudesse capitalizar toda experiência obtida no nosso trabalho anterior, contando ainda com arquitetos de fora do serviço público e apresentar uma solução que pudesse realmente estar de acordo com

${ }^{7}$ FICHER, S. (1972); Subsídios para um Estudo do Conjunto Habitacional Zezinho Magalhães Prado. Monografia de conclusão de curso (TCC). FAU-USP. 
as necessidades dos trabalhadores da região metropolitana de São Paulo, e que pudesse expressar aquilo que fosse possível obter de melhor em matéria de projeto e de planejamento". ${ }^{8}$

Nesse trabalho, um dos diferenciais foi mesmo a relação entre projeto e planejamento. O planejamento racional informa o projeto e organiza a relação entre o projeto (concepção) e obra (produção), tornando a prática do arquiteto, ou do construtor em termos genéricos, uma prática racional, quase científica, extirpando os aspectos intuitivos do projeto e da obra. Cada detalhe foi trazido ao papel antes de ser colocado em prática, o que assegurou um resultado superior em relação à maioria das construções de conjuntos habitacionais.

Um dos coordenadores gerais do projeto, Fábio Penteado, que em função das limitações que Artigas acabou sofrendo por conta de sua militância de esquerda, acabou exercendo o papel de gerenciador por parte dos autores, expôs no Debate o conceito urbano-paisagístico do projeto:

"O conceito básico adotado no plano, foi à abertura de áreas, as mais generosas possíveis e nos entornos desta área a colocação, de maneira compacta, daquilo que no nosso projeto passou a se chamar de freguesia. Resulta num conjunto de soluções apoiadas nos 150m. Estes $150 \mathrm{~m}$ resultam num centro de abertura da freguesia para um espaço de comércio e outras utilizações, cada uma delas por sua vez, se comunica com um grande espaço aberto que é a área para onde convergem todos os movimentos". ${ }^{9}$

Outro trecho importante do debate é quando Paulo Mendes da Rocha expõe a preocupação com os moldes brasileiros de habitação, mas, sobretudo, a preocupação com a proposta construtiva e as suas motivações:

\footnotetext{
${ }_{9}^{8}$ Revista Desenho no 04 - Debate CEB 1968. 
“Um dos aspectos mais interessantes é o problema ligado à viabilidade do projeto em relação à sua qualidade como casa, como habitação de uma faixa de população de determinado poder aquisitivo, limitada e conhecido (...) o projeto foi então visto de forma a ser executado dentro de uma técnica de concreto armado com perspectiva de aproximação à pré-fabricação, e da pré-moldagem (...) em relação aos edifícios em si, o projeto foi pensado de maneira que pudesse dar uma condição de habitabilidade e que fosse ao mesmo tempo razoável em relação aos costumes, ao que é molde do povo brasileiro." 10

A “aproximação" com a pré-fabricação e a pré-moldagem, isto é, com processos que implicam na industrialização da construção, reafirmando a prática racional do fazer arquitetônico, aparecem possibilitando, em termos técnicos, um morar mais qualificado (habitabilidade), irmanado com o morar em termos subj etivos (costumes do povo brasileiro).

Articulando o "fio condutor" Paulo Mendes da Rocha fez uma declaração sobre a questão da economia geral da obra, que ganha o status de economia social:

"O problema do custo, da economia, da viabilidade de um projeto como este, apresenta aspectos da ordem do que seria uma economia social, no caso. Nós poderíamos dar a vocês dados, que se encontram no corrente dos projetos racionalmente feitos, porque são fatias dentro da exigüidade da área, o problema da casa de $70 \mathrm{~m}^{2}$, o volume de concreto armado, a técnica adotada, tudo enfim me parece já bastante discutido e conhecido por nós". ${ }^{11}$

É importante observar como os "projetos racionalmente feitos" articulam uma "economia social". Ainda que o trecho não cite, mas

${ }^{10}$ Revista Desenho № 04 - Debate CEB 1968.
${ }_{11}$ idem. 
ordenando estas noções com as presentes nas outras declarações, fica claro, que o projeto do Conjunto é apresentado como a expressão do paradigma de um modo de ver a racionalidade produtiva, vinculada aos processos industriais, propiciando melhorias sociais.

No trecho, especificamente, além da questão do espaço da unidade, fica subentendida a opção em propor unidades multifamiliares, e não várias unidades habitacionais unifamiliares, em função do ganho no espaço físico, ou seja, economia do tamanho do terreno. Isto porque, já naquela época, os efeitos da especulação imobiliária já se faziam sentir na Grande São Paulo. A preocupação social vinha também por ser um projeto pré-fabricado, ou seja, com possibilidade de ser reproduzido em grande escala.

No debate, Artigas também discorreu sobre o assunto da economia versus a opção pela industrialização. Note-se que esta discussão é fundamental, pois no debate entre Artigas e companheiros frente às posições de Sérgio Ferro e Rodrigo Lefèvre, devia-se comprovar que a proposta de execução do empreendimento a partir de pré-moldados de concreto havia de se mostrar competitiva em relação ao uso de técnicas tradicionais. Assim Artigas afirmou:

"Digamos que fosse colocado para nós, o problema de um apartamento de $64 \mathrm{~m}^{2}$, representa em área, um tamanho quase exagerado com relação à média universal que se dá para uma família de 5 pessoas. Nas condições brasileiras eu acredito que não deva ser menor porque certamente haverão acumulações maiores numa boa parte dos apartamentos. Mas atingir um preço que pudesse ser acessível em termos de prestação, corresponderia a propor essas estruturas de construção com tal critério de escolha de preço, o que agrava o problema de maneira extraordinária. Foi preciso propor um processo de construção no qual podemos fazer este edifício com espessuras médias de $9 \mathrm{~cm}$ de concreto armado; foi preciso também modificar a estrutura de fornecimento de água, foi preciso ir ao 
aspecto que nos levaram a projetar um tipo de fogão e ver como era possível arranjar uma geladeira". ${ }^{12}$

Ou seja, frente às críticas à vinculação da arquitetura com 0 desenvolvimentismo, a crença de que o Brasil repetiria o processo histórico dos países avançados e de que a industrialização, extirpando os traços arcaicos na produção, iria possibilitar um futuro social mais justo, Artigas e os demais arquitetos do projeto radicalizaram as propostas de uma arquitetura "industrializada", chegando a elementos que, se em tese estavam presentes no fazer do arquiteto, que deveria projetar do garfo à cidade, na prática ficava restrito ao edifício, até então.

As soluções construtivas foram confrontadas com a dificuldade de se fazer uma planta para a diversidade de tipos de famílias. Mas junto com a diversidade, havia a qualidade. Como se fazer um espaço adequado aos moldes brasileiros? No trecho a seguir, Mendes da Rocha apresentou a explicação desse ponto:

“Em relação aos edifícios em si, o projeto foi pensado de maneira que pudesse dar uma condição de habitabilidade e que fosse ao mesmo tempo razoável em relação aos costumes, ao que é molde do povo brasileiro. Na casa procurou-se integrar da maneira mais natural possível o espaço, de modo que ele pudesse render ao máximo. Como beleza do espaço interno, esses lugares foram também relacionados aos edifícios, assim como as áreas de circulação, as áreas de acesso, as áreas voltada para sala, pudessem estar dentro de uma atmosfera de luz controlada e a face dos quartos com uma insolação aberta para o exterior. Isto dá ao bloco uma dimensão mais razoável" ${ }^{13}$.

${ }^{12}$ Revista Desenho № 04 - Debate CEB 1968.
${ }_{13}$ idem. 


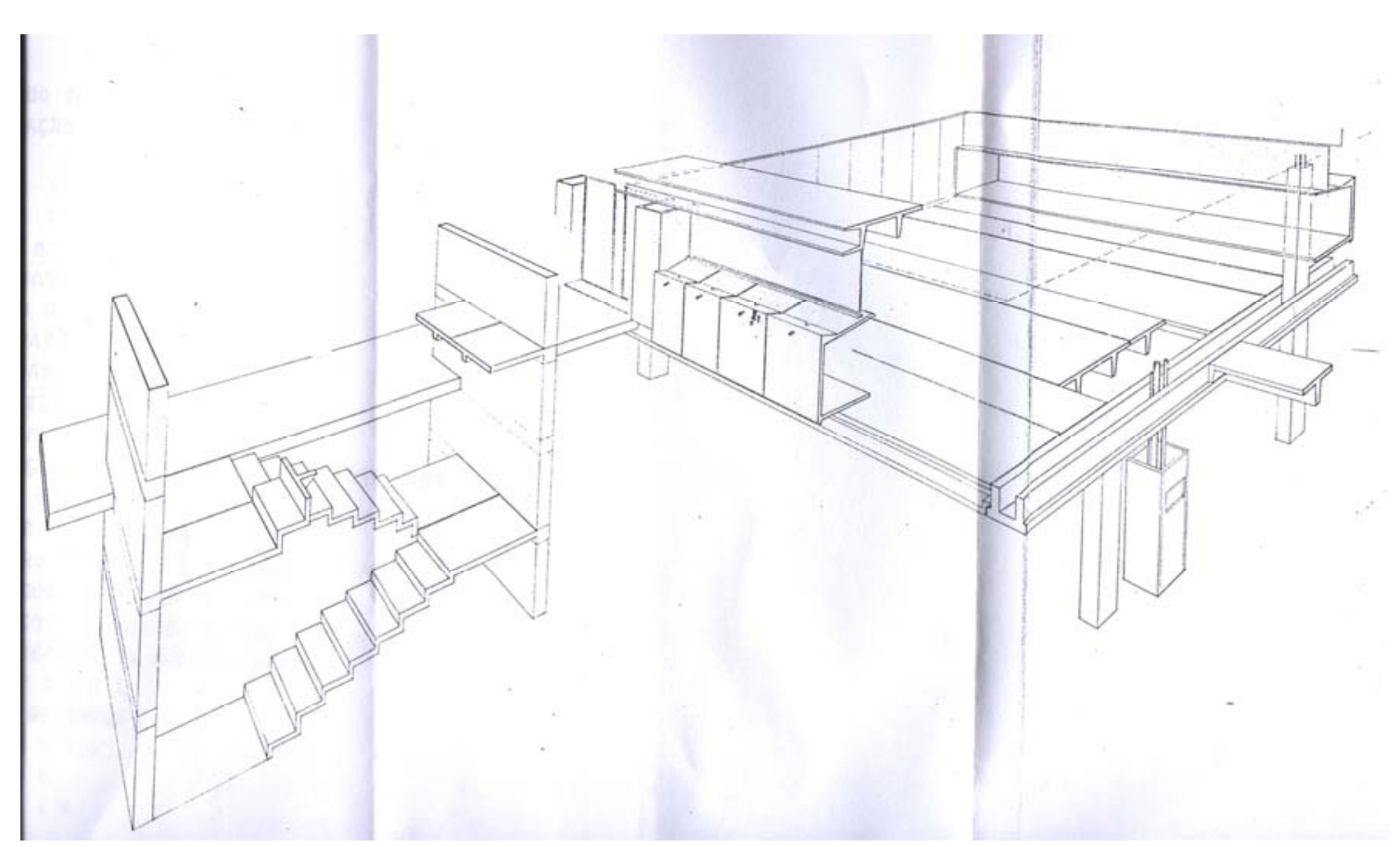

Figura 22 - Vista da montagem pré-moldada do projeto totalmente industrializado. Fonte: Sylvia Ficher.

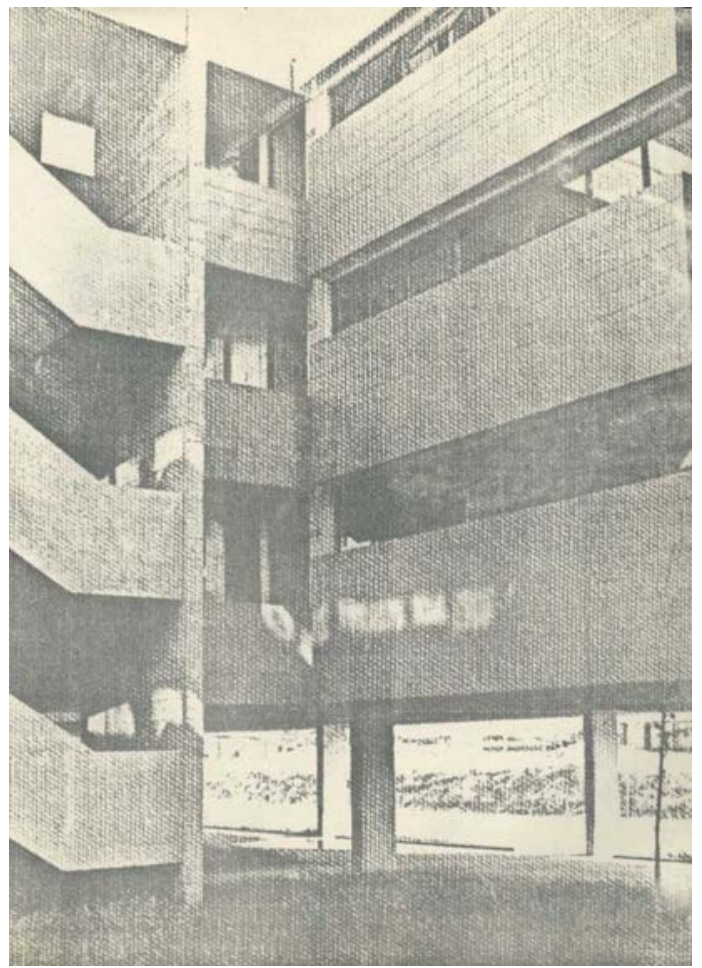

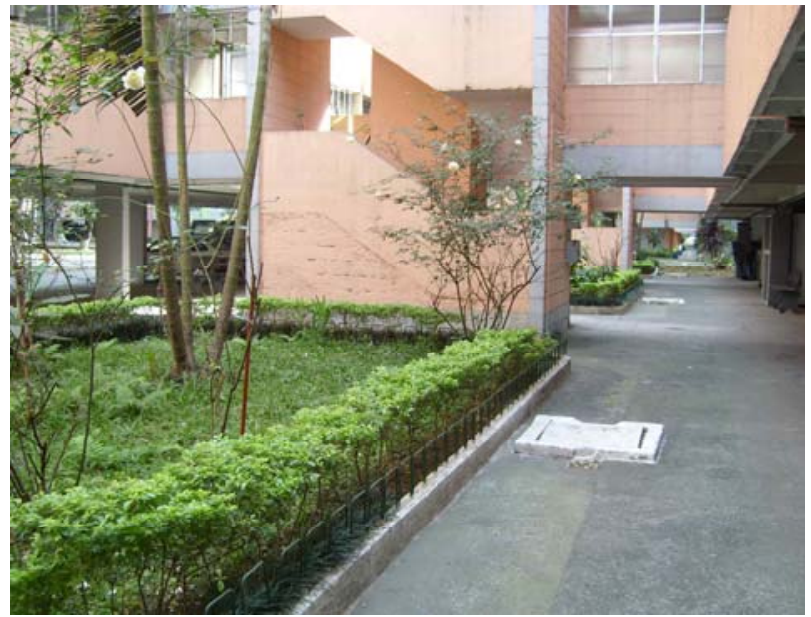

Figura 23 - À cima, o espaço interno entre os edifícios em 2007.

Fonte: Fabiana Cerávolo.

Figura 24 - À esquerda, o espaço interno entre os edifícios em 1972.

Fonte: Revista Desenho 4. 
Nas figuras 23 e 24, é possível observar esse "clima interno" que é todo voltado para as salas, e em visita ao conjunto pôde-se observar e constatar que esta foi uma solução interessante, diante das relações visuais que outras opções de orientação deste cômodo poderiam promover. Na figura 25, podemos observar que os blocos ficaram com uma dimensão razoável que, pela quantidade, produzem uma volumetria agradável ao olhar.

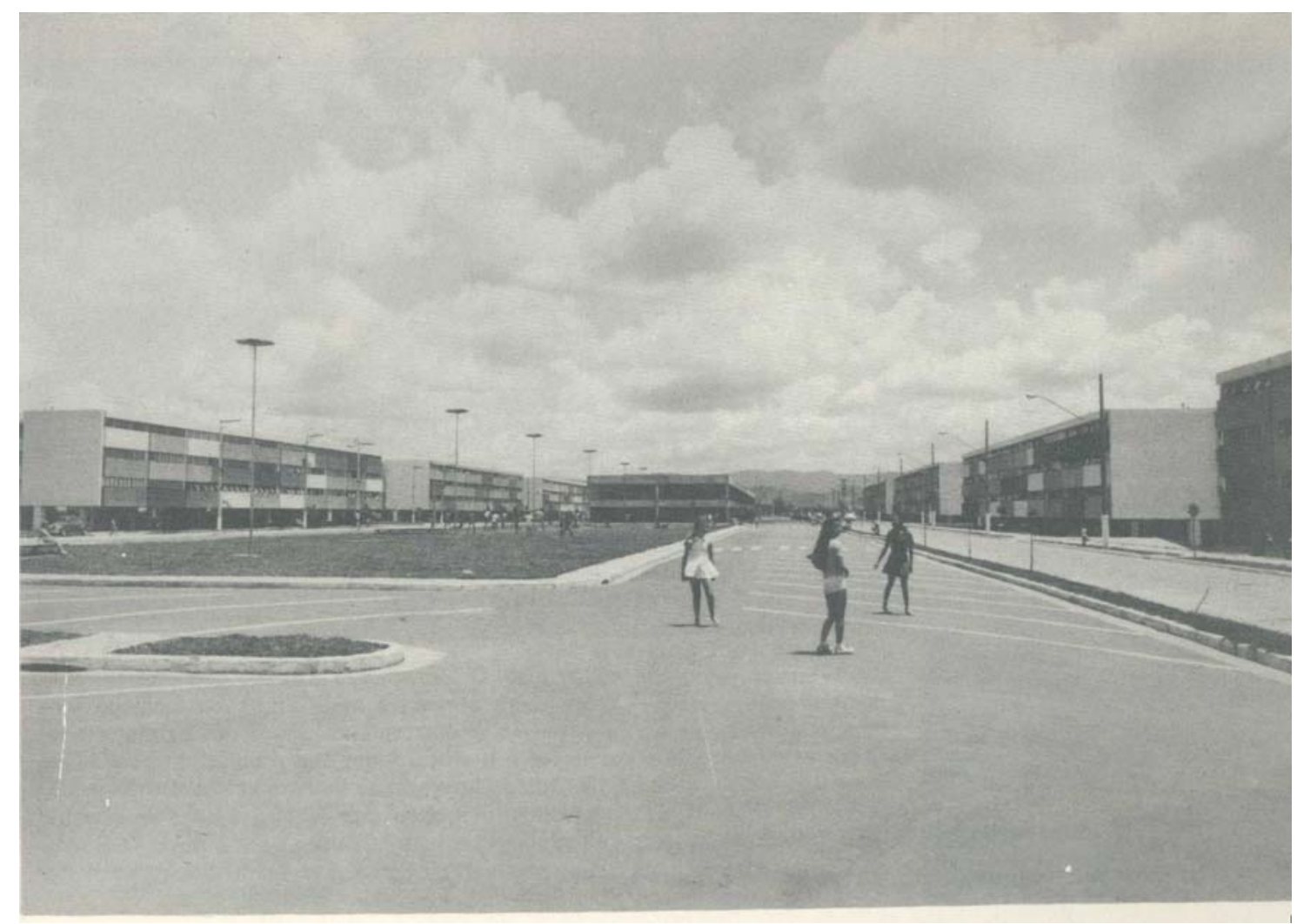

Figura 25 - Lado externo dos edifícios da freguesia F em 1972.

Fonte: Revista Desenho 4.

Os pilotis foram previstos para liberar o solo e estes espaços criados, inicialmente, foram utilizados para atividades eventuais, como a recreação e circulação livre. 0 projeto agregava, assim, um elemento paradigmático do modernismo brasileiro e internacional.

Vilanova Artigas, o arquiteto de visão global sobre o empreendimento, explica o verde no contexto do conjunto: 
“Urbanismo progressista, idéias que foram trazidas para o Brasil da metrópole cultural, no caso quase sempre a França. 0 verde para a solução progressista é um pano de fundo onde se distribuem atividades humanas". ${ }^{14}$

Interessante notar a complementaridade entre a fala de Penteado (anteriormente apresentada) e a de Artigas. A idéia que Penteado expressa é de núcleos compactos, ao que parece, com certa aproximação com os conceitos derivados da noção de "coração da cidade" (cuore), principalmente se pensarmos nas segundas e terceiras gerações de new towns inglesas. Nelas o verde, as áreas livres, deixam de estar entremeadas com o núcleo urbano e as moradias, compondo, como Artigas cita, um grande pano de fundo. Assim, há a informação tipicamente moderna das unidades de vizinhança, mas há também a absorção de discussões mais próximas, que auxiliaram a renovação do pensamento urbanístico na segunda metade do século XX.

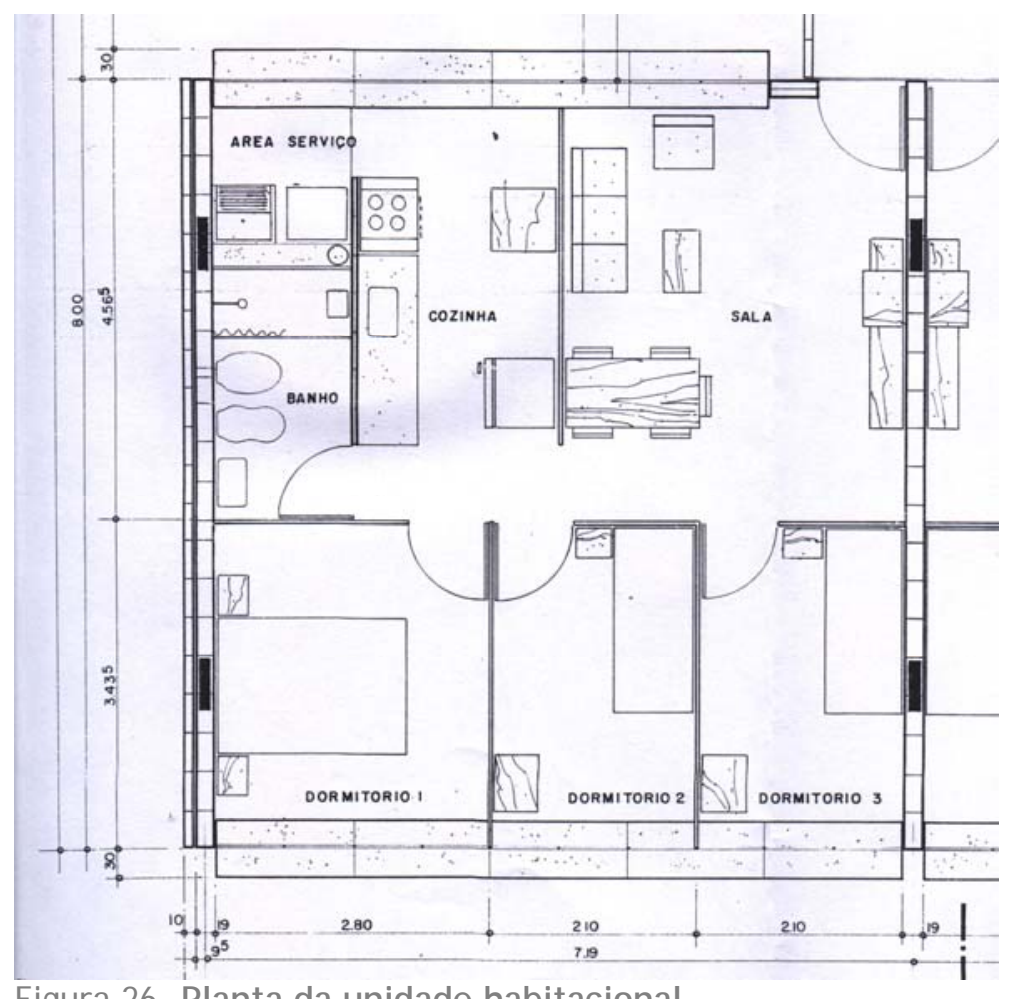

Figura 26- Planta da unidade habitacional.

Fonte: Revista Desenho 4.

\footnotetext{
${ }^{14}$ Idem. Ver BUZZAR (1996).
} 
Novamente é preciso retomar o pano de fundo da discussão sobre as possibilidades do desenvolvimento industrial no país e o papel dos arquitetos nesse processo. As declarações dessas três principais figuras são típicas de um esforço em tornar crível a industrialização da construção no Brasil, mas, sobretudo, tornar o processo de industrialização, um Processo Nacional, porque trás benefícios para o povo; tanto em termos econômicos - moradias mais baratas, permitem uma produção maior, portanto, incidindo positivamente em relação ao déficit habitacional, como em termos de bem estar físico e social - habitabilidade e costumes. A tarefa que se propunham era a de, como arquitetos, auxiliar o país a trilhar o rumo da industrialização, desenvolvendo o seu campo específico de conhecimento, o da construção, fazendo da arquitetura um instrumento indutor da racionalização construtiva, articulando proj eto e obra.

O projeto nacional desenvolvimentista era muito criticado por vários grupos de esquerda, principalmente, após o golpe de 1964. A industrialização não se efetuara como esperado, extirpando o arcaísmo na produção e social, a dita burguesia industrial parecia não estar em desacordo com os rumos do regime militar e os trabalhadores continuavam explorados e sem moradia digna. Renovar os ideais do projeto nacional desenvolvimentista - libertação nacional frente ao imperialismo, binômio democracia e desenvolvimento, por exemplo - exigia um aprofundamento das idéias nacionalistas anteriores. As produtivas como vimos e as ideológicas.

Estas se estendiam na noção de trazer para a conceituação do projeto termos locais, do passado colonial na definição de um território que passava a ser gerido, retirado da natureza. Ainda em declarações de Artigas, ele explica o porquê de usar uma palavra como Freguesia em vez de vizinhança e até o nome de Estados do Brasil colocados nos dos condomínios: 


\section{“(...) a medida que procuramos criar bases para um urbanismo que pudesse ter raízes nossas, arranjar palavras que o caracterizassem com menos aspectos abstratos, com algum conteúdo cultural brasileiro." 15}

Por tudo que foi visto, o debate foi muito mais do que uma "apresentação do projeto" foi um palanque de defesa de uma posição de como fazer arquitetura naquele momento. Por vezes, a compreensão do conjunto das questões que o debate revela, se dá nas suas entrelinhas. Dele participou Cândido Malta, que em determinado momento postulou a flexibilização dos espaços internos das unidades através de painéis móveis. Para Rocha isso soou como uma defesa da participação dos moradores na obra, tendendo à participação, ou delegação do fazer arquitetônico ao trabalhador na obra, ou algo parecido, que integrava as idéias de Ferro e Lefèvre, associada à utilização de técnicas e materiais convencionais. Sendo assim respondeu:

“Eu não posso concordar com você: ficou claro, do que você disse, que esta liberdade possa ser entendida como o carregar paredes, de jeito nenhum, inclusive a própria técnica não é deste nível. As paredes que se encontram nas obras pesam toneladas. Não se trata disto. Não é neste nível individualista que nós temos essa liberdade.

Eu confesso que me comove saber que certas obras refletem essa liberdade, mas eu acho que não está bem interpretado por você. Não é uma liberdade de se confeccionar o seu espaço no sentido - por mais que você tenha feito a ressalva - do decoro. São imutáveis as paredes quando elas pesam mais de 400 quilos. É uma visão de desordem total a que você coloca no arranjo do espaço da família, ainda mais que estamos discutindo um plano que envolve aspectos de uma ligação com uma estrutura muito maior, um grupo social de milhares de pessoas, em que a unidade deveria ser um dado harmonioso em

\footnotetext{
${ }^{15}$ Idem. Ver BUZZAR (1996).
} 
relação ao todo, mas o importante é o resultado obtido com a execução do todo, muito mais do que este detalhe. É uma visão levada ao plano da satisfação individual e de configuração do espaço individual num sentindo muito imediatista. O espaço que nós tratamos é um espaço de consciência universal, é uma liberdade ao nível de um projeto universal e não particular". ${ }^{16}$

Independente da fala de Cândido Malta, as respostas revelam a defesa da arquitetura moderna vinculada aos processos de industrialização e o papel do arquiteto como o articulador da racionalidade produtiva. O ganho social, como informa a Declaração de La Sarraz, viria pela racionalidade (projeto/planejamento). As propostas que não entendiam esta relação, ou que dela divergiam eram imediatistas e particulares, não percebiam o conjunto das questões, o projeto universal e histórico, de progresso social que o desenvolvimento industrial embutia.

\section{Construção do Conjunto Habitacional Zezinho Magalhães Prado}

O Conjunto foi construído basicamente em cinco fases, mas consideraremos três grandes etapas, que são as que guardam diferenças entre algumas características, sendo necessárias licitações diferentes das cinco fases. A cada licitação que foi realizada eram efetuadas inovações e/ ou correções a partir de estudos da fase anterior, corrigindo o que não tivesse êxito. Desta forma os projetos sofreram reformulações contínuas.

Porém, algumas soluções construtivas do conjunto foram mantidas em todas as etapas de obra, como por exemplo: (1) as fundações (figura 29) que são de estacas agrupadas em duas ou três através de um bloco de amarração, sendo que este serve como base para os pilotis, tanto mais esbeltos na primeira etapa, quanto mais robustos da segunda e terceira

\footnotetext{
${ }^{16}$ Revista Desenho no 04 - Debate CEB 1968.
} 
etapa; ${ }^{17}$ (2) as instalações hidráulicas (figura 31) e sanitárias, que são totalmente concentradas nas paredes entre unidades, com uma ramificação para a pia da cozinha; (3) Instalações elétricas e de gás, sendo a previsão da tubulação de gás uma inovação para época, uma vez que naquele período não havia gás encanado na região; (4) Cobertura (figura 32) com laje pré curada com água e coberta com argila expandida para manter a umidade; (5) Divisórias dos apartamentos foram feitas com estrutura de madeira e divisória de material gesso, sendo $1 \mathrm{~cm}$ de gesso de cada lado (ISSAC, PENTEADO ${ }^{18}$, 2007), apenas na fase I se foi tentado a utilização de blocos do tipo Siporex, sem sucesso (SAVIOLI, 2007) ${ }^{19}$; (6) Projeto do canteiro entre blocos (figura 30), sendo que a parte verde dos condomínios foi cuidada pelos próprios moradores, pois unidades foram entregues sem qualquer tipo de vegetação.

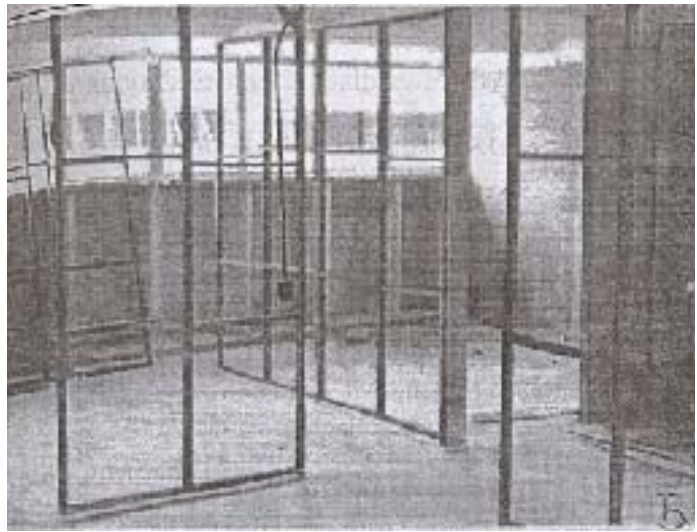

Figura 27 - Montagem das estrutura de madeira que sustentam o gesso.

Fonte: Arquivo CDHU.

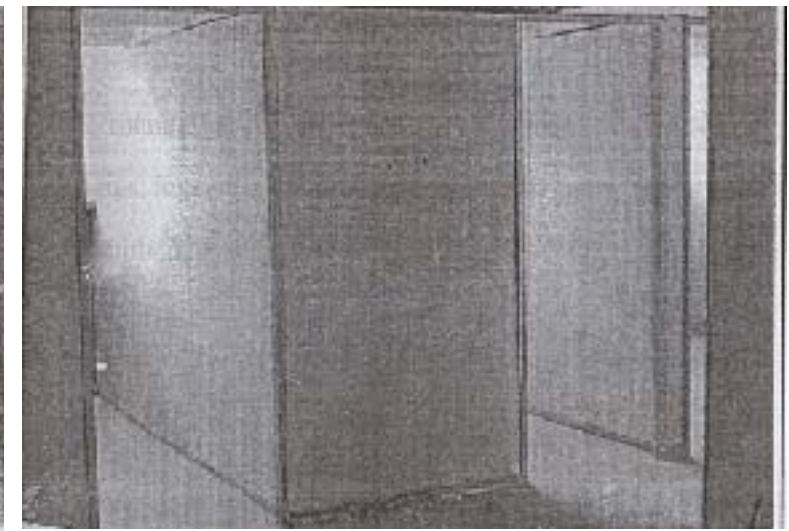

Figura 28 - Divisórias de gesso.

Fonte: Arquivo CDHU.

\footnotetext{
${ }^{17}$ Para Fernando Gonçalves : "havia umas inovações importantes, principalmente estrutural, os prédios sem baldrame, eles tinham uma concepção que as próprias vigas na verdade travavam os três andares". Em entrevista do engenheiro Fernando Gonçalves a autora em 05/ 04/ 2007.

18 Entrevista de Fábio Penteado à autora em 09/03/2007.

${ }^{19}$ Entrevista de Mário Savioli à autora em 05/ 04/ 2007.
} 


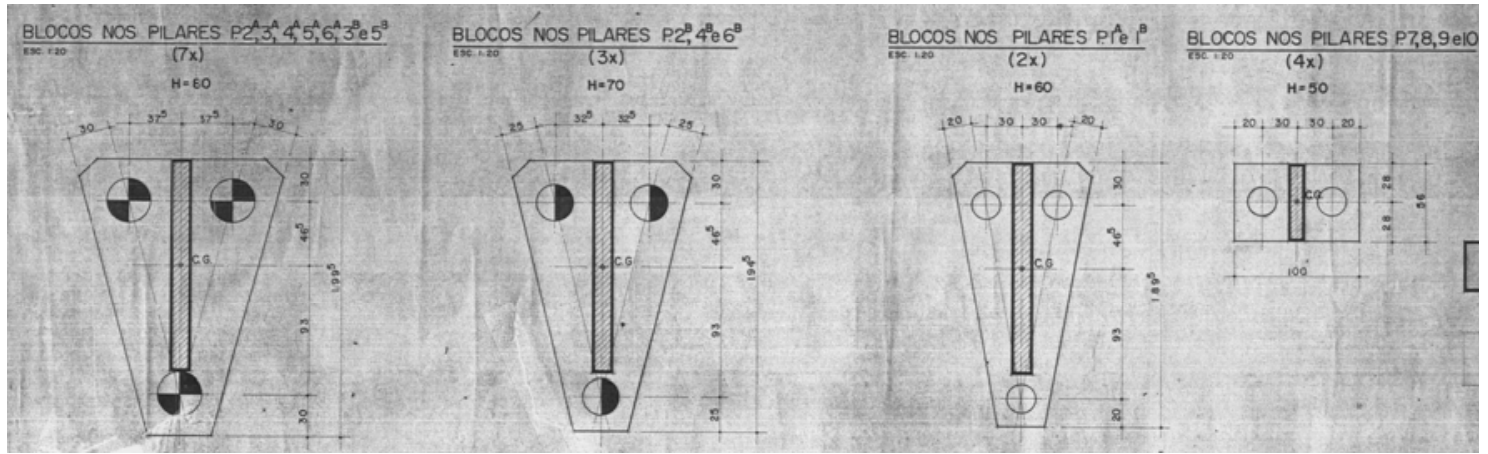

Figura 29 - Fundação do tipo estaca, amarrada com bloco de concreto, base dos pilares. Fonte: Arquivo CDHU.

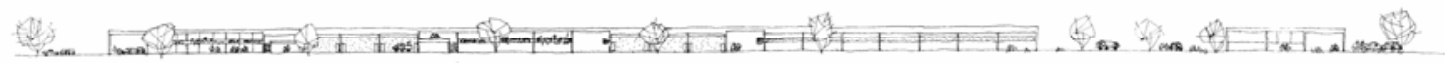
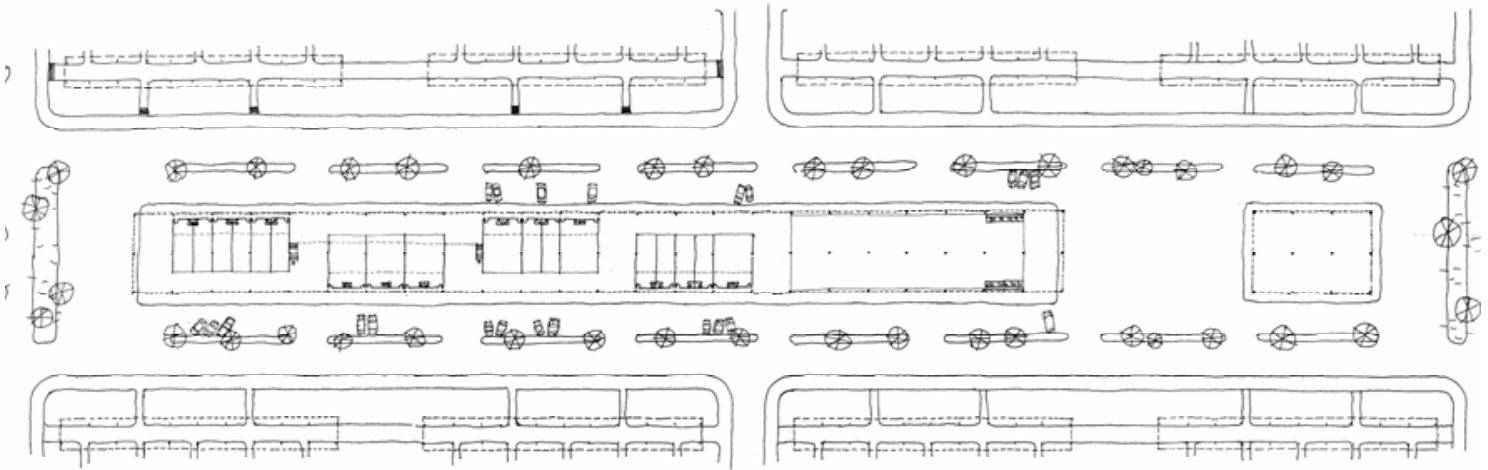

Figura 30 - Canteiro entre blocos.

Fonte: Arquivo FAU-USP (Fundação Artigas). 


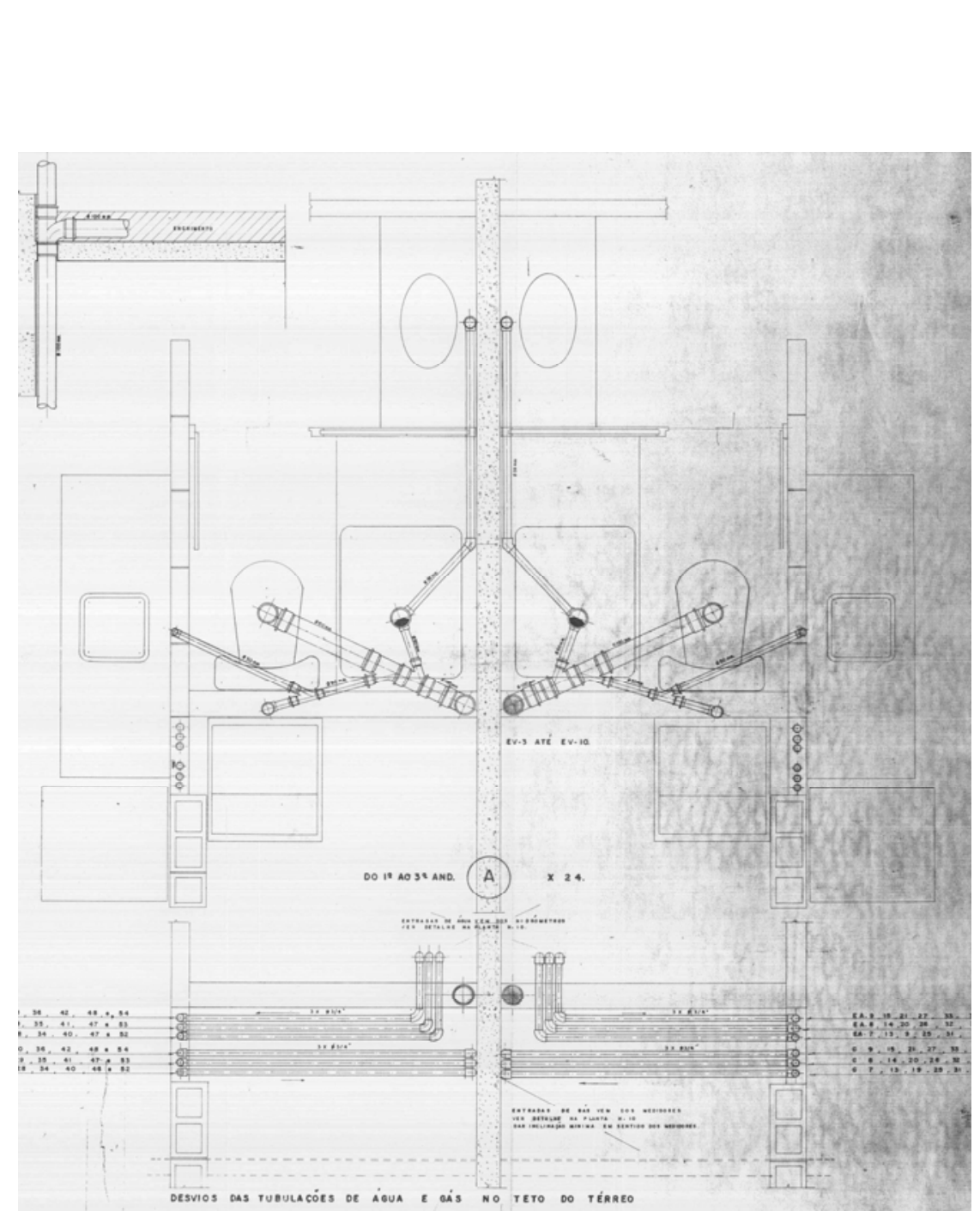

Figura 31 - Detalhe da parede hidráulica entre unidades habitacionais. Fonte: Arquivo CDHU.

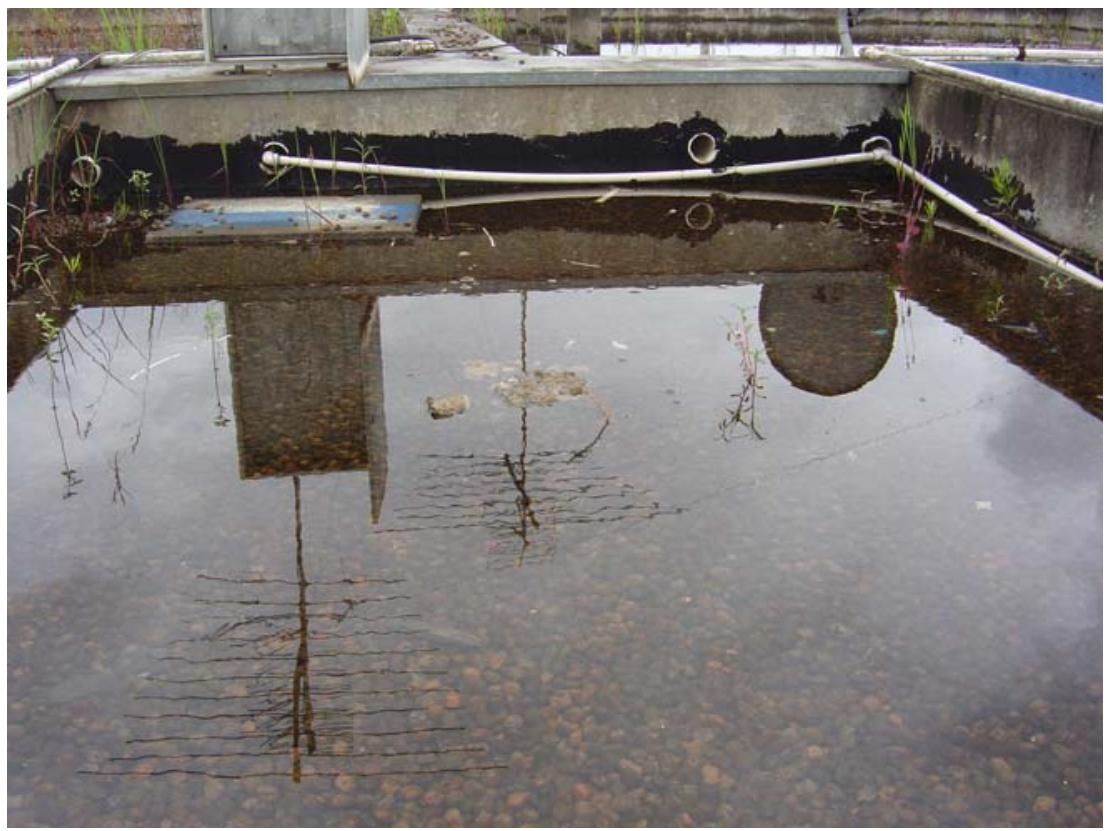

Figura 32 - Cobertura de laje com argila expandida mantida coberta com água. Fonte: Fabiana Cerávolo. 


\section{1a ETAPA}

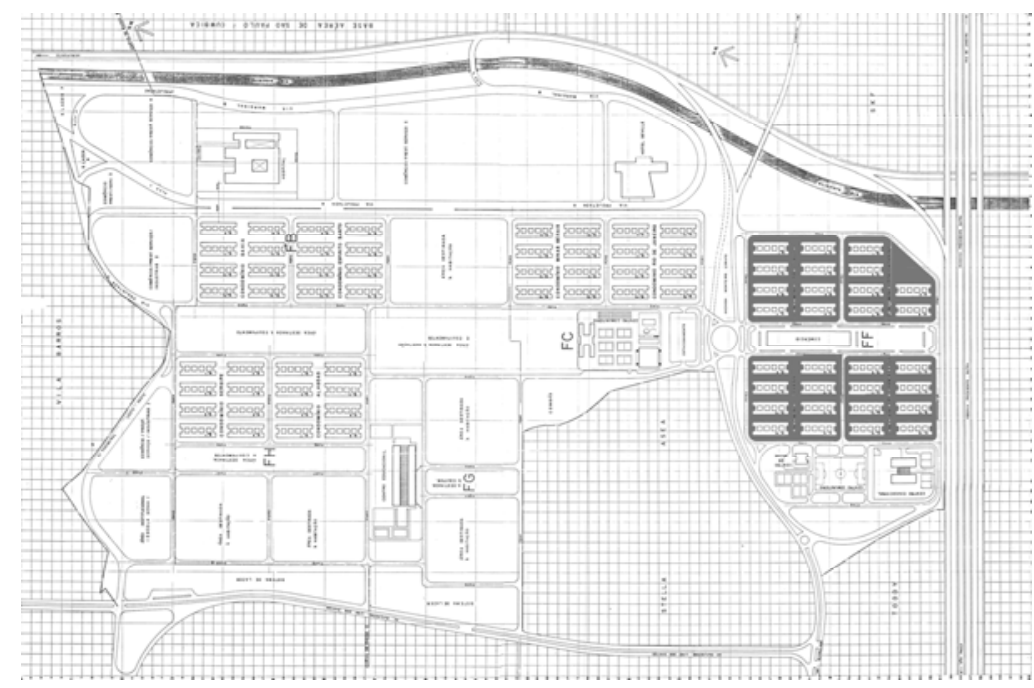

Figura 33 - Localização da $1^{\text {a Etapa. }}$

\section{Resumo da 1a Etapa}

Condomínios

São Paulo, Santa Catarina

Paraná e Rio Grande do Sul

\begin{tabular}{lc}
\hline Blocos & 30 \\
\hline Unidades Habitacionais & 1800 \\
\hline Fase & I e II \\
\hline Período & 1968 a 1972 \\
\hline
\end{tabular}

A primeira etapa foi subdividida em duas fases (I e II) de implantação:

“Em 1970 foi posta em concorrência a construção de 1/4 de freguesia, ou seja, oito edifícios para serem feitos pelos métodos construtivos convencionais. Esses edifícios serão acabados ainda este ano, já está pronto e será publicado na próxima semana edital de concorrência 
para a construção do restante dessa freguesia (24 edifícios e um bloco de comércio da freguesia)" ${ }^{20}$

Para a primeira fase de construção (da primeira etapa), foi apresentado o projeto completo executivo. $\mathrm{O} \mathrm{BNH}$, porém, liberou recursos para serem construídas apenas 480 unidades distribuídas em 8 blocos, o que equivale a 1/4 de uma freguesia. Como relato importante desse processo, em 1972, 0 arquiteto colaborador do projeto Alfredo Paesani, relatou a situação do conjunto no mesmo ano, ao final da 1a fase:

"O setor que nestes dias está sendo ocupado pelos moradores é composto de 480 unidades, o que representa $5 \%$ do total previsto para todo o conjunto. Já foram executados também, o sistema viário de acesso, as redes gerais de água, esgoto, águas pluviais e energia elétrica dos entornos do setor entregue." ${ }^{21}$

Mas o mais significativo presente no relato anterior de Ficher é a afirmação de que os edifícios da primeira fase foram executados segundo métodos construtivos convencionais. Assim, em que pese todas as idéias e a defesa das concepções industrialistas e da utilização da pré-fabricação, a execução divergiu da concepção original e se deu, como na maioria absoluta das obras habitacionais naquele período, sob a égide da utilização de mão de obra barata da forma mais extensiva, que inibia e contra-estimulava a disseminação da pré-fabricação. Sobre esta questão o depoimento de Penteado é significativo, tanto das expectativas, como do ocorrido. Segundo o arquiteto, o projeto:

\footnotetext{
${ }^{20}$ FICHER, S. (1972); Subsídios para um Estudo do Conjunto Habitacional Zezinho Magalhães Prado. Monografia de conclusão de curso (TCC). FAU-USP.

${ }^{21}$ Revista Desenho no 04 - Debate CEB 1968.
} 
“(...) foi pensado pré-moldado inteiro, mas também por uma fantasia ou poesia, foi feito o projeto, calculado todo para pré-moldado, custou uma fortuna o contrato do projeto de estrutura pré-moldada. É mesma coisa, primeiro, não fazia parte e ainda hoje não faz parte da cultura, na época que a gente construiu. Segundo, se você faz uma usina e faz aquela obra CECAP, aí joga fora a usina, porque não teria outra pra fazer, o custo disso era tão grande que não foi, a única coisa prémoldada lá foram feitas as escadas e alguns componentes. Que hoje você encontra em qualquer parte do Brasil, São Carlos, Campinas, todo interior do Brasil, o cara já faz uma escada de um prédio pré-moldada, já existe uma facilidade de mão-de-obra em tudo quanto é lugar, é só isso. Foi feito o projeto mas não foi usado!"22

Explicitando, Penteado citou detalhes da construção executados pelo método tradicional ou convencional:

"Blocos de concreto. E as divisórias em gesso. O piso, por exemplo, foi estudado. Tinha uma empresa no Rio de J aneiro, claro que havia pisos de rolo, tipo Paviflex, permitia que você colocasse sobre o concreto 0 material, mas é de baixa durabilidade." 23

Ainda sobre a questão, mas também discutindo a contribuição maior do projeto, no caso, o incentivo imaginado à indústria da construção, Penteado completou:

“(...) A tentativa de transformar, quando você me perguntou, qual era o interesse de fazer, a contribuição que esse projeto poderia dar em tudo, na indústria da construção, por exemplo, eu

\footnotetext{
${ }^{22}$ Entrevista de Fábio Penteado à autora em 09/03/2007.

${ }^{23}$ Idem. Aqui há uma pequena contradição. Questionada sobre as divisórias a arqta. Maria Giselda Cardoso Visconti afirmou: "Na primeira etapa foram utilizadas divisórias de fórmica e nas outras placas de gesso", Entrevista de Maria Giselda Cardoso Visconti a autora em 09/ 04/ 2007.
} 
pessoalmente mantenho uma idéia, enquanto $1 \mathrm{~m}^{2}$ de construção pesar uma tonelada, a tendência obrigatória de redistribuir peso, reduz a carga de desgaste do meio ambiente. Mas ela acabou como uma obra convencional, (...)" 24

Sobre o processo gerenciamento de obra, que complementa a questão do planejamento, Penteado informou:

“(...)uma grande empreiteira assumiu, (...). E, eu convidei o Falcão Bauer e o Alfredo Paesani, que era meu sócio, no meu pequeno escritório, pra garantir que o gerenciamento da obra ia ser descente, porque a tendência no Brasil é tudo ir pro buraco, então com todo cuidado que você possa fazer, o difícil é que seja correto." 25

Para Maria Giselda Cardoso Visconti:

"A qualidade da obra e o cumprimento dos prazos determinados, resultou, em grande parte, foi programação da obra." 26

Pela entrevista realizada com Fábio Penteado, e pelo exposto pelo arquiteto Alfredo Paesani, parece que os encaminhamentos de planejamento foram preservados (programação), no acompanhamento da obra propriamente dito, na instalação da infra-estrutura do Conjunto, possibilitando um ganho na escala da execução. Dessa forma, a partir do conjunto das entrevistas, podese deduzir que teria havido racionalidade na execução da obra, aproximandoa da definição de Ricardo Martucci de obra executada através de método

\footnotetext{
${ }^{24}$ Idem. Como veremos, segundo a arquiteta. Visconti na terceira etapa houve uma maior utilização de elementos pré-fabricados.

25 Idem.

${ }^{26}$ Entrevista de Maria Giselda Cardoso Visconti a autora em 09/04/2007.
} 
tradicional, mas racionalizado, isso particularmente em relação as duas primeiras etapas.

O engenheiro Fernando Gonçalves que trabalhou na obra de 1971 a 1977 explicou em entrevista o processo rígido de controle de qualidade da obra, incorporado ao processo de execução:

“Foi extremamente controlado. O mecanismo funcionava assim, 0 Bauer fazia todo material que entrava na obra passar por ensaio, então era aprovado pelo Falcão Bauer, a qualidade do material. O Bauer mantinha na obra o Fausto Marioni, era um tecnólogo que acompanhava toda a execução, com uma marreta na mão, quando uma parede estava mal executada ele já chegava e derrubava, ele era odiado na obra pelos mestres. $E$ a gente tinha um grupo de profissionais que acompanhava o trabalho que era executado pelo Bauer, porque ao acompanhar, esse pessoal era treinado para os 132 conjuntos que estavam espalhados, que era uma escola de formação para os outros conj untos." 27

Infelizmente não foi possível obter junto à empresa responsável por toda a obra, a Construtora Rossi, registros confiáveis do processo de obra, mas novamente pela entrevista com Penteado pode-se vislumbrar os objetivos do empreendimento, que tinham a simpatia da empresa:

“A primeira ... (construtora) ..., hoje é a ROSSI, o J oão Rossi, na época era ENGEVICS. Eu comentava com ele, e a gente tava na reunião de um projeto... tive no escritório dele, e lembrei que ele ganhou a concorrência. Houve grande intenção de marcar essa obra como um... não era pra ser bonitinha, seria uma linha de direcionamento para o

\footnotetext{
${ }^{27}$ Entrevista do engenheiro Fernando Gonçalves a autora em 05/ 04/ 2007.
} 
pensamento arquitetônico e de técnicas de construção pra sair da Idade Média aqui no Brasil, mas é muito difícil e muito relativo porque quando se entra na escala dos problemas e de necessidades, são problemas terríveis $(\ldots)^{\prime \prime} 28$

A conformação do bloco (figura 34 e 35) é idêntica em todas as fases, porém o que diferencia é o lance de escadas. Nessa etapa o lance de escadas é no formato de "U", e foi construído pelo método tradicional.

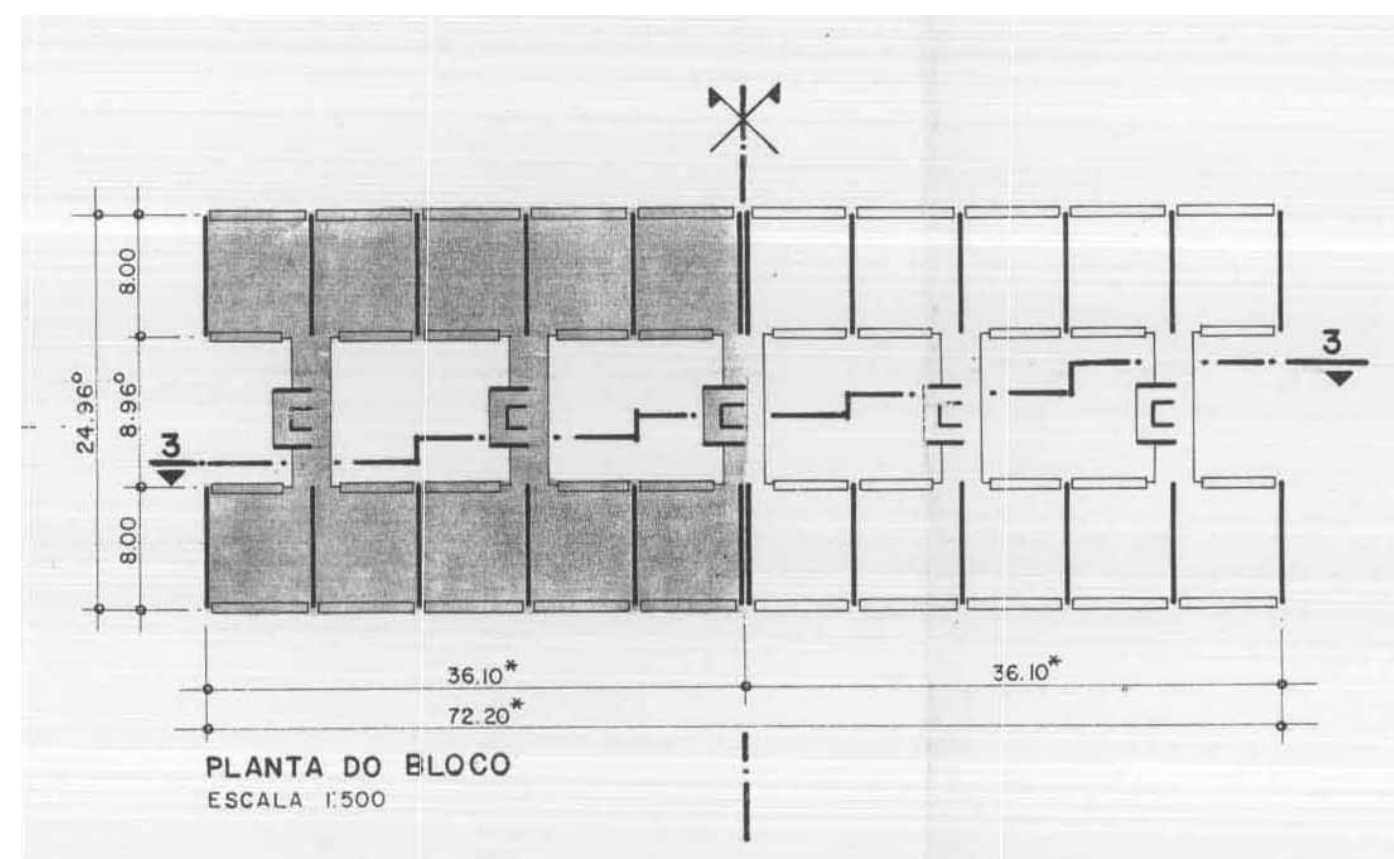

Figura 34 - Vista do bloco com escada em U.

Fonte: Arquivo $\mathrm{CDHU}$.

${ }^{28}$ Entrevista de Fábio Penteado à autora em 09/ 03/ 2007. 


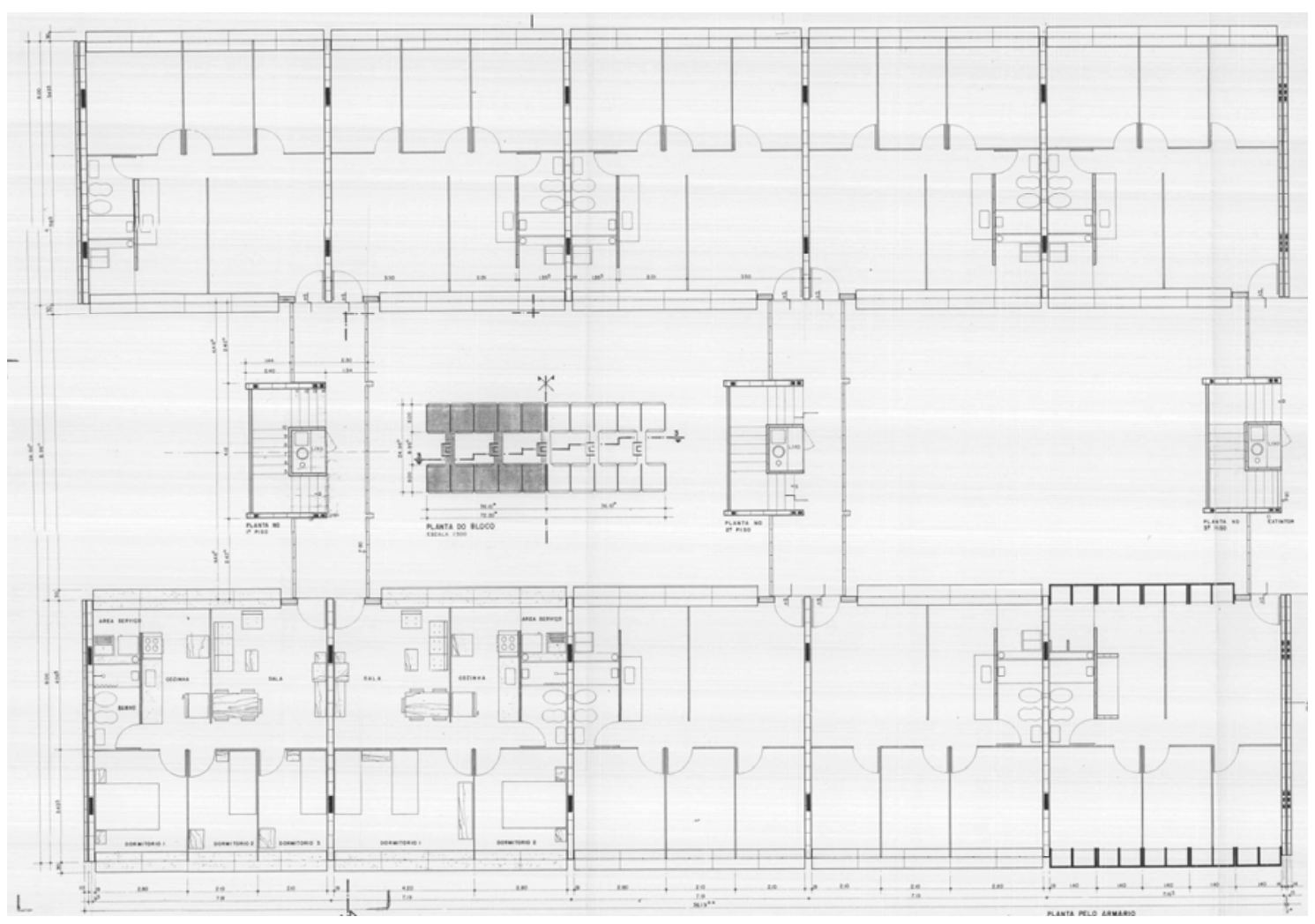

Figura 35 - Detalhe do pavimento tipo do bloco com escada em U.

Fonte: Arquivo CDHU.

Na figura 36, é mostrado o detalhe do lance de escada, com paredes laterais de blocos de concreto de $19 \mathrm{~cm}$ e as restantes de concreto aparente de $9 \mathrm{~cm}$. Reafirmando, essa etapa foi feita toda com método tradicional de construção, com paredes de blocos de concreto (figura 42).

É nesta etapa também que as vigas de concreto (figura 39 a 40) ficaram aparentes, observando nitidamente o formato das mesas e da montagem das vigas, feitas "in loco". 


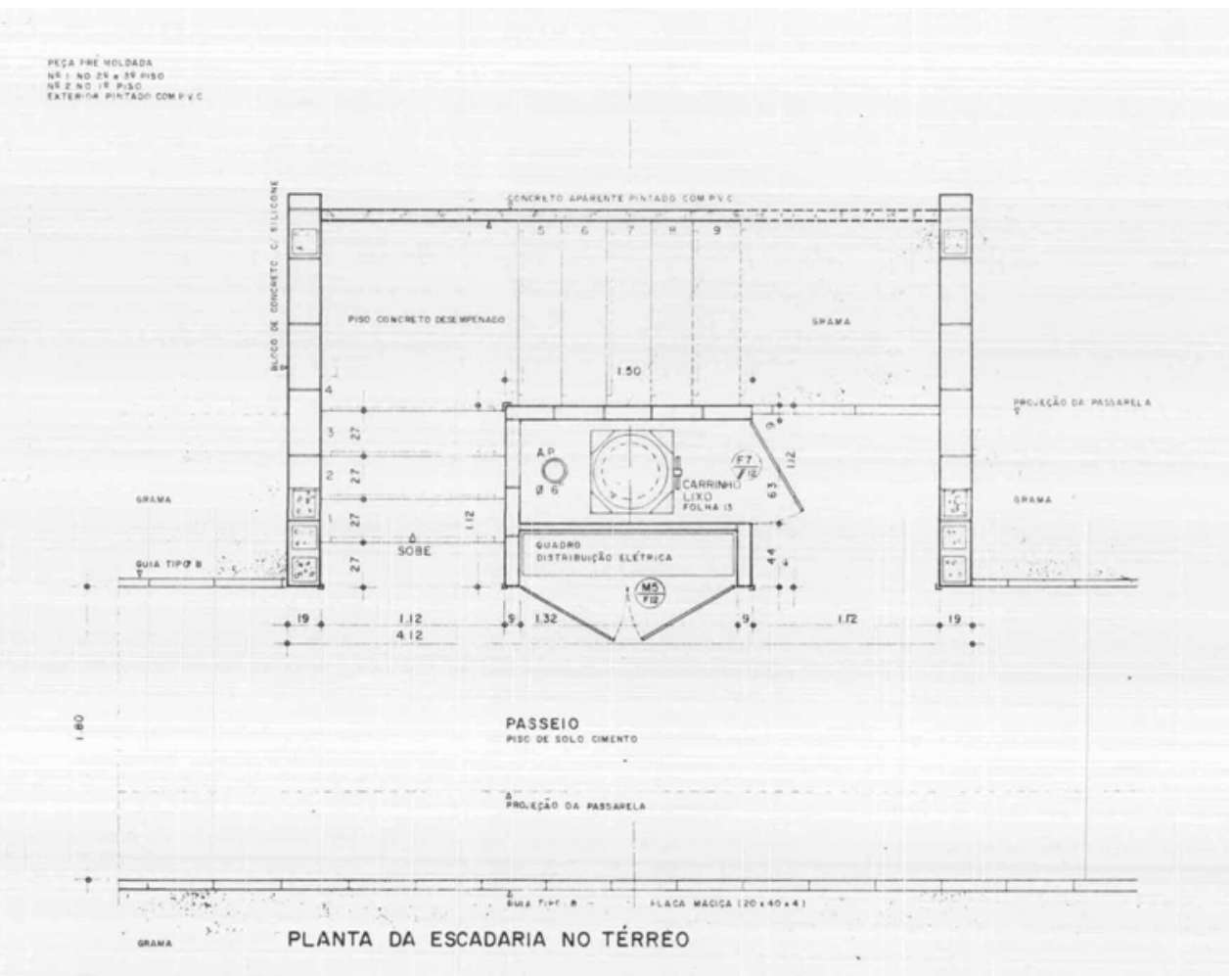

Figura 36 - Detalhe do escada em U, com duto de lixo e quadro de distribuição elétrica. Fonte: Arquivo $\mathrm{CDHU}$.
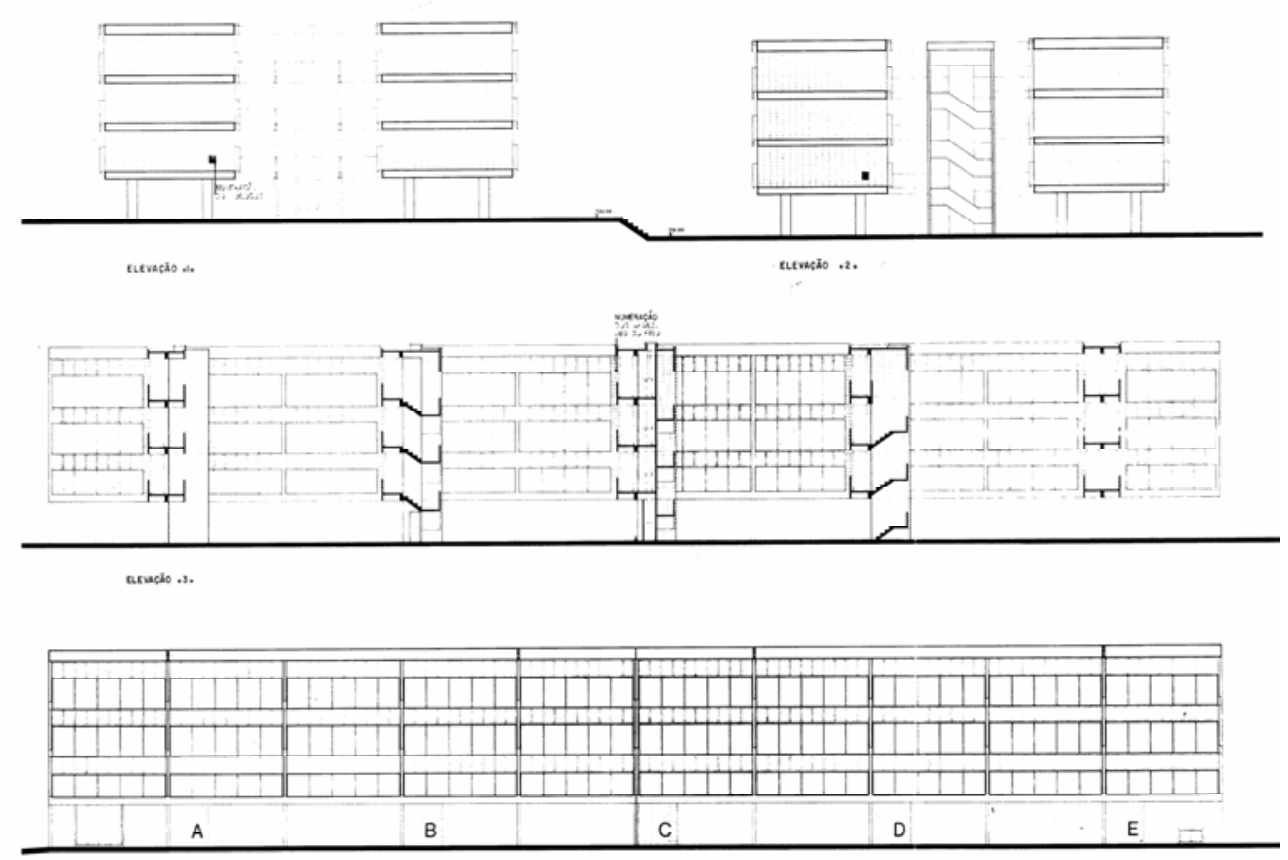

Figura 37 - Fachada lateral, Corte longitudinal e fachada frontal do bloco. Fonte: Arquivo FAU-USP (Fundação Artigas). 

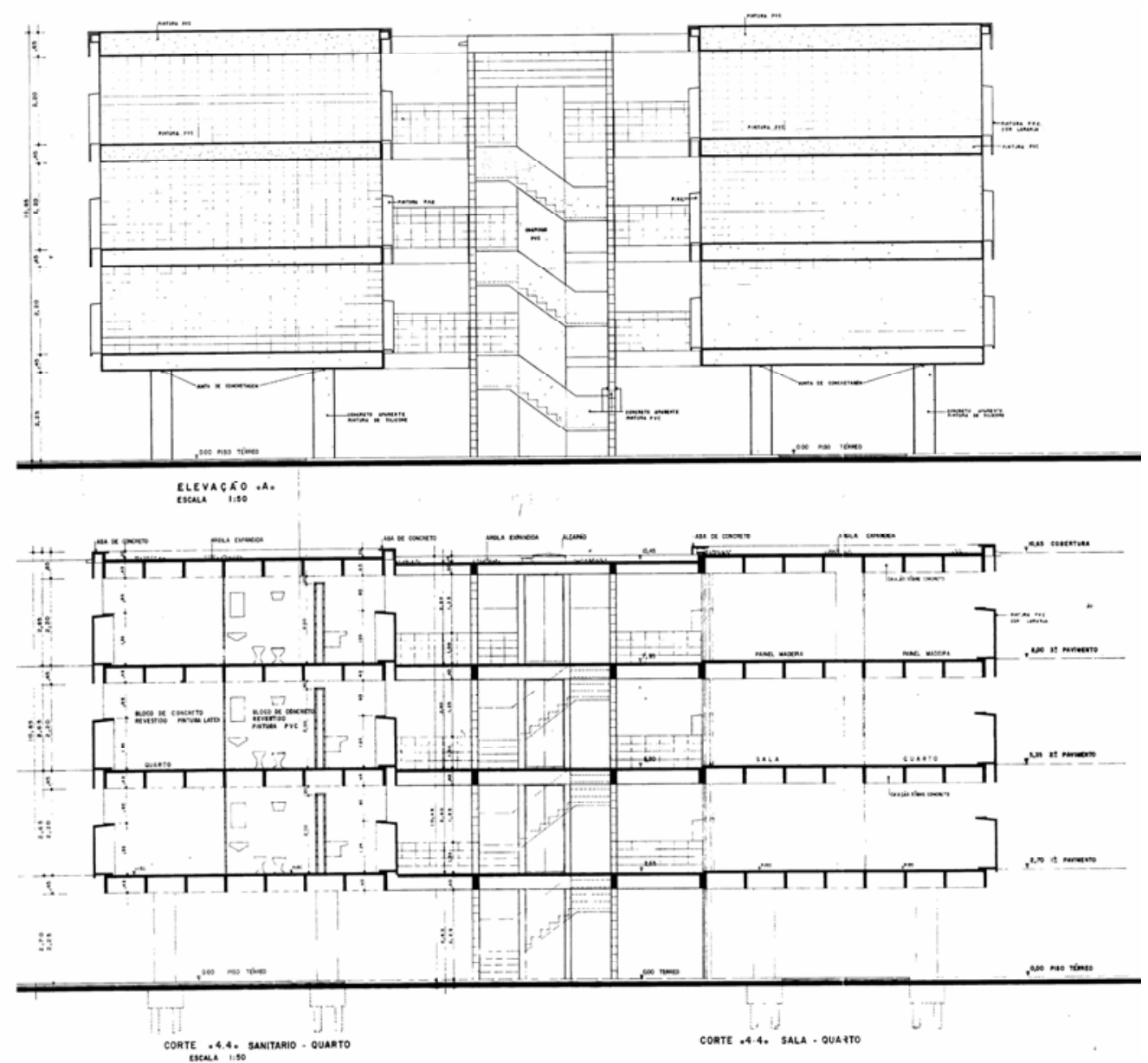

Figura 38 - Fachada lateral e Corte transversal.

Fonte: Arquivo FAU-USP (Fundação Artigas).

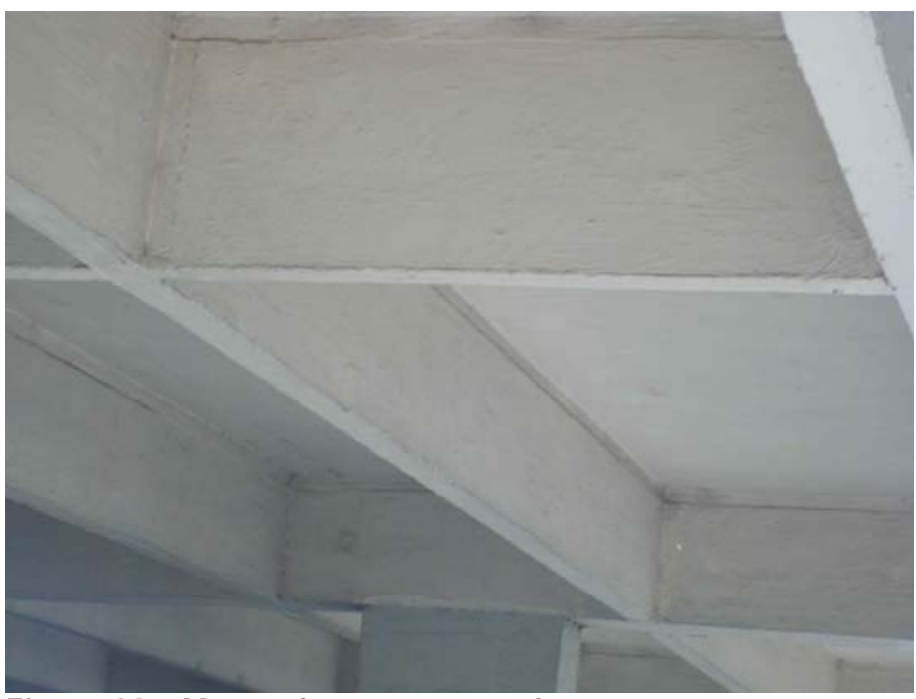

Figura 39 - Mesas de concreto - vigas. .

Fonte: Fabiana Cerávolo.

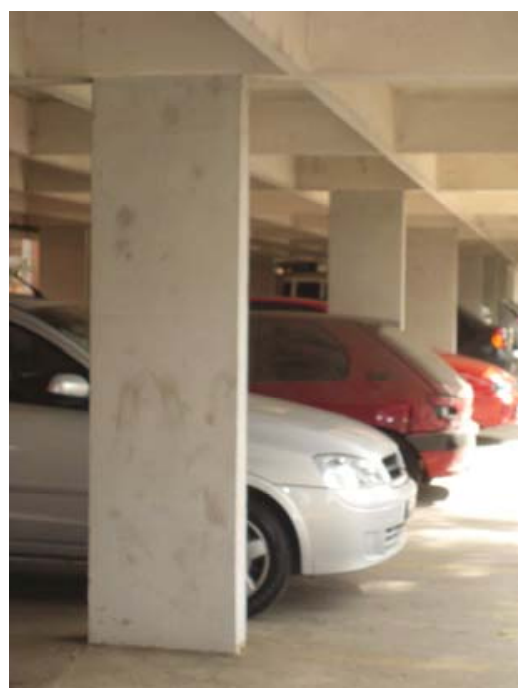

Figura 40 - Mesas -garagem.

Fonte: Fabiana Cerávolo. 


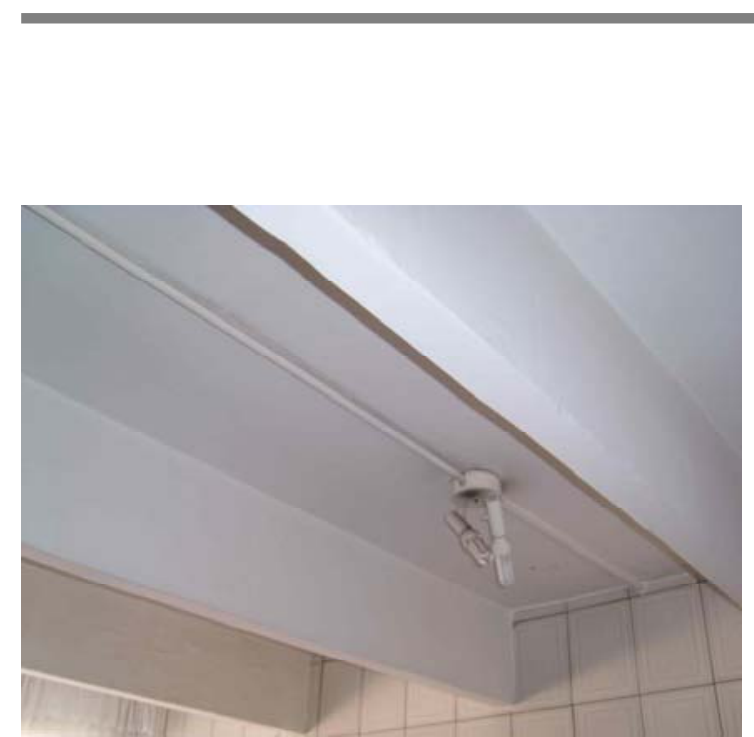

Figura 41 - Mesas de concreto cozinhavigas.

Fonte: Fabiana Cerávolo.

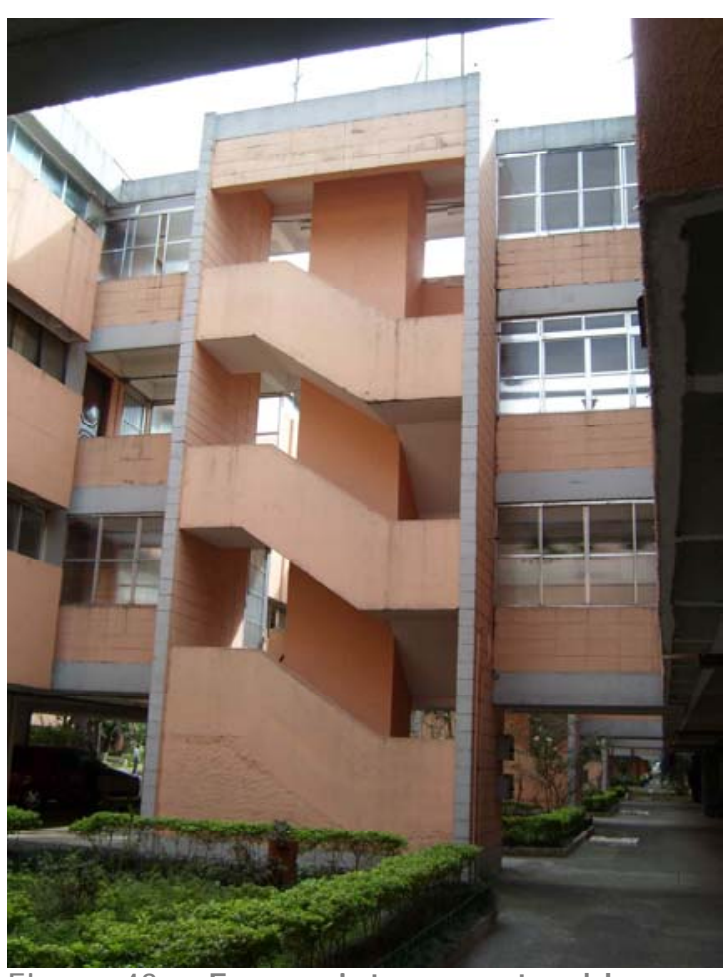

Figura 43 - Espaço interno entre blocos c/ caixa de escadas.

Fonte: Fabiana Cerávolo.

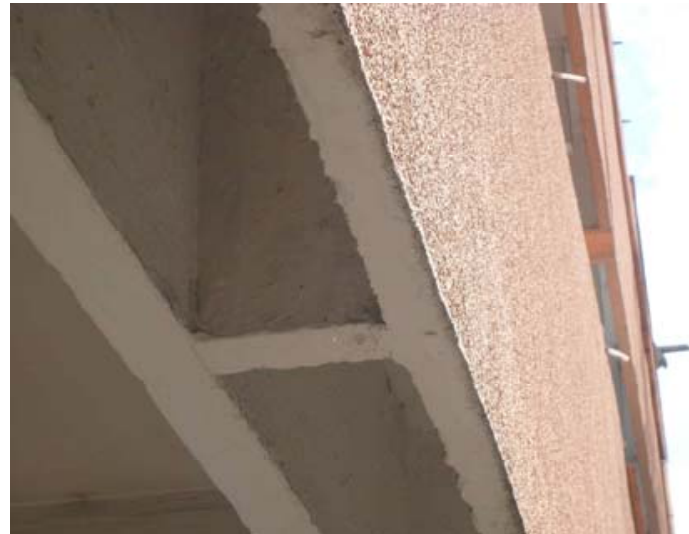

Figura 42 - blocos de concreto - fachada. Fonte: Fabiana Cerávolo.

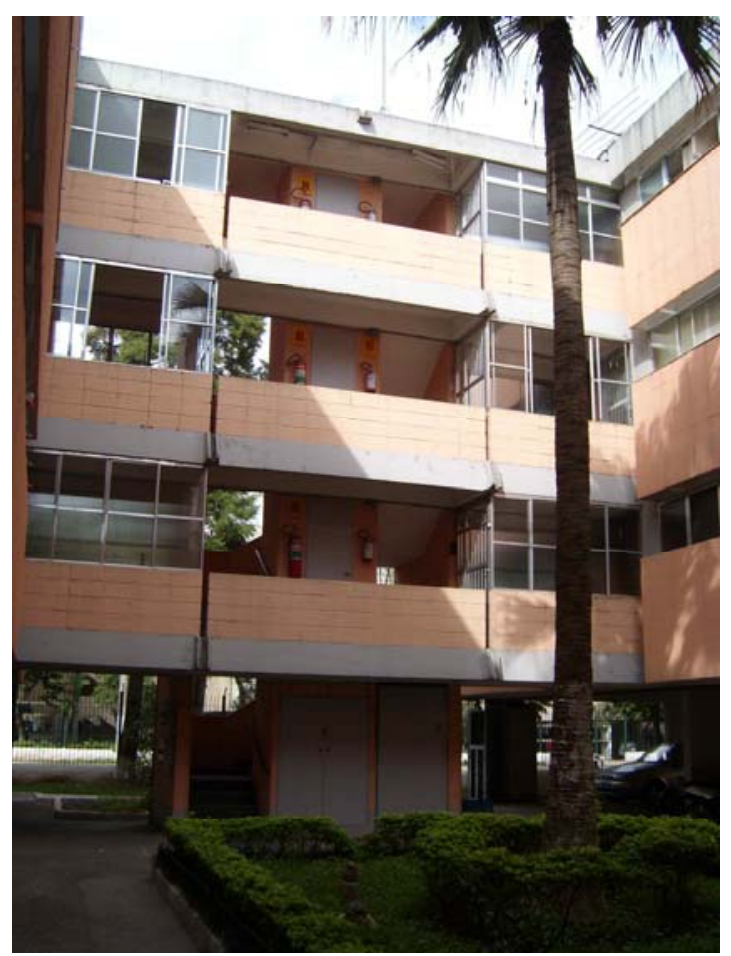

Figura 44 - Espaço interno entre blocos c/ caixa de escadas, vista complementar. Fonte: Fabiana Cerávolo. 


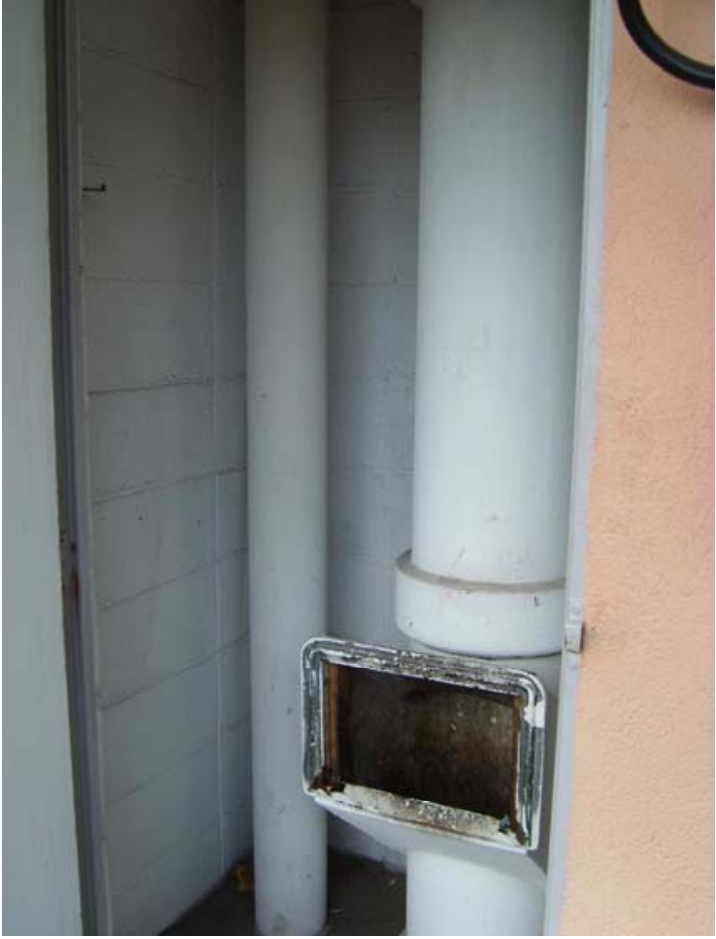

Figura 45 - Duto de lixo e duto elétrico. Fonte: Fabiana Cerávolo.

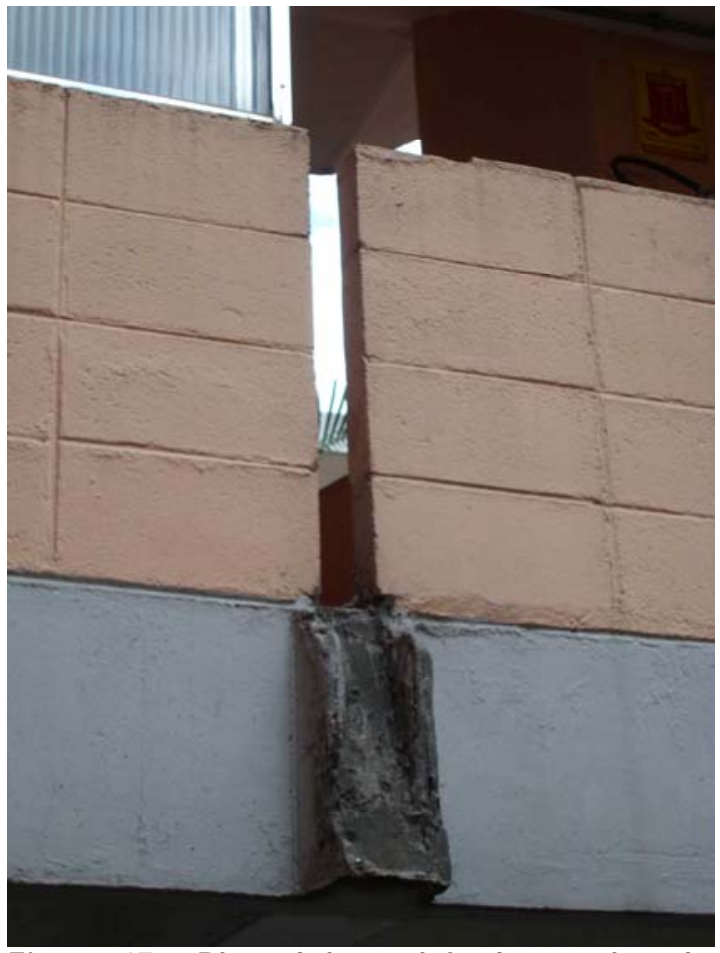

Figura 47 - Pingadeira original na caixa de escada..

Fonte: Fabiana Cerávolo.

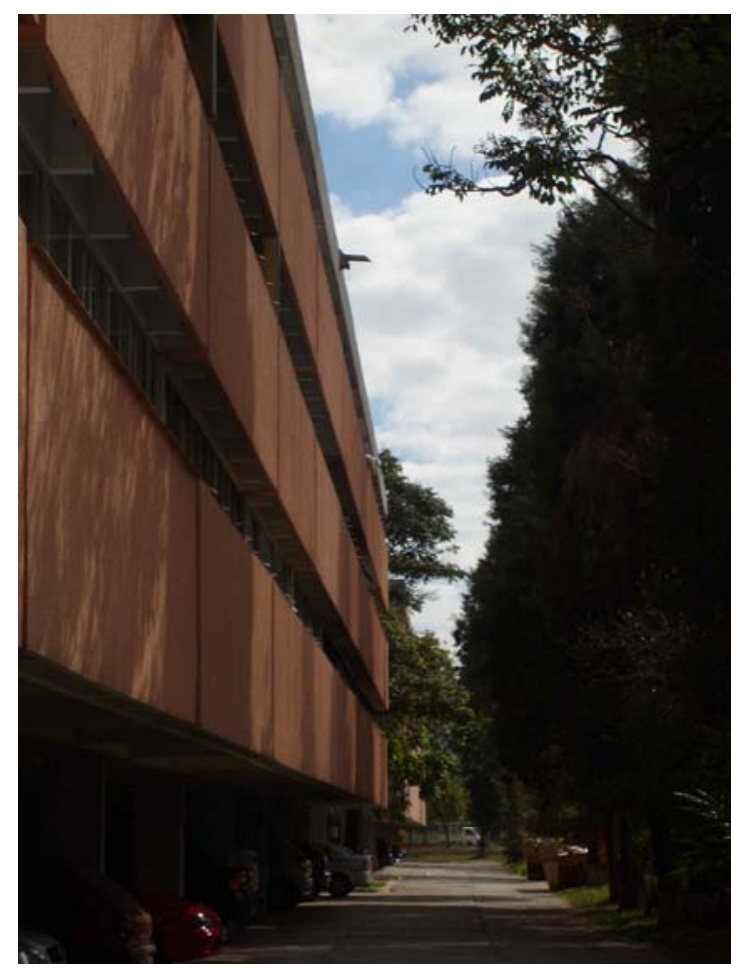

Figura 46 - Fachada - fundos.

Fonte: Fabiana Cerávolo.

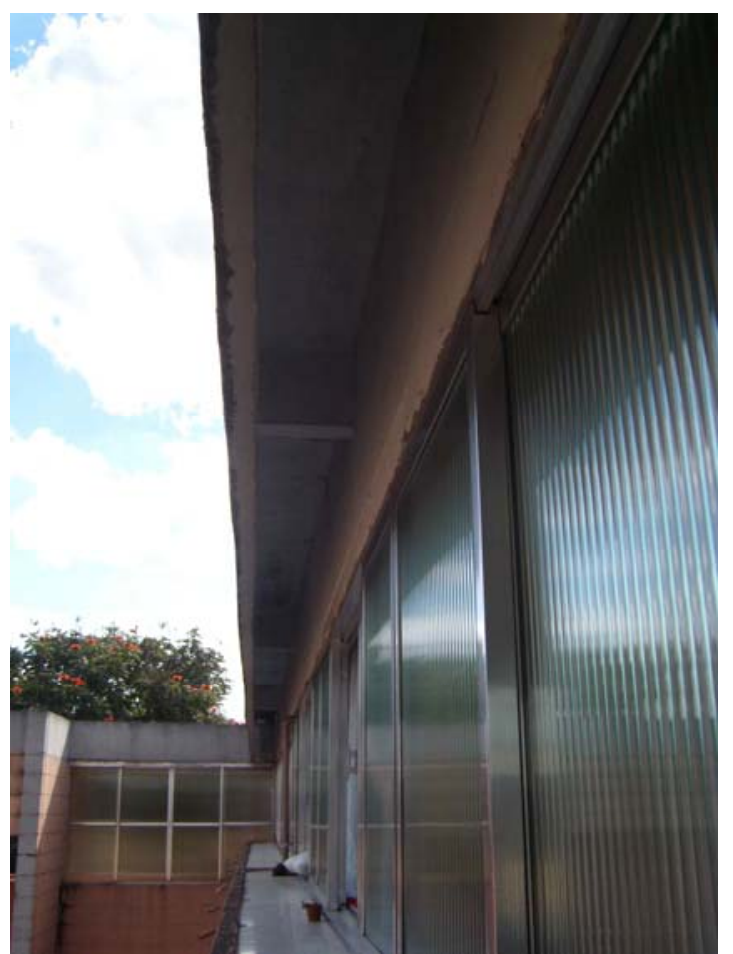

Figura 48 - Pingadeira vazada e caixilhos modificados.

Fonte: Fabiana Cerávolo. 


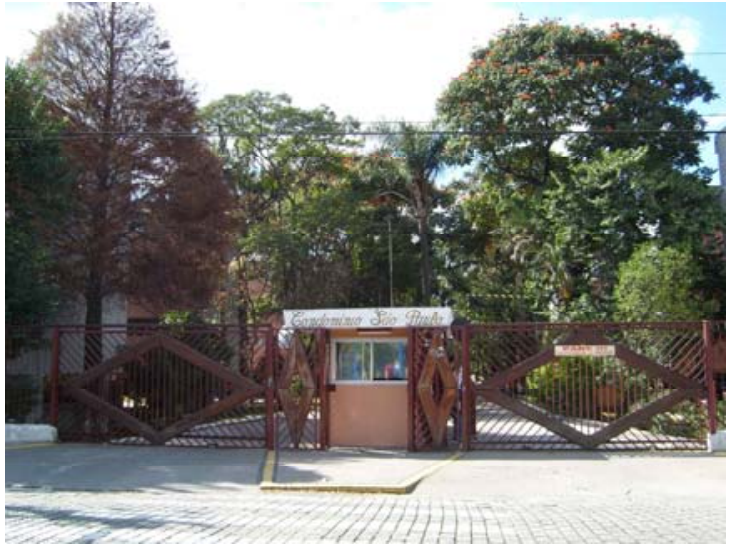

Figura 49 - Portaria Condomínio São Paulo. Fonte: Fabiana Cerávolo.

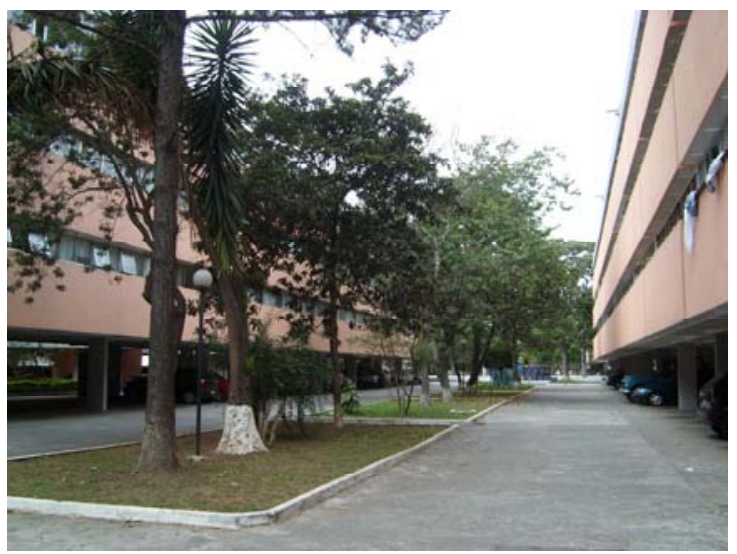

Figura 51 - Canteiro entre blocos. Fonte: Fabiana Cerávolo.

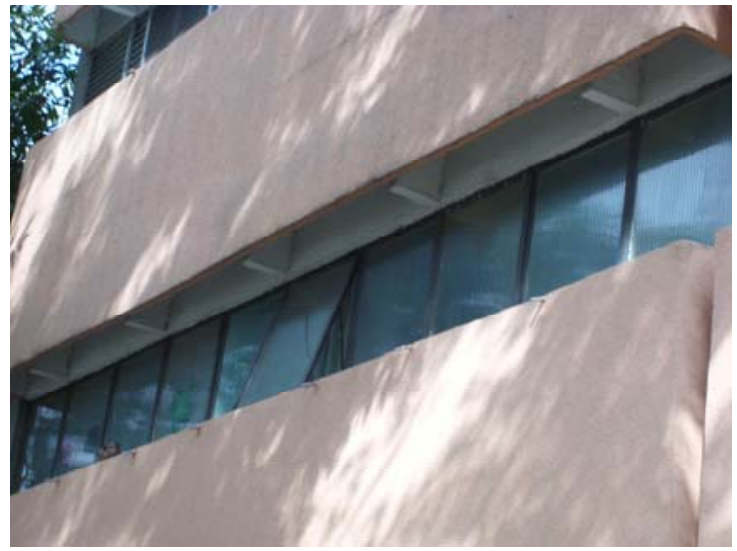

Figura 50 - Caixilhos originais, máx-ar.

Fonte: Fabiana Cerávolo.

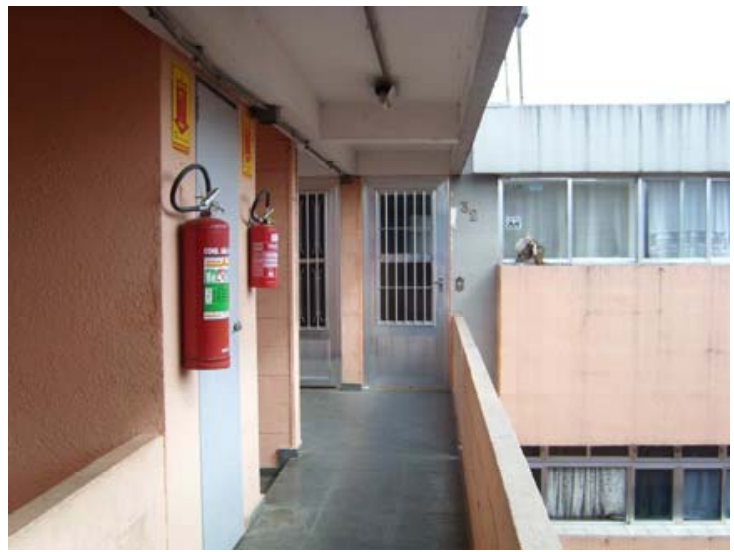

Figura 52 - Hall do $3^{\circ}$ Andar.

Fonte: Fabiana Cerávolo.

Os 30 blocos da primeira etapa são organizados no Conjunto da seguinte maniera: Fase 1, Condomínio São Paulo (8 blocos, 480 unidades); Fase 2 Condomínio Santa Catarina (6 blocos, 360 unidades habitacionais), Condomínio Paraná (8 blocos, 480 unidades habitacionais) e Condomínio Rio Grande do Sul (8 blocos, 480 unidades habitacionais). Esses blocos da primeira etapa (fases 1 e 2) constituem a freguesia FF, a única que foi construída na sua totalidade. 


\section{Projetos de Equipamentos não Executados}

Esses projetos não estão ligados à uma etapa, mas fazem parte da proposta inicial, conforme apresentado no Debate realizado na FAUUSP. Como foram descartados na fase inicial da obra resolvemos discuti-los nesse trecho do trabalho. A sua formulação articula os conceitos da proposta e conveniências, como será visto, e o resultado negativo revela as dificuldades que se apresentaram.

Os equipamentos (figura 53 a figura 58) foram propostos para diminuição do custo final da obra. Destes projetos foram feitos dois protótipos, um do fogão, realizado a pedido de Fábio Penteado à sua família, dona de uma fábrica de fogões, hoje a Dako. E o outro foi o protótipo da geladeira, que foi feito em uma indústria em São Carlos, a Clímax. Nenhum desses protótipos foi construído. Os motivos são vários, mas, sobretudo, combinam a relação que as pessoas estabelecem com o mercado de utensílios em geral e a equação econômica industrial. Os equipamentos para serem fabricados na escala industrial, deveriam ser destinados para outros conjuntos ou para o mercado em geral. Sem esta perspectiva permaneceram como protótipos. Há outras considerações, mas consideramos complementares. Sobre a questão de viabilizar equipamentos e, também, 0 mobiliário no Conj unto Penteado afirmou:

“(...) vou te contar algumas que não estão nos relatórios, porque eu pessoalmente estudei uma adaptação de equipamentos domésticos, nem sei que nome tem. Eu fiz uma coisa engraçada, uma é época 0 governo do Brasil resolveu participar de um encontro em Caracas, não é conforto doméstico. E aí lembraram que a CECAP tinha feito uma proposta e pediu pra CECAP fazer uma tese que foi levada a Caracas, feito com a Doutora Giselda Visconti, foi legal, porque eu aproveitei para fazer a crítica obrigatória a todo o processo. Há 40 anos atrás era um outro quadro, esse hábito que é muito comentado que a mulher 
brasileira desperdiça e joga fora, poderia ser explicado muitas vezes que uma comida em um país muito quente fora da geladeira estraga, não guarda pra dar pra criança porque vai ficar doente. Mas uma geladeira é um equipamento de saúde, e eu até imaginava uma geladeira que fosse construída embutida no processo da construção, e o fogão também assim, e chegamos a fazer, e a geladeira foi feita em São Carlos (ainda tinha lá ...28'40), a geladeira custava $R \$ 30,00$, custava menos que os enfeites de uma geladeira americana que a loja Mappin vendia, e o fogão custava $R \$ 10,00, R \$ 5,00$, meu pai tinha uma fábrica de fogão, mandei fazer um. A geladeira embutia, você põe concreto ou tijolo, isola termicamente, põe um tampa, porque a geladeira importada não cabia, nem passava na porta. Fizemos pesquisa de mobiliário, mas tudo em vão porque não pode existir uma produção industrial que não tenha sido apoiada em uma pesquisa, e a indústria não embarca nem na pesquisa quando ela tem uma garantia de uma programação de reconhecimento, porque custa muito dinheiro produzir um mobiliário que inclui tudo, cadeira, mesa, cama. Tinha aqui um cidadão muito interessante, com quem eu estudei discutindo isso, leva 8 anos pra ter uma linha de produção andando, é muito interessante, porque você tem que fazer um estudo do pé da cadeira, tem que ser padrão ao pé da mesa, como automóvel ou uma indústria qualquer, mas não tinha nenhuma possibilidade de garantia, num tinha, então tudo ficou no mundo das idéias." 29

De forma mais explicativa,o arquiteto Geraldo Vespaziano Puntoni comentou o problema de se desejar incorporar à obra determinados equipamentos, que o mercado oferece e que as pessoas, em geral possuem e/ ou compram:

\footnotetext{
"se comentava em entregar o apartamento equipado de geladeira, fogão, essas coisas todas... naquela época a família do Fábio era
}

\footnotetext{
${ }^{29}$ Entrevista de Fábio Penteado à autora em 09/ 03/ 2007.
} 
proprietária dos fogões Dako e a gente tinha feito alguns orçamentos e chegamos a conclusão de que valia a pena fazer o apartamento com esses equipamentos, mas aí surgiu uma questão, e foi contratado o serviço da mulher do Alfredo Paesani, a Eugênia Paesani. A Eugênia que era socióloga fez o levantamento de o que as pessoas que iriam entrar nos apartamentos consumiam, na época ela fez várias pesquisas nas lojas da época, tipo o que seria hoje as Casas Bahia, e ela descobriu que quem eram os maiores compradores de fogão e geladeira era essa classe. Então se chegou a conclusão que seria um absurdo as pessoas pagarem por equipamentos que elas já tinham, então a gente acabou com essa idéia de apartamento equipado." ${ }^{30}$

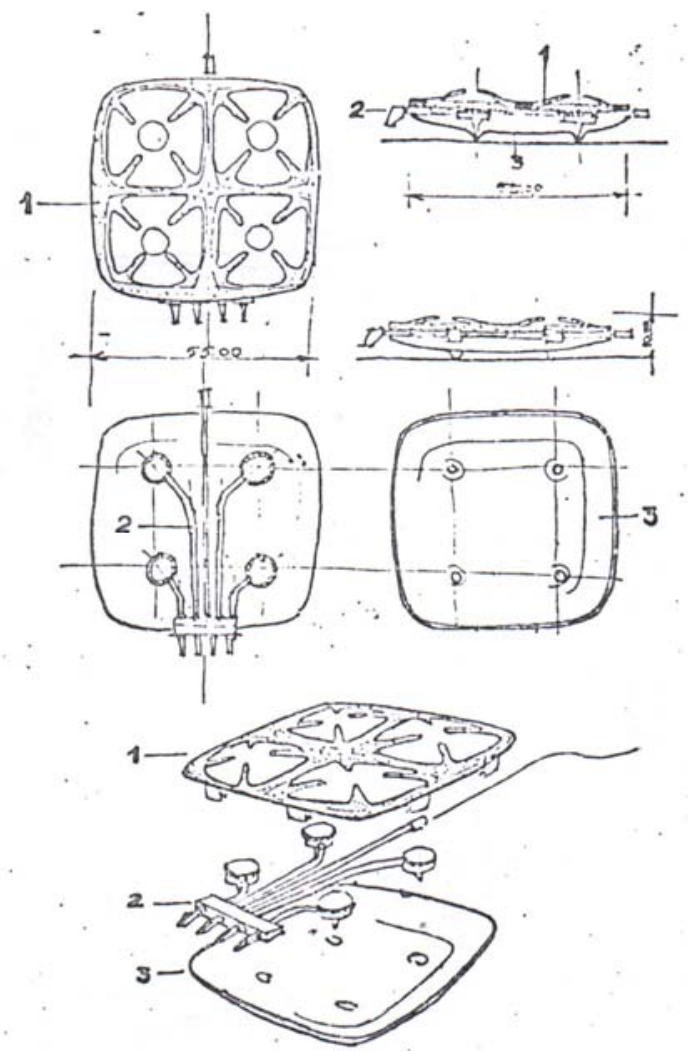

Figura 53 - Projeto Fogão Fonte: Sylvia Ficher.

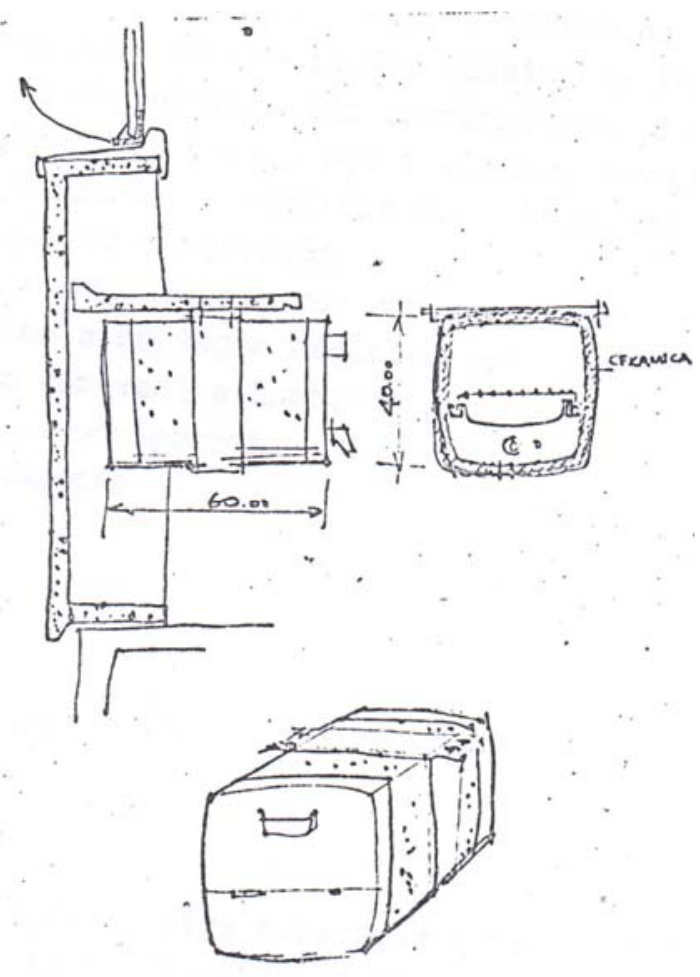

Figura 54 - Projeto Forno

Fonte: Sylvia Ficher.

\footnotetext{
${ }^{30}$ Entrevista de Geraldo Vespaziano Puntoni a autora em 17/ 07/ 2007.
} 


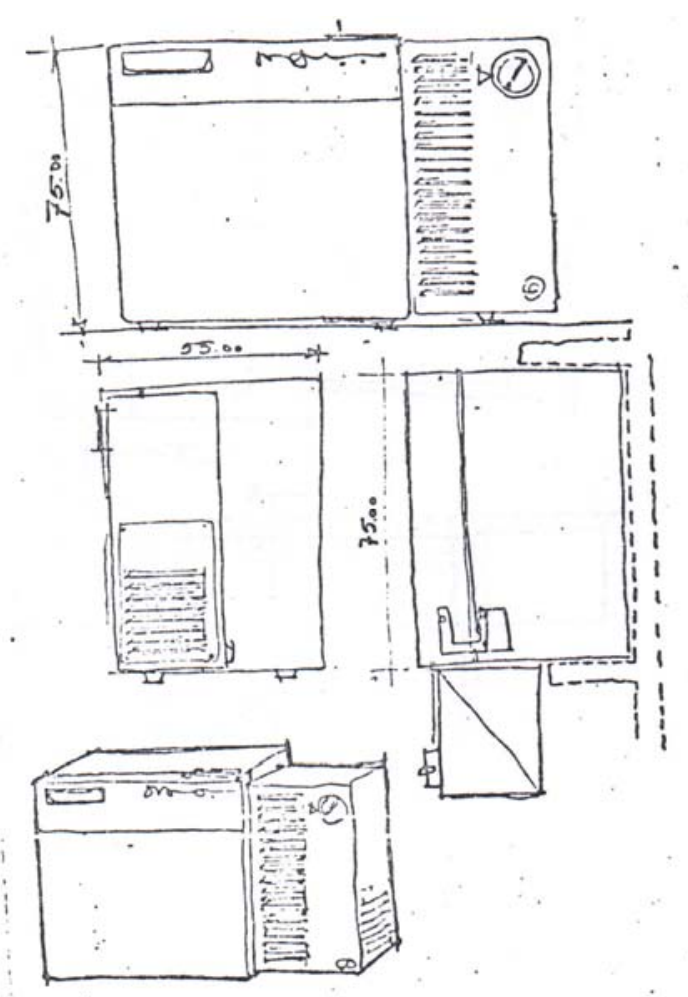

Figura 55 - Projeto Geladeira

Fonte: Sylvia Ficher.

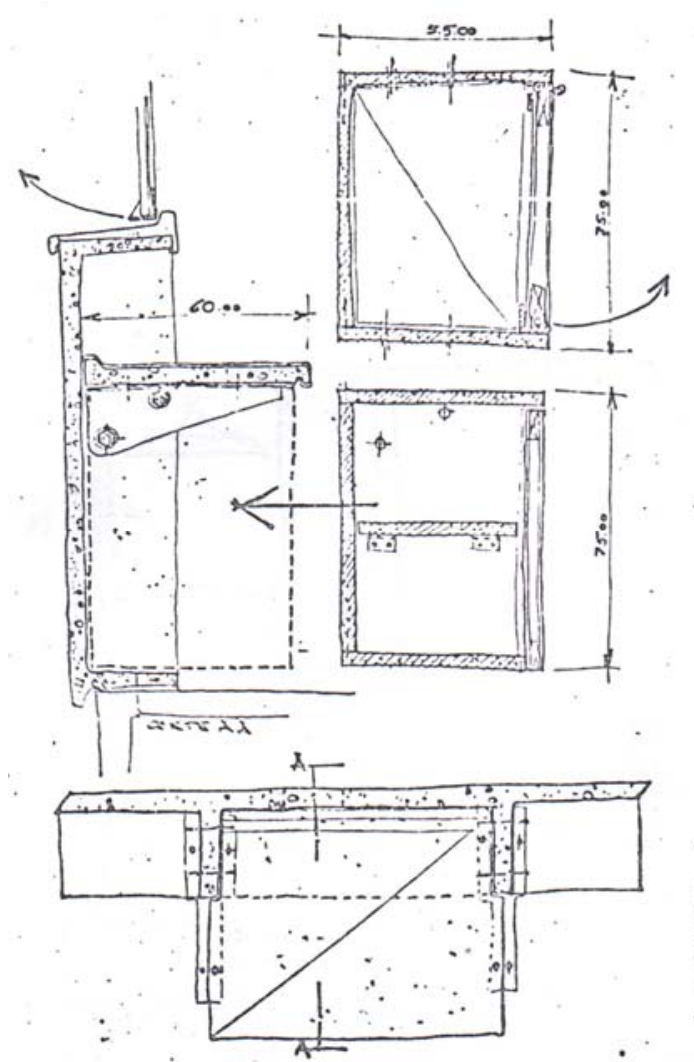

Figura 57 - Projeto Armário da área de serviços.

Fonte: Sylvia Ficher.

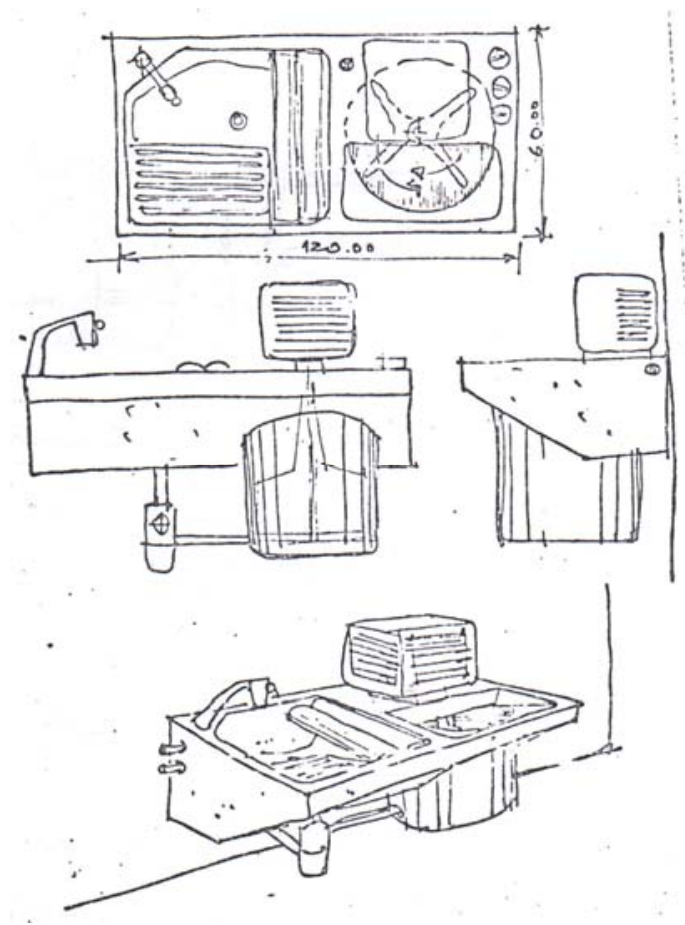

101
Figura 56 - Projeto Máquina de Lavar Fonte: Sylvia Ficher.

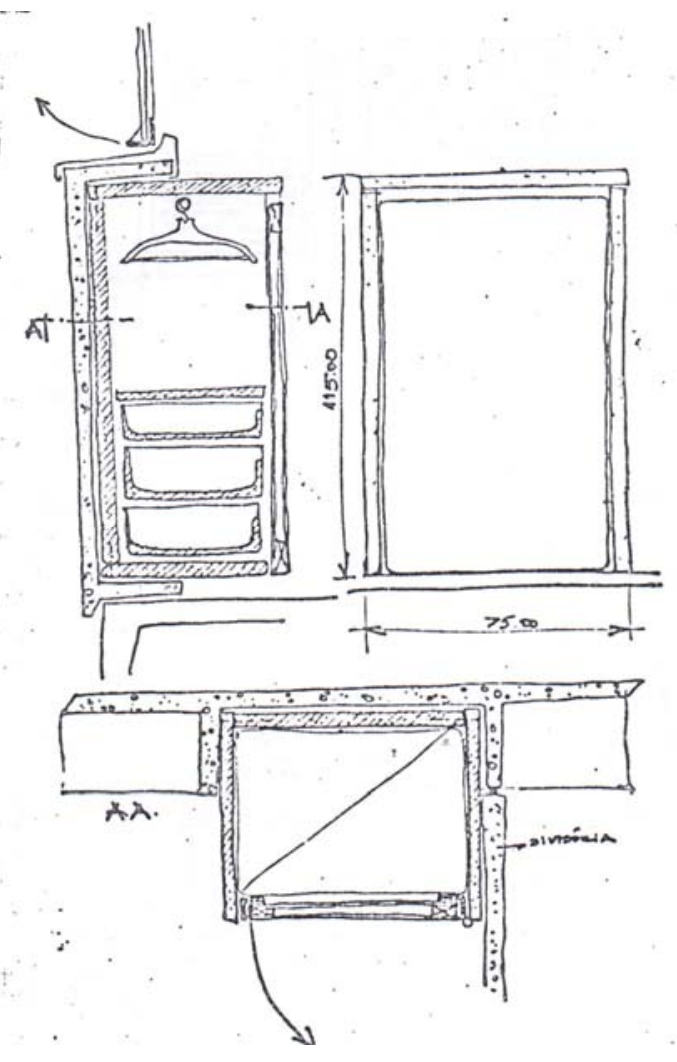

Figura 58 - Projeto Armário dos Dormitórios Fonte: Sylvia Ficher. 


\section{2므 ETAPA}

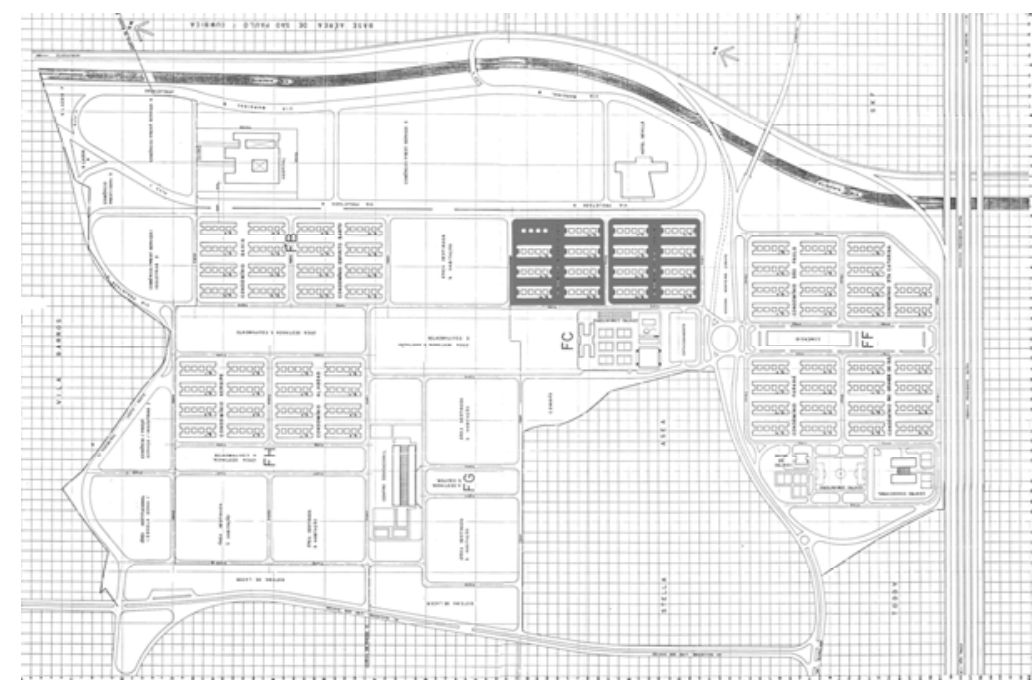

Figura 59 - Localização dos Condomínios Santa Catariana, Paraná e Rio Grande do Sul.

\section{Resumo da 2a Etapa}

\begin{tabular}{lc} 
Condomínios & $\begin{array}{c}\text { Minas Gerais e } \\
\text { Rio de J aneiro }\end{array}$ \\
\hline Blocos & 16 \\
\hline Unidades Habitacionais & 960 \\
\hline Fase & III \\
\hline Período & 1972 a 1976 \\
\hline
\end{tabular}

Nesta etapa, constituída pela construção de 16 blocos, distribuídos da seguinte maneira: Condomínio Minas Gerais (8 blocos, 480 unidades habitacionais) e Condomínio Rio de Janeiro (8 blocos, 480 unidades habitacionais). Estes blocos fariam parte da freguesia FC.

Em relação à primeira, essa etapa tem como características principais, a mudança na viga de fechamento do primeiro andar. A parte de blocos que se fechavam os armários passa a ser uma viga longitudinal que percorre 0 edifício todo, deixando os pilares mais alongados. Isso foi necessário devido a 
trincas e rachaduras que a parte em balanço dos armários, causou na $1^{\mathrm{a}}$ etapa.

Na primeira etapa da construção, na fachada, o balanço em que se projeta os armários, foram feitos segmentados, já nas etapas seguintes esse balanço é contínuo (SAVIOLI, 2007) ${ }^{31}$.

Outra mudança, que também é bem visível, é a mudança no projeto da caixa de escada, o que na $1^{\text {a }}$ Etapa tinha formato de " $U$ ", agora se faz de em lances paralelos de escadas (figura 60), com pequena mudança nos dutos, que ainda continuam dentro de um shaft, e com a inserção de um banco no hall de apartamentos.

Nessa etapa foi feita a primeira tentativa de escada pré-fabricada, podendo-se notar (figura 64 e 65) isso com as perfurações no concreto dos guarda- corpos, marcado pelas formas de metálicas empregadas na montagem. As formas metálicas também são desenvolvidas nessa etapa pela construtora Rossi para facilitar o trabalho na hora da montagem da estrutura, além do concreto aparente ficar com uma aparência muito melhor. Vestígios das formas (figura 68) são observados ainda nos dias de hoje nas fachadas dessa fase, no balanço dos armários.

Por fim, os caixilhos adotados foram os de alumínio por um problema de ferrugem que apareceu nos da primeira etapa, em função de um tipo de chuva ácida que na década de 1970 já atingia a região de Guarulhos (GONÇALVES, 2007) ${ }^{32}$.

Foi então que as pesquisas se voltaram para os caixilhos. Falcão Bauer, desenvolveu um equipamento que simulava chuvas, ventos, ruídos, e todos os caixilhos que tinham no mercado foram testados e não obtiveram resultado positivo. Para as etapas seguintes, foi feita uma licitação de caixilhos, ganha pelo Liceu de Artes e Ofícios de São Paulo (GONÇALVES, 2007) ${ }^{33}$.

\footnotetext{
31 idem.

32 Entrevista de Fernando Gonçalves à autora em 05/ 04/ 2007.

33 idem.
} 


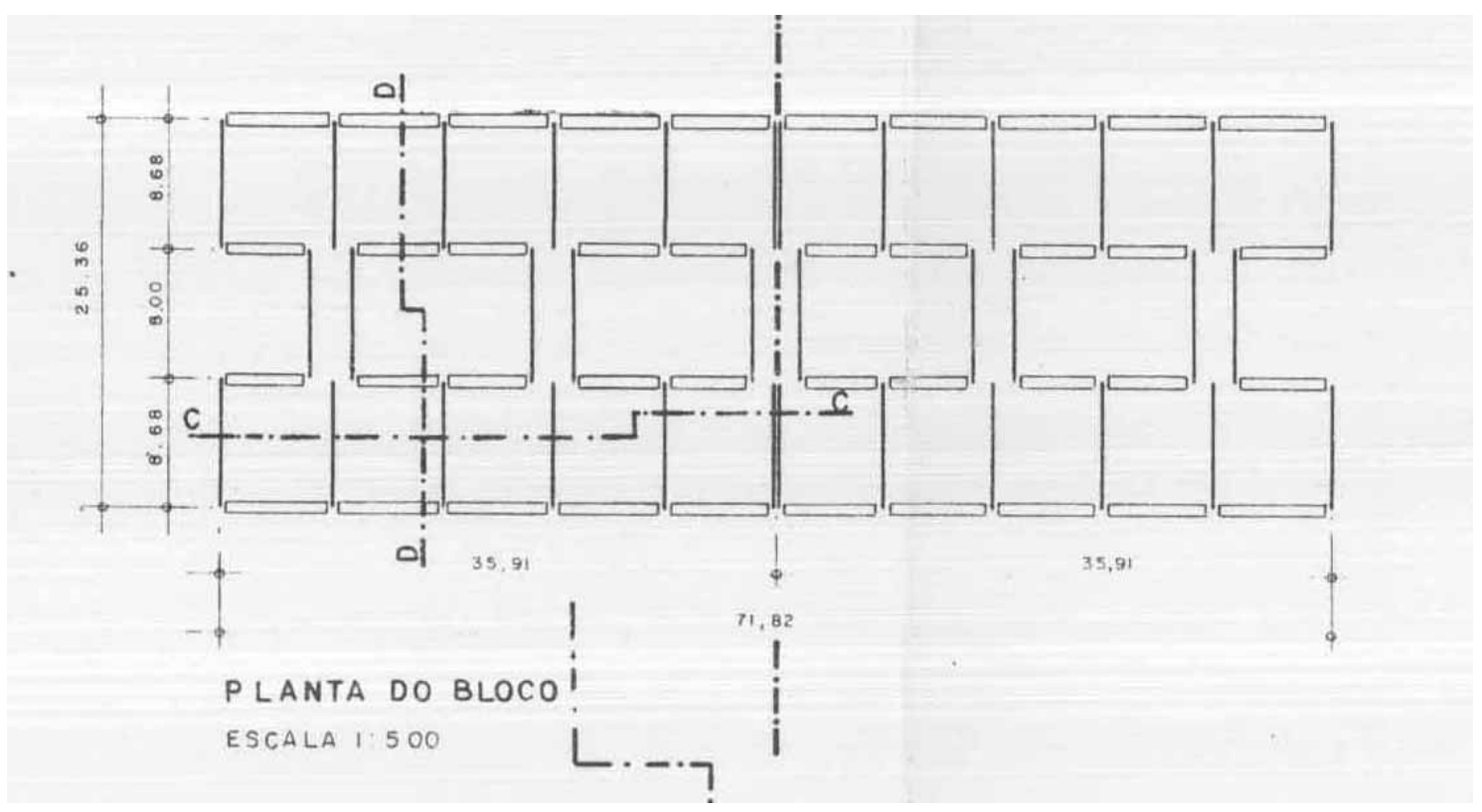

Figura 60 - Vista do bloco com escada de lance único de escada.

Fonte: Arquivo CDHU.

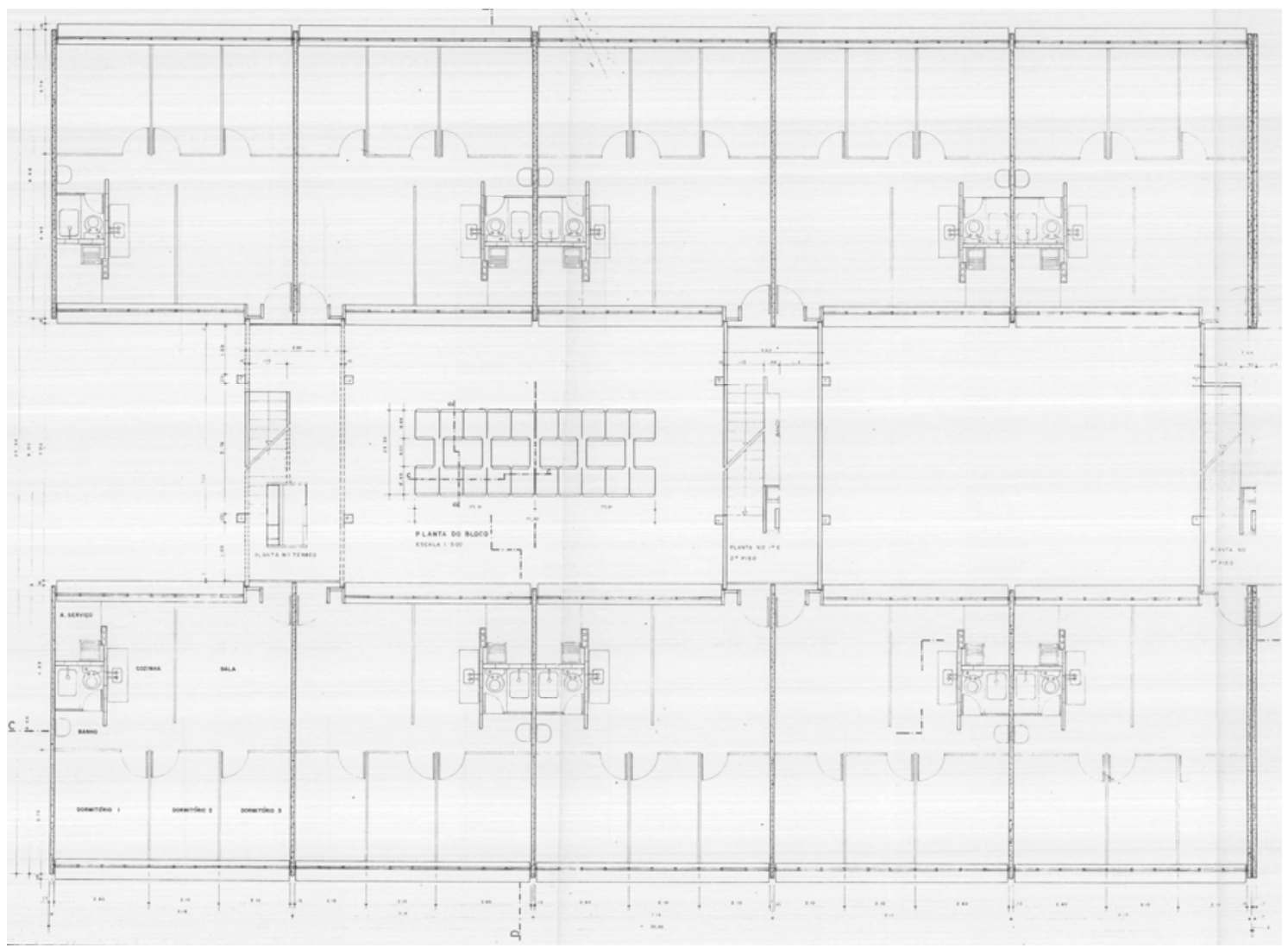

Figura 61 - Detalhe do bloco com escada de lance único de escada.

Fonte: Arquivo CDHU. 


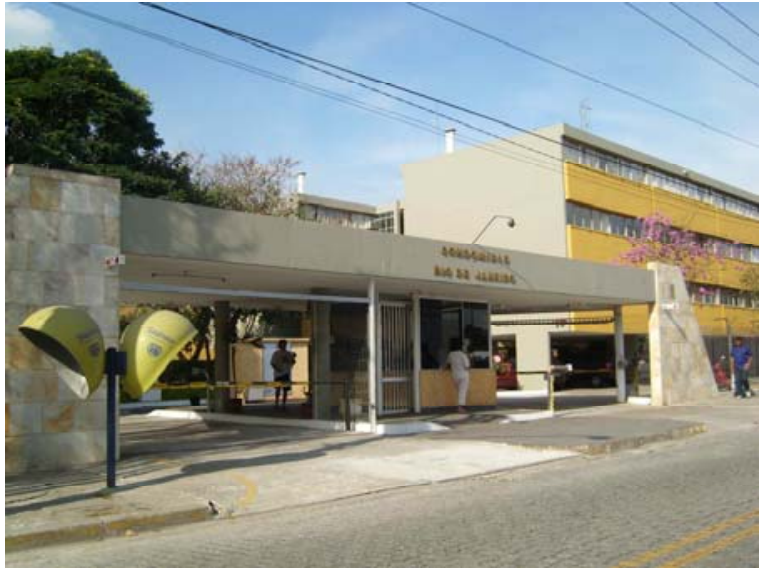

Figura 62 - Portaria Condomínio Rio de J aneiro.

Fonte: Fabiana Cerávolo.

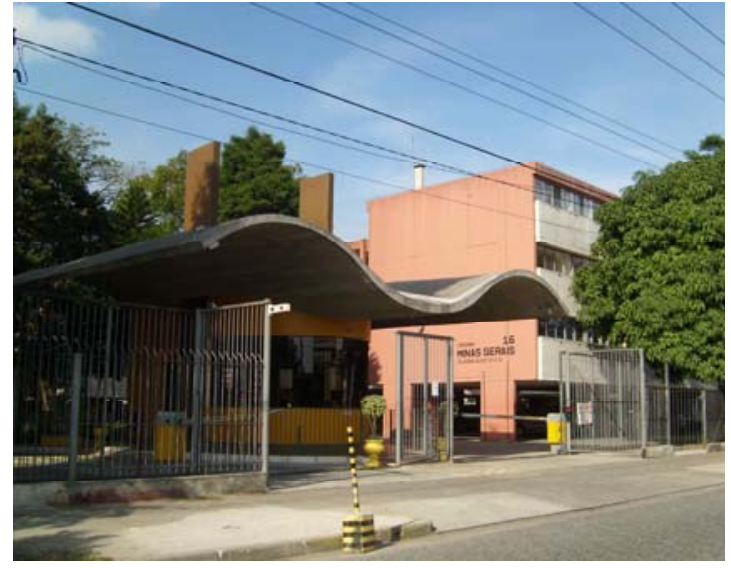

Figura 63 - Portaria Condomínio Minas Gerais.

Fonte: Fabiana Cerávolo.

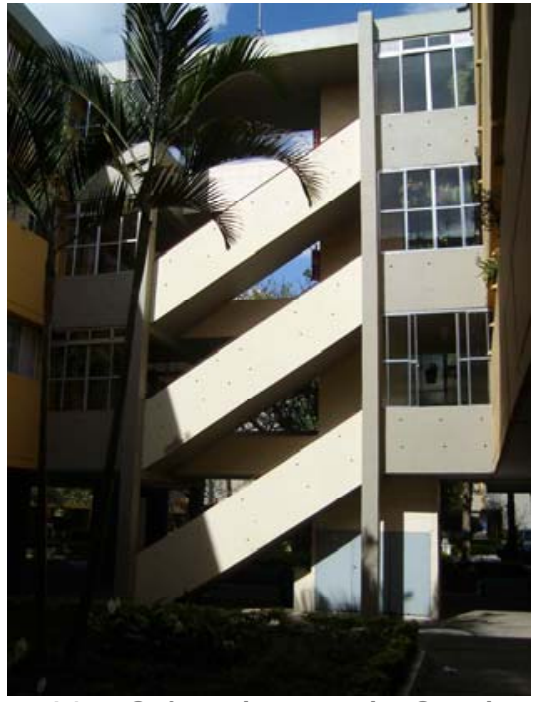

Figura 64 - Caixa de escada Condomínio Rio de J aneiro.

Fonte: Fabiana Cerávolo.

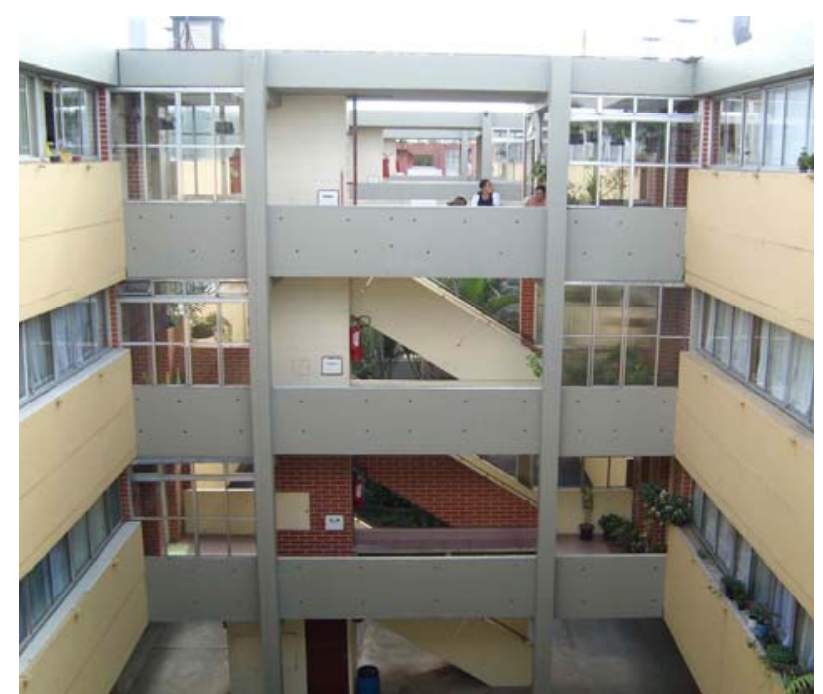

Figura 65 - Caixa de escada Condomínio RJ, vista inversa.

Fonte: Fabiana Cerávolo. 


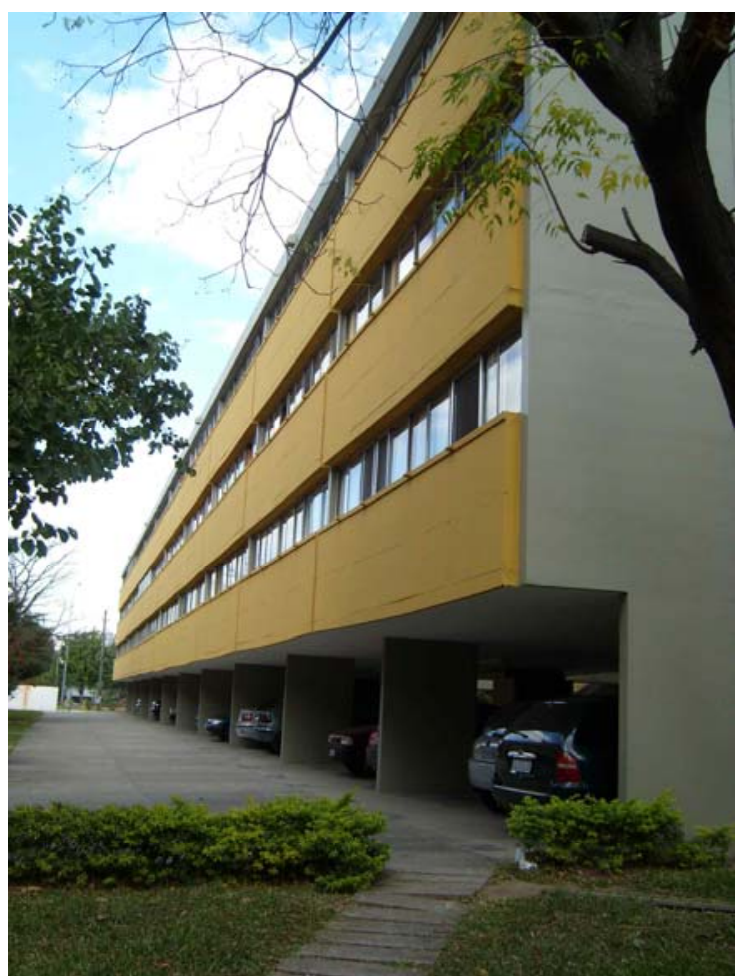

Figura 66 - Fachada Condomínio Rio de $J$ aneiro.

Fonte: Fabiana Cerávolo.

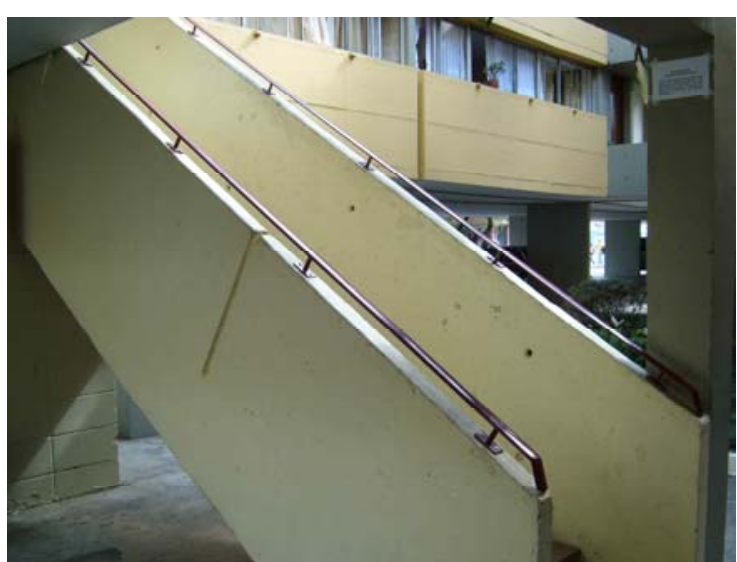

Figura 68 - Detalhe escada

Fonte: Fabiana Cerávolo.

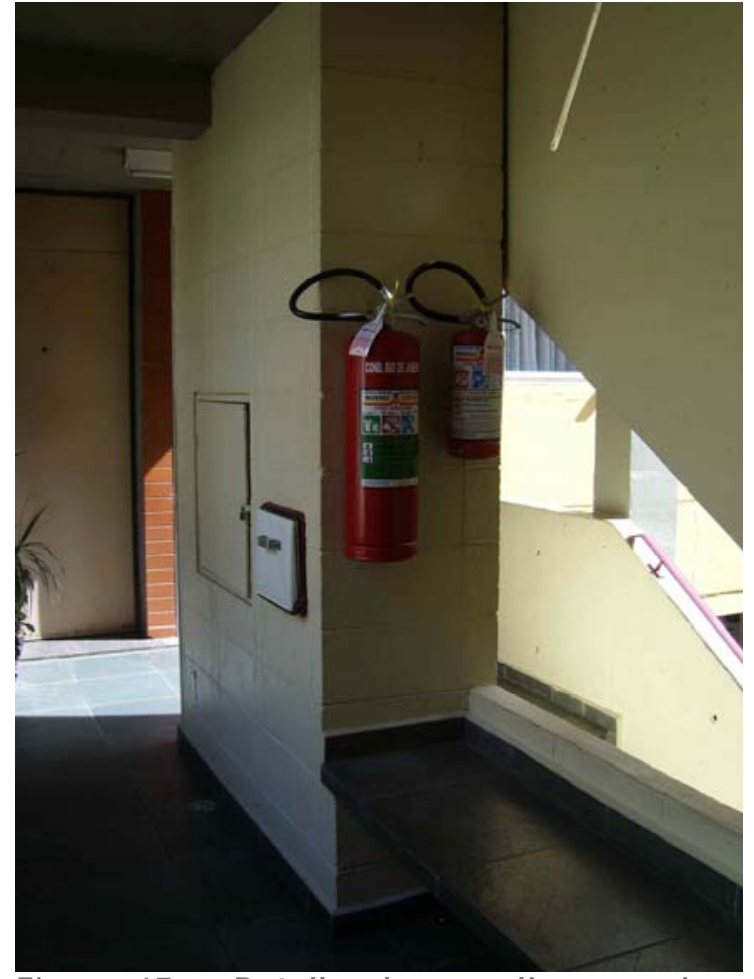

Figura 67 - Detalhe banco, lixo e caixa elétrica.

Fonte: Fabiana Cerávolo.

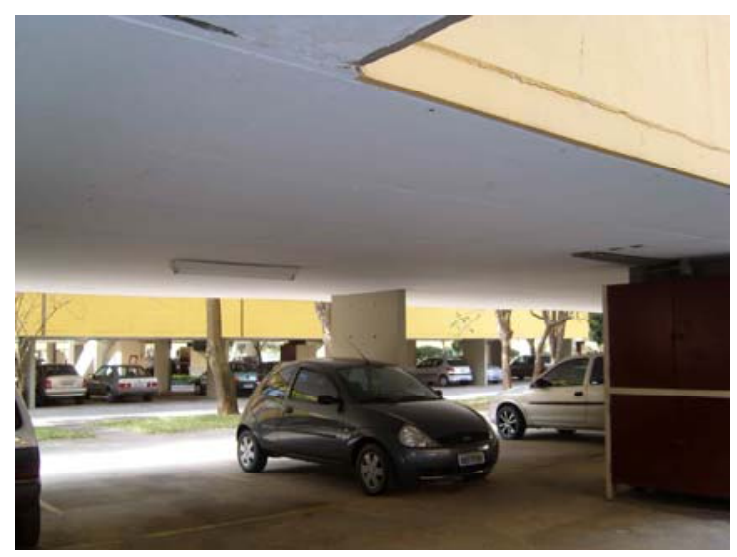

Figura 69 - piso térreo sob pilotis.

Fonte: Fabiana Cerávolo. 


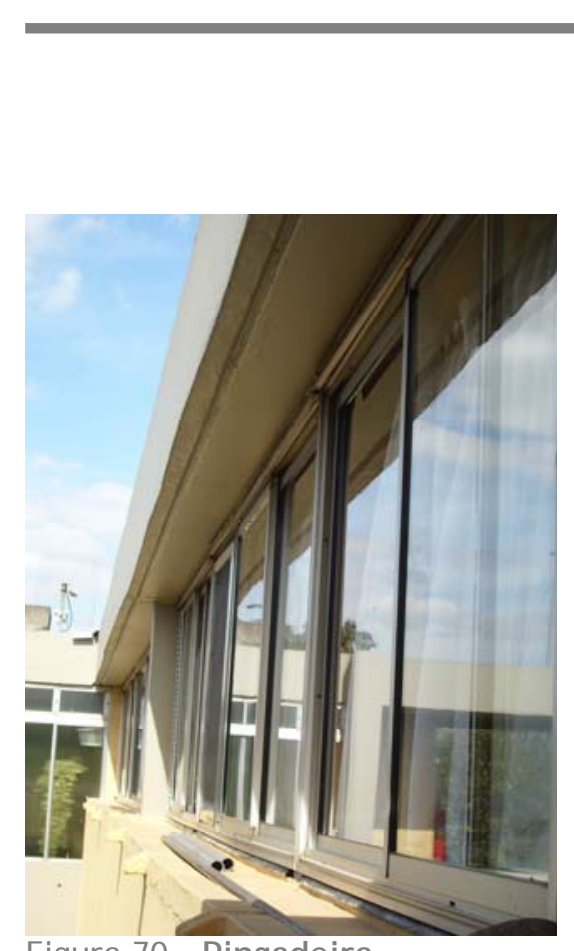

Figura 70 - Pingadeira.

Fonte: Fabiana Cerávolo.

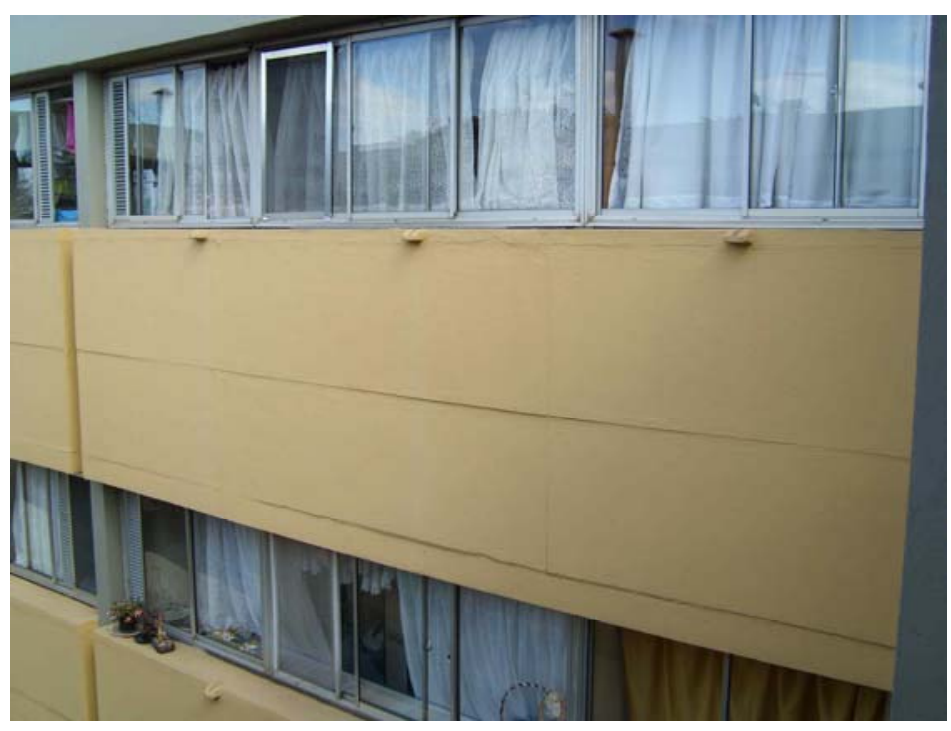

Figura 71 - Caixilhos de alumínio e marcas das formas. Fonte: Fabiana Cerávolo. 


\section{3a ETAPA}

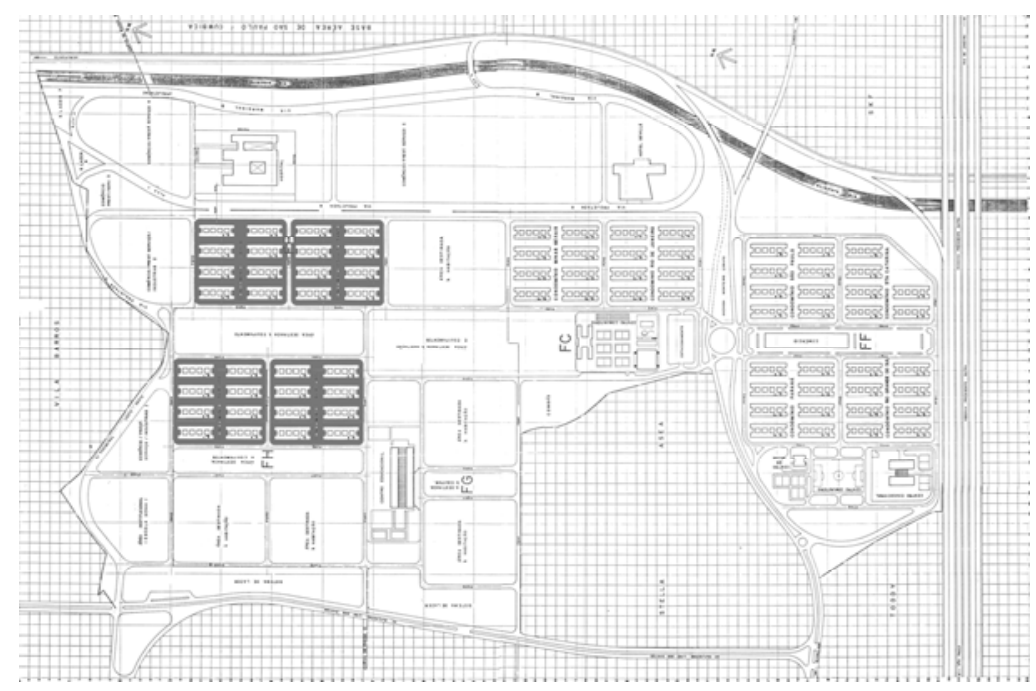

Figura 72 - Localização dos Condomínios Minas Gerais, Rio de J aneiro, Bahia, Espírito Santo, Sergipe e Alagoas.

\section{Resumo da 3ạ Etapa}

Condomínios

Bahia, Espírito Santo, Sergipe e Alagoas.

\begin{tabular}{lc}
\hline Blocos & 32 \\
\hline Unidades Habitacionais & 1920 \\
\hline Fase & IV e V \\
\hline Periodo & 1978 a 1981 \\
\hline
\end{tabular}

Nesta etapa, constituída pela construção de 32 blocos, distribuídos da seguinte maneira: Condomínio Bahia (8 blocos, 480 unidades habitacionais), Condomínio Espírito Santo (8 blocos, 480 unidades habitacionais), Condomínio Sergipe (8 blocos, 480 unidades habitacionais) e Condomínio Alagoas (8 blocos, 480 unidades habitacionais). Estes blocos fariam parte da freguesia FB e FH.

Da segunda para a terceira etapa foram alterados dois itens importantes. 0 primeiro com relação ao novo sistema de formas metálicas em 
U para a parte estrutural, chamado de Sistema Outinord, que venceu a licitação com preço mais baixo que o sistema tradicional (VISCONTI, 2007) ${ }^{34}$. Por conta, dessa mudança, a caixa de escada teve que ser recalculada inúmeras vezes, pois o guindaste não conseguia colocar a escada entre os blocos, além da dificuldade do encaixe da escada com o novo tipo de forma. E a escada (figura 73, 79 e 80), nesta etapa ficou um pouco mais leve, com um guarda-corpo vazado.

Outro item importante dessa etapa foi a entrega das unidades habitacionais com os vãos de armários com portas (VISCONTI, 2007) ${ }^{35}$.

Nesta fase muito material já tinha sido estudado e pesquisado, trazendo uma maior agilidade de construção. Não foram feitos muitos testes, mas foram aplicados os componentes da obra do jeito mais simples para se conseguir o menor preço, buscando minimizar os efeitos do descontrole inflacionário do período.

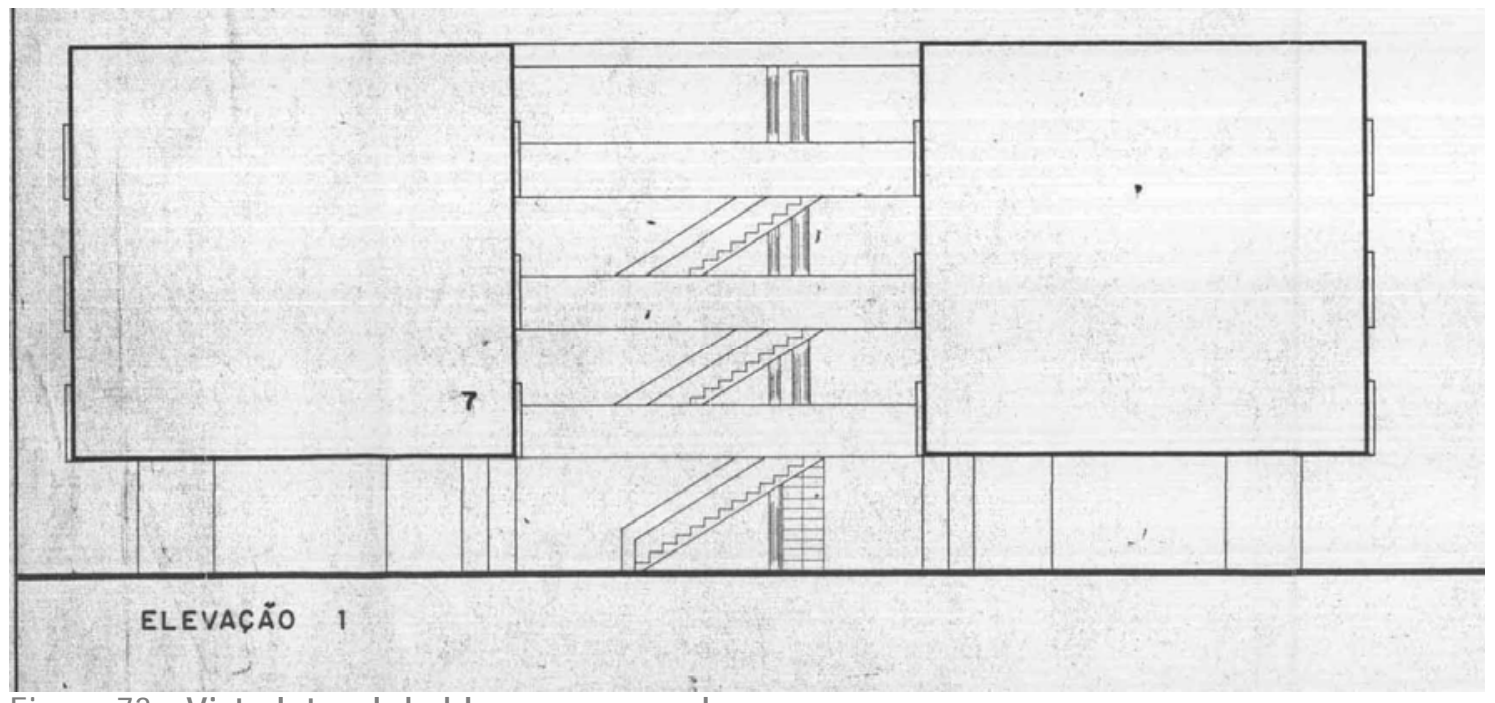

Figura 73 - Vista lateral do bloco com escadas.

Fonte: Arquivo CDHU.

${ }_{35}^{34}$ Entrevista de Maria Giselda Visconti à autora em 09/04/2007 


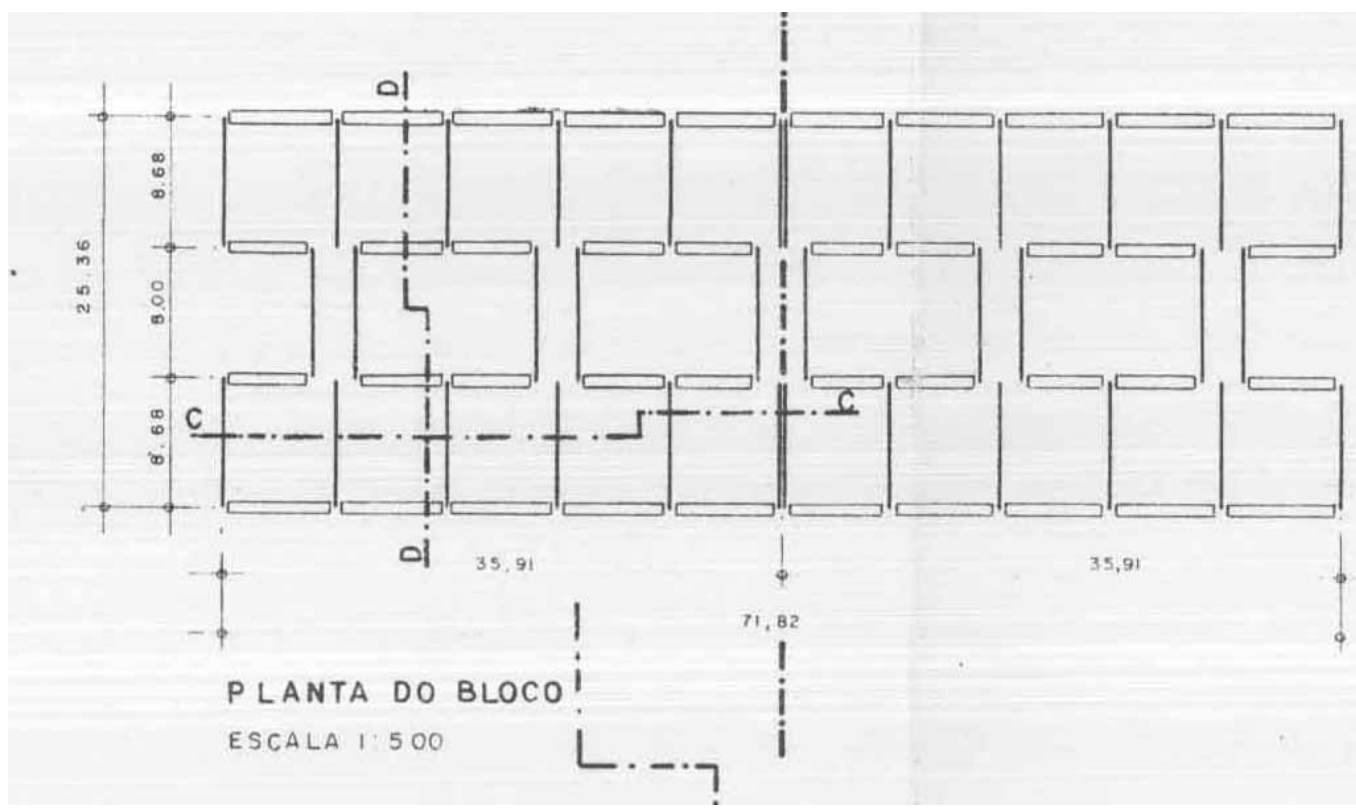

Figura 74 - Vista do bloco com escada de lance único de escada.

Fonte: Arquivo CDHU.

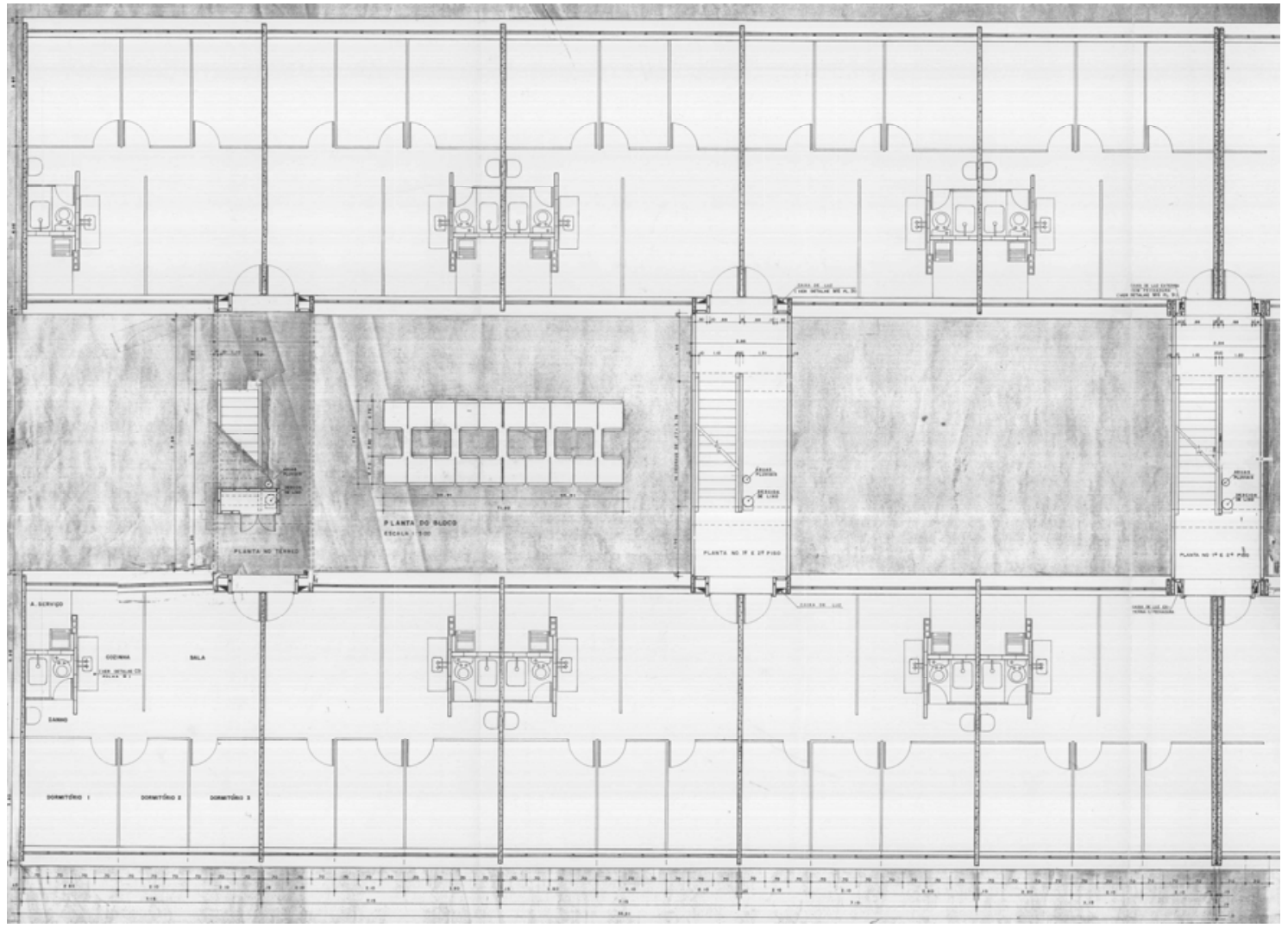

Figura 75 - Detalhe do bloco com escada de lance único de escada. Fonte: Arquivo CDHU. 


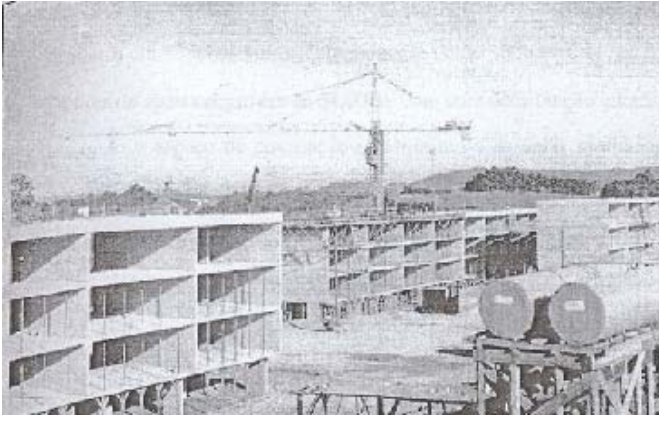

Figura 76 - Vista da fase de construção do conjunto.

Fonte: Arquivo CDHU.

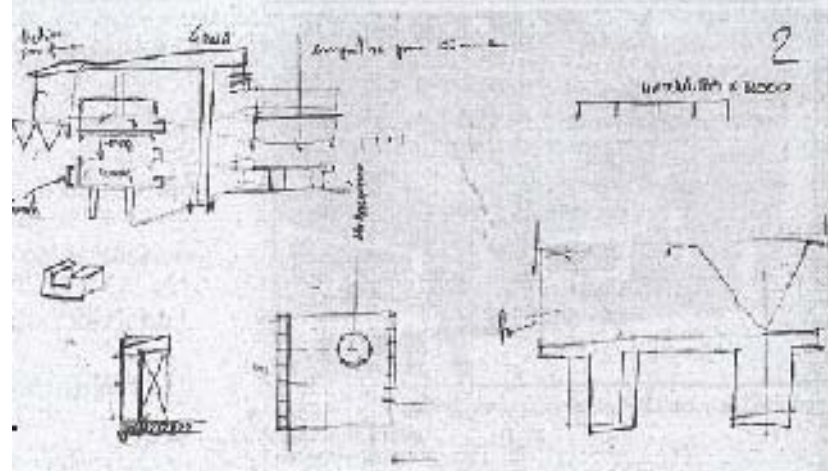

Figura 77 - Croquis da montagem de estrutura pré-fabricada.

Fonte: Arquivo CDHU.

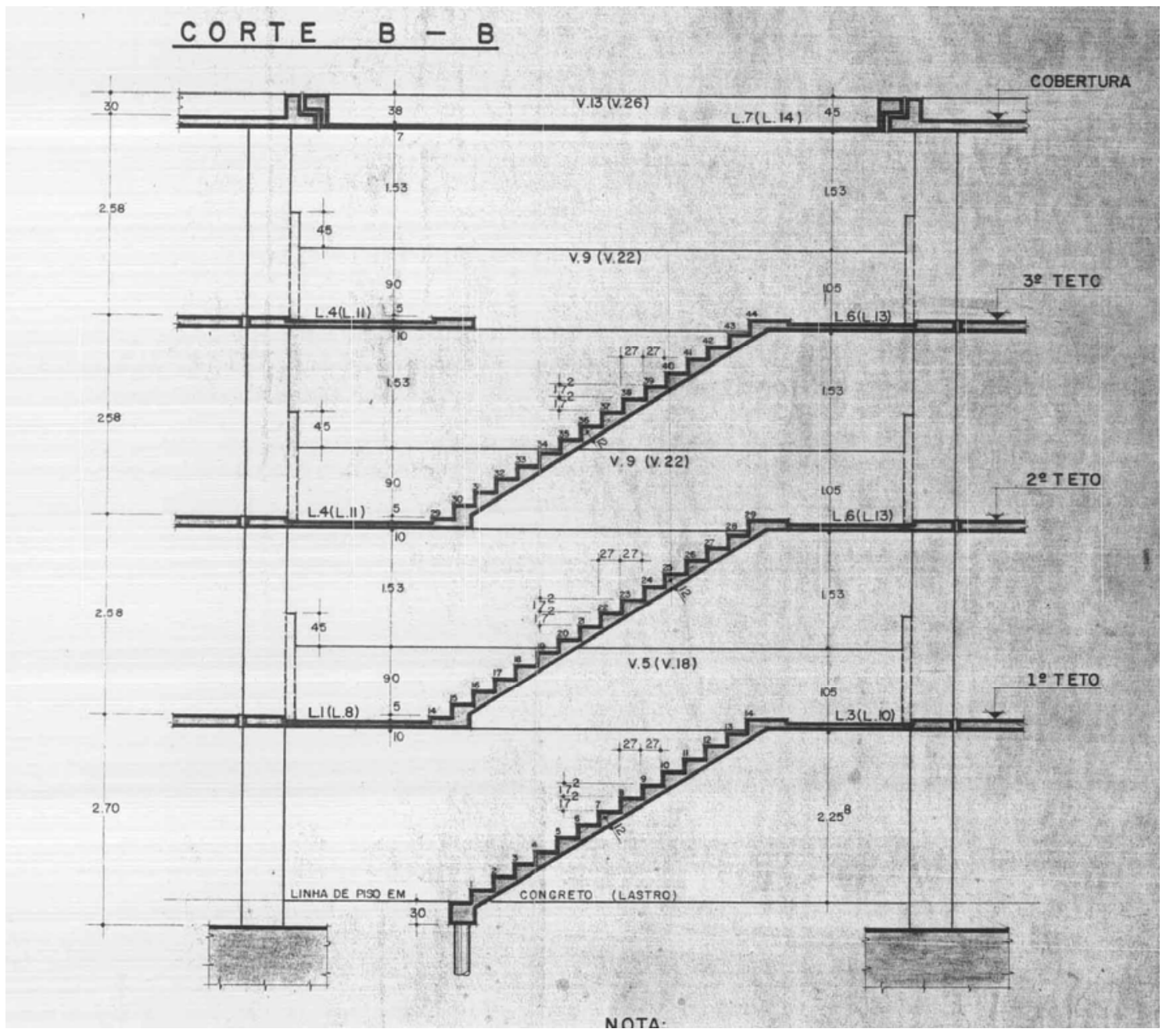

Figura 78 - Corte do bloco com escada de lance único de escada com detalhe estrutural. Fonte: Arquivo CDHU. 


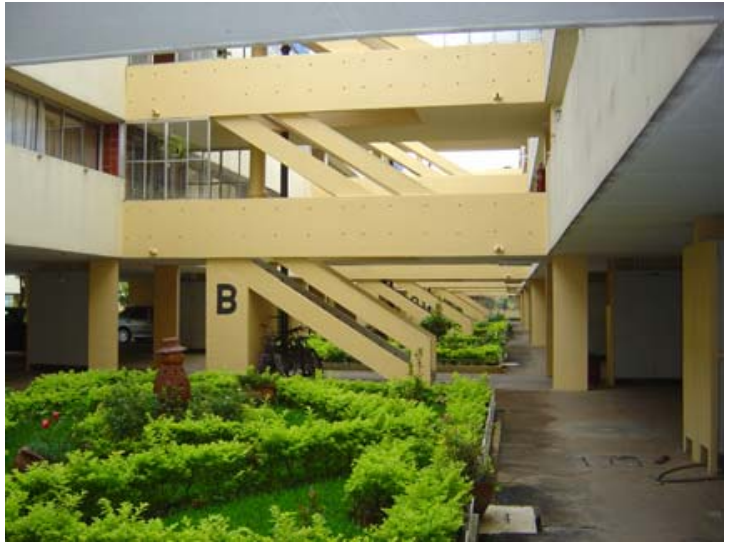

Figura 79 - Vista entre blocos e escada com guarda-corpo vazado.

Fonte: Fabiana Cerávolo.

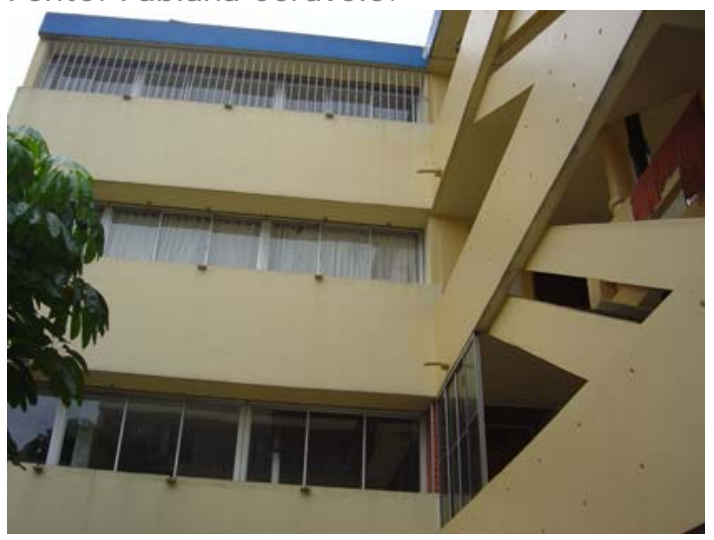

Figura 79 - Fachada com esquadria de alumínio.

Fonte: Fabiana Cerávolo.

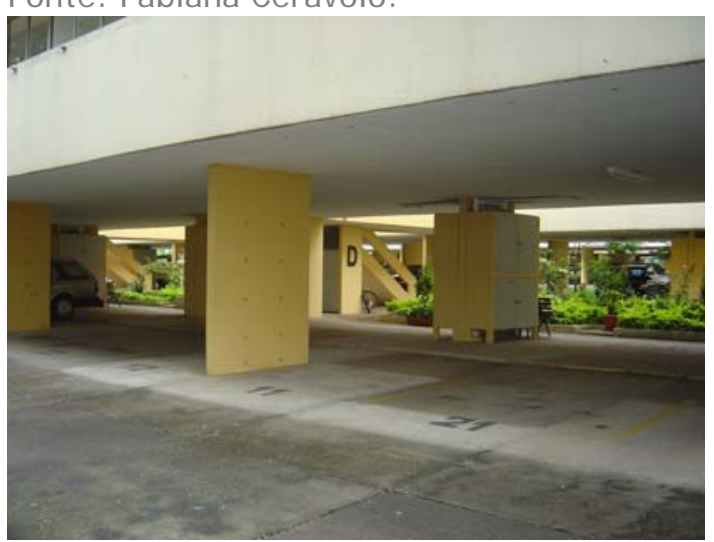

Figura 81 - Garagem sob pilotis com pilar mais comprido.

Fonte: Fabiana Cerávolo.

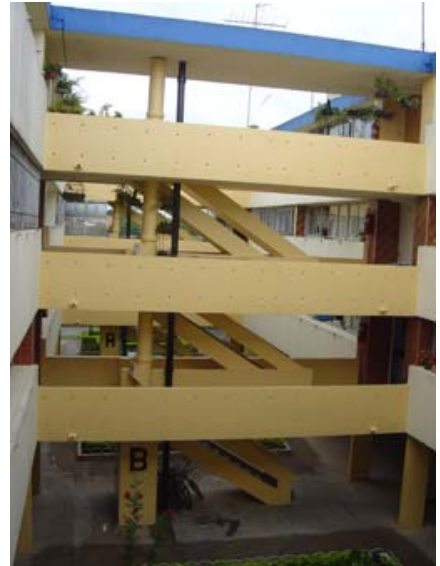

Figura 80 - Vista posterior entre blocos e escada com guarda-corpo vazado.

Fonte: Fabiana Cerávolo.

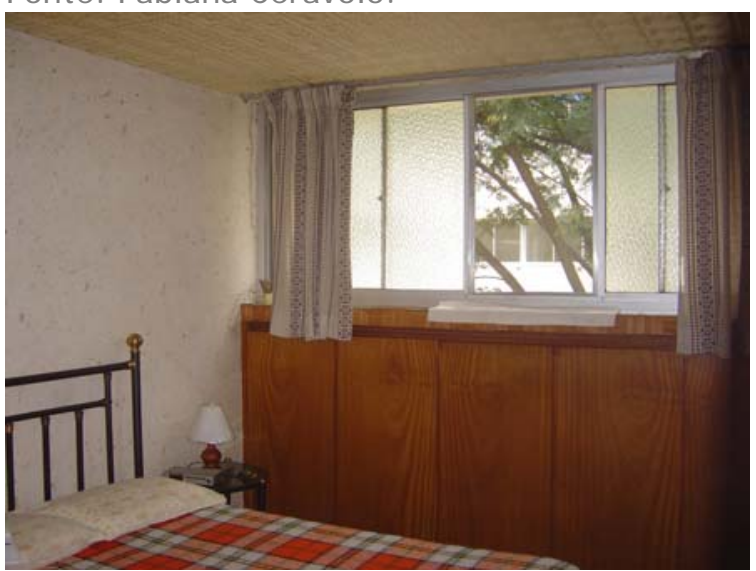

Figura 80 - Vista interna da unidade armários com portas.

Fonte: Fabiana Cerávolo.

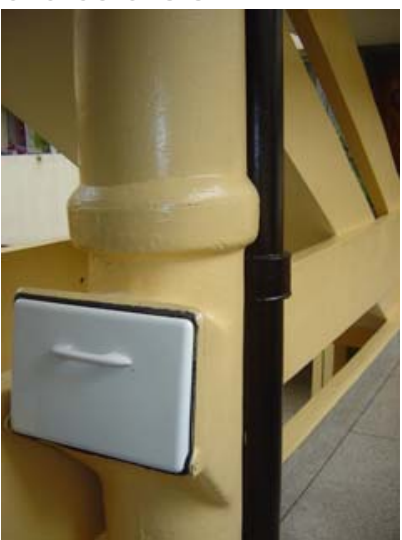

Figura 82 - Detalhe da Lixeira. Fonte: Fabiana Cerávolo. 


\section{Áreas e Equipamentos Coletivos}

Abaixo estão apresentados as áreas e Equipamentos Coletivos que foram realizados juntamente com as habitações.

- Centro de Abastecimento Zezinho Magalhães Prado

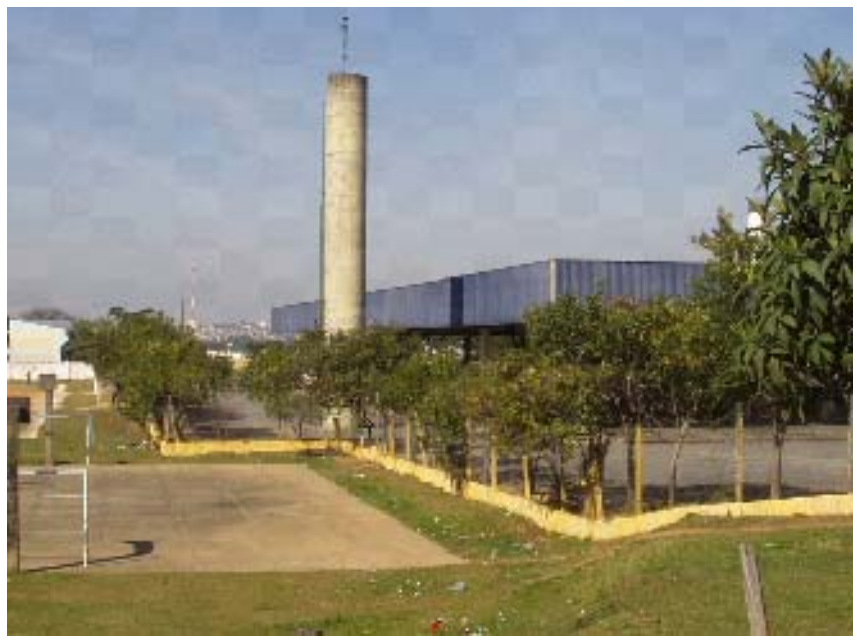

Figura 83 - Centro de Abastecimento do Parque CECAP.

Fonte: Solimar Mendes Isaac.

O Centro de Abastecimento é usado por uma população mais ampla que do Parque CECAP, com funcionamento aos sábados das 6 h00 às 13h00. 0 espaço ainda é usado pra outras finalidades como feiras de automóveis e shows. 
- Centro de Saúde

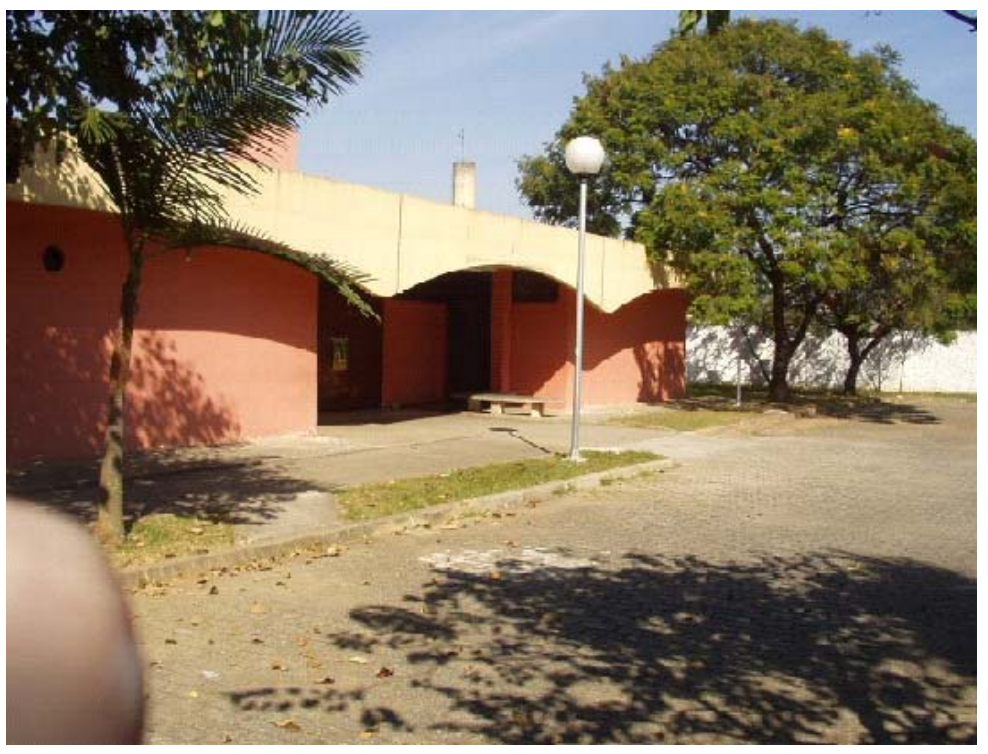

Figura 84 - Centro de Saúde. Fonte: Solimar Mendes Isaac.

- Praça Mamonas Assassinas

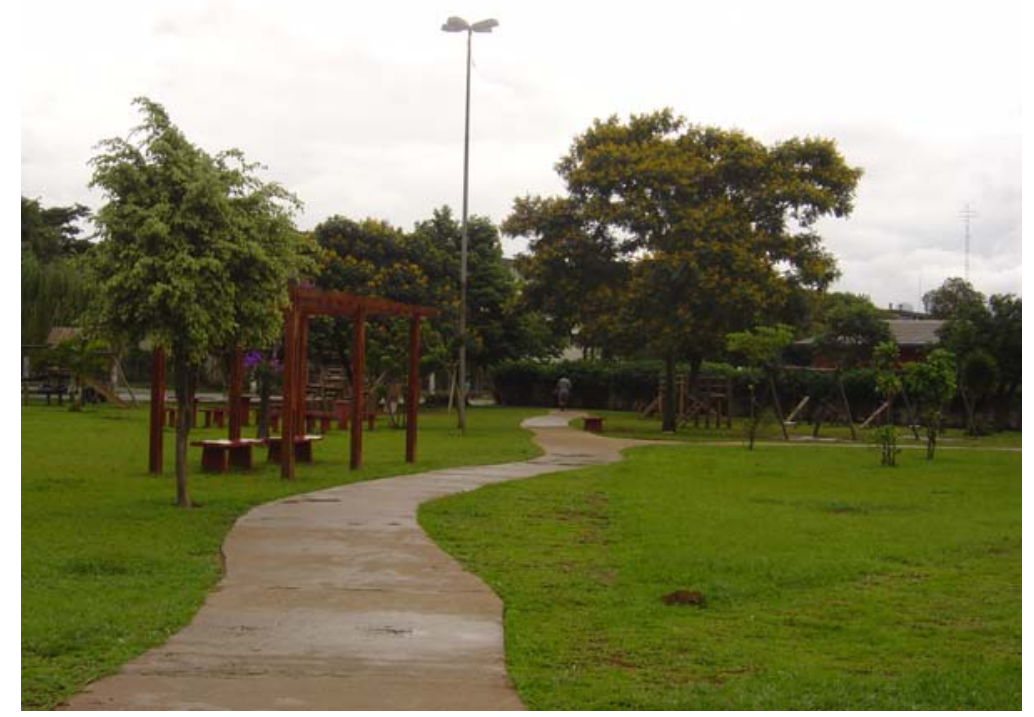

Figura 85 - Praça Mamonas Assassinas.

Fonte: Fabiana Cerávolo.

Praça de grande utilização pelos moradores do bairro, com um público de crianças e adolescentes, por estar próximas as duas escolas públicas. 
- Campo de Futebol e Quadras Poliesportivas

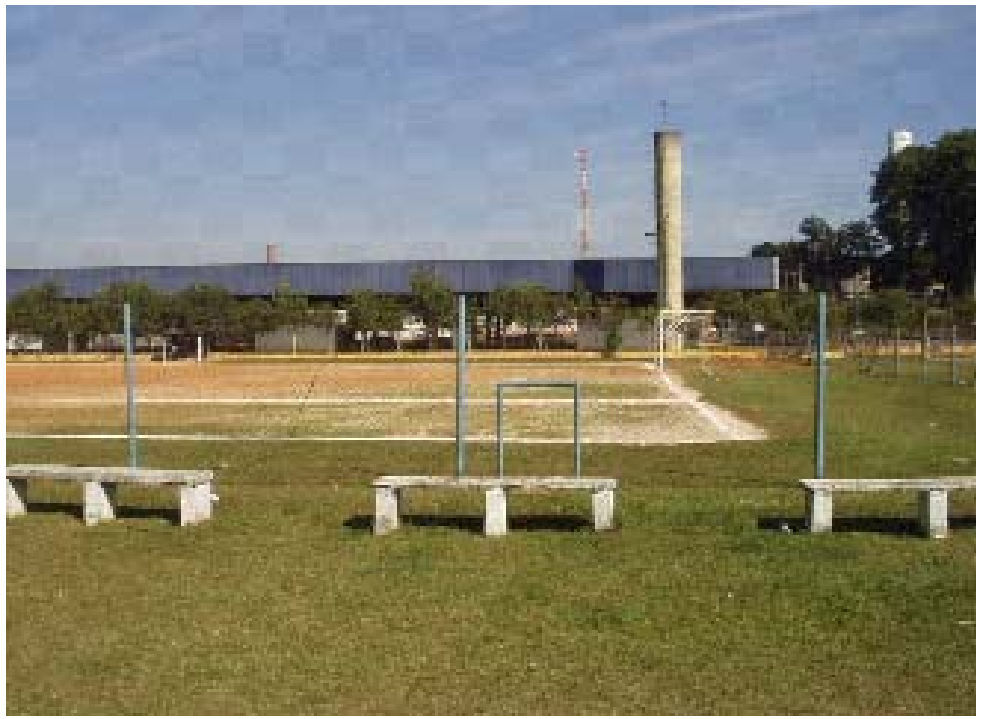

Figura 86 - Campos de Futebol Fonte: Solimar Mendes Isaac.

Foram construídas essa praça de esportes com um campo de futebol e três quadras, na gestão Paulo Egydio Martins, em 1977. O espaço é de utilização intensa pela população local (ISSAC, 2007).

- Escolas

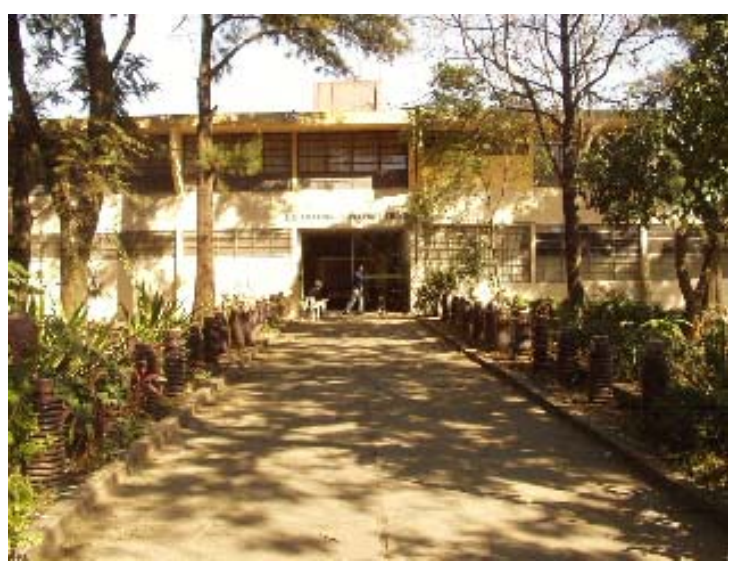

Figura 86 - EEPSG Francisco Antunes Filho Fonte: Solimar Mendes Isaac.

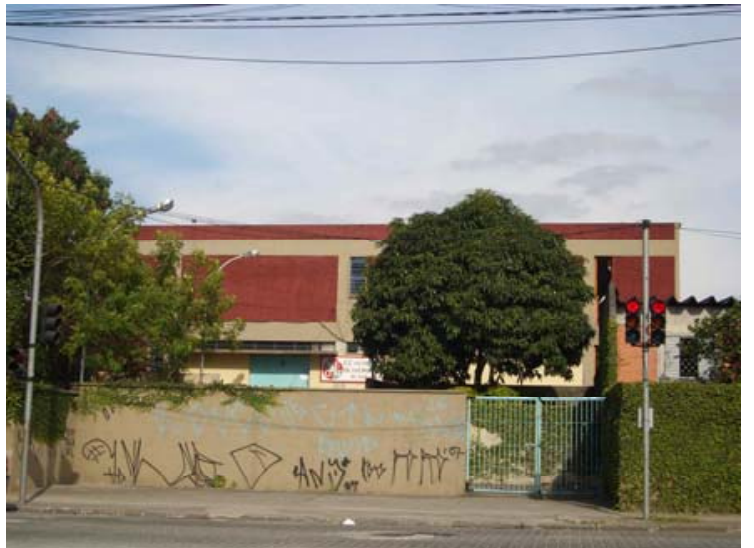

Figura 87 - Complexo de Escolas (EEPSG Vereador Elido de Oliveira Neves, CEFAM e EEPG Leopoldo Gentil J unior)

Fonte: Fabiana Cerávolo. 
As escolas são utilizadas por moradores do Bairro, mas também por moradores de bairros vizinhos, além dessas escolas estaduais, tem uma escola privada, o Colégio Machado de Assis, de Ensino Fundamental e Médio.

- Hospital Geral

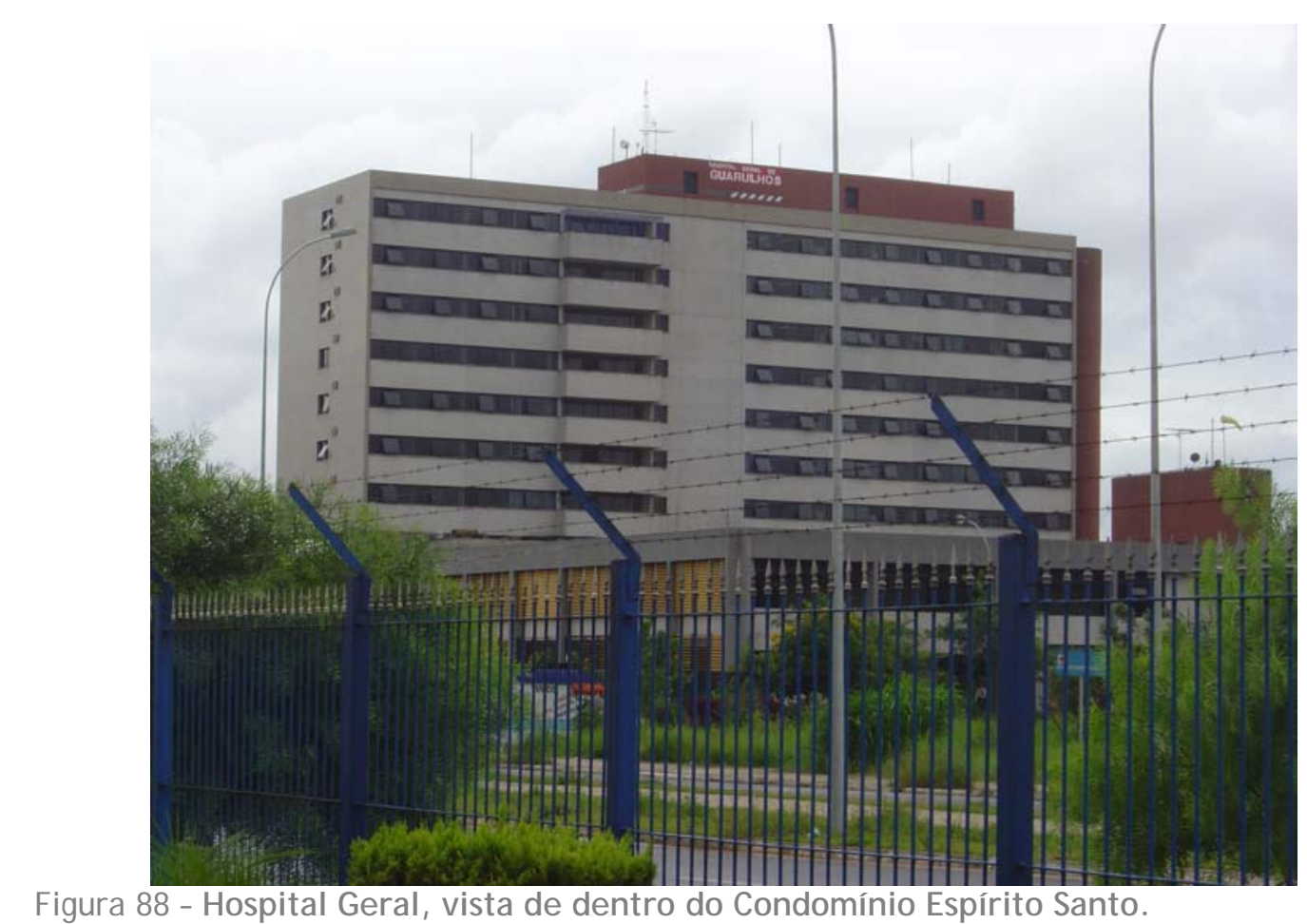

Fonte: Fabiana Cerávolo.

O Hospital Geral é referência em Guarulhos, contendo as mais diversas especialidades, atendendo principalmente a população mais carente (ISAAC, 2007). 


\section{- Centro Comunitário do Parque CECAP}

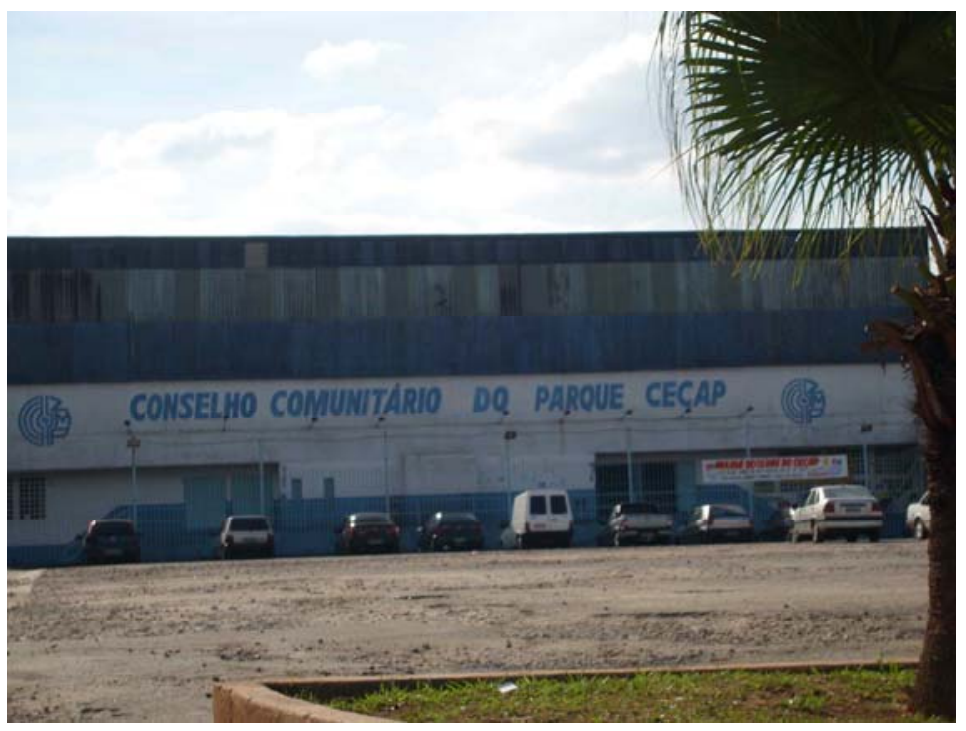

Figura 89 - Centro

Comunitário

Fonte: Fabiana Cerávolo.

Esse Centro Comunitário é um equipamento muito amplo, que contém piscinas, quadras poliesportivas, quadras de bocha, churrasqueiras, ginásio coberto, saunas e lanchonetes. Esse equipamento no bairro é chamado de Clube, e de fato é necessário a compra de um título para o seu uso.

\section{Situação Atual}

Atualmente, conforme o censo de 2000, o Conjunto é formado por 10 condomínios totalizando 4.680 apartamentos e a população é de 15.226 habitantes (ver figura 06). Com relação à projeção inicial foram construídos $44,15 \%$ do total. Na época da construção o déficit anual de moradia na Grande São Paulo era de 133.000 unidades, com crescimento anual de 72.000 unidades. A população das áreas situadas a menos de $10 \mathrm{~km}$ do Conjunto chegava a 2.800.000 habitantes. 


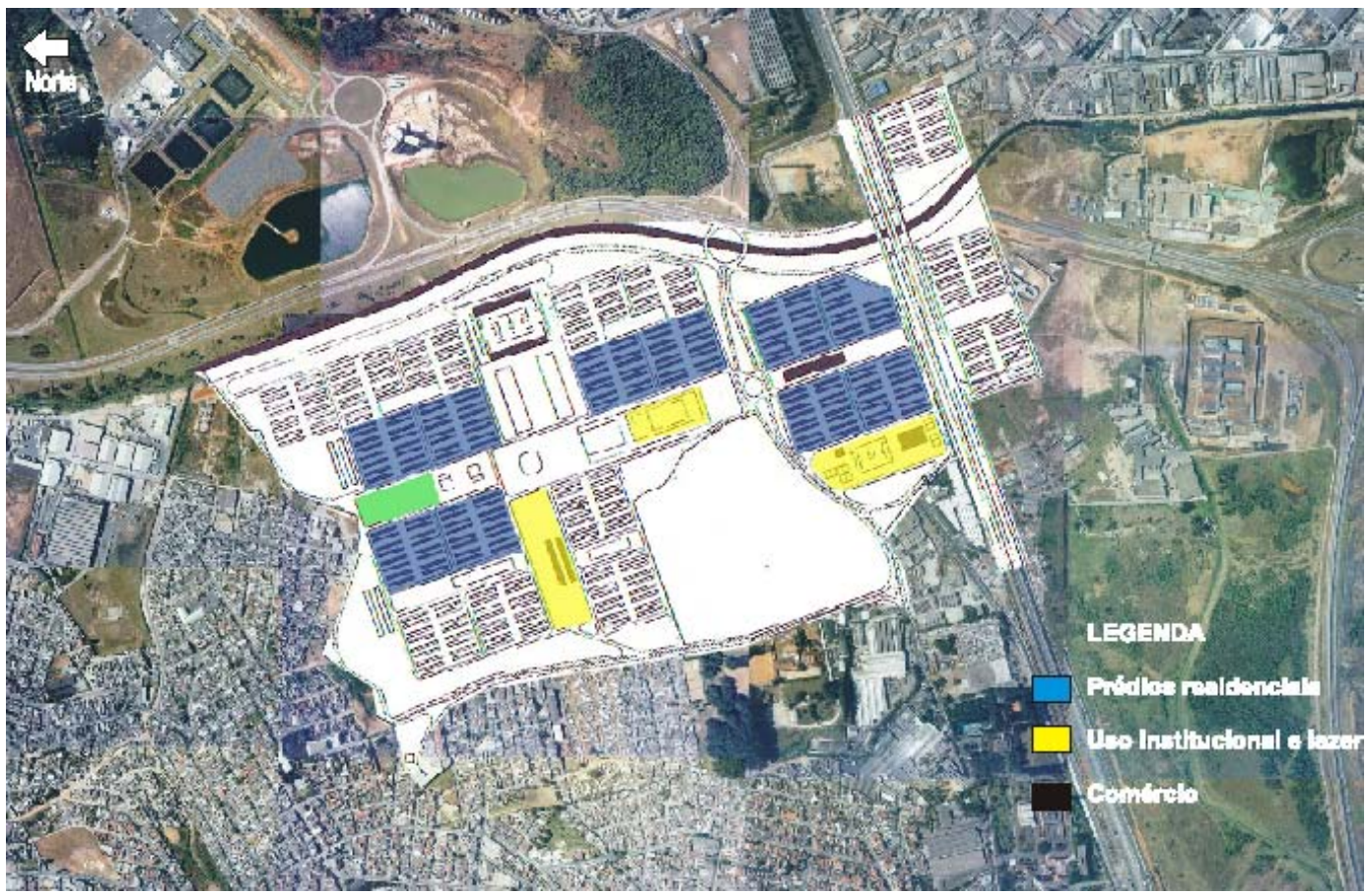

Figura 90 - Implantação do Conj unto Habitacional Zezinho Magalhães Prado/Parque CECAP com destaque no que foi construído.

Fonte: Solimar Mendes Issac.

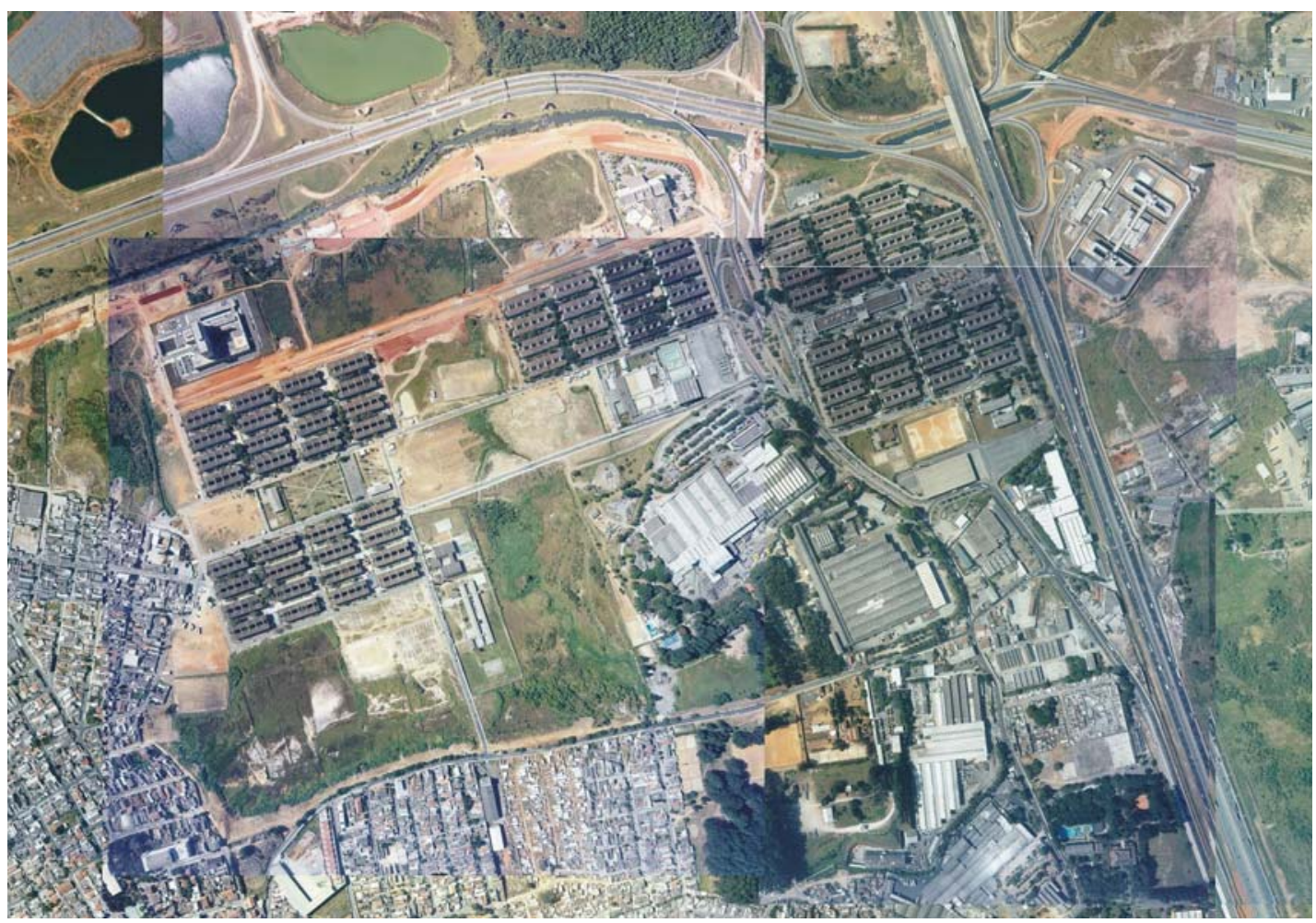

Figura 90 - Implantação do Conj. Hab. Z. M. Prado em foto aérea 2007..

Fonte: Solimar Mendes Issac. 
Acho que você precisa ver isso. A frase está ruim. No bairro CECAP residem hoje aproximadamente $81 \%$ desta população são proprietárias do imóvel, $99,93 \%$ do lixo é coletado, os mesmo 99,93\%tem esgoto ligado à rede coletora da cidade, $98,77 \%$ das residências do bairro possuem água tratada pela companhia local e a taxa de urbanização da área é de 100\% (ISSCAC, 2007).

Dos 22 grupos de oito blocos inicialmente propostos, foram construídos 10 desses grupos, sendo que nove grupos têm oito blocos e um grupo tem seis blocos, ou seja, menos de 50\% do total previsto foi implantado.

Com quase 40 anos da sua concepção de projeto, as transformações principalmente em relação aos conceitos que o simbolizavam na época, são marcantes, apesar das intervenções que desconheceram as idéias originais. Os espaços coletivos que eram integrados em sua totalidade, hoje esbarram em cercas de condomínios fechados. Como decorrências, os equipamentos coletivos que serviriam para todo o conjunto, em parte se encontram dentro desses condomínios.

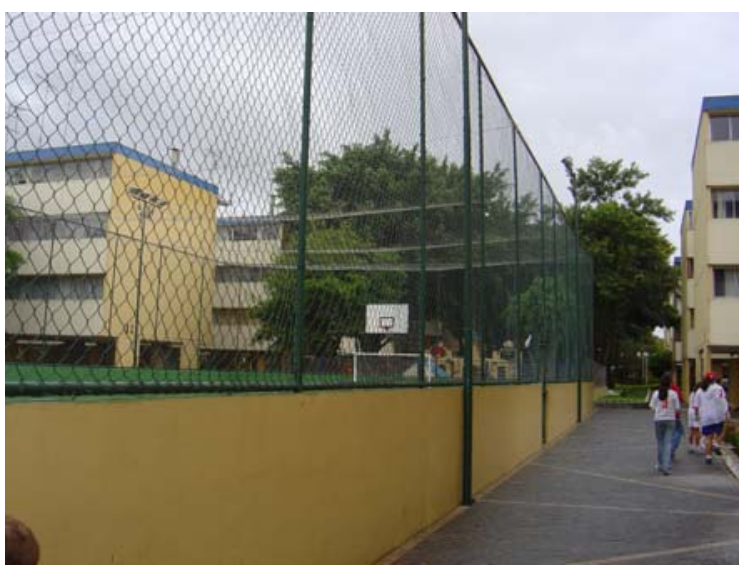

Figura 91 - Quadra entre blocos Fonte: Fabiana Cerávolo.

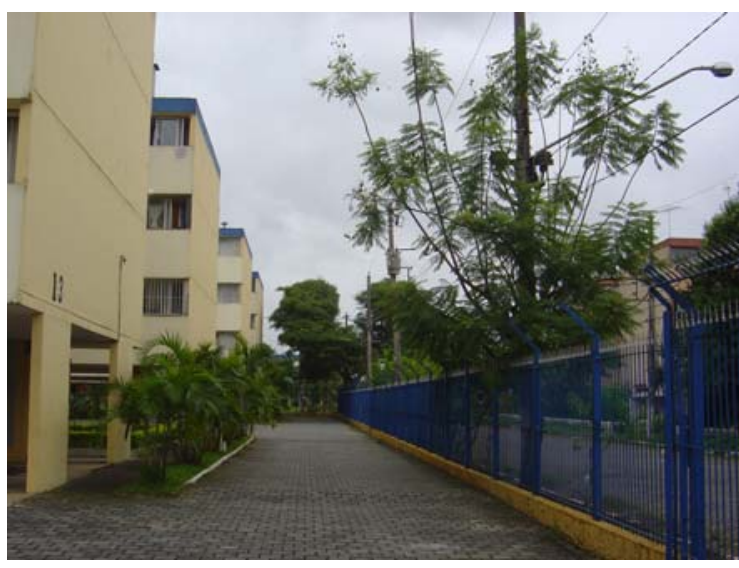

Figura 92 - Cerca muito próxima dos blocos. Fonte: Fabiana Cerávolo. 


\title{
CAPÍTULO 4 \\ Considerações Finais
}

\begin{abstract}
“(...) eu comentava agora pouco aqui com o Mário, a respeito de uma especificação de fechaduras, que nenhuma empresa brasileira passava, então, a La Fonte na época que era a top e ainda é, não atendia as especificações da CECAP, e o Bauer desenvolver uma maquininha que controlava, acionava as fechaduras dos trincos, e a especificação exigia que as fechaduras resistissem a 100.000 acionamentos, nenhuma ultrapassava 45.000/47.000 acionamentos, inclusive a La Fonte, e nessa ocasião, abriu-se o mecanismo e verificou-se que tinham alguns elementos, especialmente um que acionava a lingüeta, que era em "desamaqui" , então a proposta foi fundir no lugar do "desamaqui" em bronze e aí foi pra 140.000 acionamentos, e a La Fonte passou a incorporar na linha dela a inovação, que foi um avanço tecnológico ditado pela obra. Então veja que estava na frente." 1
\end{abstract}

Este pequeno trecho da entrevista do engenheiro Fernando Gonçalves foi escolhido, pois é revelador dos ideais dos profissionais modernos, arquitetos ou engenheiros e do papel deles para o desenvolvimento industrial do país. 0 objeto, a fechadura, poderia ser outro mais expressivo na obra (formas metálicas da terceira etapa, utilizadas nas fundações, os caixilhos desenvolvidos também para a terceira etapa), mas a fechadura e sua função possuem um simbolismo emblemático de abertura, não apenas das portas das unidades habitacionais, mas figurado das "portas" do pensamento, para auxiliar a esclarecer os termos do debate naquele período e a sua importância atual.

O trecho da entrevista revela, talvez o óbvio, que há um lugar e um papel do trabalho profissional, digamos técnico-científico, no desenvolvimento da tecnologia da construção, nos termos apresentados na

\footnotetext{
${ }^{1}$ Entrevista de Fernando Gonçalves cedida a autora no dia 05/ 04/ 2007.
} 
Introdução do trabalho. E mais, que esse trabalho é passível de ser bem sucedido, no caso, as fechaduras foram alteradas e a indústria incorporou a inovação.

Esse episódio é esclarecedor da postura de Artigas, autor do projeto do Conjunto Habitacional Zezinho Magalhães Prado, ou seja, o papel dos arquitetos (e dos engenheiros, ainda que Artigas não formulasse nestes termos) seria o de auxiliar o desenvolvimento nacional no campo específico de trabalho, o da construção civil. Assim, no discurso Aos Formandos da FAUUSP, de 1955, já definia:

“(...) o caráter inovador de nossa arquitetura não pode ser apreciado isoladamente, nos limites do fato arquitetônico. É o resultado de todos os esforços feitos no sentido do avanço no domínio da técnica e da ciência." 2

0 trecho também revela que para as inovações propostas pelos profissionais serem implantadas, elas necessitam de viabilidade econômica. Assim, a empresa, aparentemente sem ter tido gasto no desenvolvimento de seu produto, atendeu a especificação porque introduziu a inovação na produção do produto para o mercado em geral. Novamente parece óbvio, mas ela o fez porque era economicamente e comercialmente viável.

A pergunta é, porque diante de tantas inovações propostas que caminhavam no sentido da industrialização da construção, porque apenas algumas foram introduzidas, e, mesmo assim, parte delas na terceira fase?

Se tomarmos como referência a questão central, os elementos préfabricados de concreto que tiveram de ser substituídos por alvenaria tradicional, as interpretações dos fatos é reveladora.

\footnotetext{
2. Artigas, J. B. V., Caminho da Arquitetura, Aos Formandos da FAUUSP, de 1955 p. 19.
} 
Para Fábio Penteado, como visto, mas é importante retomar, o Conjunto:

“(...) foi pensado pré-moldado inteiro, mas também por uma fantasia ou poesia, foi feito o projeto, calculado todo para pré-moldado, custou uma fortuna o contrato do projeto de estrutura pré-moldada. É mesma coisa, primeiro, não fazia parte e ainda hoje não faz parte da cultura, na época que a gente construiu. Segundo, se você faz uma usina e faz aquela obra CECAP, aí joga fora a usina, porque não teria outra pra fazer, o custo disso era tão grande que não foi, a única coisa prémoldada lá foram feitas as escadas e alguns componentes." 3

Já para Gisela Visconti:

"O projeto foi desenvolvido para 10.560 unidades habitacionais. Tendo em vista o número de habitações, distribuídas em edifícios todos iguais, a estrutura foi calculada em concreto pré-moldado, o que representaria uma economia significativa no consumo total de concreto e também uma redução no prazo de execução da obra. Entretanto, quando da apresentação do projeto ao Banco Nacional da Habitação - BNH, para liberação de financiamento, foi aprovada a construção de somente 480 unidades na primeira etapa. Esta decisão inviabilizou a execução da estrutura de concreto pré-moldado, tendo sido recalculada a estrutura para construção por processo convencional." 4

\footnotetext{
${ }^{3}$ Texto de Fábio Penteado (200?) - anxo 6.

${ }^{4}$ Texto Conj unto Habitacional Zezinho Magalhães Prado, Maria Giselda Visconti. Ver anexos.
} 
Ou seja, a duas visões, a de Penteado, que sem explicitar exatamente, mas agregando o problema do fluxo de demanda, coloca a questão em termos de fantasia. E a de Visconti, para quem o problema seria o $\mathrm{BNH}$, que com a sua política populista de emprego, inibia o desenvolvimento da indústria da construção.

Acreditamos que os dois entendimentos estão corretos, entretanto, não são suficientes para a compreensão da questão. Evidentemente, sem querer resolver a questão de forma definitiva, diríamos que na construção civil brasileira, o sistema construtivo é misto, caracterizado por um processo tradicional racionalizado, pois expressa e incorpora os mecanismos sociais que articulam elementos modernos (industriais) e arcaicos (tradicionais). Esses elementos vão de materiais, equipamentos, produtos, técnica construtiva, qualificação da mão-de-obra, relações de trabalho, remuneração da mão de obra, etc. Tal sistema é estranhamente inovador e conservador ao mesmo tempo, mas é muito arraigado nos resultados que se mostram lucrativos e com pouco risco econômico, justamente, porque os elementos arcaicos do sistema, que podem ser representados pela mão-de-obra, pela técnica construtiva, enfim, por qualquer dos seus componentes, são vistos como, e de fato devem ser, garantia de lucratividade.

Há certamente uma explicação mais abrangente para esta condição, e ela foi fornecida por Francisco de Oliveira, para quem o capitalismo no Brasil se desenvolveu, e ainda se desenvolve, associando os elementos arcaicos e modernos (OLIVEIRA, 1988) ${ }^{5}$. Isto é fundamental, pois a solução desta condição extrapola o quadro profissional e mesmo da construção civil. Mas também e, sobretudo, por ser um processo em desenvolvimento, tal condição propicia que novas "portas" sejam abertas e, para tanto, os arquitetos e os engenheiros, devem pesquisar novas "fechaduras", com o risco de não serem viáveis, mas com a possibilidade de serem incorporadas e, independente, da

\footnotetext{
${ }^{5}$ OLIVEIRA, Francisco de - ?A Economia Brasileira: Crítica à Razão Dualista,? .
} 
lucratividade privada da empresa, podem redundar em ganhos sociais, como 0 conjunto permitiu para os seus moradores e mesmo para a sociedade.

Cabe, por fim, algumas considerações sobre o Conjunto do ponto de vista de equipamento urbano e social. Ele hoje se destaca positivamente na paisagem, apesar de sua regularidade formal. As unidades visitadas encontram-se em bom estado de conservação. 0 seu sucesso, em termos de qualidade construtiva e de habitabilidade, tornou a venda de suas unidades atraentes e boa parte da população inicial não se encontra mais lá. As freguesias assumiram, de fato, o status de condomínio, e na lógica urbana atual todos foram cercados, impedindo o livre acesso e gerando áreas residuais entre eles, que não se estruturam como locais de convívio.

Uma questão sempre citada é a dos pilotis. Na arquitetura moderna, a idéia clássica é a de possibilitar o livre trânsito ao rés do chão, propiciando convívio e lazer. Na prática, nesse e em outros conjuntos, o espaço foi transformado em garagem. Há duas formas de ver a questão. A primeira é que indica o declínio da sociabilidade e o aumento do individualismo, a segunda, que não desconsidera a primeira, busca incorporar a "questão garagem nos projetos", como um item a ser resolvido. Para Penteado, havia poucas vagas previstas de estacionamento, porque o automóvel estava fora dos itens de projeto, "quem iria imaginar que o operário lá ia ter automóvel." ${ }^{6}$ Com 0 aumento da possibilidade de aquisição desse bem os moradores resolveram a situação de forma imediata.

Enfim, há "portas" ou problemas mais nobres do que outros, mas eles sempre existirão e sempre solicitarão soluções.

\footnotetext{
${ }^{6}$ Entrevista de Fábio Penteado cedida a autora no dia 09/ 03/ 2007.
} 
ALMEIDA, P.C. (1971). Industrialização da Construção. EESC - USP. Departamento de Arquitetura e Planejamento. Relatório à FAPESP.

ANDRADE, C. M.; BONDUKI, N. G.; ROSSETO, R. (1993). Arquitetura e Habitação Social em São Paulo: 1898/1992. São Paulo.

ARGAN, G. C. (1992). A Arquitetura dos Engenheiros. In: ARGAN, G. C. (1992). Arte Moderna. Editora Companhia da Letras. São Paulo.

ARÍS, Carlos Marti (1991). Las formas de la residência em la ciudad moderna - Vivienda y Ciudad em lá Europa de entreguerras. Servicio de Publicaciones de la UPC, Barcelona. Pg. 13-48.

AYMONINO, C. (1973). La vivienda racional - ponencias de los congresos CIAM 1929-1930. Editorial G. Gili. Barcelona, Espanha.

BARON, C. M. P. (1999). Introdução à História da Tecnologia de Conjuntos Habitacionais. Dissertação (metrado) EESC-USP. São Carlos, São Paulo.

BENÉVOLO, L. (1989). História da Arquitetura Moderna. Ed. Perspectiva. São Paulo.

BOHE, W. M. (1969). Manual de la Construccion con Piezas Prefabricadas.3.ed.1.v, Editora Blume, 1969

BONDUKI, N. G. (1998). Origens da habitação social no Brasil: arquitetura moderna, lei do inquilinato e difusão da casa própria. Estação Liberdade. São Paulo.

BONDUKI, N. G. (2001). Habitação econômica e arquitetura moderna no Brasil (1930-1964). Relatório de pesquisa programa de bolsas produtividade em pesquisa CNPq, referente ao período de julho de 1999 a junho de 2001. São Carlos, São Paulo. 
BONDUKI, N. G.; KOURY, A.P.; MANOEL, S. (2003). Análise tipológica da produção de habitação econômica no Brasil (1930-1964). In: Anais do Docomomo, São Carlos, São Paulo.

BRUNA, P. J. V. (1976). Arquitetura, Industrialização e Desenvolvimento. Ed. Perspectiva. São Paulo.

BUZZAR, M. A. (1996). João Batista Vilanova Artigas: elementos para a compreensão de um caminho da arquitetura brasileira, 1938-1967. Tese (mestrado) Faculdade de Arquitetura e Urbanismo / FAU. São Paulo.

CARPINTÉRO, M. V. T (1997). Os Engenheiros -arquitetos e a formulação da política Habitacional no Brasil (São Paulo 1917-1940). Editora da Universidade de Campinas/ UNICAMP. Campinas, São Paulo.

CHAVES, M. (1986). A indústria da construção no Brasil: Desenvolvimento, estrutura e dinâmica. Dissertação (mestrado), Instituto de Economia Industrial, UFRJ. Rio de J aneiro.

DREYSSE, D. W. (1988). Les Cites de Ernest May - Guide d'architecture des cites nouvelles de Francfort (1926-1930). Editora Dieter Fricke $\mathrm{GmbH}$ and Escole d'architecture de Strasbourg. Frankfurt am Main and Strasbourg. Alemanha e França.

ENGELS, F. (1988). A questão da habitação. Acadêmica (Coleção clássicos das ciências sociais). São Paulo.

FARAH, M. F. S. (1983). Estado, Previdência Social e Habitação. Dissertação (mestrado) - FFLCH, USP, São Paulo.

FARAH, M. F. S. (1992). Tecnologia, Processo de Trabalho e Construção Habitacional. Tese (doutorado) - FFLCH, USP, São Paulo.

FERRO, S. (1982). Canteiro e o desenho . Proj eto Editores. São Paulo.

FICHER, S. (1972). Subsídios para um Estudo do Conjunto Habitacional Zezinho Magalhães Prado. Monografia de conclusão de curso (TCC). FAU-USP. 
FICHER, S.; ACAYABA, M. M. (1982). Arquitetura Moderna Brasileira. Projeto Editores Associados Ltda. São Paulo.

FRAMPTON, K. (1997). História Crítica da Arquitetura Moderna. Editora Martins Fontes. São Paulo.

FRASSON, A. S. (2000). Habitação social e arquitetura moderna: a apropriação dos conjuntos residenciais dos IAPs (1940-2000). Dissertação (Mestrado) EESC-USP. São Carlos, São Paulo.

FREITAS, M. L. (2002). Os periódicos de Engenharia e o Debate de Arquitetura e da Racionalização das Construções em São Paulo 1915-1937; Relatório de Iniciação Científica. SAP- EESC-USP. São Carlos, São Paulo.

GAMA, R. (1986). Tecnologia e o Trabalho na História. EDUSP. São Paulo.

GAMA, R. (org. ) (1982). Glossário. FAUUSP. São Paulo.

GAMA, R. (org. ) (1985). História da Técnica e da Tecnologia: Textos Básicos. EDUSP. São Paulo.

GITAHY, M. L. C.; PEREIRA, P. C. X. (org.) (2002). 0 complexo industrial da habitação econômica moderna, 1930-1964. Editora RiMa. São Carlos, São Paulo.

GROPIUS, W. (1972). Bauhaus: Nova Arquitetura. Ed. Perspectiva. São Paulo. IAPI - Instituto de Aposentadoria e Pensão dos Industriários (1950). O Seguro Social a Indústria Brasileira o Instituto dos Industriários. Relatório-estudo do Engenheiro Alim Pedro, presidente do IAPI. Rio de J aneiro.

ISSAC, S.M. (2007). Parque CECAP Guarulhos: transformação urbana.. Dissertação (mestrado) - FAU, USP, São Paulo.

KOPP, A. (1990). Quando o moderno não era um estilo e sim uma causa. Nobel. São Paulo.

KOPP, A. (1991). Quando o moderno não era um estilo e sim uma causa. Nobel. São Paulo. 
KOWARICK, L. F. F. (Org) (1988). Lutas Sociais e a Cidade São Paulo: Passado e Presente. Paz e Terra. Rio de J aneiro.

LAMPARELLI, C. M. (1982). A habitação e a industrialização das construções. Espaço e Debates.

Le CORBUSIER (1993). A carta de Atenas. EDUSP. São Paulo.

Le CORBUSIER (1994). Por Uma Arquitetura. Editora Perspectiva. São Paulo.

LEME, M. C. S. (coord.) (1999). Urbanismo no Brasil: 1895-1965. Estúdio Nobel, FUPAM, FAU USP. São Paulo.

LOPES, L. C. (1996). Brasília: o enigma da Esfinge a Construção e os Bastidores do Poder. Editora da Universidade do Vale do Rio dos Sinos. São Leopoldo, Rio Grande do Sul.

MANOEL, S. K. (2003). Fundação da Casa Popular (1946-1964): Projeto frustrado de construção de uma política habitacional. Relatório de qualificação. SAP/ EESC/ USP, São Carlos, São Paulo.

MARICATO, E. (1984). Indústria da construção e política habitacional. São Paulo: S.N. Tese (doutorado) - FAU- USP. São Paulo.

MARICATO, E. (1995). Habitação e as políticas fundiária urbana e ambiental. Rio J aneiro.

MARICATO, E. (Org) (1979). A Produção capitalista da casa (e da cidade) no Brasil industrial. São Paulo: Editora Alfa-Omega.

MARTINS, C. A. F. (1992). Razon, Ciudad y Naturaleza: La génesis de los conceptos en el urbanismo de Le Corbusier. Tese (doutorado) Departamento de Estética y Composición - Esuela Técnica Superior de Arquitetura de Madrid. Madrid, Espanha.

MARTUCCI, R. (1990). Projeto tecnológico para edificações habitacionais: Utopia ou desafio? Tese (doutorado) FAU-USP. São Paulo. 
MASCARÓ, J. L. (Coord.) (1975). Análise Macroeconômica da Construção de Edifícios como Fator de Desenvolvimento Nacional. EDUSP. São Paulo.

MASCARÓ, L. (1990). Arquitetura e Tecnologia. Nobel. São Paulo.

MONTENEGRO FILHO, R.A. de L. (2007). Pré-fabricação e a obra de Eduardo Kneese de Mello. Dissertação (mestrado) - FAU, USP, São Paulo.

MOTOYAMA, S. (org.) (1994). Tecnologia e Industrialização no Brasil: Uma Perspectiva Histórica. Ed. UNESP/ CEETEPS. São Paulo.

OlIVEIRA, F. (1979). A Economia Brasileira: Crítica da Razão Dualista. In: Novos Estudos 2, CEBRAP. São Paulo.

OLIVEIRA, Francisco de (1988). A Economia Brasileira: Crítica à Razão Dualista. Petrópolis. Vozes.

OSEKI, J . H (1982). Algumas tendências da construção civil no Brasil. EDUSP. São Paulo.

OSEKI, J . H (1983). Arquitetura em Construção. Dissertação (mestrado) FAUUSP. São Paulo.

PAWLEY, M. (1977). Arquitetura versus vivienda de massas. Ed. Blume. Barcelona, Espanha.

PEVSNER, N. (1958). Pioneiros del Deseño Moderno de William Morris a Walter Gropius. Ediciones Infinito. Buenos Aires.

POZZI, M.P.C. (1985). Papel da Tecnologia na Produção de Habitação Popular. Estudo de caso: Conjunto Habitacional J osé Bonifácio. Dissertação (mestrado) - EESC, USP, São Paulo.

POZZI, M.P.C. (1999). A Explosão do Autofinanciamento na produção da moradia em São Paulo nos anos 90. Tese (doutorado) - FAU, USP, São Paulo. REVISTA DESENHO. São Paulo: Laboratório de Artes Gráficas da FAUUSP. ㄲo 04. maio de 1972. 
ROLNIK, Raquel (2003). A cidade e a lei: legislação, política urbana e territórios na cidade de São Paulo. São Paulo. Studio Nobel: FAPESP.

ROLNIK, Raquel (s.d.). Cada um no seu lugar (São Paulo, início da industrialização: geografia do poder). Dissertação de mestrado apresentada a FAU/ USP. P.

ROSSO, T. (1979). Racionalização das Construções. FAU-USP. São Paulo.

SABATTINI, F. H. (1989). Desenvolvimento de Métodos, Processos e Sistemas Construtivos - Formulação e aplicação de uma metodologia. Tese (doutorado) Escola Politécnica/ USP. São Paulo.

SEGAWA, H. (1999). Arquiteturas no Brasil: 1900-1990. EDUSP, São Paulo.

SHOROEDER, R. (1977). Proposta de Industrialização Habitacional ganha prêmio Brasilit / proj. Eduardo de J esus Rodrigues, colab. Marlene Yurgel e Lúcio Gomes Machado. A Construção São Paulo (1977): 9-11, 30-12-1985.

VALENTIM, J.; A união da racionalização com a estética; pré-fabricados arquitetônicos. Construção São Paulo, n.2286, p. 27-8, 02-12-1991.

VARGAS, M. (org.) (1995). História da Técnica e da Tecnologia no Brasil. UNESP/ CEETPS. São Paulo.

XAVIER, A.; LEMOS, C.; CORONA, E. (1983). Arquitetura Moderna Paulistana. Pini. São Paulo. 
Estão em anexo os seguintes documentos listados abaixo:

DESCRIÇÃO

ANEXO 1 - Entrevista Fábio Penteado

ANEXO 2 - Entrevista Giselda Visconti

ANEXO 3 - Entrevista Geraldo Vespasiano Puntoni

ANEXO 4 - Entrevista Fernando Gonçalves

ANEXO 5 - Entrevista Mário Savioli

ANEXO 6 - Texto Fábio Penteado/Giselda Visconti

ANEXO 7 - Documentação Fotográfica

ANEXO 8 - Plantas
PÁGINA

II

$X X V$

XXIX

XXXIV

XLVII

LIII

LVIII

LXV 
Entrevista com o arquiteto Fábio Penteado, realizada dia 09/03/2007, no escritório do arquiteto, com início às 10 h30 da manhã. Entrevista realizada por mim, contando apenas com a presença de nós dois.

Fábio: Isso aqui é o que nunca vai aparecer na história, que é o começo...CECAP, caixa para o povo, isso teria sido criado, não sei o nome, não sei a época, mas quando o Zezinho Magalhães Prado entrou e assumiu essa chamada CECAP, ela tinha feito doze ou quatorze, umas dez casas, por aí. Então eu fiz esse texto, pra alguma coisa que não me lembro, mas muito claro que isso aqui é verdade, na minha opinião... “em 66, no momento da posse do governador de São Paulo Abreu Sodré, do jeito que a tradicional festa de distribuição de cargos públicos, entre os agregados políticos e afins, quando o novo Governador, nomeado pelo Governo Militar se deu conta que havia esquecido entre os beneficiados seu velho amigo, Zezinho Magalhães Prado, ex-prefeito e ex-presidente do Clube de Futebol XV de J aú". ' A CECAP era uma coisa inexistente, quando o Abreu Sodré foi nomeado governador, fez a festa pros amigos e esqueceu do Zezinho, então ele perguntou, o que que sobrou aí? Tinha a CECAP, essa foi à história. Eu sei que foi assim, mas nunca ninguém vai dizer que foi assim, eu que digo. O Zezinho era um homem muito interessante, o que que ele fez, ele se apropriou para a CECAP de um terreno muito grande, que tinha uma história complicada, que tava na mão da Caixa Econômica Estadual em Guarulhos, esse terreno tinha passado pelas mãos do J osias Paes de Barros, era estrada de ferro Sorocabana, era proprietário. Como o terreno também não valia nada, ele tava cheio d'água, deram 0 terreno para o Zezinho. O Zezinho tinha um irmão, que eu não me lembro o nome agora, que era um arquiteto, ou estudante de arquitetura, que orientou o Zezinho com um grupo de amigos, sendo que este irmão dele tinha

\footnotetext{
${ }^{1}$ Ver texto na íntegra no anexo 7.
} 
participado de ações políticas do partido comunista, e que o Zezinho acabou finalmente montando um projeto quase que fantástico, entre a época anterior a CECAP, e o que aconteceu depois da CECAP em termos de habitação popular, é quase um retrato do Brasil como um todo. Na minha opinião, é como se tivesse mudado a escala de se ver o Brasil. De 1/ 100, passou a 1/ 10. O Brasil não existia... as capacidades do país não eram entendidas, nem conhecidas, nem reconhecidas. Depois um Conjunto Habitacional de 2.000 unidades era algo que ninguém imaginava ser possível, como se fosse loucura, tanto é que eu mesmo quando fui levar o projeto para apresentar no BNH a diretoria se recusou a vê-lo, por achar que aquilo era fantasia. E o Zezinho continuou com o Artigas, outra ousadia muito grande. O Artigas tinha... ele tava pendurado ainda em um processo da justiça militar, mas era muito complicado. Ele só aceitou se eu estivesse junto com ele... eu disse vc tá louco! Eu tinha sido eleito presidente do Instituto de Arquitetos, também de uma forma um pouco complicada, tinha sido eleito praticamente pelos arquitetos de todo Brasil contra os arquitetos de São Paulo e Rio de Janeiro, porque o grupo era um grupo muito radical, esquerda. Essa foi a origem do Zezinho Magalhães Prado, que recebeu um organismo governamental curioso, que era a antiga CECAP, os dados corretos eu não sei, eu sei que ou em 16 anos fez 14 casas, ou em 14 anos fez 16 casas. O que acontece... um detalhe curioso também, havia uma contestação violenta de alguns arquitetos poderosos, em São Paulo, que insistiam de qualquer forma que eu e o Artigas, de nos tirar do processo, inclusive com atitudes públicas. Eu me lembro, por exemplo, evitar certas coisas, eu fiz um contrato de trabalho do Artigas e o meu, que seja subordinado ao tribunal de contas do Estado, que era um salário tão pequeno que equivalia a de um projetista, eu nem consultei o Artigas, ele nem perguntava, se alguém nos tirar daqui vai ter que fazer contrato equivalente. Eu, quando conversei com o Oscar Neimeyer ele disse, isso é que é bonito, é o cacete, é muito ruim, mas é a coisa que nós fizemos. Que havia uma tentativa de nos tirar de qualquer jeito pelo pessoal, o IAB 
tinha ainda essa questão de grupo de direita, grupo que tinha participado quase que oficialmente do golpe militar.

\section{Fabiana: E porque que era tão importante esse projeto? Por que era importante ficar nesse projeto?}

Fábio: Ficar, não sei se era importante ficar. Se foi assumido e houve um convite, um trabalho que nunca tinha sido feito igual no Brasil, é lógico que tinha interesse.

\section{Fabiana: A oposição também tinha interesse?}

Fábio: Tinha interesse primeiro em nos tirar, não nos dar a glória. Isso dava uma força enorme em todo pensamento de arquitetura, em termos de ponto de vista. Aí é questão de tudo junto, né. Mas isso foi assim que começou, as pessoas que participavam inicialmente eram muitos arquitetos do serviço público, principalmente o Geraldo Puntoni, o Ruy Gama, a Giselda Visconti, que acabou ficando a minha diretora do escritório, e eu e o Artigas propusemos fazermos um escritório de projetos, o escritório da CECAP e nós como arquitetos autônomos, éramos diretores do escritório. Esse escritório foi ampliado depois com a vinda do Paulo Mendes da Rocha e foram chamados outros arquitetos para formar o grupo de trabalho, Arnaldo Martino, e pouco a pouco aumentou muito o número, Renato Nunes, e foi montado o escritório. Ao mesmo tempo, era um trabalho de um tamanho que nunca ninguém tinha visto nesse período, que o Brasil era fechado de uma forma pequena. Nessa época, que foi uma iniciativa minha, direta, mas com o apoio do Instituto, nós contávamos com a posição do ministro do planejamento, que era o Roberto Campos, uma coisa fantástica. Ele impunha ao CREA o direito de trabalho no Brasil de todos os engenheiros e arquitetos norte-americanos, veja bem, isso foi derrubado numa reunião... mas já tinham derrubado o ministro em um encontro em Curitiba. Aonde eu perguntei, porque o ministro toma uma 
atitude dessa? Trata-se de grandes recursos vindo de bancos internacionais para obras no Brasil, e os bancos exigem participação na responsabilidade do projeto. Aí eu perguntei, qual o valor envolvido? Era U\$40.000.000. Logo depois o Quércia roubava isso por mês em Campinas. Rouba-se isso normalmente no Brasil em qualquer iniciativa. Esse escritório foi se formando, mas foram sendo contratados técnicos para cada setor de atividade. Alguns projetos como, por exemplo, o de estrutura de concreto armado, do escritório Figueiredo Ferraz, contrato que eu assinei, eles tiveram um trabalho infernal porque nunca ninguém tinha feito um contrato do porte daquele, pagando oficialmente a repetição de projeto, coisa que não era muito comum. $E$ passava pelo tribunal de contas, cada contrato era um trabalho burocrático e garantia que fosse efetivado. Então foram contratadas equipes de todos os tipos. A apresentação do proj eto no Rio de J aneiro, no BNH, já tinha morrido o Zezinho Magalhães, era o irmão dele que ficou de levar o projeto lá, na primeira reunião não houve interesse nem de ver o projeto. Com dificuldade um diretor admitiu ouvir, quando eu comecei a exposição detalhada, ele concordou de chamar alguns outros, começou a ver algum interesse, porque era tido como fantasia. Por exemplo, no levantamento feito pelo governo Roberto Campos, havia uma proposta de Lei, e esta que nós modificávamos na reunião em Curitiba, que todo município teria que ter um plano diretor no prazo de tantos anos, sendo que ele não receberia um benefício federal. Esse benefício, isso deveria ser ensinado nas escolas, havia uma distribuição eqüitativa de todos os municípios brasileiros de um fundo do imposto de renda do país, o que dava vamos dizer na época, 100.000 reais, sei lá, indistintamente, esse dinheiro era entregue. Até esse momento que foi 0 encontro de Curitiba, que foi montado pelo IAB quando eu assumi a presidência. Nós colocávamos em discussão, o que interessou ao ministro, quantos municípios tinha o Brasil, o que era o plano diretor e quanto custa o plano diretor, dentro daquela idéia assumida pelo governo, todo dinheiro que foi não daria, ninguém sabia nem quantos municípios tinha. Um levantamento feito através do IBGE, apareceram oitocentos e poucos municípios fantasmas, 
mas registrados, deputado, senador, desembargador, que com procuração recebia essa verba que era entregue no Rio de Janeiro e gastavam nas boates do Rio. Depois desse encontro do IAB que foram levantados quantos municípios tinham mais de 50.000 habitantes, tinham 22. Quer dizer, isso a 40 anos atrás, em 1966. Então uma cidade de 60.000 habitantes na verdade era, reconhecidamente eram 22, agora os recursos para o desenvolvimento tinham pra todo mundo, tínhamos que estabelecer prioridades, que foi nessa reunião que eu conduzi, pela primeira vez no Brasil se estabeleceu uma discussão de prioridades de coisas que ninguém nunca tinham discutido. Prioridade para desenvolvimento urbano de cidades com potencial de desenvolvimento, mas esse potencial nunca tinha sido colocado dessa forma nem publicado, processo de desenvolvimento industrial, mas também ligado a patrimônio histórico, meio ambiente. Nunca tinha se discutido essa palavra meio ambiente, isso foi um trabalho do IAB, aquilo que o IAB sempre aprendeu da Europa, da época, que era a União Internacional de Arquitetos, era uma cultura de conhecimentos que deu ao IAB essa possibilidade de atuação.

\section{Fabiana: Como que veio a idéia de freguesia?}

Fábio: Era uma bobagem, essa acho que foi do Ruy Gama, o Ruy Gama tinha ganhado uma bolsa em Portugal, passou lá um ano, tava muito influenciado, também acho que a família dele é de Portugal. A palavra freguesia pode ter alguma relação, é uma coisa simpática, mas saiu da cabeça dele. Foi facultada no projeto, ta lá a viva a cidade e não tem nenhum valor freguesia. Não é coisa que pega. Então é dessa maneira que as coisas foram acontecendo, e foi feito aí, de maneira muito apressada porque o prazo era muito curto e ninguém tinha feito um projeto desse porte, ninguém! Foi improvisado o projeto, na minha opinião, colocando claro que quando eu assumi o trabalho na CECAP, eu fui o Coordenador Geral total de tudo que é chato. Assumir os contratos, brigar com as oposições, ganhar o direito de deixar as verbas disponíveis na mesa para fazer os projetos. O Artigas 
participou muito pouco dessa parte do projeto, eu diria quase nada. 0 trabalho foi andando. Na minha opinião inicial, a proposta de uma coisa muito nova mereceria uma discussão muito ampla, o que não houve nem tempo para acontecer, mas eu acho que tem um ponto que deve ser muito.... a proposta da CECAP, ela foi colocada no papel um pouco assim, um pouco etérea, como se fosse uma cidade nova em qualquer lugar do planeta, desligada de tudo, como se ele tivesse que ter uma auto-suficiência para ser um dia uma cidade, que acabo nem sendo porque foram construídos 4.000, 5.000 unidades. Enquanto na minha cabeça, porque eu não tinha experiência pra brigar por isso, e na época nem tinha condições, era hora nada mais nada menos do que uma extensão da extensão de Guarulhos. Teve um erro que eu cometi, reunindo no palácio do governador, todos os secretários de estado, e cada um podia interferir em cada setor, ensino, abastecimento, quando na verdade aquilo era uma extensão da cidade de Guarulhos. Como está comprovado, a cidade de Guarulhos acabava no CECAP, depois era uma área militar, não tinha o campo de aviação de Guarulhos, não existia, era uma base militar. Então, eu acho que isso é uma coisa pra analisar com muita atenção, o terreno da CECAP foi ocupado em parte, e o que sobrou tem grande dificuldade de utilizá-lo. Na minha opinião, que é uma opinião crítica, é muito parecido com a Cidade Universitária, que eu também participei dessa reformulação dessa Cidade Universitária, eram vários arquitetos, pouco antes da CECAP. Também foi um projeto improvisado, numa área espetacular, uma área verde, São Paulo tem uma ou duas iguais, foram edifícios isolados, com problema de integração, resultando também ruas separadas dos edifícios com calçadas muito largas, porque os jardins custam caro. Cada bloco de edifício, cada um tem sua biblioteca, sua cozinha, seu auditório, todos pobres e falta àquela base que seria a base de uma Universidade, e eu fiquei de mãos atadas. 0 que aconteceu no Cumbica é de difícil utilização, nem mesmo para reposição de freguesias iguais, nem pra isso, mais ainda, lamentável ainda, a CECAP, depois CDHU, nunca se preocupou de dar a essa área de terreno condições de legalidade, nesses últimos 20 anos eu tive pelo menos mais de 
dez vezes no CDHU, tentando utilizar o meu direito autoral, porque o contrato é Artigas e ou eu. Nunca foi atendido, a última vez que eu fui eles buscavam um contrato comigo até pra definir as áreas que sobraram, definir, botar numa condição de fazer parte do cadastro municipal, ou até mesmo pra aprovar um projeto que dê destino. Claro que hoje em dia ainda é um paradigma em projeto de habitação, foram tentadas o quanto de disponível de técnicas aprimoradas, vou te contar algumas que não estão nos relatórios, porque eu pessoalmente estudei uma adaptação de equipamentos domésticos, nem sei que nome tem. Eu fiz uma coisa engraçada, uma é época o governo do Brasil resolveu participar de um encontro em Caracas, não é conforto doméstico. E aí lembraram que a CECAP tinha feito uma proposta e pediram pra CECAP fazer uma tese que foi levada a Caracas, feito com a Doutora Giselda Visconti, foi legal, porque eu aproveitei para fazer a crítica obrigatória a todo o processo. A 40 anos atrás era um outro quadro, esse hábito que é muito comentado que a mulher brasileira desperdiça e joga fora, poderia ser explicado muitas vezes que uma comida em um país muito quente fora da geladeira estraga, não guarda pra dar pra criança porque vai ficar doente. Mas uma geladeira é um equipamento de saúde, e eu até imaginava uma geladeira que fosse construída embutida no processo da construção, e o fogão também assim, e chegamos a fazer, e a geladeira foi feita em São Carlos, a geladeira custava $\mathrm{R} \$ 30,00$, custava menos que os enfeites de uma geladeira americana que a loja Mapin vendia, e o fogão custava $R \$ 10,00$, $\mathrm{R} \$ 5,00$, meu pai tinha uma fábrica de fogão, mandei fazer um. A geladeira embutia, você põe concreto ou tijolo, isola termicamente, põe um tampa, porque a geladeira importada não cabia, nem passava na porta. Fizemos pesquisa de mobiliário, mas tudo em vão porque não pode existir uma produção industrial que não tenha sido apoiada em uma pesquisa, e a indústria não embarca nem na pesquisa quando ela tem uma garantia de uma programação de reconhecimento, porque custa muito dinheiro produzir um mobiliário que inclui tudo, cadeira, mesa, cama. Tinha aqui um cidadão muito interessante, com quem eu estudei discutindo isso, 
leva 8 anos pra ter uma linha de produção andando, é muito interessante, porque você tem que fazer um estudo do pé da cadeira, tem que ser padrão ao pé da mesa, como automóvel ou uma indústria qualquer, mas não tinha nenhuma possibilidade de garantia, num tinha, então tudo ficou no mundo das idéias.

\section{Fabiana: Foram feitos os protótipos então? Só não foram colocados em prática.}

Fábio: Protótipos sim, mas tudo na base do paralelo. Um exemplo, o Brasil queria entrar numa linha de $\mathrm{BNH}$, etc. A gente pretendia ter um edifício para pesquisa, pesquisa de pisos, de tudo, divisórias fáceis de montar e desmontar. Nunca se conseguiu nada, como até hoje não existe, o primeiro laboratório descente de materiais foi feito pelo Falcão Bauer, eu convidei ele pra gerenciar a execução das obras, e a verba foi tão boa que deu pra ele fazer um laboratório de pesquisas, não creio que tenha havido muitas mudanças, mas o cidadão comprava uma casa popular, é uma vez na vida, é o máximo que ele busca. E comprar uma casa, pagar em vinte anos, oito dias a dobradiça encrenca, a fechadura não abre, é um desrespeito absoluto, em benefício do ganho do fornecedor, da empreiteira, isso era lógico. Até que houve alguma melhoria, mas é muito pouca. A CECAP, foi feito pra que ela ficasse com um laboratório de pesquisa para encaminhar intenções da construção de habitação social, mas não foi, tem muita contribuição duramente conseguidas, mas pontuais, não tem continuidade.

\section{Fabiana: 0 projeto foi pensado pré-moldado inteiro, ou depois que foi pensado?}

Fábio: Ele foi pensado pré-moldado inteiro, mas também por uma fantasia ou poesia, foi feito o projeto, calculado todo para pré-moldado, custou uma 
fortuna o contrato do projeto de estrutura pré-moldada. É mesma coisa, primeiro, não fazia parte e ainda hoje não faz parte da cultura, na época que a gente construiu. Segundo, se você faz uma usina e faz aquela obra CECAP, aí joga fora a usina, porque não teria outra pra fazer, o custo disso era tão grande que não foi, a única coisa pré-moldada lá foram feitas as escadas e alguns componentes. Que hoje você encontra em qualquer parte do Brasil, São Carlos, Campinas, todo interior do Brasil, o cara já faz uma escada de um prédio pré-moldada, já existe uma facilidade de mão-de-obra em tudo quanto é lugar, é só isso. Foi feito o projeto mas não foi usado! Além do mais, das 12.000 unidades pretendidas foram feitas, nem sei, 4.000 unidades.

Fabiana: Nem aqueles balcões onde seriam os armários, embaixo das esquadrias, foram feitos?

Fábio: (olhou as plantas que eu mostrei de pré-moldados e disse) É a escada.

Fabiana: Na primeira fase a escada foi feita de um jeito e na outra fase foi reformulada?

Fábio: É que não foi bem assim. Faz muitos anos, mas o Governador que era o Abreu Sodré, por uma gentileza, ele aprovou 400 unidades, era o que se conseguiu. Essas 400 ainda estavam ligadas a todo um conjunto de idéias renovadoras, aí quando começou e partiu pra segunda, essa primeira era quase que uma pequena amostra.

\section{Fabiana: Era aquela parte mais perto da Dutra?}

Fábio: Não me lembro. 0 terreno era muito maior. Tanto que algumas vezes, eu tive um amigo que era muito bom e muito competente, que era chamado Luis Antônio Pompéia que estudava coisas de cidade, eu trabalhei com ele quase 20 anos, e nós fizemos propostas já ao CDHU, de utilizar as áreas que 
sobraram, e foram vários estudos, vários cenários construídos, claro que nesse período de tempo, mudou tudo, aquele terreno que era o último terreno de uma região deserta, alagaço, hoje aqueles prédios lá tem condomínio fechado, tem guarda. (Fabiana: dez condomínios fechados) Essa moça conhece tudo, se você encontrar com ela, porque ela mora lá (falando sobre a arquiteta Solimar), ela sabe tudo. Eu to te contando a minha visão, a visão de quem assinou tudo o que ta lá. Fiz todos os contratos levando porrada e eu isolado, sozinho. A tentativa de transformar, quando você me perguntou, qual era o interesse de fazer, a contribuição que esse projeto poderia dar em tudo, na indústria da construção, por exemplo, eu pessoalmente mantenho uma idéia, enquanto $1 \mathrm{~m} 2$ de construção pesar uma tonelada, a tendência obrigatória de redistribuir peso, reduz a carga de desgaste do meio ambiente. Mas ela acabou como uma obra convencional, uma grande empreiteira assumiu, ainda tivemos sorte quando o Falcão Bauer gerenciando, quando, por exemplo, ainda no tempo do Zezinho, me lembro bem da conversa junto com ele, as empreiteiras vinham apresentar propostas, Camargo Corrêa, Odebrecht, todas essas, eu era a vítima do processo, eles tinham dez advogados, e eu falei pro Zezinho, só aceito isso aqui, se eles tem dez eu quero doze. Pra fazer um contrato, e eu já acompanhei contrato, o que é complicado de um contrato é não ser prejudicial a uma parte. E, eu convidei - Falcão Bauer e o Alfredo Paesani, que era meu sócio, no meu pequeno escritório, pra garantir que o gerenciamento da obra ia ser descente, porque a tendência no Brasil é tudo ir pro buraco, então com todo cuidado que você possa fazer, o difícil é que seja correto.

\section{Fabiana: Qual era o nome da empreiteira ou construtora que ganhou?}

Fábio: A primeira... conversei com a cara ainda duas semanas atrás, hoje é a ROSSI, o J oão Rossi, na época era ENGEVICS. Eu comentava com ele, e a gente tava na reunião de um projeto... tive no escritório dele, e lembrei que ele ganhou a concorrência. Houve grande intenção de marcar essa obra como 
um... não era pra ser bonitinha, seria uma linha de direcionamento para 0 pensamento arquitetônico e de técnicas de construção pra sair da Idade Média aqui no Brasil, mas é muito difícil e muito relativo porque quando se entra na escala dos problemas e de necessidades, são problemas terríveis mas em condições muito diferentes, não pode fazer todas as construções no Brasil com o mesmo condicionamento técnico ou arquitetônico, você tem lugares no Amazonas, no Ceará, até cidades grandes. Pra você ter idéia, por exemplo, eu trabalhei dois, três meses na União Soviética, num grupo chamado Técnicas e Materiais de Construção, era um grupo internacional, então visitamos canteiros de obras de várias regiões da União Soviética, além de Moscou, Armênia, Putzequistão (hoje Afeganistão), e outros lugares. Então tinha lá um conjunto dez vezes maior que o Zezinho Magalhães Prado. Era um detalhe, mais tinha um lá que tinha 400 mulheres, e fazia parte do grupo um amigo meu cubano que falava muito bem russo, então começavam a fazer provocações, então todas essas construções que eu vi a divisória era de gesso e depois coloca papel, e diferente do Brasil, lá o gesso é o que sobrou de gesso, ele é compactado com o que sobrou de lixo pra não ficar caro, então tem cavaco de madeira, pedaço de papel, mas achei que a planta da casa, na verdade, era muito feia... aí chamava as moças que trabalhavam e a gente falava, olha nós achamos que essa planta...elas falavam, nós também achamos, aí tanto que o vice diretor de obras, nós comentamos aqui com as moças e elas concordaram que é muito ruim, ele ficou bravo e disse, só que é o seguinte, nós não fazemos as plantas, todas são feitas em Leningrado, era uma bosta de planta, com pré-moldado pesadíssimo, mas pesado como se fosse obra de ponte. Pra você entrar num pré-moldado de habitação teria que ter um... é claro que vai chegar no Brasil, mas tem que comprar de empresas que eu acredito, que já a muito tempo estão pesquisando, Portugal, Espanha, Itália e França, principalmente os Estados Unidos, e quando explodir vai ter que chamar uma empresa dessas pra fazer milhões de obras no Brasil, porque na Faculdade de São Carlos eu ouvi dizer que tem alguém interessado em 
pesquisar e estudar, para isso teria que ter espaço, chão e dinheiro, tem nada né, mas nós continuamos.

\section{Fabiana: 0 projeto foi implantado em outras cidades do interior de São Paulo?}

Fábio: Não, eu tive com o Artigas, nós tivemos pesquisando em Americana, que foi um desastre, era um prefeito horroroso, descordava de tudo que a gente pensava e fazia, teve uma implantação de uma unidade pequena em

J undiaí, eu acho que só, e depois a CECAP, não mais a CECAP, o CDHU, está fazendo implantações em todo o Estado. (Fabiana: Mas não com o mesmo projeto, mesma unidade?). Unidades, acho que todas as obras tem unidades quase iguais, e quem tem na mão a incumbência de fazer alterações é o CDHU, de resto só tem essas. (olhou a planta da unidade) Aqui tem uma história acontecendo, essas paredes são removíveis, você tem facilidade de manejo.

\section{Fabiana: 0 como se chegou nessa unidade habitacional?}

Fábio: Foi feita uma unidade, depois um conjunto de unidades, depois que se passou a chamar de freguesia. Essa não era a planta original, a original... qual que é o projeto do Oscar Neimeyer para Brasília do fim da década de 50, também uma idéia interessante, mas é também dessas idéias, vamos dizer, poéticas. Teve um projeto do Canadá, você faz como se fosse um contêiner e monta um prédio, claro, não é fácil de fazer, principalmente o isolamento de unidade, barulho. E a planta original era praticamente toda livre, e tinha uma parede aqui que tinha fogão, tanque de lavar roupa, pia, e aqui tinha uma argamassa armada, uma privada e depois um chuveiro e uma portinha, tipo porta de marinheiro, bem bonitinha, essa eu que inventei. Essa planta eu levei ódio mortal da equipe arquitetônica, e levei para o meu escritório, aí o Artigas foi lá ajudar a complementar. Ele disse, uma planta como essa, para 
milhares de família, que pela primeira vez sai de um mundo rural e que nunca viram nada parecido, isso só poderia ser adotado se houvesse uma experimentação, por isso se fez, a CECAP chegou a ter 100 atendentes sociais. Admite-te que se faça esse espaço pra sua tia, pra você, se der errado é uma unidade, mas pra fazer pra 12.000, tem que ser feito convencionalmente, para grande ódio mortal do escritório, oficialmente eu não faço isso, era muito mais bonita a planta, mas eu achei impraticável, é você brincar com a responsabilidade, não dá pra se der errado joga fora 12.000, mas a população que vai morar, ela vem de um outro mundo, é complicado. Faltou, vamos dizer, no caso teve discussão, por exemplo, a geladeira que eu mandei fazer, ela foi recusada. (Fabiana: mas é essa que tem o desenho?). Ela nunca foi feita, a pesquisa de consultar, qual que era o problema da mulher daquela época. Podendo ir na loja Mapin, hoje é a loja Bahia, ela poderia comprar e pagar e vinte e quatro parcelas, porque ela vai aceitar uma que simboliza ela ser pobre? O papa da propaganda na época era o Roberto Dualib, na época a gente trabalhava junto, um cara de cinema, um de teatro, um de arquitetura, pensando que ia fazer uma alguma coisa interessante, mas não aconteceu nada. Aí eu falei, olha, a geladeira, um equipamento que a gente está propondo, precisa de 5 vezes mais verba do que você ganha pra fazer propaganda de uma marca estabelecida... e a pessoa consegue comprar em 20 parcelas a marca, é o consumismo. Mas imaginou se fizesse uma pesquisa, como seria função da CECAP, função do CDHU, você passa a orientar possibilidades, e avanço industrial, e avanço técnico-construtivo, que quem paga pra desenvolver já viu a antevisão que a coisa é possível, todo avanço na escala da coisa grande é complicado, ou você avança quebrando tudo, que é errado, o fato de ter que pesquisar e que é obrigatório é muito chato, precisa de tempo e até hoje não tem pesquisa. 


\section{Fabiana: As paredes foram feitas pelo método convencional?}

Fábio: Blocos de concreto. E as divisórias em gesso. 0 piso, por exemplo, foi estudado. Tinha uma empresa no Rio de Janeiro, claro que havia pisos de rolo, tipo Paviflex, permitia que você colocasse sobre o concreto colocasse 0 material, mas é de baixa durabilidade. Até hoje é difícil encontrar um piso de boa qualidade, bonito, de fácil manutenção, e que não seja muito caro. 0 Brasil precisa de $8,10.000 .000$ de habitações, cada habitação tem $50 \mathrm{~m} 2$ de piso, se você botar na escala do número, é uma produção industrial que vai levar uns 50 anos pra acontecer, enquanto não tem usa o tijolo, raspa terra, tem que carregar, tem que botar num forno que é gás, gasolina ou óleo, tem que carregar, que é um peso, tem que colocar no caminhão, que é um peso que estraga o pavimento da rua, vai subir 2, 3 até 10 andares, é uma loucura, as pessoas assentam de qualquer jeito, depois com a massa você corrigi. Com essa arquitetura da moda em São Paulo, que é a mediterrânea, é muito usada por uns tipos de pessoas, é a mais barata que existe, assenta o tijolo, depois põe a massa de qualquer jeito, aí fica bem ondulada.

Fabiana: E a metragem do apartamento era maior do que o convencional? Era um apartamento grande para a faixa que ele atingi.

Fábio: Eu acho que não. Esse daqui tem uns $50 \mathrm{~m} 2$, era o mínimo. Qualquer casa chamada popular a 40 anos atrás, sempre foi grande, hoje em qualquer cidade aí, a casa popular tem $40 \mathrm{~m} 2$, mas as casas eram grandes, com quintal, essa daqui é pequena. Mas repetir 12.000, o objetivo era 12.000 , mas não deu. Então acho que eu dei uma visão aberta de tudo.

Fabiana: Na época tinham alguns arquitetos que eram da oposição de vocês? 
Fábio: Na época tinham poucos arquitetos no Brasil, mas havia um posicionamento político no Brasil inteiro, a chapa que eu fui presidente era exatamente de quem não fazia acordo com nada.

\section{Fabiana: E com relação ao Sérgio Ferro e o Rodrigo Lefrève?}

Fábio: Ah não. O Rodrigo e o Sérgio Ferro, e o Sérgio Souza Lima, é dessa época, pouco depois, sessenta e poucos, tinha na FAU uma discussão muito interessante com o Flávio Império também. Mas é uma coisa muito pontual, uma discussão entre os estudantes, essa coisa de escola que ninguém sabe, que ninguém conhece, não tinha importância nenhuma. A importância é no mundo acadêmico. Não importou em nada no processo, na política, eram pessoas excepcionalmente interessantes, competentes, com muita coragem, que faziam uma pesquisa particular dentro da FAU, sobre coisas em geral. Claro que com visão política, de espaço e de mundo, faziam técnicas competentes e bonitas, mas não lembro de nada do...

\section{Fabiana: Nessa época do Debate na FAU eles não tiveram nenhuma importância? Não eram contra?}

Fábio: Esse debate. Você tem uma cópia de um debate, que só quem conhece é você que tem essa cópia e mais quarenta pessoas, essa que é a lástima. 0 J oaquim Guedes levantou uma questão aí sobre habitação, foi citado nesse debate, mas você nota que ninguém tem certeza de nada, mostra uma coisa que você está fazendo, mas não é verdade, como se fosse uma pesquisa que ninguém nunca irá fazer. Não é aquilo que está acontecendo, nem aquilo que está marcando o que está acontecendo. Que nem a obra de Guarulhos, a CECAP de Guarulhos, ta lá com portaria, etc..., claro que mudou tudo. 0 próprio Aeroporto de Guarulhos, que ainda não está completado, gera ali normalmente 40, 50.000 empregos, e o bom é o pessoal morar perto né, em todos os sentidos, se tiver ainda em condições agradáveis. 0 avanço na 
chamada técnica de construir, na maneira de projetar habitação social virou comércio.

\section{Fabiana: Depois do conjunto teve alguma diferença.....?}

Fábio: Não porque não existir, a não ser como pontualmente em Cumbica, porque pra existir tem que ter, como é que você vai usar uma técnica de construir que é inovadora e tem um custo em cima do que o mercado permite acontecer. (...) Por isso que ela é super rebuscada, com todo direito e toda razão.

\section{Fabiana: Por que não foi construído na totalidade, do que foi proposto?}

Fábio: Foi feito 5.000 e era tido como um absurdo. Era tido como um sonho, absurdo, até com ódio. Os números eram terríveis, pra você ter uma idéia, é muito bonito você fazer um projeto, projeto típico de arquiteto, põe área verde, tem o famoso espaço vazio ou verde, o prédio de Guarulhos, e eu estou te contando com detalhes porque era a minha função, tinha $500.000 \mathrm{~m} 2$ de área verde, o que acontece, eu tinha que administrar e fazer essa área verde, eu precisa orçar e ter o projeto, o que eu não consegui. Eu tinha um plano de pesquisa que seria, na minha opinião, o primeiro espaço de área verde para um conjunto de habitação ou cidade brasileira, não era brincadeira, parecia piada, pra que serve área verde, não serve pra nada a não ser pra gastar água, até proibido fazer manifestação, é um cenário para edifícios. Precisa de uma pesquisa, que tipo de jardim fazer que dê para usar, que seja bonito, na época era muito importante que não gastasse muita água. Tudo o que consegui, dos paisagistas chamados, é que faziam o projeto, quando ia se orçar na época, a área verde mais barata na época eram 20 dinheiros, multiplicado por 500.000 era um número de louco. Em uma escala pequena você fazia uma casa popular e plantar uma árvore que logo morre. Mas se fizer 10.000 com $10 \mathrm{~m} 2$ cada, dá $100.000 \mathrm{~m} 2$, nunca vai ter dinheiro pra fazer, 
não entra na mentalidade política gastar pra área verde. Então é muito complicado, quando você fala na escala do grande, o verde é que leva pau.

\section{Fabiana: Mas hoje tem várias praças entre os condomínios?}

Fábio: Tem nada! Eu digo área verde cada um fez o seu, mas implantar uma obra não vai ter verba nunca. Primeiro que era curioso, pois era $500.000 \mathrm{~m} 2$ de área verde, você passava vergonha. É fácil você dizer área verde, mas quando você assumir que a área verde vai existir, você tem que saber o que é a área verde, que tipo de área verde é essa, se falava até que devia se fazer uma pesquisa no cerrado, também poderia ser uma pesquisa muito bonita. 0 que é o jardim brasileiro? Nós não temos. As universidades teriam que ter pesquisas nessa área de pessoas relacionadas ao paisagismo. Se você fizer paisagismo de um condomínio, mas se for para as novas cidades brasileiras, se você botar uma população daqui a trinta anos, tem que colocar tudo que existe.

\section{Fabiana: E as garagens foram pensadas desde o início sob os pilotis?}

Fábio: Pilotis é pra colocar carro mesmo. (Fabiana: Por que tinham desenhado umas áreas de garagem na rua.) Por isso que eu disse pra você que era tudo um sonho. Quem iria imaginar que o operário lá ia ter automóvel. Eu conheço uma história, quando foi aberta a avenida 9 de J ulho em São Paulo, o prefeito era Fábio da Silva Prado, nome interessante, e duas pessoas estavam com o prefeito, um deles foi que me contou, vendo o escritório da prefeitura e tinha um cara muito jovem lá, que era o Prestes Maia, e com uma maquetinha muito precária, que o Fábio perguntou, o que é essa minhoquinha, aí o Prestes Maia foi explicar que era uma maquete na avenida 9 de J ulho, que ela abriu em 40, então isso deve ter sido em 37 ou 38. Ele perguntou, quantos metros tem? - Por que você acha que aqui vai ter tanto carro que nem Paris (prefeito). Porque na época Paris era o auge, aí teve um comentário que 
mandaram reduzir pela metade, a original era o dobro. O pilotis é charme, poderia ter deixado o pilotis que foi uma invenção, uma discussão do Corbusier interessantíssima (...) posso dizer que ninguém pensou em automóvel na época, imagina o cara ganhava um salário mínimo na época, quem ia ter carro? Hoje cada um tem dois. Hoje qualquer lugar você compra um caro pagando $\mathrm{R} \$ 80,00$ por mês, porque que existe essa indústria mal fadada que é a indústria do automóvel, porque o cara deixa de comer de ter melhor vida pra ter um automóvel, é uma máquina de consumismo. Hoje lá cada um tem dois, ainda deve alugar do vizinho. Hoje o aluguel lá, bom da última vez que eu tive faz uns três anos, o nome dela á Solimar, ela sabe de tudo e ela mora lá, é $\mathrm{R} \$ 1.500,00$ o aluguel lá, quando ficou pronto a prestação era $\mathrm{R} \$ 7,00$, eu tinha um desenhista que tinha muito problema, eu disse compra por esse preço por mês, e na época a mulher dele disse, imagina se eu vou morar nesse lugar.

\section{Fabiana: Então não houve nenhum tipo de interação de áreas verdes?}

Fábio: Se tivesse área verde seria ótimo, mas era um negócio de terra. Como eu ti falei, no CIAM feito na Grécia em 1940, ou antes, eles falavam, os verdes, as ruas, não sei o que... balela, conversa mole pra boi dormir. Mas os arquitetos pensam assim, então o cara vê área verde, como é que se faz o verde? Vai chamar o Burlemarx, não tem como. Ele ia fazer o conjunto lá do Pedregulho, imagina só que legal. 0 verde é um detalhe curioso, mas pra você fazer numa pequena habitação tudo bem. Mas pra 1.000, 10.000, 100.000 precisa fazer um novo estudo pra saber o que ela é. Entre desenhar e vir aqui fazer há um muro limitante, quando não existe essa realidade da pesquisa, o trabalho do arquiteto perde a base. (...) Vou te contar uma história, quando eu estava na CECAP, houve uma interrupção de todo programa a rede de televisão e rádio no Brasil, e o presidente da república, que eu chamava de "Mérdici" apresentou um plano fantástico de habitação, era o PLANAP, afirmou que com ele teria 680.000 habitações com condições de 
financiamento especial, para São Paulo caberiam 380.000, então o governador logo fez uma reunião pra assumir a parte de São Paulo e teve que chamar quem? A CECAP que era a única organização oficialmente montada para isso, aí então o que fez a CECAP, de cara comprou nove carros oficiais novos, na CECAP só se fazia política para se eleger deputado amigo, etc. Aí montaram a diretoria, etc. E aí houve uma reunião com os novos diretores e eu estava presente. Eu vinha da construção, não tinha um perfil popular, mas aí eu disse, antes de começar a reunião gostaria que cada um pegasse um lápis e um papel, e antes de começar eu quero contar uma história que é uma piada, mas é muito importante: no tempo do Vargas, quando ele não sabia se ficava do lado da Alemanha ou do lado dos americanos, todo mundo aguardando, ele quase ficou no lado dos alemães mesmo, tinha muito mais a ver o Brasil fazer acordo com Hitler do que com os americanos, e a Europa tava perdendo a guerra, aí resolveu ficar do lado dos americanos, então o navio dos americanos no porto esperando para fazer festa, o navio entrou no porto e não demos as obrigatórias salvas de canhão pra saldar um navio amigo que entra, e logo prenderam o tenente da marinha, então perguntaram a ele, 0 senhor tem alguma justificativa que explica seu ato, tenho 17 motivos, primeiro que não tinha pólvora. Então, 380.000 habitações que o Estado foi conferir, vamos admitir que cada uma delas seja menor terreno que existe, seja 5 metros de frente por 10 de fundos, $50 \mathrm{~m} 2$, bota um pouco de calçada, de rua, um hospital um dia, praça, vamos multiplicar esse número por 380.000, tem terreno, tem razão de fazer, tem quem possa pagar, tem desenvolvimento? Senão tem terreno como é que vai fazer casa? Acabou reunião e nunca mais se falou no assunto. Então quando se constrói aqui, alguma coisa, tem um terreno aqui e outro lá, um terreno ta ligado à rede de transporte importante, porque o terreno é muito caro né. Sem ter um projeto é muito difícil fazer uma obra competente, pra ser bem feito só pode ter conhecimento adquirido por pesquisa, não adianta ser genialmente brilhante pra escrever área verde, como é o caso de Corbusier na Índia, porque eu era uma das poucas pessoas que já tinham ido lá. O Corbusier era um arquiteto 
suíço, na verdade não era arquiteto, nem se formou, personagem colonialista, e foi fazer uma cidade no sertão da Índia, que é Koudjabi e Mariana, eu vi lá no projeto na parede que tinha escrito área verde, e não tinha uma árvore lá, e a Índia é um lugar que tem mais árvore no mundo, tem mais arvore que gente, lá num tem porque ninguém gostou, não foi feito, mas está escrito área verde, faça-se.

\section{Fabiana: E com relação à cobertura do conjunto habitacional? A argila expandida?}

Fábio: A argila expandida é uma solução que também deveria ser muito estudada, a idéia era do Balcão Bauer, eu aprendi que era possível... por exemplo na casa do Teru Temaki, mau grande amigo, meu sócio de 40 anos, ainda ontem estive na casa dele, é uma laje pré comum, vão de 7 metros, mais simples do mundo, tem trinta e poucos anos a casa, deixa o ambiente agradável, uma camada e tijolo, outra de concreto, deixa curar, endurecer o concreto, não é nem concreto, em cima do tijolo não é concreto não tem ferro nada, deixa embaixo d'água, a uma tendência de o material se contrair, se você deixar água o que acontece, pelo vapor evapora tanto a água que dá problema, então as bolinhas de argila expandida mantém sempre uma umidade em volta, deu perfeitamente. Eu tinha feito uma solução dessa, experimental, eu fiz no projeto do Clube Harmonia em São Paulo, que tem 40 metros por 40 metros, com vão livre, com Falcão Bauer meu amigo. 0 motivo principal era que ia colocar o que em cima de uma obra muito pretensiosa, e tinha contra-flexa, então dividimos em setores, e fundido o concreto, cobre d'água, fica curando o concreto dez dias embaixo d’água e assim foi....vazamento não deve ter. Mas é possível fazer, mas ninguém queria, uma vez, por exemplo, eu discuti isso na Bulgária, com uns amigos meus, eles não queriam acreditar porque achavam que eu era "porra-louca", queria provar, mas não acreditavam. 
Fabiana: Na época foi uma solução inovadora ou já estava sendo feito esse tipo de cobertura?

Fábio: Devem ter feito, deve ter lugar no mundo que deve ter feito, não tem nada novo. Inovador...é como uma coisa que eu li ontem, o cavalo perguntou se Deus existe? Uma coisa pra pensar depois. Você pode ter uma laje sem nada, a proteção, o calor mexe na laje claro, ali foi por um charme! Só que era um pouco arriscado, uma coisa de obra pública você não pode arriscar pra ter um erro, ainda que bote telha de barro, o que for, desde que aceitem, mas não pode ter erro. O atual diretor da FAU Chico Savaia, colocou telha de fibrocimento em cima da FAU do Artigas, quando ta frio ninguém agüenta embaixo, quando ta calor também ninguém agüenta, aquele domus precisa de um espaço para ventilar, entra pó, fica um pó que ninguém pode usar o espaço, é um raciocínio.

\section{Fabiana: Tiveram duas fases de construção do conjunto?}

Fábio: Teve a generosidade do governador que admitiu fazer as 400 unidades, que é nada para 12.000 .

\section{Fabiana: E elas foram construídas em que ano?}

Fábio: Olha, sei que foi antes de 70, 69, que nós iniciamos em 1967, quer dizer já são 40 anos, mas é por aí (...) só que não acabou, chegou a uns 40\% do previsto.

\section{Fabiana: eram previstos hospital, escolas, creches....}

Fábio: Da mesma forma como eu Ihe expliquei, a maneira de encaminhar esse projeto foi morar totalmente isolado, como se fosse alto suficiente, mas o certo era Guarulhos. 


\section{Fabiana: E sobre as cores da fachada, como foi o estudo?}

Fábio: Isso também é muito curioso, vou te contar, a obra já tava licitada e tinha que começar, mas pra fechar esse monte de fachada, a pintura tinha um peso, mas tinha que escolher a cor, quem que escolhe a cor. Um dia no escuro, isso é uma história antológica, tava o diretor, o Paulo Seixas Queiroz, de obra, tava um office boy nosso, o Chiquinho, a doutora Giselda e eu, e o chato do vendedor de tintas de uma empresa holandesa, aguardando. Aí eu pedi pra Giselda pegar a fachada do prédio, fazer uma, duas, três.....linhas que são os armários, desenhar e me passar, tiras de papel, e contei uma história que só essas pessoas ouviram, tem que resolver a cor do prédio, eu falei, a mocinha do interior chegou na loja de armarinho e pediu pro menino preciso de uma escova de dente, então ele perguntou "que co qué" e ela respondeu "caqué co", essa foi a história. Aí eu falei, vamos usar as cores básicas. A Giselda fez aquela tira, eu peguei a tira solta e embaralhei aleatoriamente, e depois peguei a tira e montei em cima da fachada, então ficou com um modo assim, assim, assim (mostrou no papel), cada uma das cores com suas tonalidades tinha T1, T2 .....até T8. Aí pegamos uma cor, vamos dizer, o vermelho, e o holandês da tinta dizia quais eram e assim foi feito. Se você fizesse como projeto, chamaria uma pessoa que faria um monte de cálculos, eu fiz em 5 minutos no momento que tinha que fazer. A Giselda conta muito bem essa história. O Artigas me dizia que eu nunca seria professor, porque quando chegava uma coisa dessa eu fazia e não dava explicação, eu resolvo. Depois que ficou pronto teve muita gente que foi tirar fotografia e tal, um jornalista escreveu que o Artigas devia ter pensado nas cores de Mário de Andrade, ele nem viu nada! Foi uma história engraçada. Mas as cores mudaram, precisava de algo com durabilidade melhor, geralmente são tons muito pálidos que duram mais, lá as cores eram fortes, o azul não dura três períodos de sol e chuva. 
Fabiana: 0 senhor sabe quando virou loteamento fechado?

Fábio: Foi acontecendo, os moradores assim que vão tendo uma identidade vão se isolando e vão se fechando. 
Entrevista com a arquiteta Maria Giselda Cardoso Visconti, realizada dia 09/04/2007, no apartamento da arquiteta, com início às $14 \mathrm{~h} 30$ da tarde. Entrevista realizada por mim, contando apenas com a presença de nós duas.

Giselda: Terminei a faculdade em 1958. Assim que me formei, prestei concurso e comecei a trabalhar no Departamento de Obras Públicas. Depois de três anos, fui para a França, como bolsista do Governo francês fazer um curso de"Industrialização da Construção". Quando voltei, estava indicada para participar do projeto do Conjunto Habitacional, na CECAP. Nos 12 anos que lá fiquei aprendi muito. Trabalhei no CONDEPHAAT, convidada pelo Ruy Othake, então Presidente do Conselho, onde permaneci por 4 anos. Depois voltei para o DOP. Comecei a dar aulas no Curso de arquitetura da FAAP há 14 anos. Fui chefe do Departamento de Proj etos e Coordenadora do Curso.

Fabiana: Com relação a obra do conjunto, a senhora era diretora de projetos de arquitetura da CECAP, e na obra era responsável pelo que?

Giselda: Era responsável pela coordenação dos projetos e preparação das concorrências. A cada etapa de obra o projeto era revisto. Na primeira e segunda etapa a estrutura foi executada pelo sistema tradicional, na terceira etapa a estrutura foi reformulada, usando fôrmas metálicas.

\section{Fabiana: Não foram feitos protótipos?}

Giselda: Dos equipamentos domésticos, somente o protótipo da geladeira foi feito pela Industria Clímax, em São Carlos. Para a terceira etapa da construção, estudamos caixilho de alumínio em conjunto com o Liceu de Artes e Ofício do qual foi feito protótipo. 
Fabiana: Então o maior grau de industrialização foi na terceira etapa?

Giselda: Sim. Execução da estrutura e paredes com fôrmas metálicas, escada, pré-fabricada, caixilhos de alumínio, modulados. Daí fizemos uma terceira concorrência, aí com sistema estrutural com forma metálica, mas com 0 Governo sempre é difícil, mas todos devem trabalhar porque a experiência é que vale a pena, a gente tem oportunidades que não tem em outros. Como a concorrência foi por melhor preço, os dois tipos de estrutura ficaram em concorrência, a tradicional e a outinord, e ganhou a outinord que era metálica e formava um $U$, era bem rápido e muito interessante.

Fabiana: Por que na época foram escolhidos esses arquitetos de renome, Artigas, Fábio Penteado e Paulo Mendes da Rocha?

Giselda: 0 Artigas foi convidado a elaborar 0 projeto do Conjunto Habitacional pelo então Superintendente da CECAP, Zezinho Magalhães Prado. O Artigas convidou o Fábio Penteado que convidou o Paulo Mendes da Rocha.

Fabiana: Em que época eles convidaram o Paulo Mendes da Rocha?

Giselda: Foi no início dos trabalhos, no final de 1967.

Fabiana: Quais foram às dificuldades para a realização do conjunto? Parte política? Industrialização?

Giselda: A dificuldade, na minha opinião, foi obter o financiamento do Banco Nacional da Habitação.

Fabiana: A obra era bem racionalizada?

Giselda: A qualidade da obra e o cumprimento dos prazos determinados, resultou, em grande parte, foi programação da obra. 
Fabiana: E sobre as cores da fachada? 0 Fábio disse que estava junto a você na hora da escolha das cores.

Giselda: Para cada edifício, dos oito que compõe um setor da freguesia, foi escolhida uma cor predominante sobre as quais foram estudadas cinco tonalidades. Todas essas cores compõem as fachadas.

Fabiana: $\mathbf{O}$ que eram exatamente as freguesias?

Giselda: Foi a denominação que o professor Artigas achou mais apropriada.

Fabiana: A administração já era condominial, apenas não era cercado como hoje?

Giselda: Cada setor da freguesia foi registrado como um condomínio, antes do inicio das vendas.

Fabiana: Tem alguma coisa no conjunto, olhando hoje em dia, que não deu certo? Que a teoria era boa, mas na prática não se realizou?

Giselda: As freguesias não eram cercadas, mas com os problemas de segurança, cada setor, hoje é gradeado e possui portaria.

Fabiana: Hoje lá virou moradia pra classe média, quais os fatores que influenciaram?

Giselda: A valorização da região foi muito grande, especialmente com a implantação do aeroporto. Na primeira fase da obra, o valor do metro quadrado de construção correspondia a um salário mínimo da época, era possível a população que tivesse renda familiar entre 3 e 6 salários mínimos, adquirir um apartamento, Atualmente a população que mora no conjunto é da classe média. 
Fabiana: As divisórias sempre foram de gesso?

Giselda: Na primeira etapa foram utilizadas divisórias de fórmica e nas outras placas de gesso.

Fabiana: E os armários eram pra ser feitos? Ou era só proposição?

Giselda: Os armários, na terceira etapa, foram completados com divisórias, prateleiras e portas.

Fabiana: Esse projeto, com o mesmo desenho de unidade foi implantado em outra cidade do interior?

Giselda: 0 projeto representou importante contribuição para outros projetos de conjuntos habitacionais da CECAP. 
Entrevista com o arquiteto Geraldo Vespasiano Puntoni, realizada dia $17 / 07 / 2007$, na residência do arquiteto, com início às $15 \mathrm{~h} 15$ da tarde. Entrevista realizada por mim, contando apenas com a presença de nós dois.

Geraldo: Eu, a Giselda e o Ruy Gama éramos funcionários do Departamento de Obra Públicas (DOP), e o Ruy Gama já estava assessorando e era comissionado pela CECAP, ela pertencia a Secretário dos Negócios do Trabalho, na ocasião, e ela financiava obras para operários, trabalhadores. Então, surgiu esse projeto e o Ruy Gama sentiu que precisava aumentar 0 número de membros da equipe, aí ele foi no DOP convidar arquitetos pra participar da obra, aí eu e a Giselda aceitamos o convite pra trabalhar lá. Fizemos parte da equipe e ajudamos a fazer os proj etos fisicamente.

\section{Fabiana: Porque era interessante sair do DOP para participar desse projeto na CECAP?}

Geraldo: Era interessante porque, nós éramos arquitetos no DOP e a gente fazia projetos lá, e quando surgiu essa oportunidade de fazer um grande projeto de edificações, porque no DOP a gente fazia projeto de escola, posto de saúde, reformas de prédios tipo fóruns. (...) Foi no plano do Carvalho Pinto que se incentivou a construção de escolas e criou o fundo estadual de construção escolar, ligado a Secretaria da Educação, e eu fui trabalhar lá, depois voltei para o DOP, aí eu achei interessante como objeto de trabalho, trabalhar em programas de habitação, aí aceitei o convite para ir pra lá. No fundo estadual eu era comissionado, e lá eu fui trabalhar como funcionário do Departamento de Obras Públicas, então tinha até uma diferença de honorários e salários, eu era funcionário público, mas a equipe que era contratada era diferente, os desenhistas que trabal havam para a CECAP ganhavam mais do 
que nós arquitetos. Mas de qualquer maneira foi muito interessante. O Ruy Gama andou filmando o Super 8, que é todo o processo do projeto, talvez exista esse documentário na FAU - USP. O Ruy Gama foi um cara muito importante, porque ele no Departamento de Obras Públicas, era um cara que tentou organizar as normas técnicas de quando o departamento começou a produzir, inclusive o caderno de encargos, o Ruy Gama foi o cara que começou a sistematizar esse tipo de apropriação, então ele era um casa muito interessado em pesquisa, tanto é que depois ele foi professor da FAU, fez um livro sobre tecnologia, infelizmente já morreu, mas foi um cara muito sistemático, na produção de conhecimento e técnicas construtivas e essas coisas todas. Aí nós fomos trabalhar lá, eu já tinha trabalhado, quando estudante, no escritório do Artigas, aí que eu conheci o Artigas, o Fábio Penteado, como a comunidade de arquitetos era muito pequena, a gente conhecia todo mundo. Saia da escola, estudei na FAU USP, na Rua Maranhão e ia pro IAB. Então todos esses arquitetos, quando não eram nossos professores, eram membros do IAB. Então o Artigas foi meu professor, o Paulo Mendes eu conhecia do $I A B$, a gente tinha um convívio muito grande, nossa classe era bem comunicativa, via sempre eles falarem e conversarem, o que era muito interessante. Agora o projeto em si, foi projetado visando um tipo de classe, e acabou desviando o foco, no final foi ocupado por outro tipo de classe. Até que 0 andar dos pilotis foi transformado em estacionamento.

\section{Fabiana: No começo não era pra ser estacionamento sob os pilotis?}

Geraldo: Não. No começo eram só pilotis, ninguém previu estacionar carros, inclusive o projeto tinha um plano mais ambicioso, inclusive eu fiquei encarregado de projetar, o arquiteto era o Artigas, mas eu era uma espécie de assistente dele na elaboração dos projetos das escolas, então se fez projeto de escola, de um centro comunitário, estádio de futebol, centro comercial, e nada disso foi executado. E se cogitava na ocasião, o Fábio Penteado deve ter comentado isso com você, que se comentava em entregar o apartamento equipado de geladeira, fogão, essas coisas todas...naquela época 
a família do Fábio era proprietária dos fogões Dako e a gente tinha feito alguns orçamentos e chegamos a conclusão de que valia a pena fazer 0 apartamento com esses equipamentos, mas aí surgiu uma questão, e foi contratado o serviço da mulher do Alfredo Paesani, a Eugênia Paesani. A Eugênia que era socióloga fez o levantamento de o que as pessoas que iriam entrar nos apartamentos consumiam, na época ela fez várias pesquisas nas lojas da época, tipo o que seria hoje as Casas Bahia, e ela descobriu que quem eram os maiores compradores de fogão e geladeira era essa classe. Então se chegou a conclusão que seria um absurdo as pessoas pagarem por equipamentos que elas já tinham, então a gente acabou com essa idéia de apartamento equipado. E desse ínterim se desenvolvia um projeto de préfabricação, nisso participou muito o Paulo Mendes da Rocha e o Arnaldo Martino, aí começou a fazer um projeto paralelo em transformar os edifícios em pré-fabricado, e tem todo o executivo disso, e tentou se regimentar pela Camargo Correa, uma firma que se propunha a construir porque era forte, conversou-se muito com a Camargo Correa e ela tava interessada em fazer a pré-fabricação, mas a gente sabe que o pré-fabricado absorve mão-de-obra na indústria, na fábrica, e pela política do BNH exigia que a obra fosse de modo tradicional, pois tinha dinheiro da CECAP e do BNH na obra. (...) O grande feito da CECAP foi a própria administração do Zezinho, o discernimento, o Ruy Gama que tinha a sensibilidade. O Ruy Gama é o pai ideológico, ele que fez com que o Zezinho contratasse o Artigas, ele foi uma pessoa chave, ele era a pessoa certa, no lugar certo. O Ruy Gama era como se fosse o cliente da obra, e ele influenciou o Zezinho, porque o Zezinho poderia até pedir projetos para o DOP, mas o Ruy salientou a importância do projeto ser significativo, expressivo, um ponto de pensamento, então foi muito importante a presença do Ruy, tem que enfatizar sempre isso. 
Fabiana: 0 Ruy Gama era responsável pelo que dentro do projeto?

Geraldo: Ele era o coordenador das atividades dos arquitetos junto a CECAP, ele não desenhava, ele era o assessor do Zezinho, então ele que era a comunicação, e possibilitou até a contratação, tanto é que foi ele que documentou.

\section{Fabiana: Até quando o senhor participou da CECAP?}

Geraldo: Até começar a licitação, antes das obras. Eu recebi um convite irrecusável e fui trabalhar na CESP, depois fui pra EMURB.

Fabiana: Eu gostaria de saber se tinham arquitetos contra a posição de vocês no trabalho da CECAP?

Geraldo: Com certeza. Um cara que era muito contra era o J oaquim Guedes, ele achava que os prédios tinham que ser todos de papelão, paredes préfabricadas leves, porque o Guedes sempre foi contra o Paulo Mendes da Rocha e o Artigas.

\section{Fabiana: E sobre o Rodrigo Lefèvre e o Sérgio Ferro?}

Geraldo: Esses não se manifestavam. Eles eram "cavaleiros da távola redonda", eles estavam em outro tipo de experiência, até porque o Artigas eram comunistas e eles eram trotskistas, sei lá o que eles eram, eles tinham divergências políticas, mas eles respeitavam o Artigas, tanto é que na reforma da USP eles não foram contra. Eles eram omissos com relação a CECAP, não que eles não tivessem idéias, mas nunca escreveram nada contra.

Fabiana: Foi importante participar da CECAP, principalmente com esses arquitetos? 
Geraldo: Foi significativo, importante, porque lá a gente recebia a incumbência e projetava realmente, não é que era "pau mandado", evidentemente que os projetos de escola o Artigas que tinha as idéias preliminares, mas eu que fiquei encarregado de grande parte dos projetos das escolas, isso porque eu já tinha trabalhado no Fundo Estadual de Construções Escolares, já tinha um gabarito muito grande nessa área. Eu participei da primeira equipe do Fundo Estadual de Construções Escolares. (...)

\section{Fabiana: 0 que deu certo na construção do conjunto?}

Geraldo: Na parte construtiva, foi se conseguir fazer um projeto em que se introduziu pilotis, já tinha isso, mas a sistemática de o térreo ser todo livre, esses princípios, eram quatro andares, a interdependência, preocupação com orientação e ventilação, essas normas todas construtivas, ser colocado em licitação um projeto executivo e não um projeto básico, tendo todos os detalhes. Foi a primeira vez que eu vi ensaios de materiais, pela assessoria técnica do Falcão Bauer, acabou refletindo no mercado. O estudo das cores, a Giselda participou disso, o cuidado. Na época tinha se pensado um abastecimento de água direto, sem caixa d'água. O sistema de cobertura, muito interessante. Uma série de coisas que foram ensaiadas. Na época pilotis tinham em dois conjuntos, um em Santo André e o Pedregulho, era muito rara a idéia de não usar o primeiro andar.

Fabiana: A idéia de se fazer um conjunto com tantos conceitos novos, não seria interessante ter reproduzido mais esses conceitos?

Geraldo: É complicada essa questão. A CECAP fez um projeto em J undiaí com o Artigas, e a CECAP tinha uns projetos de casas que ela contratava arquitetos só pra fazer locação, o óbvio dela era isso, mas o Zezinho não conseguiu impedir os prefeitos do interior que pediam pequenos conjuntos de serem realizados. 
Entrevista com o engenheiro Fernando Gonçalves, realizada dia 05/04/2007, no escritório do arquiteto Mário Savioli, com início às 9h00 da manhã. Entrevista realizada por mim, contando com a presença de Mário Savioli.

Fernando: Bom, eu sou o engenheiro Fernando Antônio Ramos Gonçalves, o pessoal me conhece por Fernando Gonçalves, sou engenheiro civil, formado pela Escola de Engenharia de São Carlos, da USP, em 1967, e eu tenho minha vida metade no setor público, metade no setor privado, e uma passagem que me orgulha muito é o período que eu estive lá na CECAP, que é hoje o CDHU, eu fui pra lá em junho de 1971 e fiquei até fevereiro de 1977, e foram 6 anos de um trabalho muito interessante. A história lá começa em junho de 1971, quando eu fui encarregado de coordenar a parte de implantação das primeiras unidades, que é hoje o Conjunto Habitacional Zezinho Magalhães Prado, e era o chamado Condomínio São Paulo. Eram 480 unidades e em fevereiro de 1977 quando nós saímos, estavam construídas 3.720 unidades, então a gente se orgulha muito desse fato. As primeiras 480 unidades, era um trabalho interessante porque a gente aprendeu muito, até em questão das técnicas construtivas, dificuldade na implantação, havia umas inovações importantes, principalmente estrutural, os prédios sem baldrame, eles tinham uma concepção que as próprias vigas na verdade travavam os três andares e 0 conceito de shaft, tão em voga hoje, já tinha sido proposto naquela ocasião, portanto a 40 anos atrás, e também as divisórias em gesso, que hoje chama dry-wall. E eu queria contar um detalhe interessante, a uns três anos atrás, eu fui visitar lá o conjunto com o meu genro, e ele trabalhava na INPAR, e hoje ele ta na GAFISA, ele tava todo entusiasmado com dry-wall, e nas conversas familiares ele falava que eu deveria conhecer, aí falei pra ele, esse negócio eu conheço há 40 anos atrás, ele disse que não era possível e era 
coisa recente, aí levei ele lá. Foi uma visita muito interessante, porque eu não me identifiquei inicialmente, só cheguei lá e disse que eu gostaria de conhecer e tal, até porque eu tinha receio, de repente aparece um cara aqui e diz que ta cheio de problema, 40 anos depois e de repente eu sou apedrejado aqui, mas o porteiro disse o seguinte, quem é o senhor, aí eu me identifiquei e a surpresa foi muito agradável, que eu fui recebido fidalgamente, tava lá o síndico, depois eu fui ver o apartamento, e no apartamento me receberam muito bem, cafezinho e tal, e meu genro ficou abismado com o que ele viu, ele disse, é isso que a gente ta fazendo agora! Pois é, estou ti dizendo, coisas que vocês estão dizendo pra mim que são novas, recentes, que são o up to date da construção, no Zezinho Magalhães Prado foi introduzido há 40 anos atrás. É o avanço, fruto de uma equipe de projetos de melhor nível, e como a equipe acompanhava a evolução mundial, e procurava alavancar e trazer pro Brasil o que existia de mais moderno. A par disso, nós tivemos lá um fato que eu julgo da maior importância, que depois de 40 anos está todo mundo lá, com manutenção adequada e perfeitamente habitável, que foi a fiscalização da obra e o gerenciamento da obra, e eu acho que também foi uma inovação na ocasião, trazer um laboratório de controle de qualidade do nível do Falcão Bauer para gerenciar um conjunto tido como popular. E com um detalhe, a baixíssimo custo, hoje quando eu ouço falar em gerenciamento de obra, escuto falar em 5 ou $6 \%$ do valor da obra, no Zezinho Magalhães Prado o gerenciamento da obra foi feito um contrato com o Bauer por $1 \%$ do valor da obra, isso envolvendo controle de todos os materiais e 0 gerenciamento da execução, com detalhes muito interessantes, eu comentava agora pouco aqui com o Mário, a respeito de uma especificação de fechaduras, que nenhuma empresa brasileira passava, então, La Fonte na época que ra a top e ainda é, não atendia as especificações da CECAP, e o Bauer desenvolver uma maquininha que controlava, acionava as fechaduras dos trincos, e a especificação exigia que a fechaduras resistissem a 100.000 acionamentos, nenhuma ultrapassava 45.000/47.000 acionamentos, inclusive a La Fonte, e nessa ocasião, abriu-se o mecanismo e verificou-se que tinham 
alguns elementos, especialmente um que acionava a lingüeta, que era em desamaqui, então a proposta foi fundir no lugar do desamaqui em bronze e aí foi pra 140.000 acionamentos, e a La Fonte passou a incorporar na linha dela a inovação, que foi um avanço tecnológico ditado pela obra. Então veja que estava na frente. Outra que foi interessante também foi caixilhos, e essa eu tive uma participação importante, inclusive levei um mandato de segurança que nós vencemos. Foi na segunda fase, nós já tínhamos desenvolvido com o Bauer, desculpe, o Bauer tinha desenvolvido um equipamento para testar caixilhos, onde simulava chuva, vento e ação simultânea de chuva com vento, onde o caixilho começa a tremer, isso em termos de ruído e vedação, então uma das condicionantes para atender a especificação era passar pela máquina do Bauer, e era um desastre porque ninguém passava. (Mário: Era menos máquina e mais tecnologia, os testes eram mais de tecnologia do que de máquina) Isso, exatamente, e o que aconteceu, o fato de ter que passar pela máquina do Bauer mudou todo conceito de caixilho, todo mundo teve que se ajustar, e passou a ser exigido das obras, inclusive comerciais de incorporações, passar pela máquina do Bauer, e aí aconteceu um fato muito interessante, que é essa passagem, já na segunda fase, não eram mais os 480 apartamentos, era uma quantidade maior, foi feita a maior concorrência que se tem conhecimento no Brasil, de fornecimento de caixilhos. Era um pouquinho mais de 7 quilômetros de caixilhos, concorrência nacional e eu me recordo disso, porque eu presidia a comissão de licitação, e componente da comissão, nunca me esqueço disso, Maria Giselda Visconti que era chefe de projetos (foi diretora da faap), e o Dr. Bento Vidalgo, que era um advogado de excelente nível, já falecido. E foi muito interessante, porque no momento da licitação eu tinha uma empresa de Brasília (Tabatinga), uma empresa de São Paulo importante que era a Ficher, que inclusive forneceu toda a estrutura do Anhembi, e tinha o Liceu de Artes e Ofícios, e na abertura dos envelopes houve um problema porque a Ficher impugnou o Liceu de Artes e Ofícios, alegando que ela não pagava os impostos totalmente porque era uma escola, e como escola tinha algumas isenções, e portanto não havia isonomia 
no processo licitatório, só que as certidões, os atestados de todas elas estavam perfeitas, e eu como presidente da comissão, meu interesse era ter maior número de licitantes e eu homologuei o resultado homologando os três, contra a impugnação da Ficher, e a Ficher entrou com mandato de segurança, um professor da Universidade de São Paulo foi o patrono, nós nos defendemos e ganhamos o mérito. Na licitação, o concorrente atendeu, portanto não tinha motivo para ser desclassificada. A questão de isonomia tributava extrapolava o nível da comissão, vai discutir isso no Supremo Tribunal Federal, em outra esfera, aqui está editado. E acabou o Liceu ganhando realmente e foi um fornecimento de muito sucesso, de bons resultados, passou na máquina do Bauer e está lá até hoje. Nesse momento aconteceu outro fato que também muito importante, nós mudamos as especificações dos caixilhos, que eram de ferro para alumínio, isso foi no começo da década de 70, e um fenômeno que até então não se constatava em São Paulo, começou a aparecer, algo muito parecido com chuva ácida, principalmente lá em Guarulhos, onde o ferro sofria uma ação muito próxima da maresia, a ponto dos portões daquele centro comunitário, da escola que foi feita, dos gradis, em meses aparecer corrosões enormes, e aí vem o mérito talvez da CETESB, dos órgãos de controle ambiental que conseguiram reverter de certa forma isso em São Paulo, mas naquele momento isso detectado inclusive lá, nós decidimos então mudar a especificação e introduzir o alumínio, que é mais leve e tem um custo um pouco maior. E o terceiro detalhe que me parece chamar a atenção, foi no momento que fomos entregar as primeiras 480 unidades, o conjunto foi construído num padrão tão popular, ele atendia, veja só que interessante, aquele padrão que hoje é praticamente de classe média, as primeiras unidades atendiam favelados, a ponto que foram contratadas oito assistentes sociais pra preparar os futuros moradores para viverem no apartamento, porque o conceito dele, era um conceito dos mais rudimentares, a ponto de quando falava de vaso sanitário, eles pensavam que era um lugar para por flor. Então, para se tirar alguém de um barraco de favela e trazer para um apartamento, precisava quase que doutrinar a família, e esse trabalho foi 
feito por oito heróicas assistentes sociais...teve um caso de um apartamento de 65m2 uma família com 11 foi morar lá, precisava de triliches e quadriliches, e conseguiram colocar 11 pessoas dentro. 0 que se lamenta depois disso, é que me parece que o sucesso foi tão grande, que grande parte ou a maioria desses primeiros moradores acabaram vendendo, saindo de lá, vendendo com ágio, e saindo de lá não sei se voltaram para os barracos, e por outro lado deu um up grade no conjunto habitacional, cuja origem era ser destinadas as pessoas de baixa renda mesmo. E depois do meio para diante, aconteceu um fato interessante, que foi a definição de Cumbica, e a própria execução do aeroporto, que aconteceu depois do Zezinho Magalhães Prado, promoveu uma grande mudança nos moradores do conjunto, o fato de ter um aeroporto ali, o conjunto passou a ser procurado por aeroviários, que não eram os aeronautas, aeronauta é a comissário de bordo, comandante, tal...o aeroviário é aquele que trabalha no solo do aeroporto, check-in, e houve uma demanda imensa, e hoje o conjunto é, segundo me informaram, que é um local muito procurado pelos aeroviários, para residir pois fica próximo ao aeroporto. E houve um detalhe também que eu preciso contar, porque é uma historinha muito interessante, nessa ocasião de construção do conjunto nós tivemos notícia de que aquela ponte, tem uma ponte ali ao lado do Zezinho Magalhães Prado na Via Dutra, e que houve uma licitação em que a construtora Alvi Círio tinha ganho pra fazer a nova ponte, sobre o rio Baquirivu, e eu fiquei sabendo daquilo, e eu conheço um pouco do planejamento da grande São Paulo, e eu me lembrei que o rio Baquirivu o que é hoje a Hélio Schmidt, que é um acesso, é uma das marginais, provavelmente você não saiba disso, no conceito original do plano estratégico para São Paulo, ela é um pedaço do Rodoanel, do grande anel rodoviário no conceito que veio da época do Figueiredo Ferraz e 0 .... de Freitas, São Paulo teria dois anéis, o pequeno anel e o grande anel rodoviário, o rodoanel atual não fica nem no grande nem no pequeno anel, ficando intermediário, o grande anel circundaria São Paulo, a Grande São Paulo na altura de 40 km da praça da Sé, um trecho dele é a interligação Anchieta/Imigrantes, do alto de 
serra, outro trecho dele seriam as marginais do Rio Baquirivu. Ao perceber que iriam fazer uma ponte, e essa ponte ia ser construída no mesmo nível da antiga, se 0 aeroporto fosse ali mesmo, o acesso estaria comprometido porque o gabarito não seria suficiente, peguei um avião e fui ao Rio e por uma circunstância favorável, sorte, o diretor do DNER, chamava-se Olegário Nogueira de Sá, meu parente lá de Minas e eu não sabia que era parente, porque a minha avó tinha o sobrenome Nogueira de Sá, aí perguntei o senhor é de Baipendi, minha família é de Baipendi, então nós somos parentes porque minha avó de Baipendi, é Nogueira de Sá...aí ficou tudo mais familiar. E eu desenvolvi meus argumentos e disse para o Olegário que ele estava cometendo um grave erro, São Paulo tem previsto ali um anel rodoviário, se o senhor vai fazer a ponte nova, construa já prevendo a possibilidade de lá passar o anel rodoviário. Ele aceitou a tese e mudou o projeto, elevando o gabarito a 5,50 m, que é o gabarito rodoviário, isso explica porque que naquele local a Dutra faz uma corcova, da Ayrton Senna, do lado do Zezinho Magalhães vai ver que ela sobe depois cai do outro lado.

\section{Fabiana: Lendo eu não consegui saber exatamente o que era a CECAP? 0 que ela já tinha feito até o conj unto?}

Fernando: A CECAP foi constituída como uma autarquia, chamava-se Caixa Estadual de Casas para o Povo, no governo Abreu Sodré, por iniciativa de um Deputado Estadual chamado Zezinho Magalhães Prado, natural de Jaú, representante da região de Jaú, e o Zezinho Magalhães Prado foi o primeiro presidente da CECAP, e o conceito dele era criar casas que atendessem as necessidades da baixa renda, naquela época havia no Governo Federal uma instituição chamada Fundação da Casa Popular, o grande problema era que como não havia correção monetária, e havia uma inflação galopante, as casas financiadas pela Fundação da Casa Popular ou pela própria Caixa econômica do Estado, na verdade não eram financiadas, eram dadas, porque era juro de tabela pratice, sem correção, então foi financiado em 20 anos, com uma 
inflação maluca, no final a prestação ficava de 20 centavos, da moeda da época. Na verdade a Fundação da Casa Popular, ela não se auto sustentava porque ele não tinha reposição adequada, em 1964, no governo militar foi incidido o mecanismo da correção monetária e foi criado o BNH, então a partir daí passou a se criar um financiamento que tinha condição de se auto sustentar, que é o que perdura até hoje. Quando o BNH foi extinto no Governo Collor, a carteira foi transferida para a Caixa Econômica Federal, então os recursos vinham do tesouro do Estado inicialmente, através da Caixa Econômica do Estado de São Paulo, e era uma autarquia, ela trabalhava com recursos públicos.

\section{Fabiana: E que obras foram feitas antes do conjunto?}

Fernando: 0 grande sonho do Zezinho foi esse de Guarulhos, começou tudo ali, depois se expandiu para o interior, e nós fizemos nesse período de seis anos, conjuntos habitacionais em 132 municípios, isso na minha gestão, eu era o diretor responsável por projetos e obras. Eu comecei na autarquia, depois a autarquia se transformou em empresa, no lugar da Caixa Estadual de Casas para o Povo, ela se transformou em Companhia Estadual de Casas Populares, que em seguida passou a ser a Companhia de Desenvolvimento e Habitação Urbana (CDHU), entendeu-se que além de construir as casas havia outro problema que era a urbanização do bairro, e inclusive para suprir água, esgoto, infra-estrutura viária, etc. Então se decidiu que os financiamentos eles não só atenderiam a casa, mas também atenderiam a urbanização, além do que deram outras funções que eram substituindo parte do DOP, e que agora fez segmento com a Companhia Paulista de Obras e Serviços (CPOESP).

\section{Fabiana: E porque deu esse nome ao conjunto?}

Fernando: Porque o Zezinho Magalhães Prado morreu e a obra dele ficou interrompida, e ele morreu entre 69 e 70, mas eu não estava na CECAP ainda, 
porque eu fui pra CECAP na transição do Governo do Sodré para o Laudo Natel, quando 0 Governador Laudo Natel assumiu foi indicado 0 superintendente da autarquia, depois o presidente o Dr. Juvenal Juvêncio, que hoje é o presidente do São Paulo Futebol Clube, e o doutor J uvenal me convidou então, eu tava na DERSA, eu era o gerente da Anchieta/Imigrantes, o primeiro gerente da Anchieta/Imigrantes, e eu fui convidado pra ir coordenar a implantação do Zezinho Magalhães Prado, e pra mim foi uma grande honra porque essa época, 1971, eu tinha 28 anos, então uma responsabilidade importante num momento que eu tinha todo o pique. Então, o J uvenal deu segmento ao trabalho iniciado pelo Zezinho Magalhães Prado, 0 Zezinho Magalhães Prado morreu de enfarto, ali na Brigadeiro, ele jantou ali na pizzaria Urca, foi pra casa e teve o enfarto.

\section{Fabiana: Como foram escolhidos os arquitetos para a obra, o Artigas, o} Fábio Penteado e depois o Paulo Mendes da Rocha?

Fernando: É uma boa questão, eu não sei ti dizer. Naquele momento, isso foi logo depois da revolução de 64, havia um tumulto na área acadêmica, alguns professores afastados, e o Zezinho Magalhães Prado, ele foi eleito pela UDN, que era um partido de direita, mas um partido de direita com uma visão nacionalista, tanto que o conceito da UDN, o slogan era "eterna vigilância", ou seja, era uma fiscalizadora dos atos públicos. Mas ele tinha uma grande preocupação social, e ele foi buscar no meio acadêmico expoentes, em termos de arquitetura, e que tivessem também essa visão social, ou seja, naquela época se dizia que visão social se confundia com uma visão de esquerda, apesar de ser um homem de partido de direita, e era muito comum isso, e tem uma coisa que eu preciso ti falar, que me deixa indignado, eu escuto muito esquerdinha de hoje, ocupando cargos importantes do Governo, e eu diria pra você o seguinte, hoje eu vejo, em determinadas situações, mais perseguições do que houve lá, proporcionalmente, eu perdi três colegas nessa ocasião, isso também me revoltava, mas eles eram elementos ativos, sem 
dúvida nenhuma. Então, há uma situação aí, que historicamente ela precisa ser revista, principalmente pra vocês jovens. A história contada, eu tenho lido, não corresponde a história que eu vivi, agora pode ser que eu até esteja enganado. O que eu via, como é caso do professor Artigas, um homem que foi caçado na função acadêmica nessa época, da mesma forma que foi Fernando Henrique Cardoso, só que o FHC foi embora e o professor Artigas ficou, e o professor Artigas o Zezinho Magalhães Prado o abrigou para ele construir o conjunto, com mais um detalhe, dos últimos meses do CECAP, eu me lembro que nós fazíamos muitas brincadeiras com o professor Artigas porque ele passou a projetar pro exército, ele projetou um quartel em Macapá, porque ele caiu nas graças, e tinha um coronel lá gostou do trabalho dele e resolveu... A gente brincava muito com ele, dizia, pois é o senhor que é amigo dos milicos aí. Não sei se o Artigas trouxe o Fábio, mas o Paulo Mendes da Rocha com certeza. O Artigas e o Fábio tinham escritório no mesmo prédio, no $I A B$, na Bento Freitas, e o Fábio foi presidente do $I A B$, inclusive durante 0 processo revolucionário. Inclusive nessa passagem, agora uma piadinha, fala com o Fábio que ele confirma, o Fábio era presidente do IAB Nacional, e o secretário do IAB Nacional era irmão do Ministro de Relações Exteriores, que era Silveira, do governo militar, e o irmão do ministro era o Silveirinha, que não se afinava com milicos, apesar de o irmão ser...E como tinha interceptação telefônica, os grampos né (isso vale como piada), o Silveirinha, quando o Fábio pedia pra ele fazer uma ligação, Silveirinha liga lá pra mim pro fulano, a hora que ele ia passar a ligação ele falava no telefone: Atenção, atenção, vai falar o presidente do IAB, gravando!!!!! Detalhe, um dia o FMl chama perguntando porque estava fazendo esse tipo de ironia?

\section{Fabiana: Quais as dificuldades na realização da obra?}

Fernando: A dificuldade de sempre eram recursos, mas depois que o BNH foi implantado, e a própria Caixa Econômica Estadual fluía os recursos, não era fácil aprovar os projetos, mas os recursos vinham. (Mário: com relação às 
fundações, era um brejo lá, era alagada a região). Mas a maior dificuldade que tivemos foi implantar água, esgoto e pavimentação, que era responsabilidade da prefeitura de Guarulhos, e aí tinha um jogo político que tinha que ser feito, como Guarulhos tinha base aérea, o prefeito de Guarulhos era escolhido pelo Governo Central, era o interventor, e o J uvenal habilmente vivia telefonando pro interventor dizendo o seguinte, olha nós vamos inaugurar agora a próxima fase e o Presidente da República vem inaugurar, eu não posso inaugurar aquilo lá sem água, sem esgoto, sem pavimentação, vocês precisam fazer alguma coisa lá, aí ele falava, se o Presidente da República vem eu faço, e fazia, assim a gente conseguia que fosse implantado. Detalhe é que o presidente nunca foi lá.

\section{Fabiana: Quanto tempo durou a obra e em quantas etapas foram feitas?}

Fernando: Essas 3.720 unidades elas começaram...., quando eu cheguei em junho de 71 , elas estavam nas fundações das primeiras 480 unidades, quando eu saí em fevereiro de 77, estavam em acabamento, estavam sendo entregues as últimas das 3.720 unidades. Depois disso, que eu saiba não foi construído mais nada, só o Hotel De Ville.

\section{Fabiana: Quais as empreiteiras e construtoras responsáveis pela obra?}

Fernando: Por toda a obra foi a Rossi. A Rossi existe (plano Cem), o dono da Rossi era e ainda é a família Cupoloni, J oão Rossi Cupoloni e o Edmundo Cupoloni, e o diretor técnico era o Roberto Ari. Quem tocava a obra era um engenheiro chamado Manoel Carvalheiro. 


\section{Fabiana: Por que houve mudança no projeto? Escadas?}

Fernando: Dessa fase eu não participei. Eu, quando cheguei, o conceito já era de apartamentos de três andares sob pilotis, e as fundações já estavam em execução. (Mário: mas essa parte eu respondo depois, porque eu saí em 79).

\section{Fabiana: Com relação à cobertura com argila expandida?}

Fernando: Aquilo lá é uma questão técnica, qualquer concreto, desde que ele não sofra dilatação durante o processo de cura, ele não tem porque trincar. (Fabiana: Mas já era usada essa cobertura, ou a idéia veio de fora?). Não, ela foi um avanço, mas foi uma idéia até do Bauer, do pessoal que tava acompanhando a obra, e foi um risco assumido e que deu certo, o problema era manter o nível d'água. Durante a fase de cura do concreto é fundamental, mas o conceito depois era o seguinte, se não for mantido com insolação, propaga dilatação, retração e começa a parecer fissura e começa a entrar água, então o grande receio era não deixar secar a água, depois que foi entregue a responsabilidade ia ser do condomínio e que pagava pela água, porque a água era fornecida pelo serviço de água de Guarulhos, e aí então, começou a se desenvolver umas bóias, que a água mantivesse o nível, mas não tinha altura, então você precisava, mas a bóia batia no fundo, então precisou ser desenvolvida bóia plana, para que ela pudesse ter sensibilidade, e a bóia travava, se a bóia não ficar mexendo sempre o eixo trava, então precisava ir lá ver a bóia, ver se a laje secou ou não secou, isso era um problema. Outra coisa que aconteceu foi o seguinte, no projeto houve uma proposta muito interessante, foi de estufar o apartamento, os armários eram projetados pra fora, embaixo dos caixilhos, uma forma de aproveitar o espaço interno, e então criava um pequeno balanço e a alvenaria de bloco de fechamento trincava, e pela movimentação, pela trinca, entrava água, aí nos apanhamos bastante. (Mário: mas foi substituído isso depois) Mas os primeiros nós apanhamos. E o material era bloco com argamassa de cimento e areia, e 
pintura externa e acrílico, que era uma resina, que tinha por finalidade impermeabilizar, como ela era rígida, trincava.

\section{Fabiana: Qual era o grau de industrialização da obra? Tinha muita coisa pré-moldada ou pré-fabricada?}

Fernando: Não. (Mário: o projeto inicial eu descobri acidentalmente lá dentro, era todo pré-moldado e tinha uma perspectiva explodida, mas o BNH não consentia que isso acontecesse). Bem lembrado, nessa ocasião, nós recebemos inclusive uma visita de uma construtora francesa que tinha feitos conjuntos habitacionais enormes na União Soviética, em Moscou, eles se propunham...a Camargo Correia se propunha a trazer essa tecnologia outinord, e o BNH vetou porque ia tirar emprego da construção civil, numa faixa de renda que precisava de emprego, na medida que se industrializasse ia substituir de não formação profissional, por mão-de-obra com formação, mãode-obra industrial, e isso ia gerar desemprego, então a preocupação foi de manter o emprego na construção civil (...).

Mário: O segundo calculista chamava Zé Luís, ele substituiu as alvenarias dos armários por vigas, daí a gente estava em uma reunião e o pessoal falou, olha não dá pra fazer isso, e o Artigas falou, dá sim, e calculou na hora e falou, eu quero essa viga aqui, o Artigas tinha isso (...).

Fernando: Depois a Rossi criou uma estrutura tubular, onde ela fundia uma laje em três dias. Montava, fundia com cura a vapor, fazia os testes e ensaios, e desformava em três dias, e tinha nervuras. 
Fabiana: Gostaria de saber se tinham relatórios mensais da obra e se tinha algum tipo de fiscalização?

Fernando: Foi extremamente controlado. O mecanismo funcionava assim, 0 Bauer fazia todo material que entrava na obra passar por ensaio, então era aprovado pelo Falcão Bauer, a qualidade do material. O Bauer mantinha na obra o Fausto Marioni, era um tecnólogo que acompanhava toda a execução, com uma marreta na mão, quando uma parede estava mal executada ele já chegava e derrubava, ele era odiado na obra pelos mestres. E a gente tinha um grupo de profissionais que acompanhava o trabalho que era executado pelo Bauer, porque ao acompanhar, esse pessoal era treinado para os 132 conjuntos que estavam espalhados, que era uma escola de formação para os outros conjuntos. 
Entrevista com o arquiteto Mário Savioli, realizada dia 05/ 04/2007, em seu escritório, com início às 10 h30 da manhã. Entrevista realizada por mim, contando apenas com a presença de nós dois.

\section{Fabiana: Para uma apresentação, qual foi a sua participação na CECAP?}

Mário: Meu nome é Mário Savioli, eu sou arquiteto, formado pelo Mackenzie em 75, eu entrei na CECAP em 1973 como estagiário e eu estava no 3o ano da faculdade. A estrutura da CECAP era muito pequena, era um prédio de 4 andares da Oscar Freire com a Avenida Rebouças, quem desce a Rebouças, a primeira esquina á direita, era um prédio acanhado com um elevador só, no quarto andar ficava a diretoria, no terceiro andar ficava o departamento técnico, no segundo andar ficava a área ilustrativa, ficava os psicólogos, os sociólogos, e essa equipe toda. Quem me levou para a CECAP foi o Fernando e me apresentou a Giselda e me colocou já na sala de desenho, com uma pessoa que tecnicamente era excelente, que era um iugoslavo chamado Stirpan Dragutini, você encontrou o Stirpan? Ele morou no condomínio São Paulo, acho que no primeiro apartamento do condomínio São Paulo. Naquela época eu tinha uns 23 anos, o Stirpan devia ter uns 70 anos, a formação dele era engenheiro civil, era arquiteto, e dizia que era engenheiro naval, e o Stirpan que desenvolvia toda a parte de escritório, a parte técnica, desenhava todo 0 sistema viário, fazia todas as previsões de cotas, de locações de estacas, e fiscalizava a gente no processo de desenho. Ele e a Giselda com a assessoria do Paesani é que acabaram montando toda a parte técnica do projeto no escritório, eu nessa época era desenhista e ajudava esse pessoal todo a preparar as licitações, quando eu entrei só havia o condomínio São Paulo, esse já tava executado, pronto e não havia mais problemas, eu comecei a pegar da segunda implantação em diante. O Fernando já ti contou isso, mas ele não 
contou sobre o abastecimento de água do conjunto, que é uma caixa central, toda a água vem da rede, vai para os apartamentos, porque os prédios não têm caixa d'água. A água vai para a caixa central, quando ela acaba na rua, há uma válvula de retenção, e da caixa d'água a água desce e abastece os apartamentos. (...) O Fernando não lembra desse detalhe, mas a mudança das escadas aconteceu da seguinte maneira: eles quiseram industrializar 0 conjunto (isso é pós Fernando), então eles montaram um sistema de formas de aço, fundiam uma laje, colocavam a forma de aço, fundiam outra laje..., isso eles conseguiram resolver, o que eles não conseguiam resolver era como colocar a escada, porque se eles fundissem a escada, a lança do guindaste não conseguia colocar a escada entre os dois prédios, então o projeto da escada foi refeito várias vezes e durante muito tempo ficou da maneira artesanal, e quando o projeto foi refeito, isso em 78, para que as outras fases fosse prontas, porque mudou muito da estrutura do projeto, aí não havia mais BNH pra trazer problema com mão-de-obra, aliás a mão-de-obra já era mais escassa, nessa época já havia o controle maior da tecnologia do concreto, então as peças que estavam dando problemas, trincas, foram substituídas por vigas de concreto. Se você olhar hoje esses últimos prédios, o que naquele tempo era alvenaria e fazia os fechamentos dos armários externos daquelas faces coloridas, passou a ser uma viga de concreto que fazia parte da estrutura do prédio, então os armários foram de tal maneira assimilados pelo apartamento, o fechamento dele, foi à própria viga de concreto que passou a sustentar o prédio, isso já nessa última fase, tanto que alguns detalhes deixaram de existir, esses armários eram segmentados, eles passaram a serem contínuos, e essa foi à montagem dessa última fase. Eu estou contando tudo isso, porque quando o Fernando saiu quem praticamente gerenciou o processo fui eu, na medida em que a Giselda passou a ser a Superintendente de toda a área de projeto da CECAP, e a CECAP se expandiu e foi para todo interior, a partir do conjunto. Quando a CECAP deixou de ser autarquia e virou companhia, ela se expandiu atendendo os planos do governo. Se você olhar as obras da CECAP na verdade tem conj untos de 20 casas, de 50 casas... depois a 
CECAP foram anexando outros parques, então a Giselda não tinha mais tempo de cuidar de tudo, os últimos projetos, as últimas licitações fui eu que cuidei de tudo, daí entrou o Paulo Maluf e mandou embora o Alfredo Paesani, Giselda e outras pessoas e eu acabei pedindo demissão, eu ia ficar fazendo 0 que lá? Esses conjuntos habitacionais que tinham as casinhas não interessavam, neste momento eu já estava formado a quatro anos, então em 79 eu acabei saindo da CECAP junto com eles.

\section{Fabiana: Você ficou até o final da terceira etapa da construção do conjunto?}

Mário: A terceira etapa eu não vi sendo construída, mas eu preparei todo o projeto para que eles fossem construídos. Mas a CECAP na verdade a partir daqueles pequenos conjuntos e desse conjunto se tornou uma grande fábrica de conhecimentos, porque os arquitetos que estavam lá e era uma equipe grande, os arquitetos foram se tornando extremamente competentes no projeto, no desenvolvimento, na metodologia de habitação popular, de tal maneira que não só a implantação passou a ser interessante, mas como a unidade, as pequenas unidades começaram a ser estudadas. Se estudou formas metálicas, se estudou toda tecnologia possível, no limite, quando a gente tentou baratear, o processo inflacionário era terrível. Então nós fomos barateando todas as unidades eliminando o que havia de mais caro até que um dia a gente apareceu com um desenho que era um fio, um soquete com um paninho amarrado num arame, e o pessoal perguntou, porque o paninho amarrado no arame? Você pega o paninho e vira a lâmpada, o paninho é pra não queimar a mão. Era uma forma de ironia do o projeto, aí nesse momento eu saí da CECAP e não sei mais... A Denise entrou um ou dois anos depois de mim, está na CDHU até hoje, mais a melhor pessoa que tem informações lá dentro é a Irene Borges Rizzo, que inclusive fez Mackenzie comigo, e ela inclusive é diretoras lá dentro. 
Fabiana: No começo foram feitos desenhos de protótipos, porque não deram certo?

Mário: Embora a nossa industrialização tenha sido implantada no começo do século XX, a industrialização da época não era grande coisa, e os arquitetos mais velhos, além de projetarem as casas eles projetaram o mobiliário também, se você pegar esse projeto do Artigas você vai perceber isso, agora a grande finalidade era diminuir, viabilizar e reorganizar os espaços dos apartamentos, esse era o grande objetivo, mas acabou não dando certo, a indústria acabou resolvendo isso de uma maneira muito mais eficaz que os desenhos dos arquitetos. Então o projeto teve que se adaptar ao projeto industrial, eram muito mais baratos esses equipamentos. Quando você olha os croquis dos apartamentos, você percebe fogão, geladeira, todo o mobiliário (ver croquis), isso daqui era um armário de separação da cozinha, e esta daqui era a estrutura em nervura, isso que eu perguntei pro Fernando e ele não lembrava, eu acho que nas últimas partes não há mais nervuras. Pelo processo de fundição de lajes, as nervuras foram eliminadas, então é um detalhe que você tem que ver. Então você vai ver três fases de apartamento: o São Paulo com 1320 que fechavam a primeira quadra, porque o São Paulo era um prédio só, os outros três acabaram fechando a quadra, a segunda eram 1920 apartamentos que fechavam aquela quadra, então cada um deles tem uma alteração no processo construtivo, ou seja, de incrementação tecnológica, no processo descobriu o que dava certo e o que não dava.

\section{Fabiana: Qual era a importância de participar na época desse projeto?}

Mário: Olha, quando eu fui fazer estágio, tive algumas opções, mas primeiro trabalhar com Artigas, com Fábio, com a Giselda, trabalhar nessa equipe eu achava fantástico, imaginei o que eu ia aprender, e de fato eu aprendi muito com esse pessoal todo. E o Paulo Mendes da Rocha, toda vez que falam dele, eu só lembro do Paulo no rodapé dos autores do projeto, mas o Paulo pouco freqüentava a CECAP, o Fábio Penteado era constante. 


\section{Fabiana: 0 que o Paulo Mendes da Rocha contribuiu?}

Mário: Ele trabalhou na equipe que montou o projeto, tinha o Paulo Mendes da Rocha e tinha o Arnaldo Martino também, que é um arquiteto excepcional também. Mas o que importava pra mim na época era trabalhar com a equipe porque o projeto não era tão divulgado, nem tão pouco conhecido. Vagarosamente, os arquitetos foram se apropriando do que estava sendo feito em Guarulhos, um projeto modernista, pioneiro, projeto inclusive que fez 0 Artigas ser premiado no exterior. Você acredita que vinha gente de tudo quanto é lugar do mundo visitar o conjunto, vinha gente do Senegal, daqueles países mais pobres da África.

\section{Fabiana: Eu vi uma foto do começo do conjunto que tinham marcas de garagem na rua, eu não entendi se era pra ser na rua ou sempre foi pensado embaixo dos pilotis?}

Mário: Inicialmente era embaixo dos pilotis. Agora o pessoal foi mudando pra lá foi adaptando o prédio, foi personalizando o prédio. O Fernando foi, achou interessante, mas eu não gostei do que vi, dessa figura final que está o conjunto, o Governo da época deveria ter investido em antenas coletivas, devia ter se preocupado com as telecomunicações, você olha lá, a imagem do conjunto é fria, é cheio de antenas com pontinhas de alumínio, são díspares da imagem do conjunto, que é um projeto limpo, um projeto moderníssimo, cheio de detalhes mais com grande eficiência, hoje eu acho que na verdade esse conjunto deveria ser tombado, deveria ter um investimento do Governo para que algumas coisas fossem arrumadas, arranjadas, reorganizadas, aquele conjunto não está com a mesma beleza plástica que tinha no começo.

\section{Fabiana: Essa divisão em condomínios fechados perdeu o sentido?}

Mário: Perdeu. Tinha a história das freguesias, e as freguesias tinham comércio. A única coisa que eu desenhei e que eu não gostei foi da cadeia, 
mas o conj unto tinha uma concepção muito bonita, e eu acho que se houvesse uma cerca deveria ser em todo o conjunto e não separando as freguesias. Eu acho que nesse caso, o conj unto de Guarulhos deveria ser preservado. Um dos motivos que a gente fez mudanças, é que os armários trincavam muito e foram substituídos por vigas de concreto exatamente por causa disso, quando fez essa mudança mudou também muita coisa da concepção estrutural do projeto, mas continuava sem baldrame. A viga do primeiro andar fazia as vezes do baldrame. Mas a lógica do Artigas tinha razão de ser, ele alegava 0 seguinte, para que serve os baldrames? Para sustentar as paredes que vão em cima, então vai ser sem baldrame. 0 prédio tem que ser o mais leve possível, por isso que não tinha caixa d'água, por isso que não tinha telhado, as paredes eram inicialmente de Pumex² e depois de dry-wall.

\section{Fabiana: E de onde veio essa tecnologia das divisórias?}

Mário: Olha eu não soube ti dizer, na verdade a CECAP era um grande centro de pesquisa, as pessoas estavam envolvidas nesse projeto, a própria indústria trazia materiais. Eu tinha lá um monte de tijolos da Pumex, e não foi a CECAP que se propôs a Pumex, mas sim a Pumex que se propôs a CECAP. Então algumas coisas, como o empreendimento era muito grande, a indústria da construção civil começou a propor as coisas, o caminho se inverteu, daí os materiais eram levados, e o Falcão Bauer fazia análise dos materiais, e aí falava isso serve e isso não serve. Ficou um leva e traz, a indústria trazendo para a CECAP e a CECAP propondo a indústria, num momento isso ficou tão fluente que a gente não sabia mais quem tava propondo o que pra quem.

\footnotetext{
2 Pumex, hoje conhecido de Siporex, é um concreto celular autoclavado (CCA), fabricado no Brasil desde 1957. 0 produto é obtido por processo industrial, com a mistura de cimento, cal, areia e outros materiais silicosos, aos quais se adiciona alumínio em pó. A Autoclavagem - cura a vapor sob pressão de 10 atmosferas e temperatura de 180 - é a fase mais importante do processo.
} 
Texto doado pelo arquiteto Fábio Penteado no dia da entrevista com ele, porém não se sabe a data que foi feito (200?) e nunca foi publicado, mas foi escrito por ele e pela arquiteta Giselda Visconti. Esse texto abaixo apenas reproduz o original.

\section{Conjunto Habitacional Zezinho Magalhães Prado}

\section{Texto: arquiteto Fábio Penteado}

O projeto CECAP - Guarulhos começou em 1966 no momento da posse do Governador de São Paulo, Abreu Sodré, durante a tradicional festa de distribuição de cargos públicos, entre os agregados políticos e afins, quando 0 novo Governador, nomeado pelo Governo militar se deu conta que havia esquecido entre os beneficiados seu velho amigo, Zezinho Magalhães Prado, ex-prefeito e ex-presidente do Clube de Futebol XV de J aú.

Para remediar, Sodré ofereceu ao amigo uma pequena e quase esquecida autarquia, a CECAP - Caixa Estadual de Casas para o Povo - criada em 1949 para desenvolver programas de política habitacional no Estado de São Paulo, que em seus 18 anos de existência havia construído 40 (quarenta) habitações populares, as primeiras no município de Paulo de Faria.

Já como novo presidente da CECAP, Zezinho, como gostava de ser chamado tomou medidas surpreendentes, começando por incorporar à sua "nova CECAP" uma grande área de terreno (2 milhões de m2), antiga propriedade da Caixa Econômica Estadual, localizada no município de Guarulhos - grande São Paulo, nas proximidades do local onde mais tarde seria construído o Aeroporto Internacional da Cumbica, agora André Franco Montoro. 
Impacto maior ele causou ao apresentar proposta para construir naquele terreno, um Conjunto Habitacional, integrando 10 mil unidades de moradia, destinadas à abrigar trabalhadores sindicalizados com renda entre 2 e 6 salários mínimos.

Nas áreas do Governo do Estado a idéia parecia um delírio e a própria Direção do banco Nacional de Habitação - BNH, recém criado, quando procurada, ameaçou não analisar o projeto, duvidando de sua viabilidade.

Zezinho ainda teve o mérito, de convidar o arquiteto Vilanova Artigas para desenvolver os projetos de urbanismo e arquitetura e eu tive a sorte de ser convidado pelo Artigas para ser o seu parceiro e de convidar o Paulo Mendes da Rocha para também assumir conosco a direção dos trabalhos. Foi montado um Escritório Técnico junto à antiga Sede da CECAP na Avenida Brigadeiro Luis Antônio, que começou contando com os arquitetos Giselda Cardoso, Geraldo Vespasiano Puntoni e Ruy Gama, funcionários do extinto Departamentos de Obras Públicas - DOP, e a Giselda aceitou assumir a coordenação do novo escritório.

Com o início das atividades a equipe foi se ampliando com a chegada dos arquitetos Arnaldo Martino e Renato Nunes e os trabalhos eram acompanhados por profissionais ou empresas técnicas especializadas para cada setor de seu desenvolvimento, selecionadas entre as de mais notória capacitação, e contratadas com total liberdade de escolha pelos arquitetos, sem qualquer interferência da Direção da CECAP.

Estes contatos cobriam desde pesquisas sócio-econômicas (Empresa CEMACO - Eugênia Paesani), Pesquisas para Sistemas Educacionais (Mayimi Souza Lima e Celso Lamparelli), Cálculos Estruturais (Escritório Figueiredo Ferraz), Engenharia Hidráulica e Sanitária (PLANIDRO - Engenheiros Azevedo Neto e Álvaro Cunha), Geologia (Eng. Stélvio Ranzini), Orçamentos e Programação de Obra (Escritório L. A. Falcão Bauer e arquiteto Alfredo Paesani), pesquisas de novos equipamentos domiciliares e até estudos de viabilização econômica para implantação de "áreas verdes", que em todo o 
conjunto atingiam mais de $600 \mathrm{mil} \mathrm{m2}$, e custos para sua implantação atingiam valores nunca vistos para projetos de interesse habitacional, chegando a ser considerados inviáveis.

Para os trabalhos de implantação, a serem desenvolvidos em uma só etapa, do projeto completo de urbanismo e serviços complementares, da CECAP - Guarulhos, contamos com o talento e experiência de um velho amigo, o saudoso colega iugoslavo Stipan Dragutin Milicic, parceiro em meus projetos de arquitetura e um dos responsáveis pelas obras de urbanização e implantação de Zagreb, a nova capital da antiga lugoslávia.

Estes trabalhos e pesquisas permanecem como elementos de referência e quase 40 anos depois ainda são temas de estudos em muitas das nossas universidades e obras na mesma escala da CECAP - Guarulhos, se repetem naturalmente em todo 0 país, como documentos afirmadores do pioneirismo e importância de Zezinho Magalhães Prado na história do Urbanismo e da Arquitetura na Política Habitacional no Brasil.

\section{Conjunto Habitacional Zezinho Magalhães Prado}

\section{Texto: arquiteta Maria Giselda Visconti}

Trata-se da implantação de um Plano Habitacional na grande São Paulo, no qual se procurou integrar todos os aspectos da habitação ligados a vida humana, típicas das grandes concentrações urbanas.

O terreno onde está localizado o conjunto, com 180 hectares de área, situado em Guarulhos, tem uma conformação topográfica de relevo pouco acentuado, predominando a várzea do rio Baquirivu, afluente do rio Tietê. 
A natureza do terreno, particularmente das camadas superficiais turfosas, foram dados importantes para a solução urbanística. Todos os edifícios habitacionais estão sobre pilotis, o que resulta melhor condição técnica em função do tipo de solo e maiores vantagens econômicas, liberando a área para circulação de pedestres e jardins.

O projeto foi desenvolvido para 10.560 unidades habitacionais. Tendo em vista o número de habitações, distribuídas em edifícios todos iguais, a estrutura foi calculada em concreto pré-moldado, o que representaria uma economia significativa no consumo total de concreto e também uma redução no prazo de execução da obra.

Entretanto, quando da apresentação do projeto ao Banco nacional da Habitação - BNH, para liberação de financiamento, foi aprovada a construção de somente 480 unidades na primeira etapa. Esta decisão inviabilizou a execução da estrutura de concreto pré-moldado, tendo sido recalculada a estrutura para construção por processo convencional.

Grandes avanços tecnológicos foram atingidos durante a implantação das várias etapas de construção tanto no sistema construtivo como no desenvolvimento de materiais.

Na terceira etapa da construção foi possível introduzir formas metálicas para a execução da estrutura, permitindo uma economia substancial além do que o concreto aparente apresentava melhor qualidade.

O piso, desenvolvido especialmente para o projeto, é constituído de mantas vinílicas, tipo de piso não existente no Brasil naquela época, anos 70 do século passado. As mantas estendidas no apartamento como um todo, permitiam flexibilidade de adaptações segundo os hábitos e tamanho da família, com simples remoção ou recolocação das divisórias, que são de gesso.

$\mathrm{Na}$ terceira e quarta etapa de obras foram instalados os caixilhos de alumínio, em substituição aos de ferro das duas primeiras fases. Sendo os caixilhos modulados e em grande quantidade, uma industria nacional 
viabilizou, juntamente com o Escritório Técnico da CECAP, um projeto para os novos caixilhos economicamente viáveis.

Outro ponto marcante do projeto foi à introdução "da cor" nas fachadas dos edifícios habitacionais.

Fábio já havia proposto, no início da década de 60, composições cromática em dois de seus projetos de conjuntos habitacionais, "Bairro do Limão" em São Paulo, e a "Cidade dos Doqueiros" em Santos / S.P., projetos que não se concretizaram, mas representaram importante referência para a CECAP - Guarulhos, quando foram estudadas cores básicas para cada prédio, solução que valorizou sobremaneira, a paisagem do conjunto.

Nas várias etapas de construção, aproximadamente $50 \%$ do projeto foi implantado. Além das habitações foram construídos Centro Comercial, duas escolas, Centro de Saúde e Centro Comunitário.

\section{INFRA-ESTRUTUTRA}

Para abastecimento de água, foi implantado um único reservatório na parte mais alta do terreno e uma rede de distribuição dimensionada para alimentação direta aos pontos de consumo. Há sensível economia na instalação predial, pois a rede correspondente é de menor custo e os reservatórios em cada edifício não existem.

Quando a energia calorífica, foi instalada uma central de abastecimento de gás e rede de distribuição, solução que eliminou a utilização de botijões individuais e seu transporte pelas escadas, além da presença de um "objeto estranho" e as vezes perigoso na área de trabalho da casa. 
Desde o inicia da pesquisa de mestrado em março de 2004 foram feitas várias visitas ao Conj unto Habitacional Zezinho Magalhães Prado, abaixo estarão listados quatro acervos fotográficos, sendo usados ou não no corpo da dissertação. Em algumas visitas não listadas tivemos problemas de mau tempo ou outros tipos de imprevistos.

\section{1a Visita:}

Data: 06/ 09/2004 - segunda-feira.

Objetivo: Fotos gerais do Conj unto habitacional Zezinho Magalhães Prado.

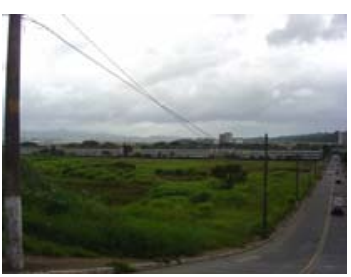

foto_01

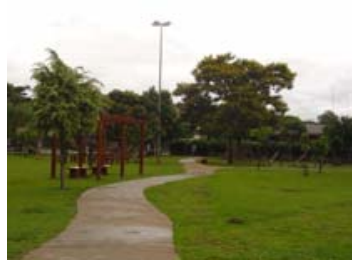

foto $\_5$

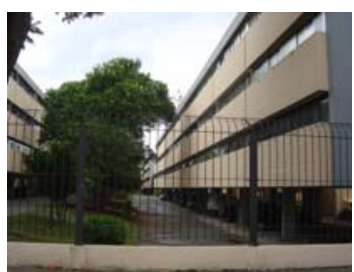

foto 09

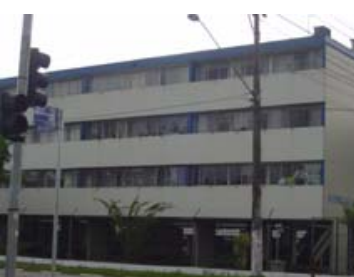

foto $\_2$

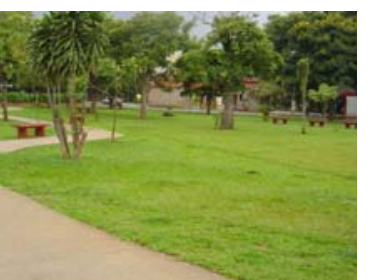

foto_06

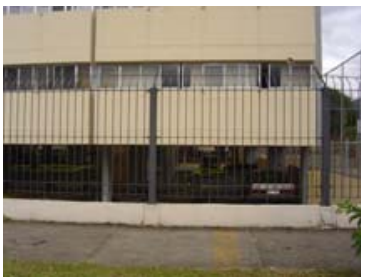

foto $\_10$

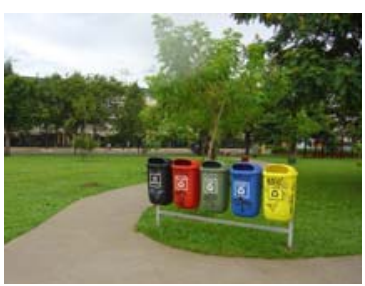

foto 03

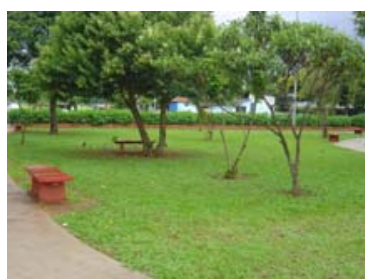

foto_07

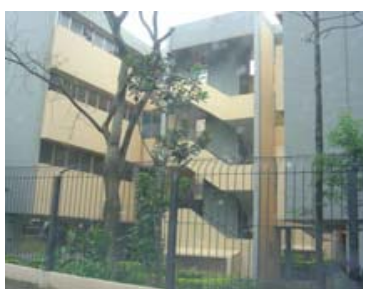

foto_11

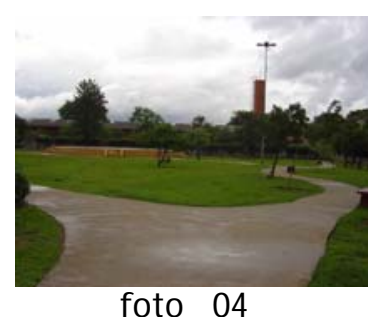

foto _04

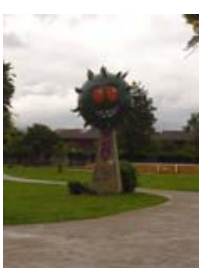

foto _08

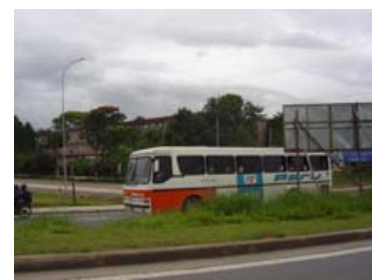

foto 12 


\section{2a Visita:}

Data: 11/ 03/2005 - sexta-feira.

Objetivo: Fotos internas do Condomínio Espírito Santo, inclusive de uma unidade, pertencente à terceira etapa de construção do Conjunto habitacional Zezinho Magalhães Prado.

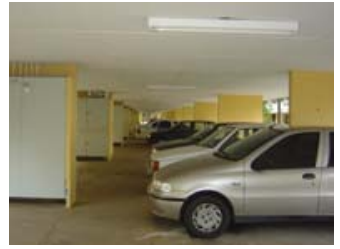

foto_ 13

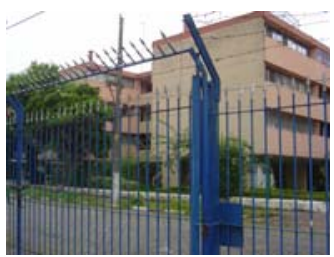

foto 17

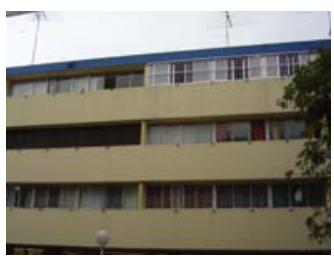

foto_21

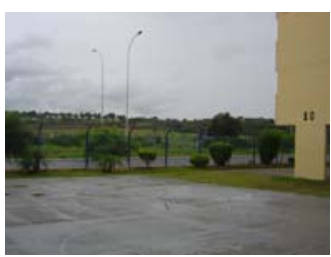

foto 25

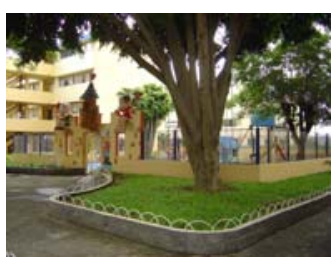

foto_29

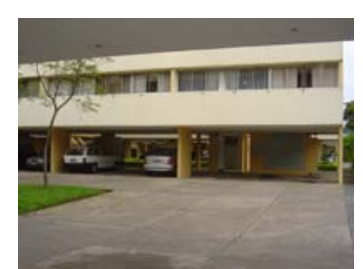

foto_14

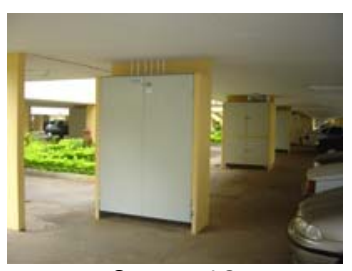

foto_18

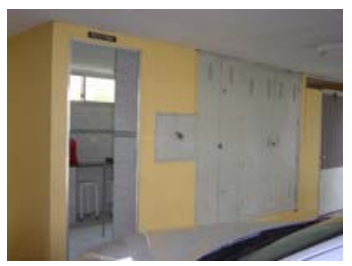

foto 22

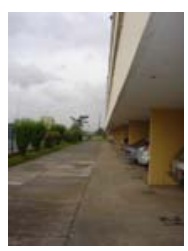

foto _ 26

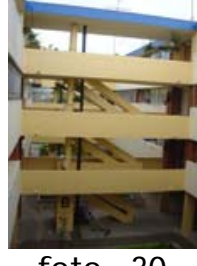

foto _30

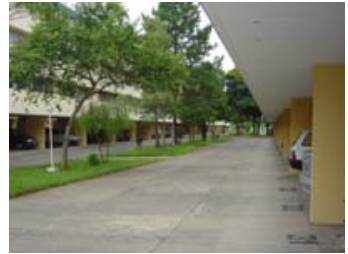

foto _15

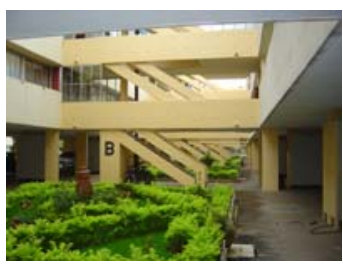

foto _19

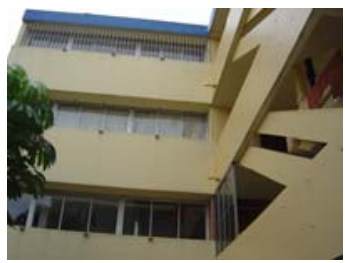

foto _23

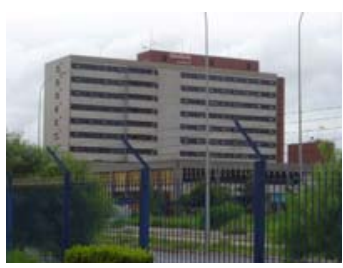

foto_27

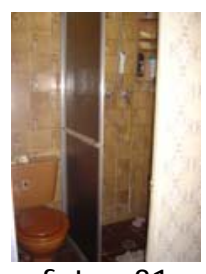

foto 31

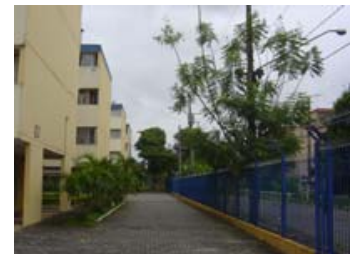

foto_16

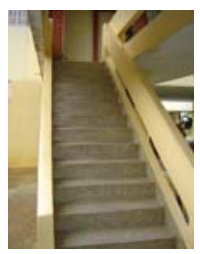

foto 20
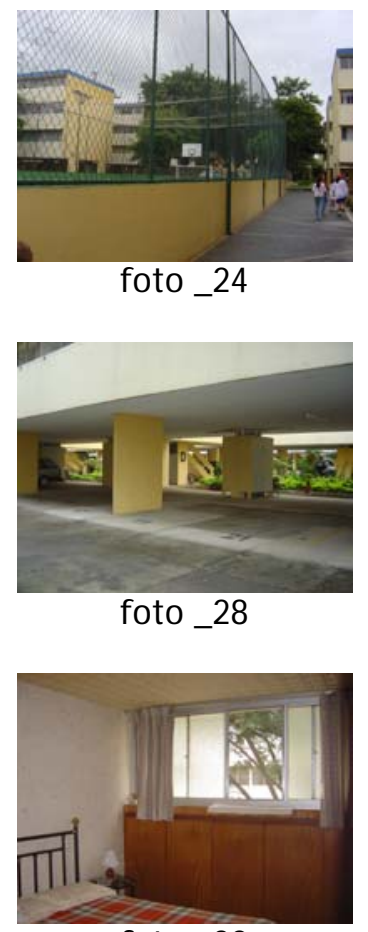

foto 32 


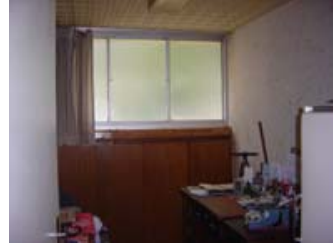

foto _33

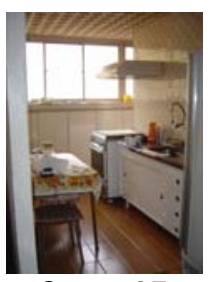

foto 37
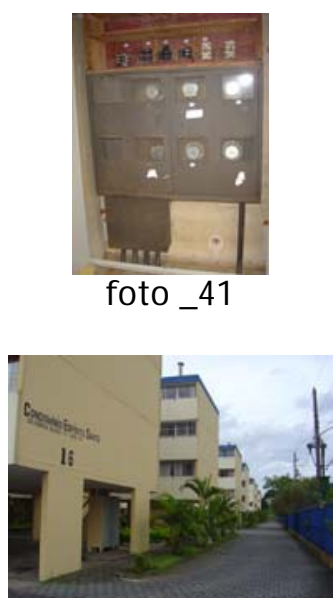

foto 45

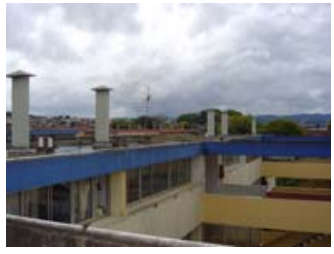

foto 49
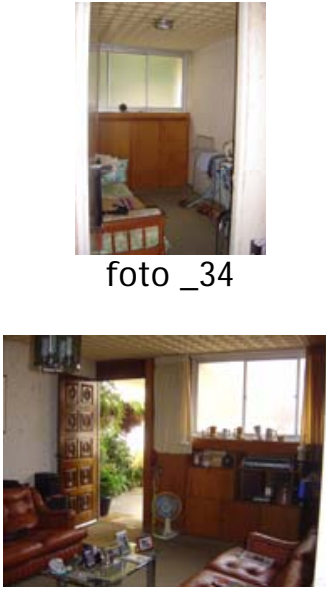

foto _38
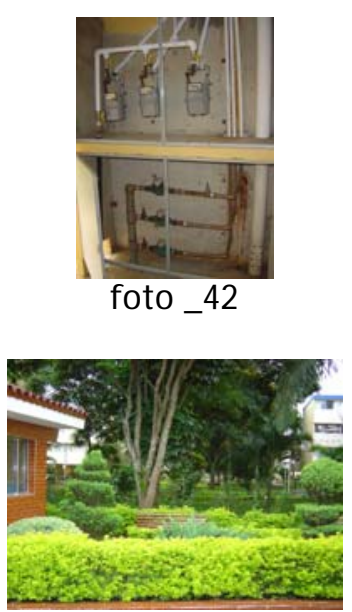

foto 46

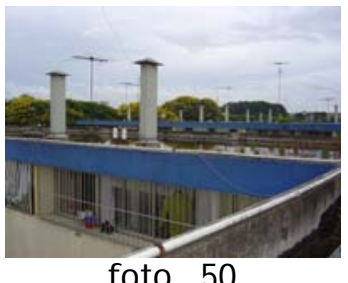

foto_50
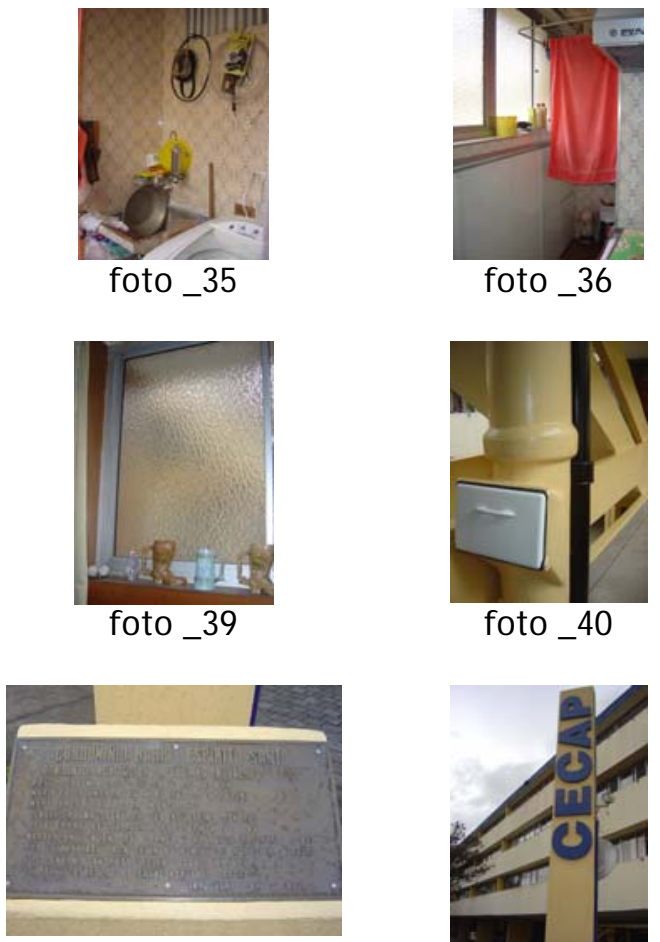

foto $\_43$

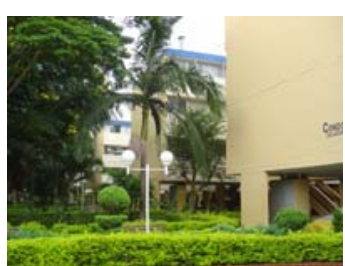

foto 47

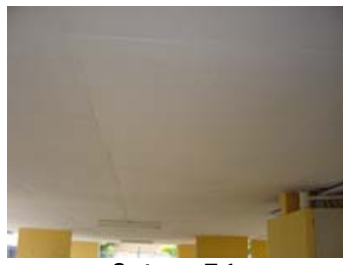

foto 51
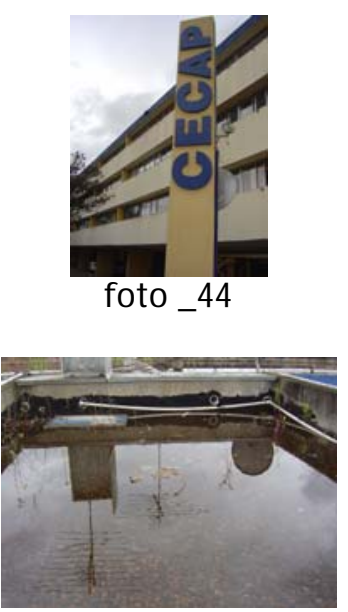

foto 48

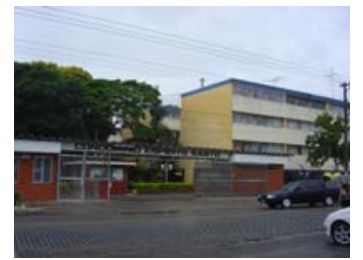

foto 52 


\section{3a Visita:}

Data: 02/ 12/ 2006 - sábado.

Objetivo: Fotos dos equipamentos coletivos do Conjunto Habitacional Zezinho Magalhães Prado, rotatórias, avenidas e rodovias próximas e vista geral com imagem do aeroporto.

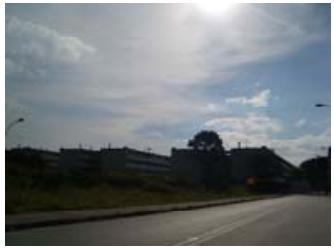

foto $\_53$

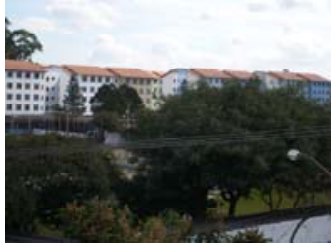

foto_57

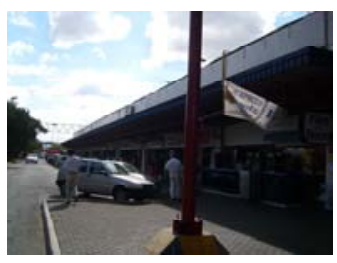

foto 61

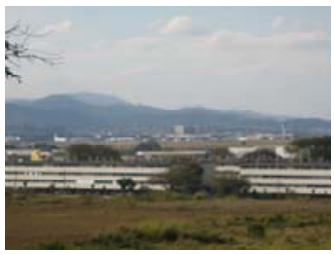

foto 65

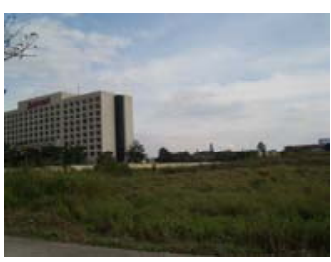

foto 69

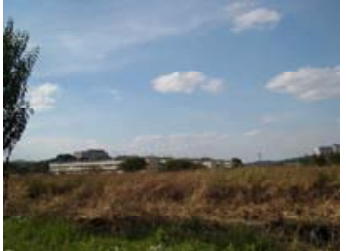

foto $\_54$

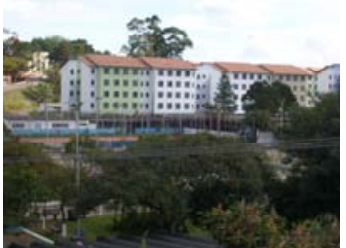

foto_58

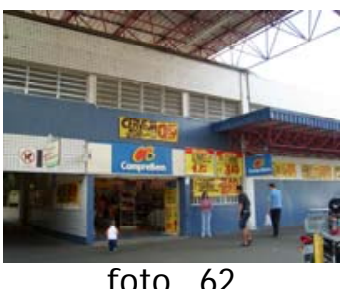

foto 62

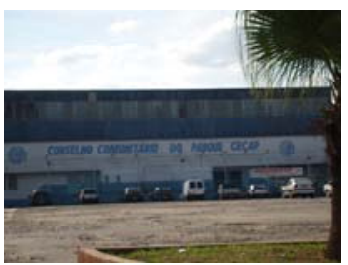

foto 66

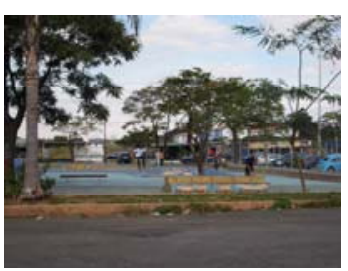

foto _ 70
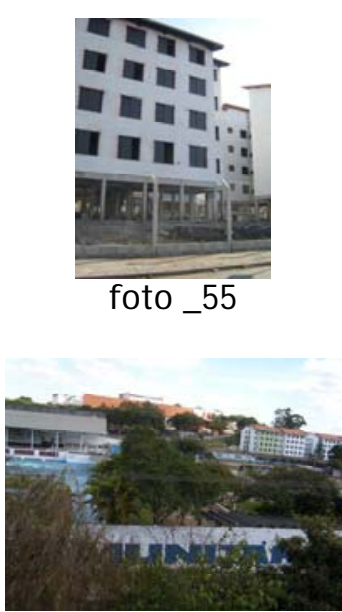

foto_59

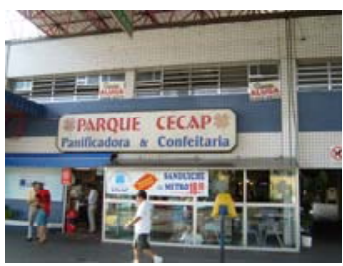

foto 63

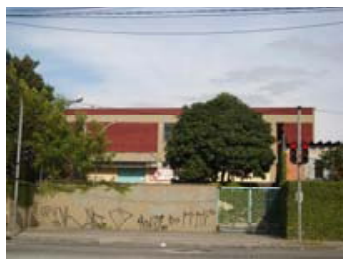

foto _67

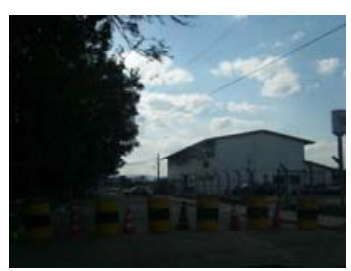

foto 71

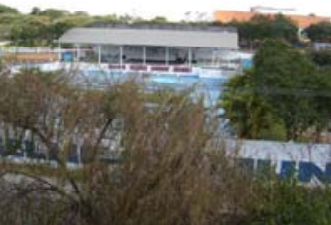

foto _ 56

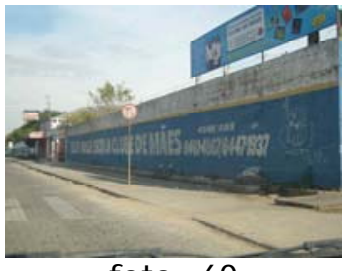

foto 60
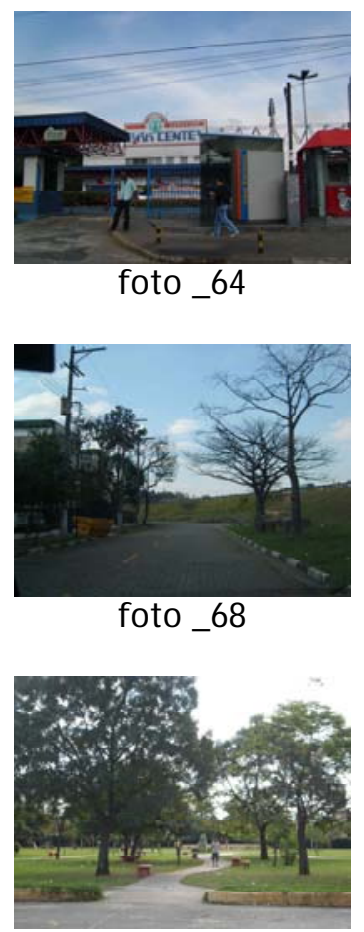

foto 72 


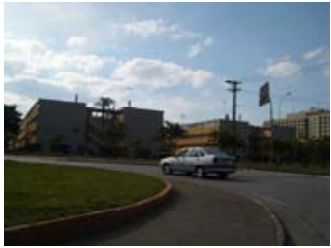

foto_73

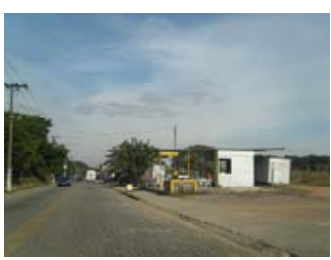

foto 77

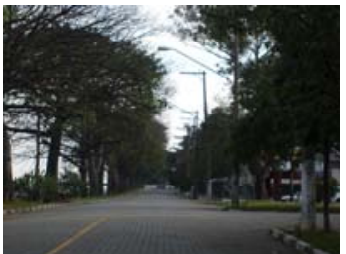

foto 74

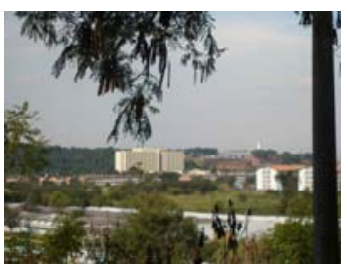

foto 78

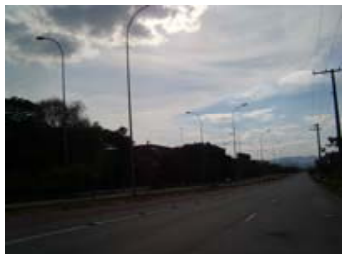

foto_75

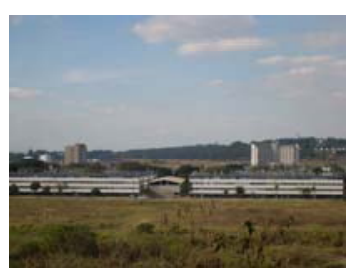

foto_79

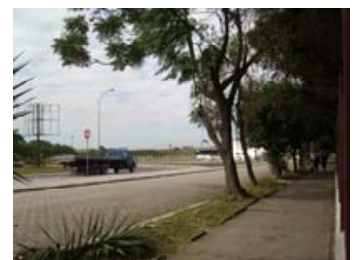

foto_76

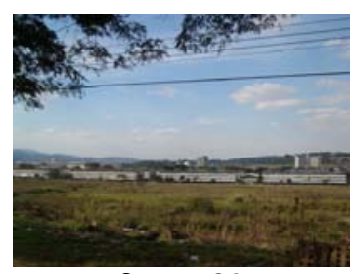

foto 80

\section{4a Visita:}

Data: 24/ 06/ 2007 - domingo.

Objetivo: Fotos das diferentes fases da construção do Conjunto Habitacional Zezinho Magalhães Prado, acompanhada pela arquiteta Solimar Isaac Mendes, moradora do Condomínio São Paulo.

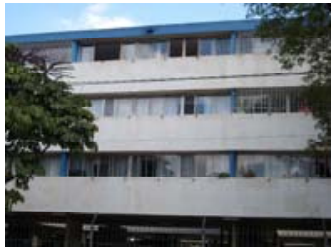

foto _81

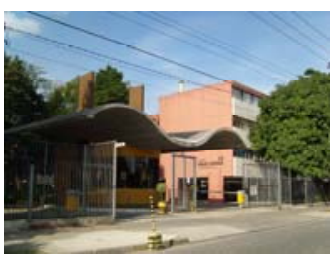

foto _ 85

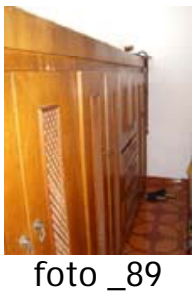

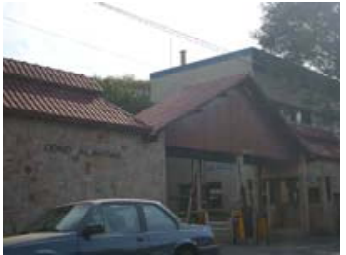

foto 82

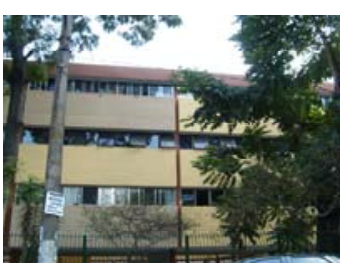

foto _ 86

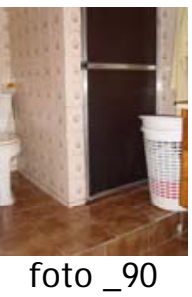

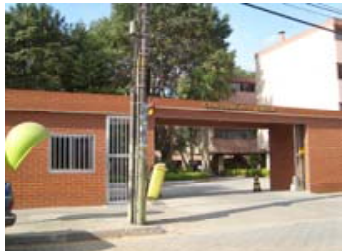

foto 83

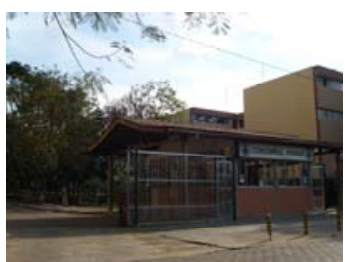

foto 87

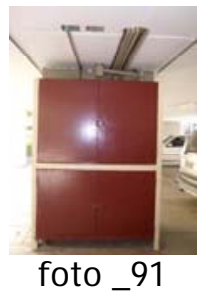

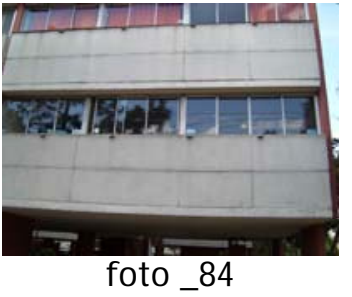

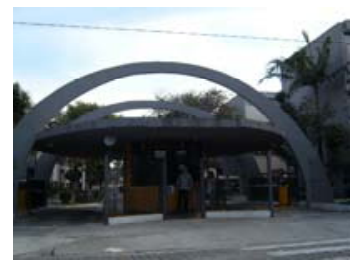

foto _88

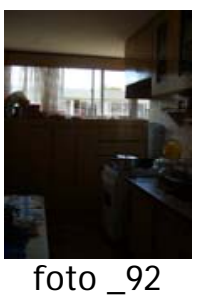




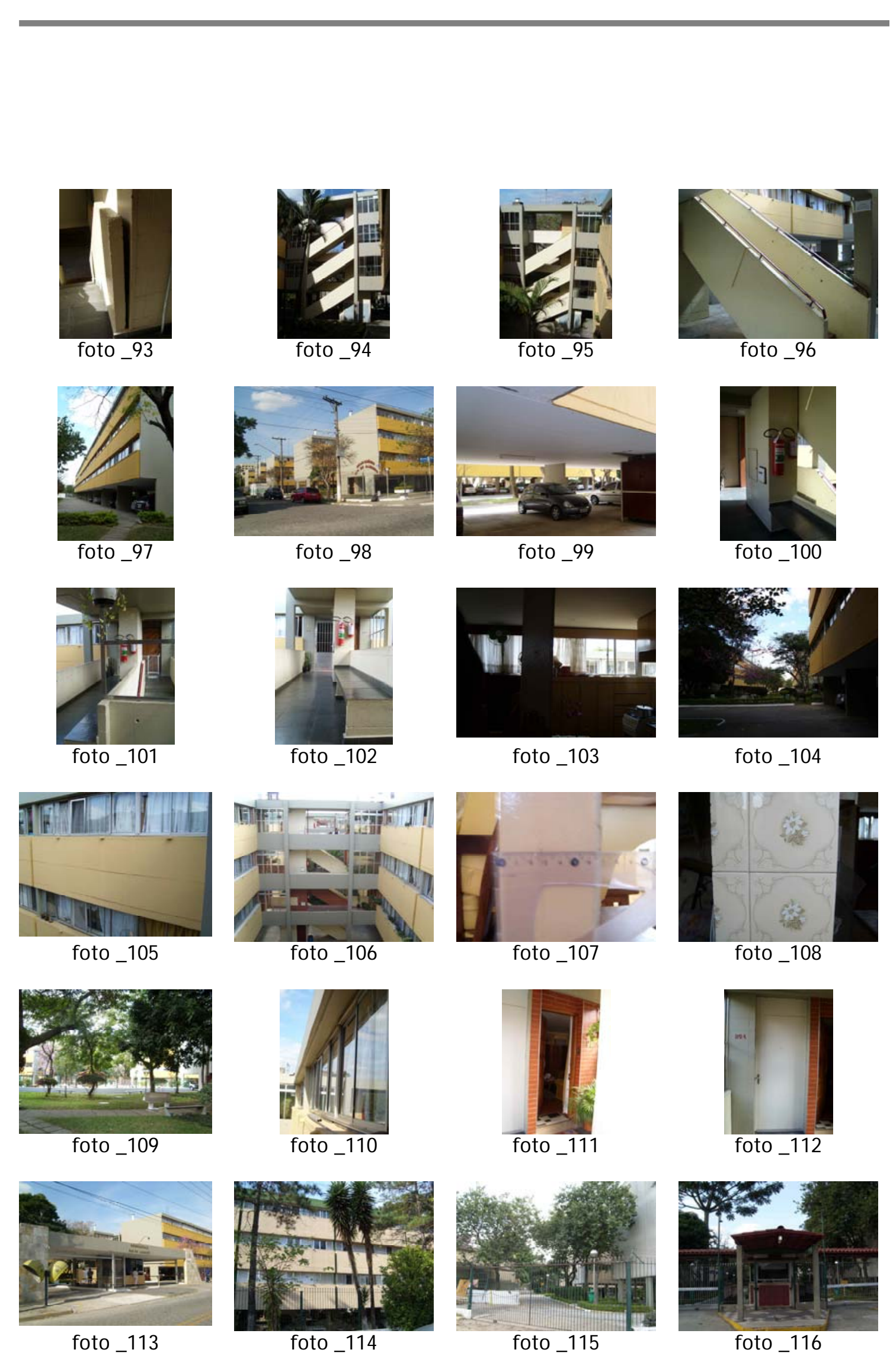




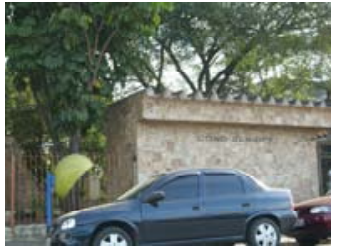

foto_ 117
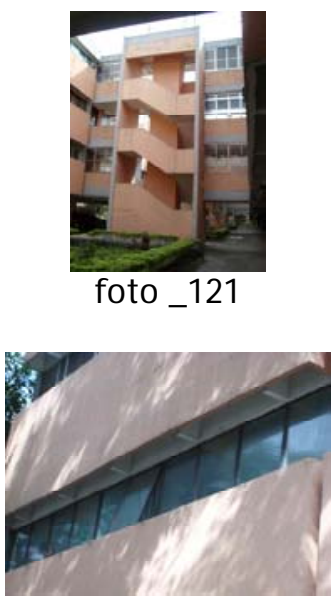

foto _ 125

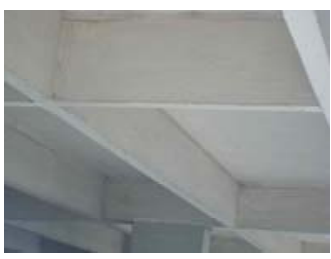

foto _ 129

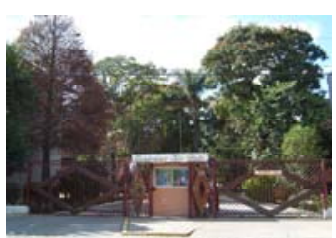

foto 133

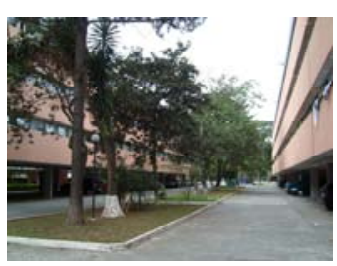

foto_ 137

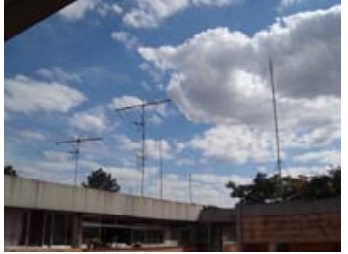

foto _118
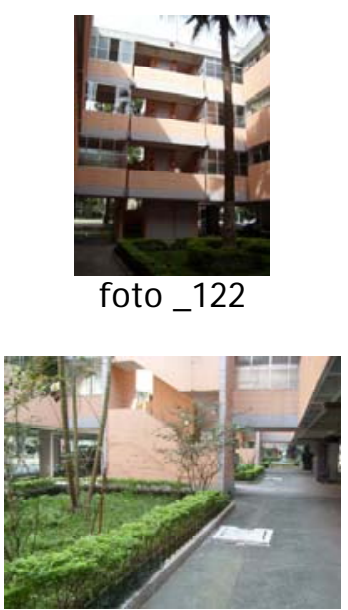

foto _126

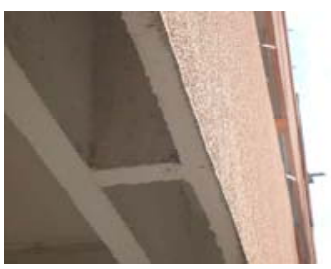

foto 130
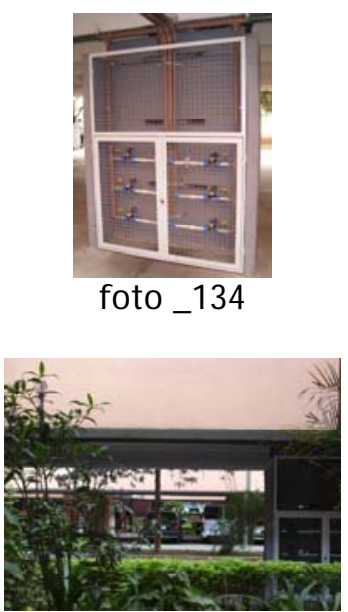

foto _138
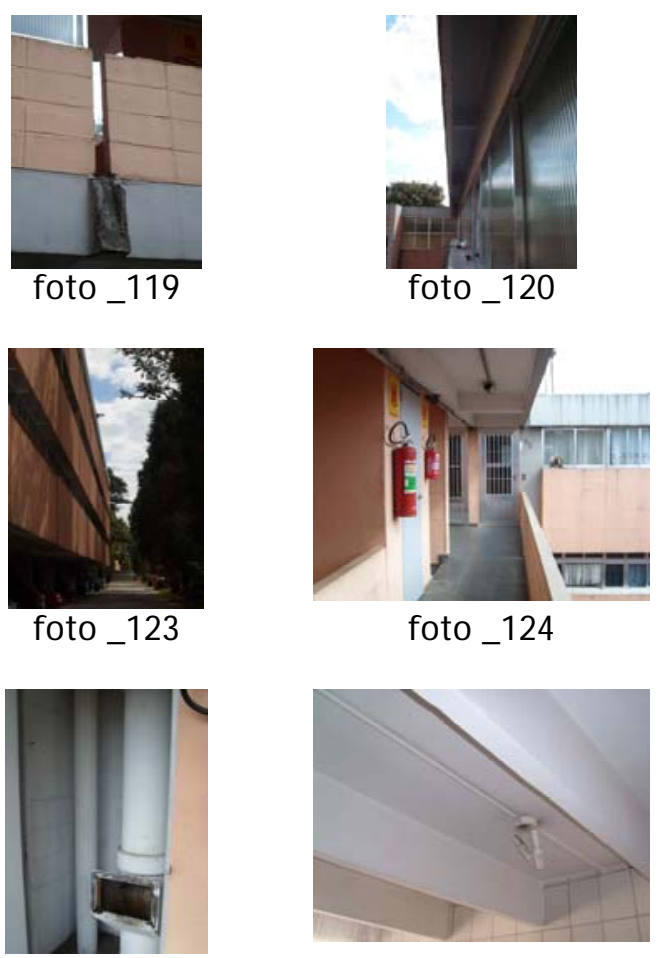

foto_ 128
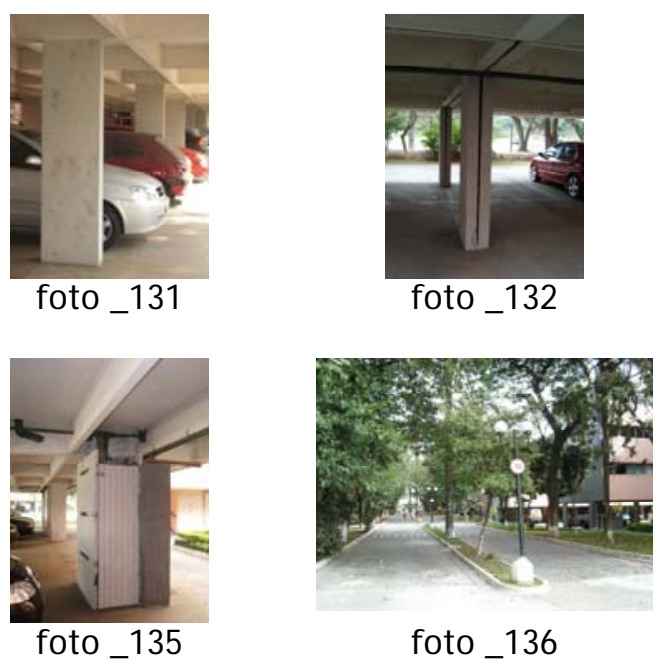

foto_136 


\section{ANEXO 8}

Abaixo estão anexadas plantas do Conjunto habitacional Zezinho Magalhães Prado, adquiridas junto ao arquivo da CDHU (plantas 1 a 19) e biblioteca da FAU (plantas 20 a 25), que está digitalizando o acervo do arquiteto Vilanova Artigas, que se encontrava na Fundação Artigas.

As plantas serão mostradas em tamanho reduzido para simples apresentação do material pesquisado e adquirido, para melhor resolução estará anexado ao final do trabalho um cd com todas as plantas digitalizadas.

DESCRIÇÃO

PÁGINA

\begin{tabular}{|c|c|c|c|}
\hline PLANTA 1 & & Proj eto Arquitetura-6M-25/ 09/ 1970. & LXVII \\
\hline PLANTA 2 & 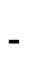 & Projeto Arquitetura-4M-20/ 07/ 1970 e 18/ 02/ 1972. & LXVIII \\
\hline PLANTA 3 & - & Projeto Arquitetura-5M-07/ 1975 e 15/ 09/ 1975. & LXIX \\
\hline PLANTA 4 & - & Projeto Arquitetura-3-23/ 11/ 1976. & LXX \\
\hline PLANTA 5 & - & Proj eto Arquitetura-9-18/ 03/ 1972. & LXXI \\
\hline PLANTA 6 & - & Projeto Edificação - ARQ. 01 - 09/ 10/ 1978. & LXXII \\
\hline PLANTA 7 & - & Projeto Edificação - ARQ. 02 - 11/ 10/ 1978. & LXXIII \\
\hline PLANTA 8 & 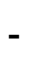 & Projeto Edificação - ARQ. 03 - 11/ 10/ 1978. & LXXIV \\
\hline PLANTA 9 & - & Projeto Edificação - ARQ. 04 - 11/ 10/ 1978. & LXXV \\
\hline PLANTA 10 & - & Projeto Edificação - ARQ. 05 - 11/ 10/ 1978. & LXXVI \\
\hline PLANTA 11 & - & Projeto Edificação - ARQ. 06 - 11/ 10/ 1978. & LXXVII \\
\hline PLANTA 12 & 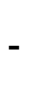 & Projeto Edificação - ARQ. 07 - 11/ 10/ 1978. & LXXVIII \\
\hline PLANTA 13 & & Projeto Edificação - ARQ. 08 - 11/ 10/ 1978. & LXXIX \\
\hline
\end{tabular}


PÁGINA

PLANTA 14 - Projeto Concreto - 20 - 08/ 02/ 1971.

LXXX

PLANTA 15 - Projeto Edificação - EST. 01 - 19/ 10/ 1978.

LXXXI

PLANTA 16 - Proj eto Edificação - EST. 08 - 19/ 10/ 1978.

LXXXII

PLANTA 17 - Projeto Edificação - EST. 16 - 19/ 10/ 1978.

LXXXIII

PLANTA 18 - Projeto Edificação - HID/ GAS. 09 - 19/ 10/ $1978 . \quad$ LXXXIV

PLANTA 19 - Projeto Edificação - HID. 10 - 19/ 10/ $1978 . \quad$ LXXXV

PLANTA 20 - Projeto Arquitetura-2-21/ 02/ $1972 . \quad$ LXXXVI

PLANTA 21 - Proj eto Arquitetura-7M-25/ 09/ 1970 e 21/ 02/ 1972. LXXXVII

PLANTA 22 - Projeto Arquitetura-8A-s/ data. LXXXVIII

PLANTA 23 - Io Estudo Comércio Freguesia - 12/ $72 . \quad$ LXXXIX

PLANTA 24 - Projeto Clube-s/ data. XC

PLANTA 25 - Projeto Ginásio de Esportes-s/ data. XCl

PLANTA 26 - Projeto Urbanismo-URB1-julho/ $1990 . \quad$ XCII

PLANTA 27 - Projeto Urbanismo-URB1-julho/ $1995 . \quad$ XCIII 
PLANTA 1

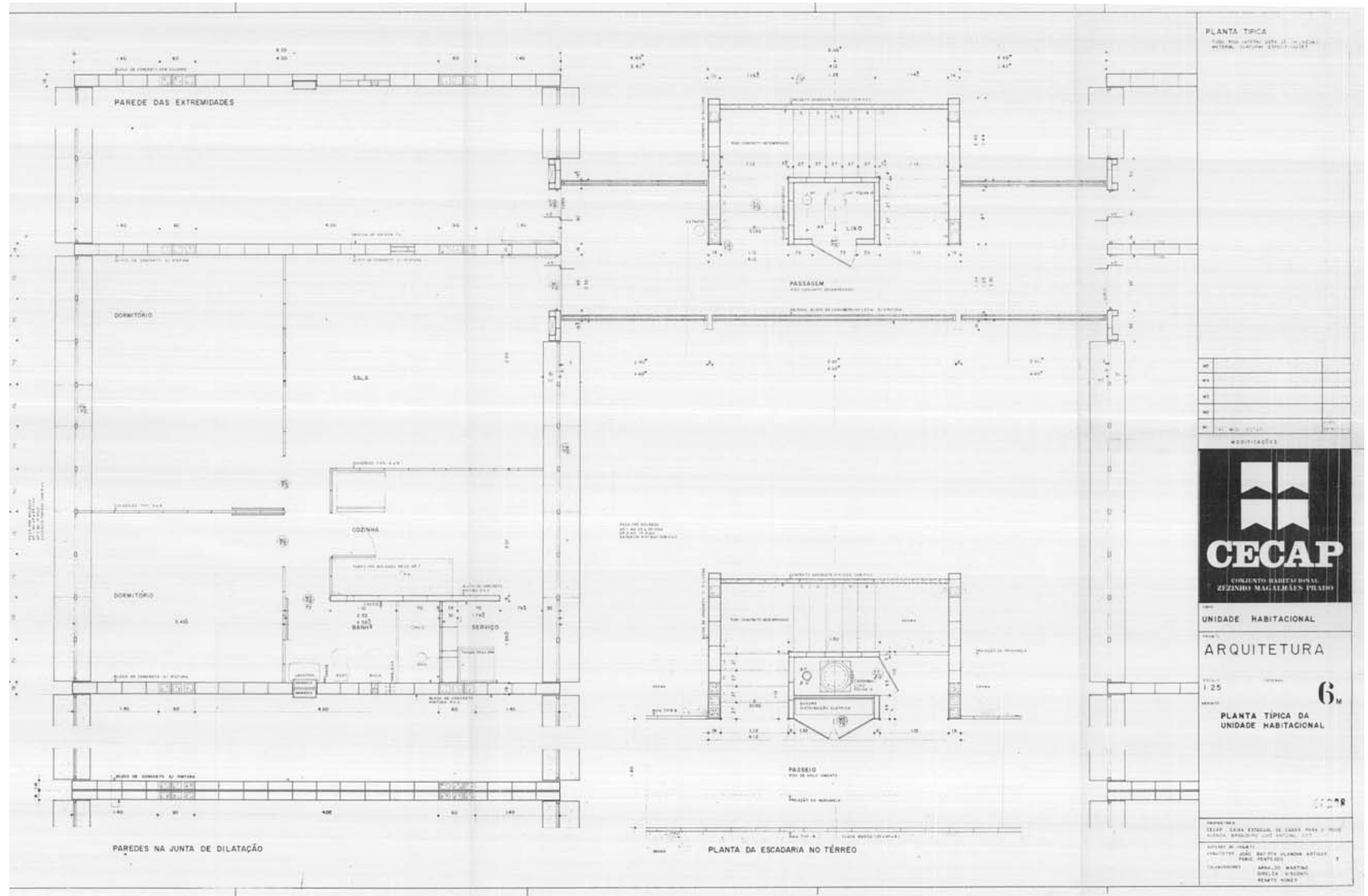


PLANTA 2

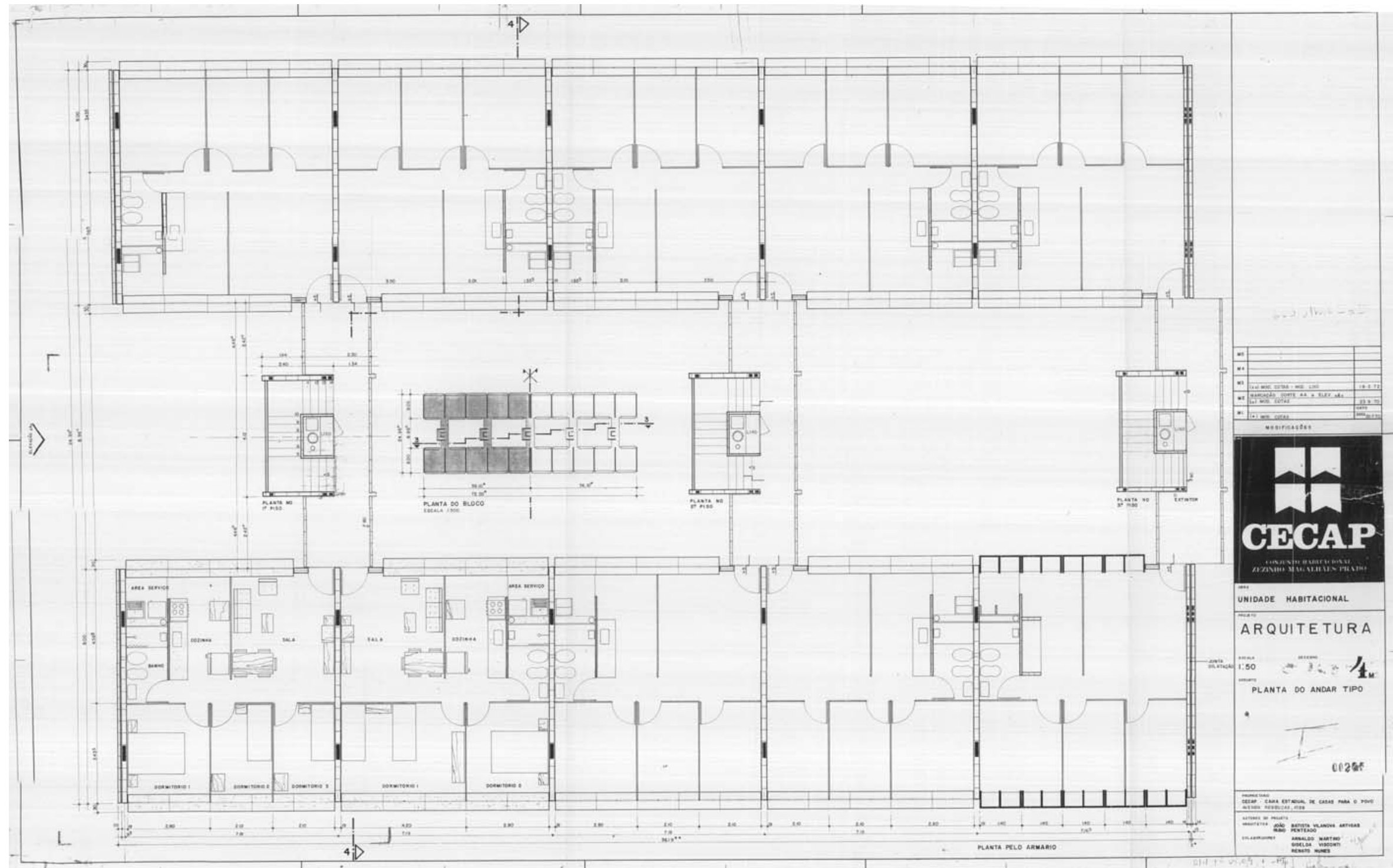




\section{PLANTA 3}

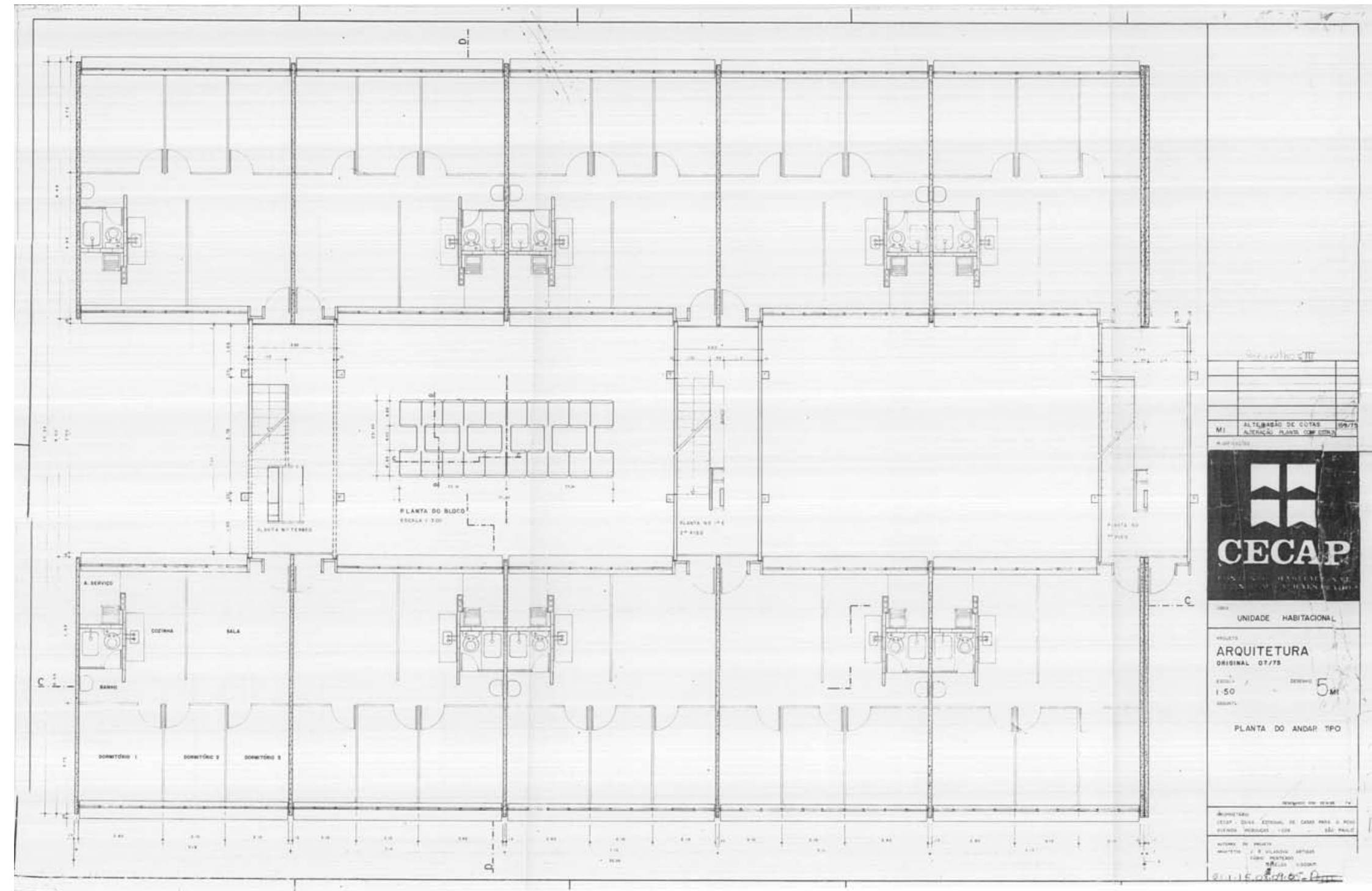




\section{PLANTA 4}

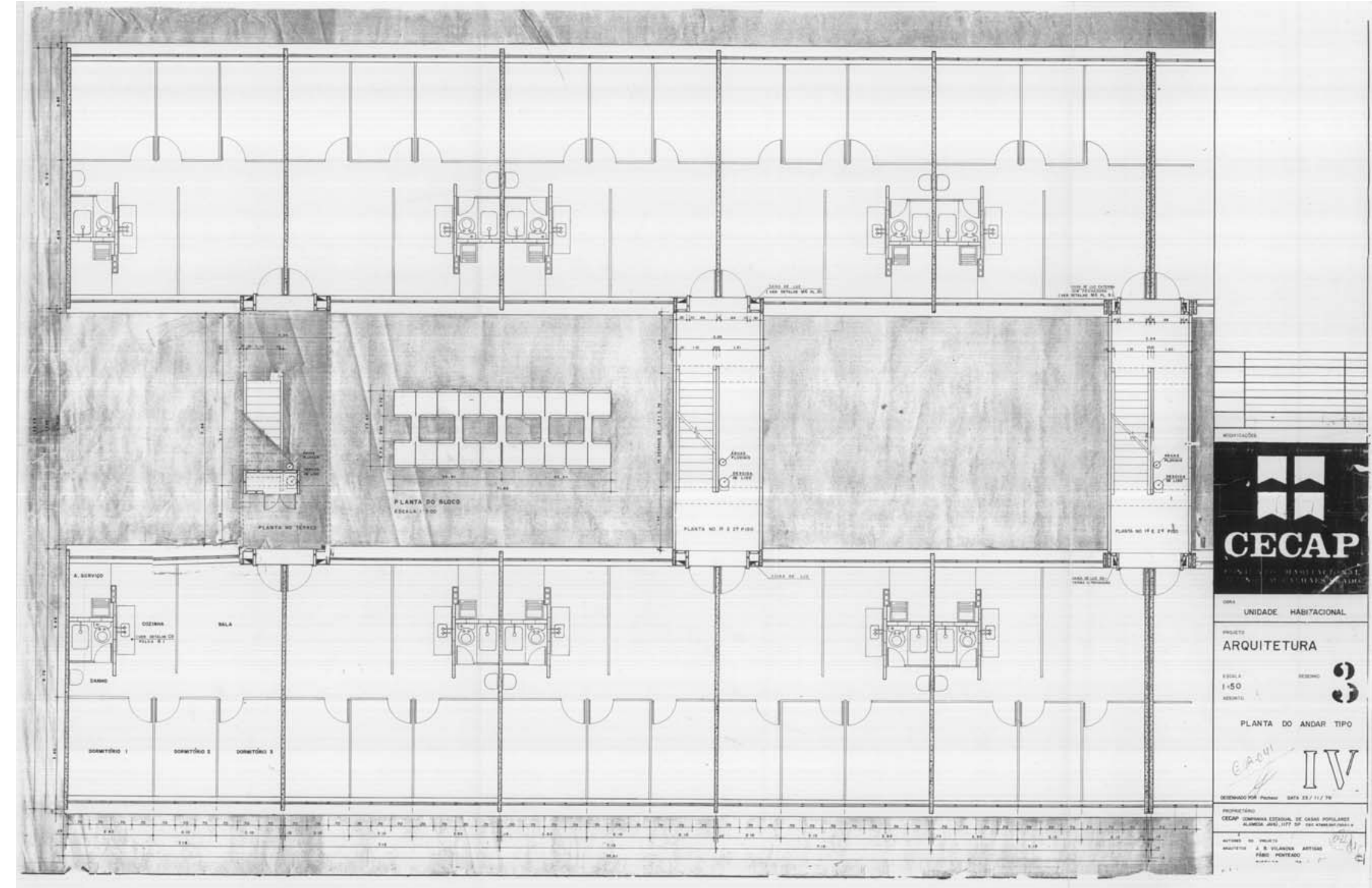




\section{PLANTA 5}

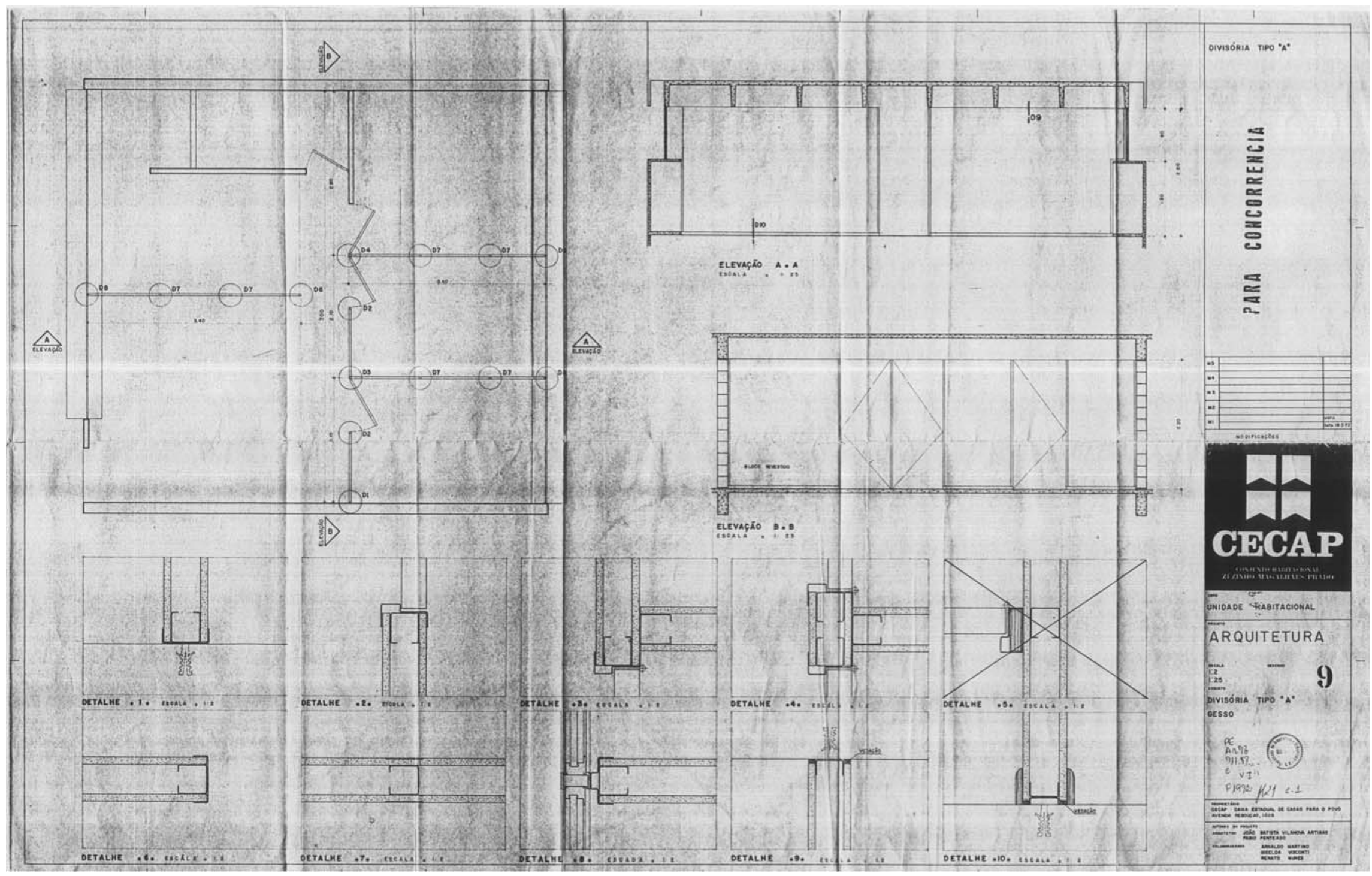


PLANTA 6

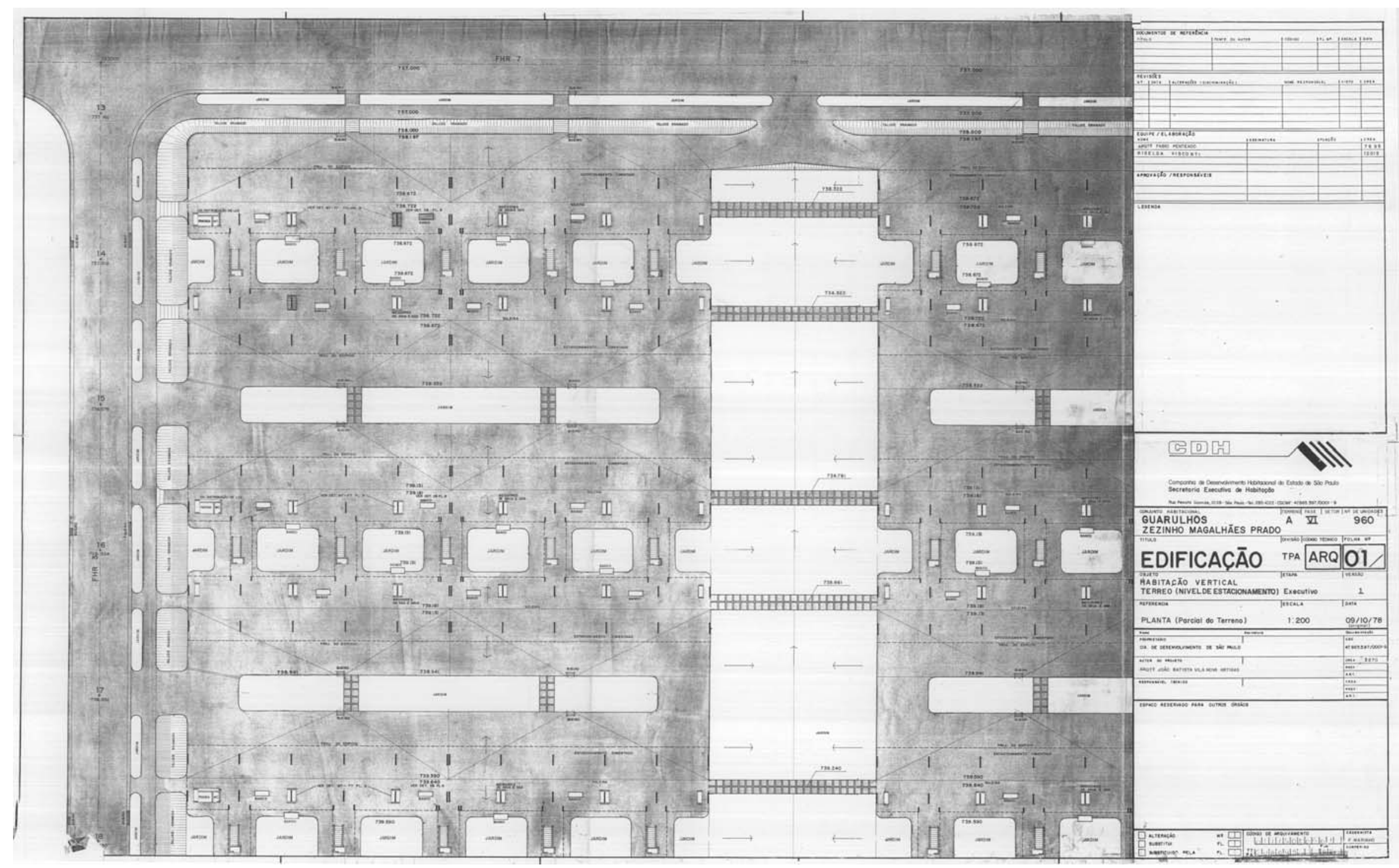


PLANTA 7

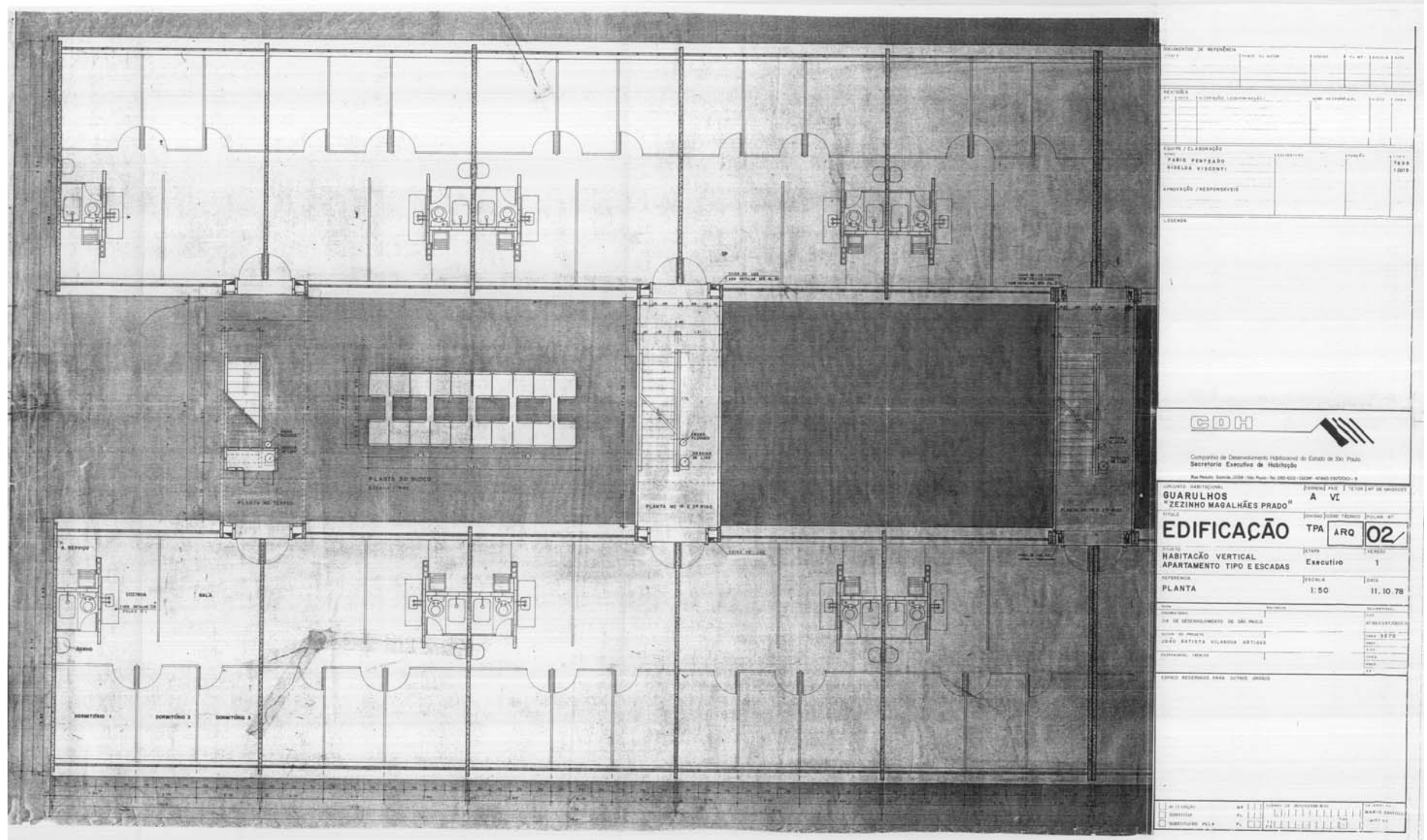


LXXV PLANTA 8
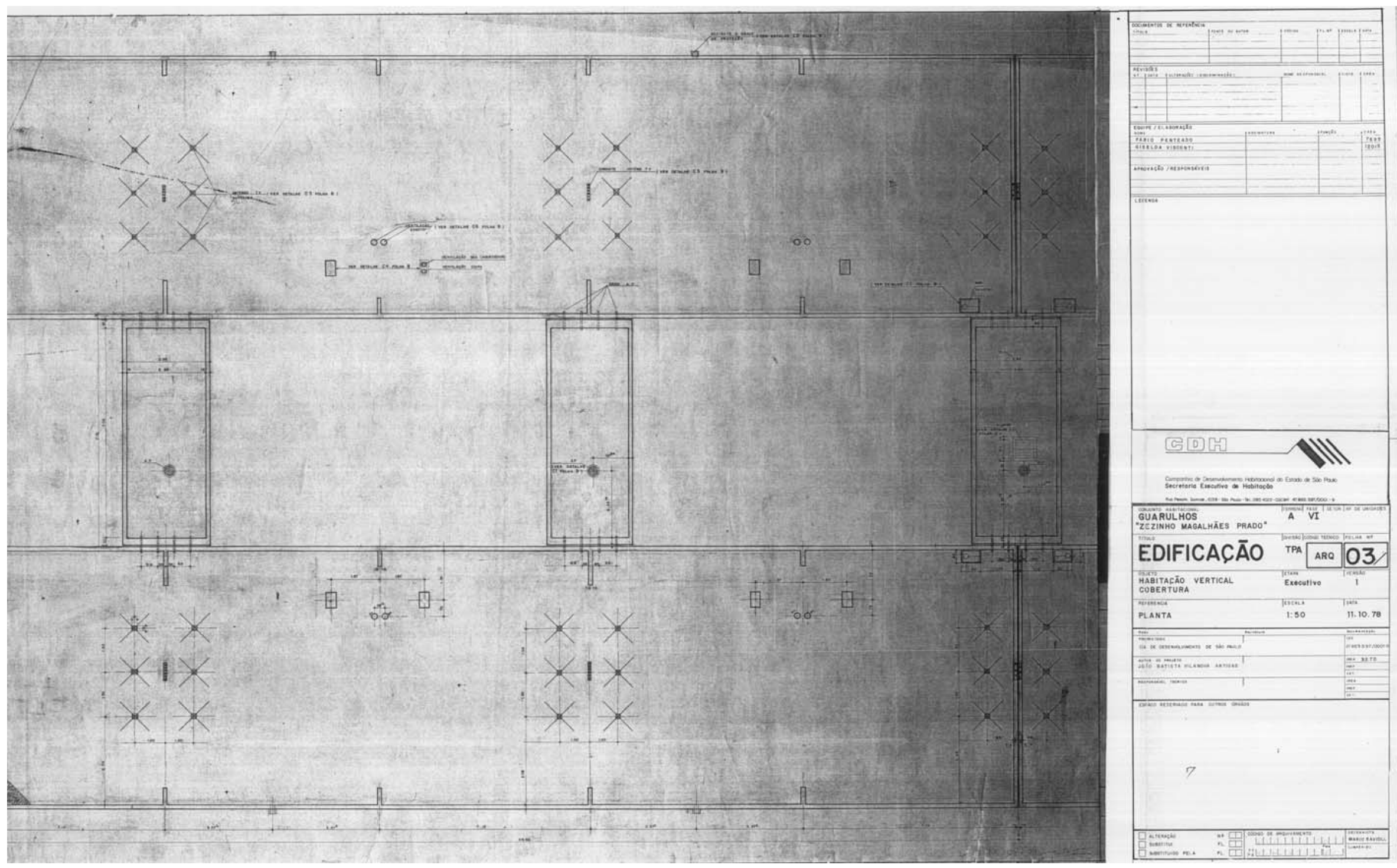
PLANTA 9

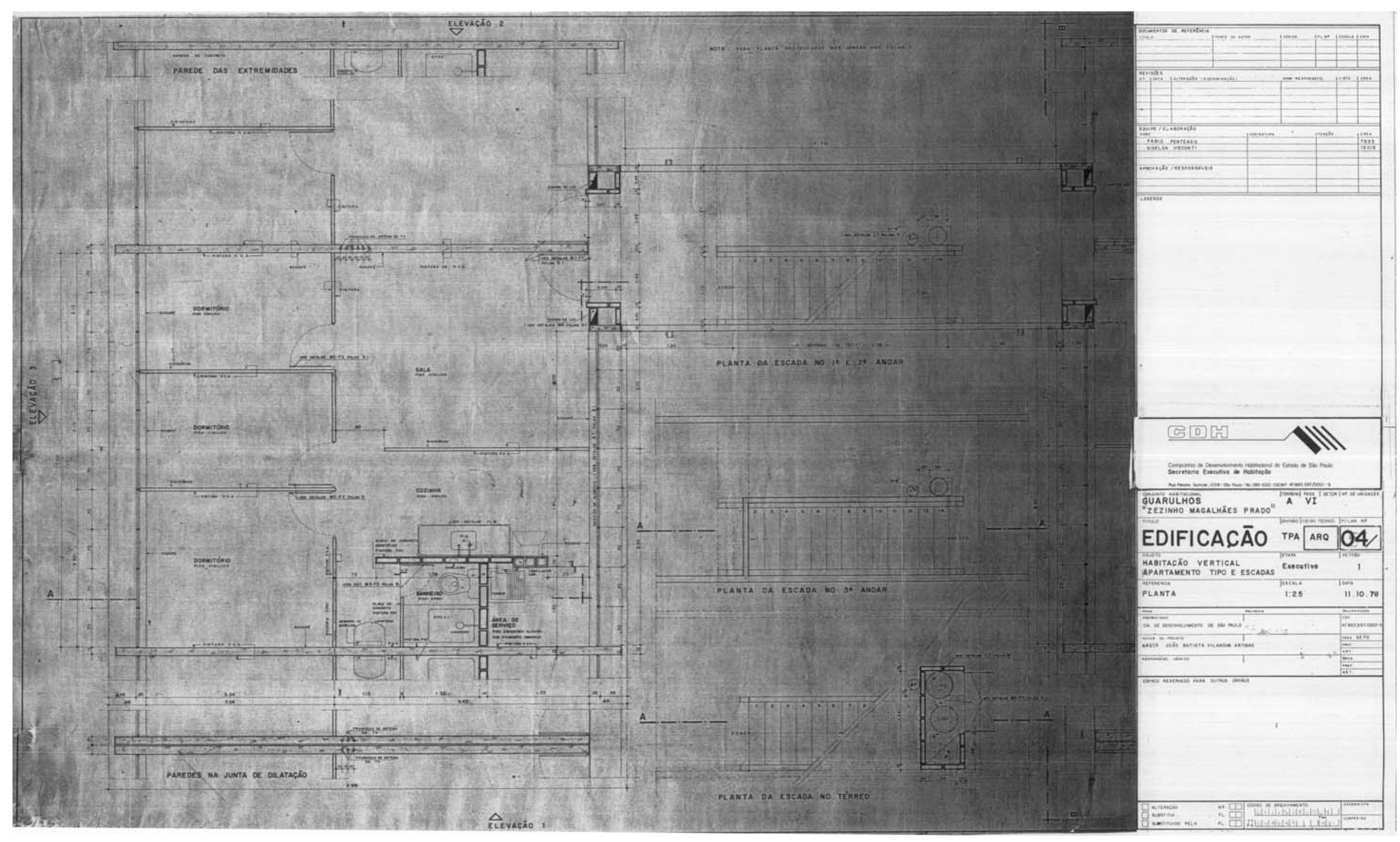


PLANTA 10

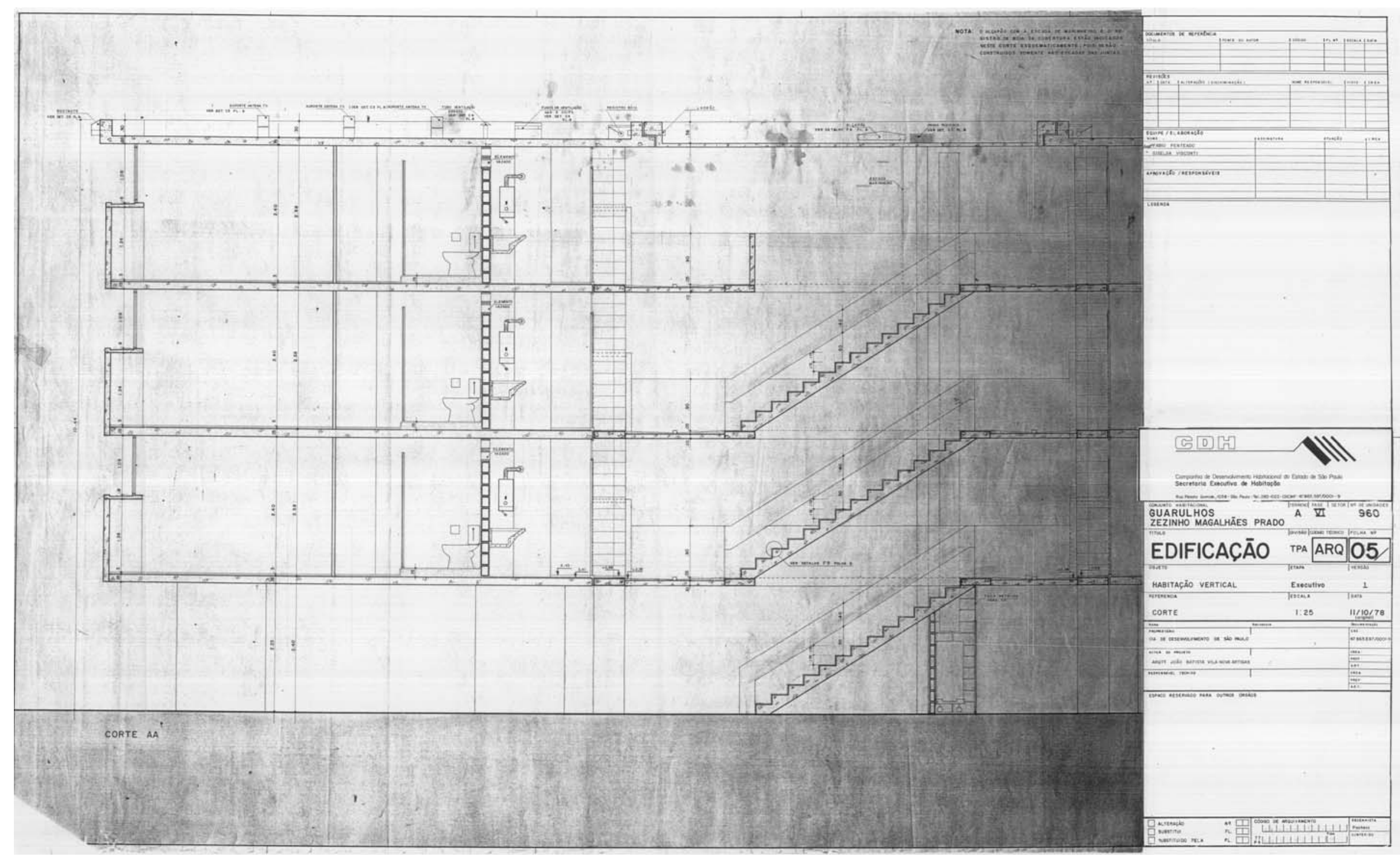


PLANTA 11
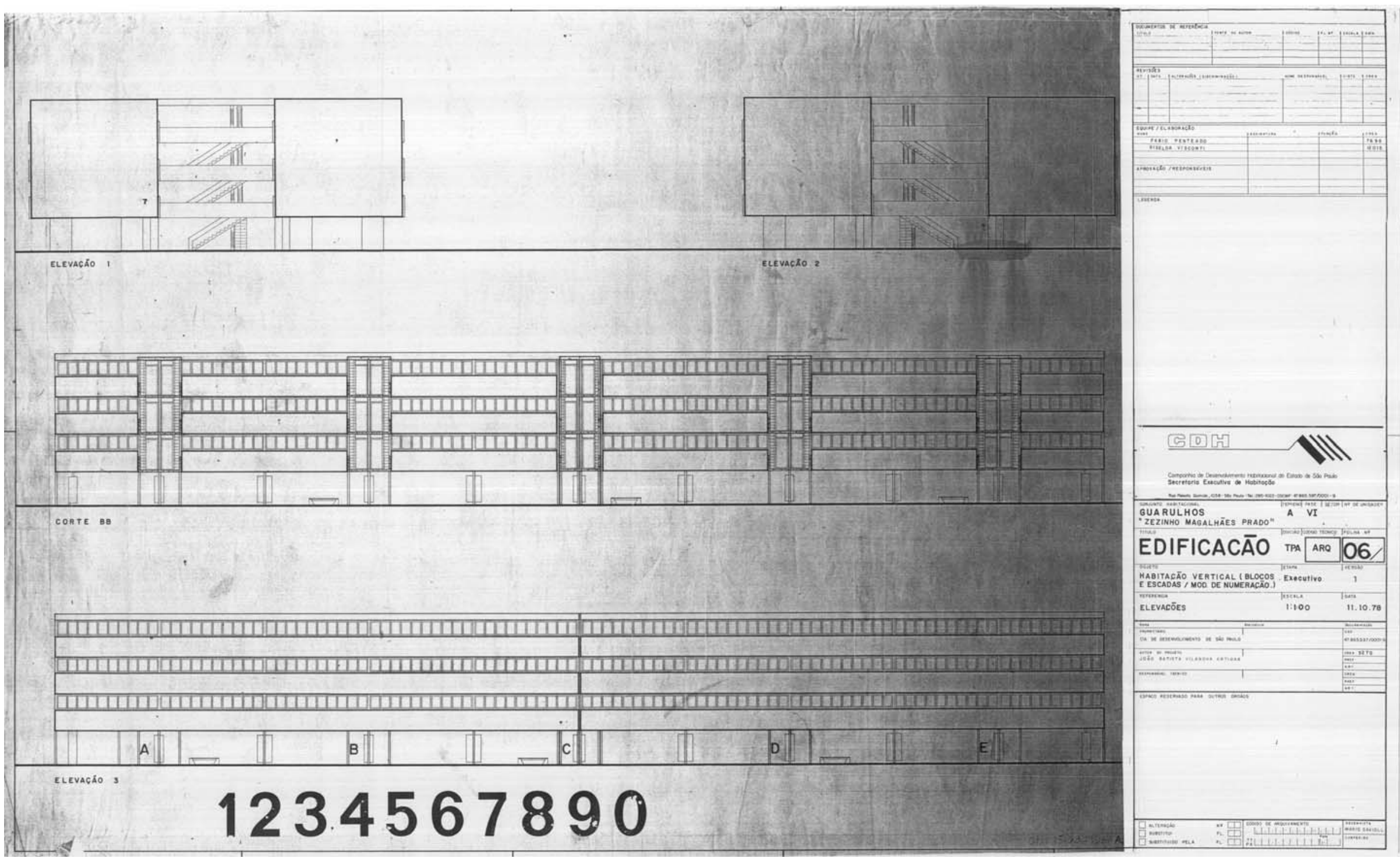
LXXVIII PLANTA 12

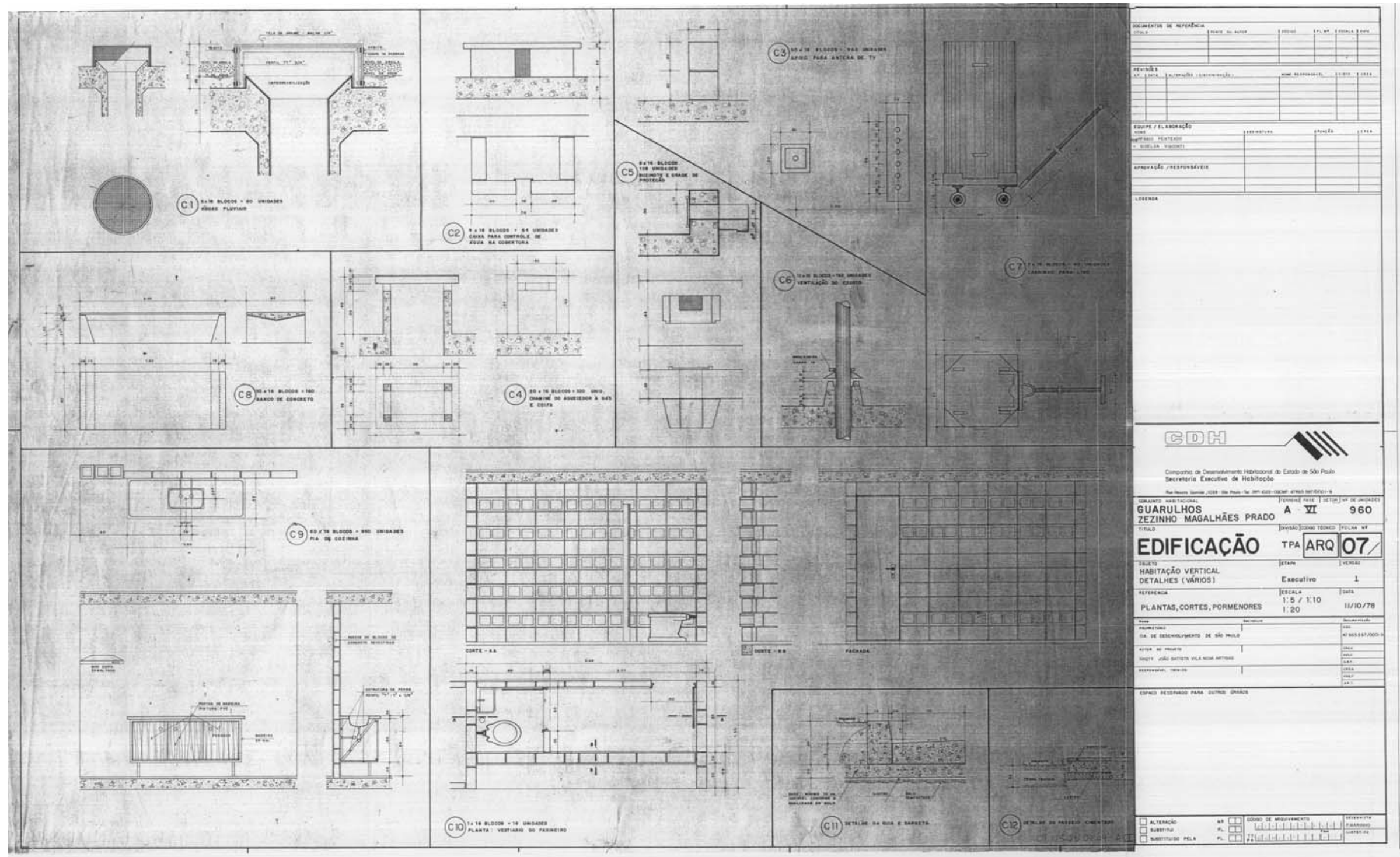


PLANTA 13

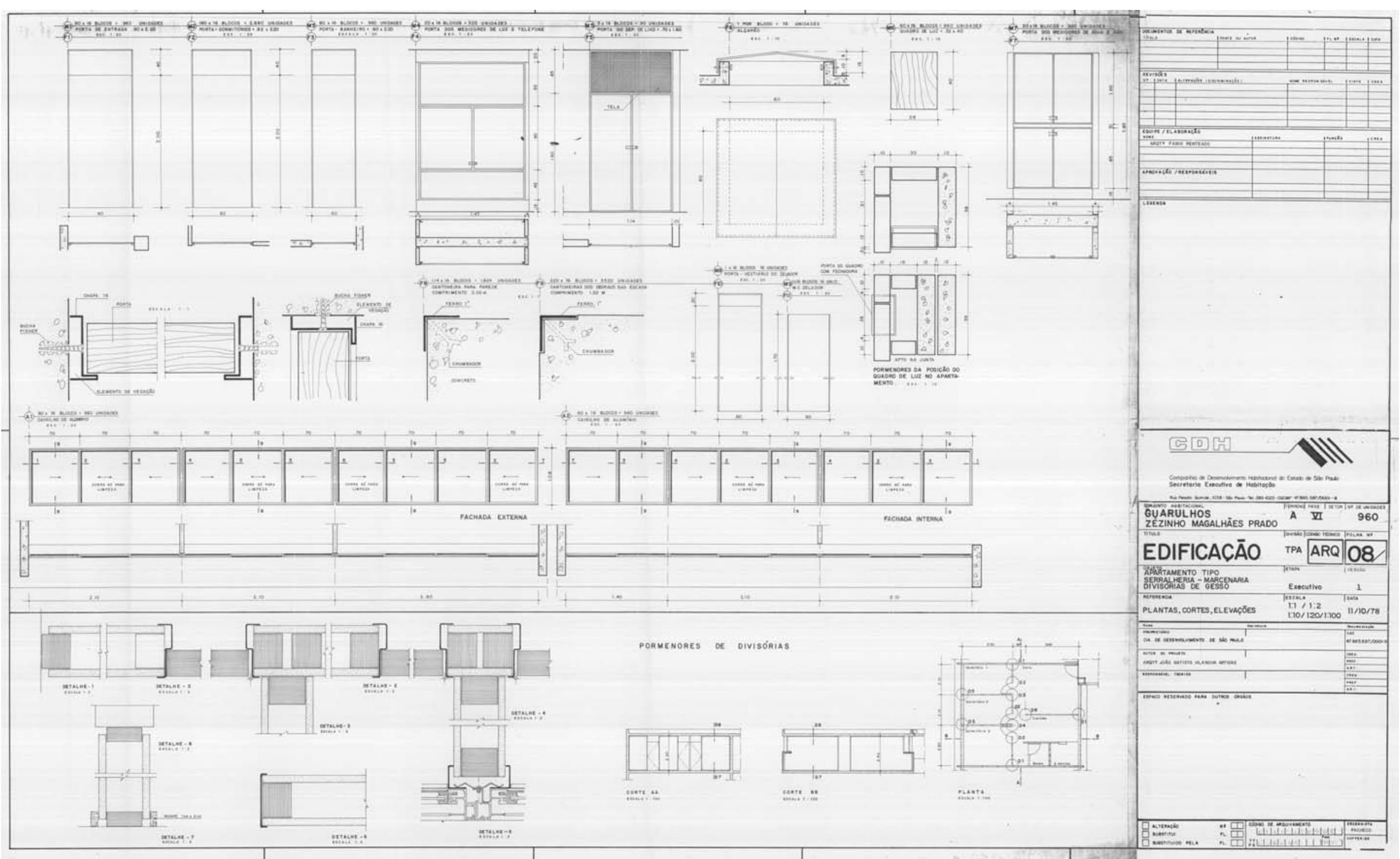




\section{PLANTA 14}

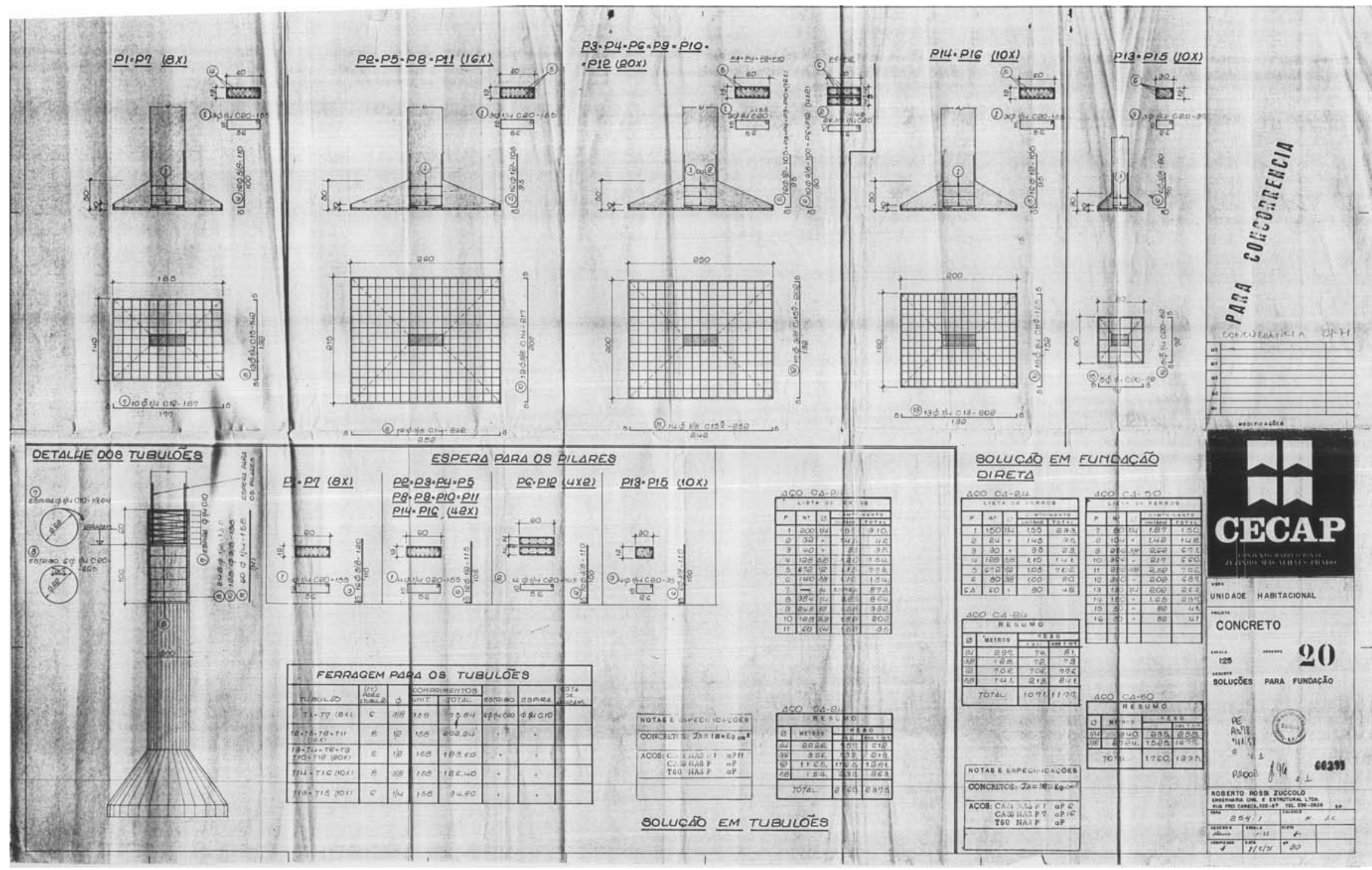




\section{PLANTA 15}

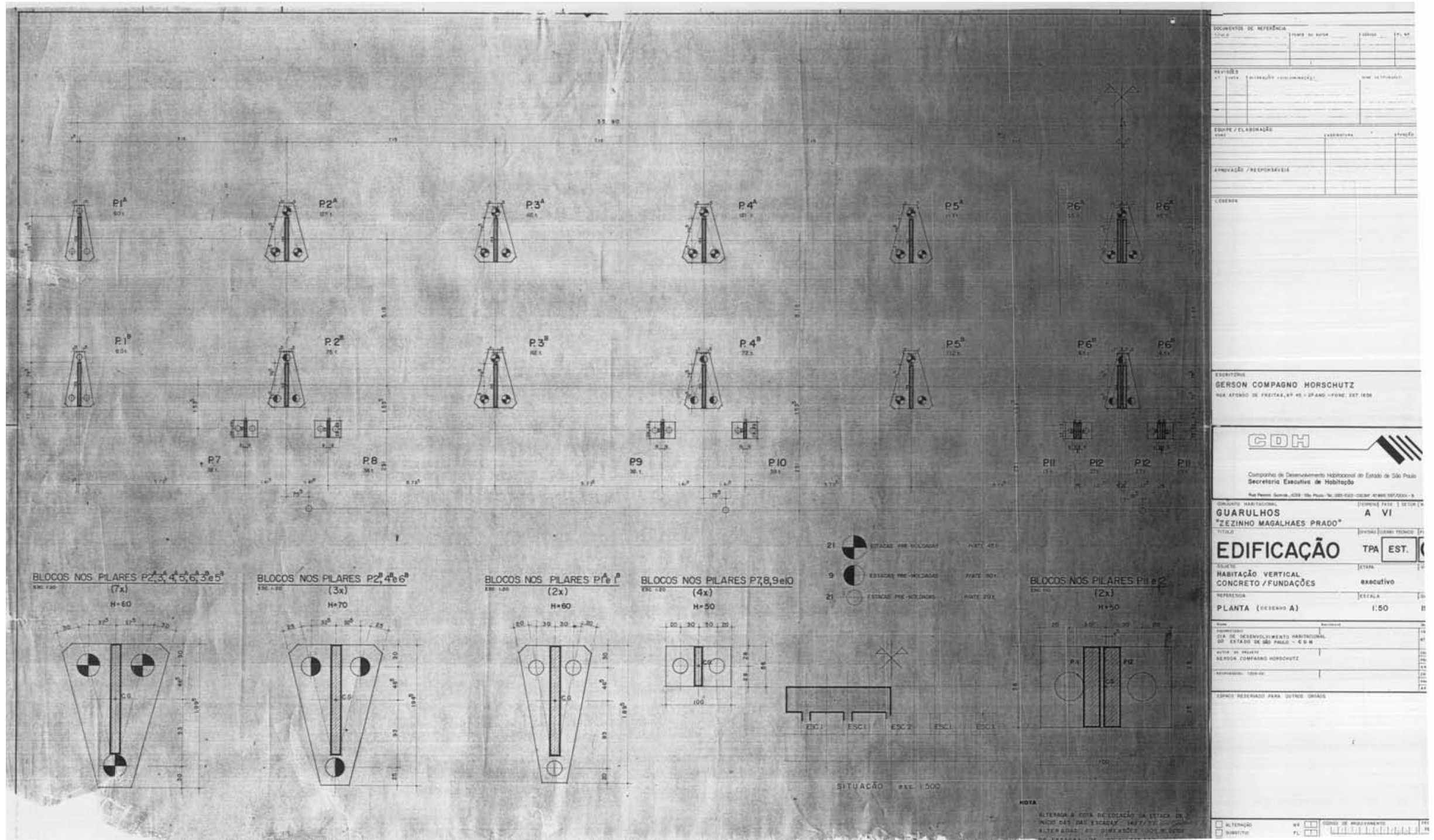


PLANTA 16

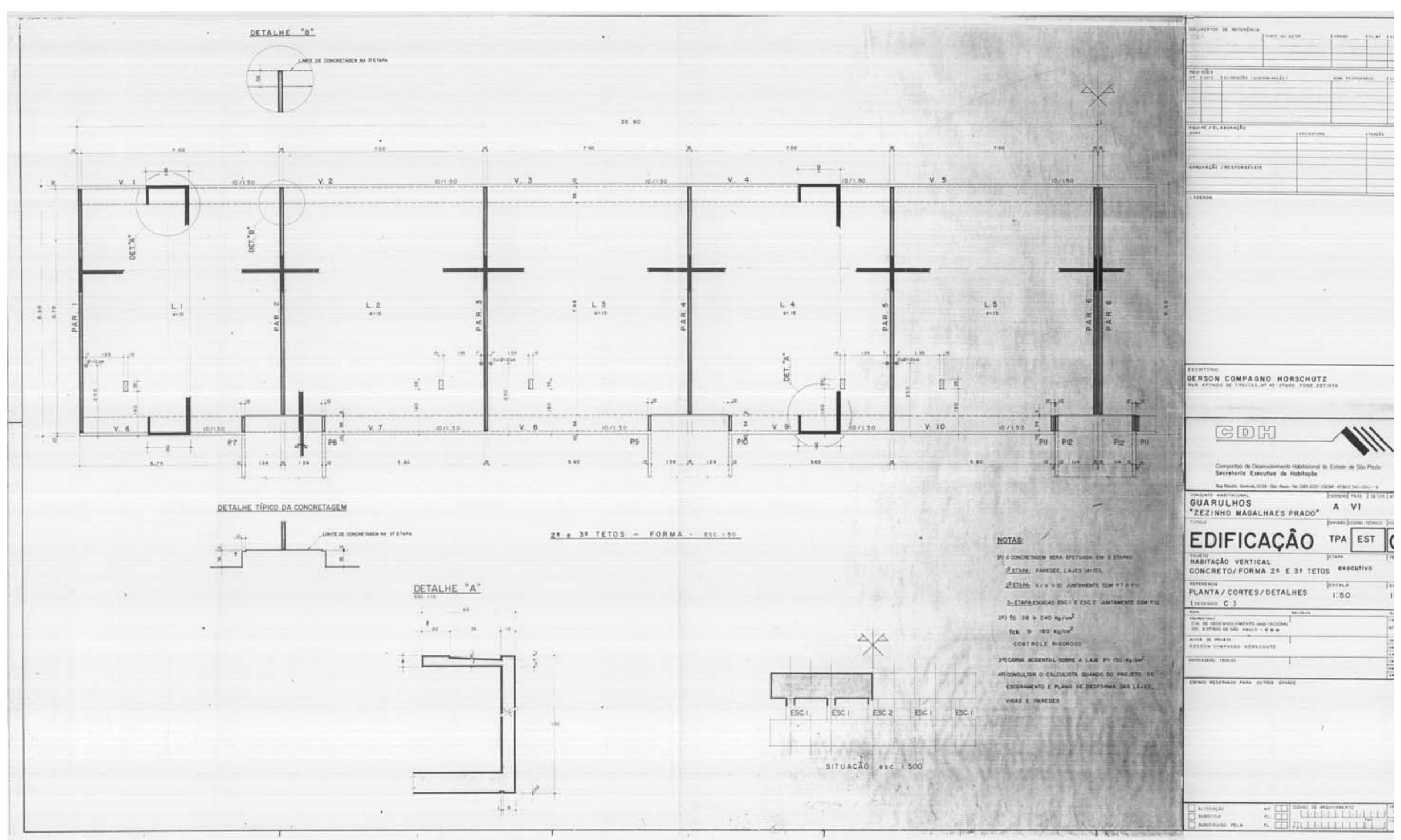


PLANTA 17

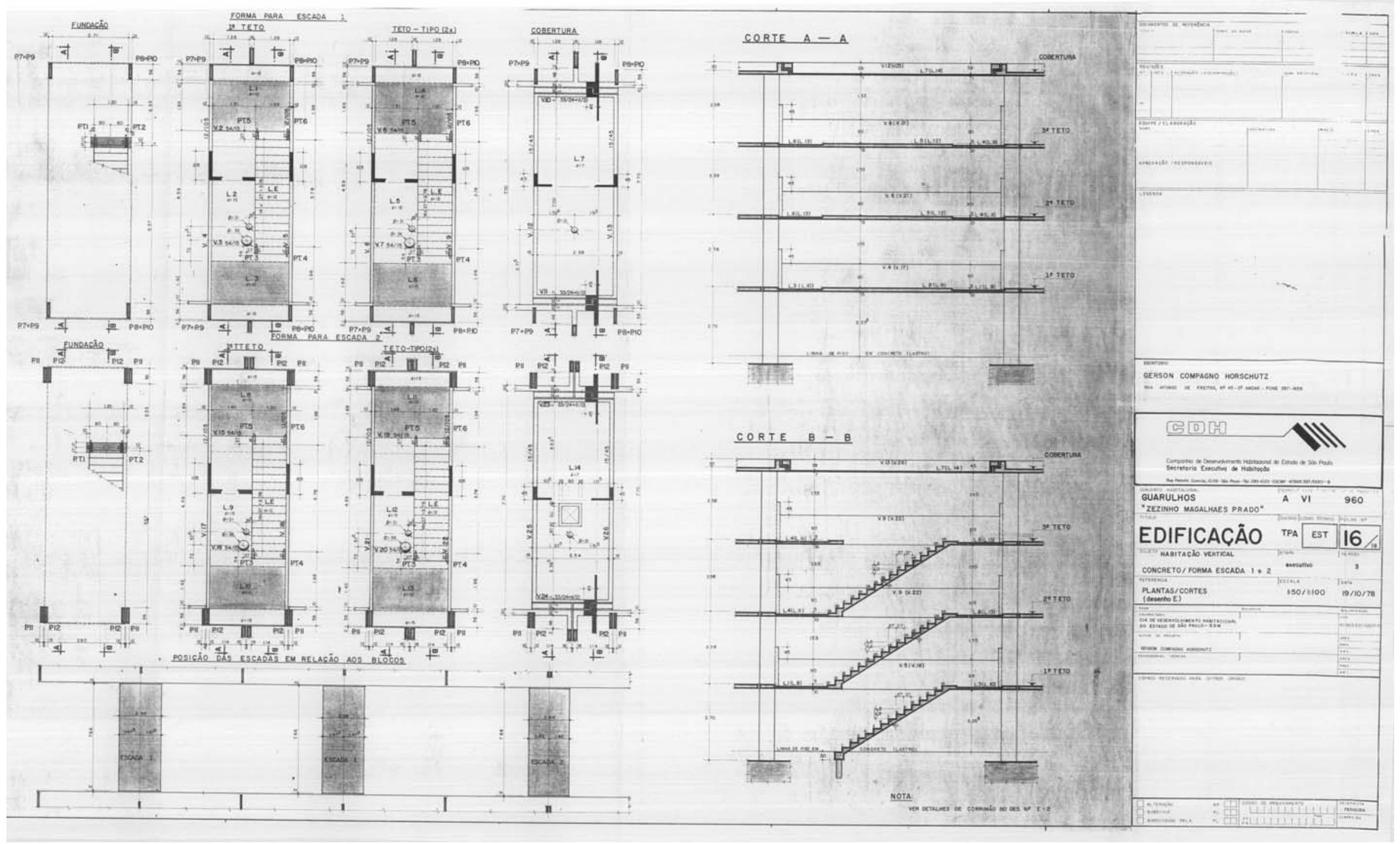


Lxxx| PLANTA 18

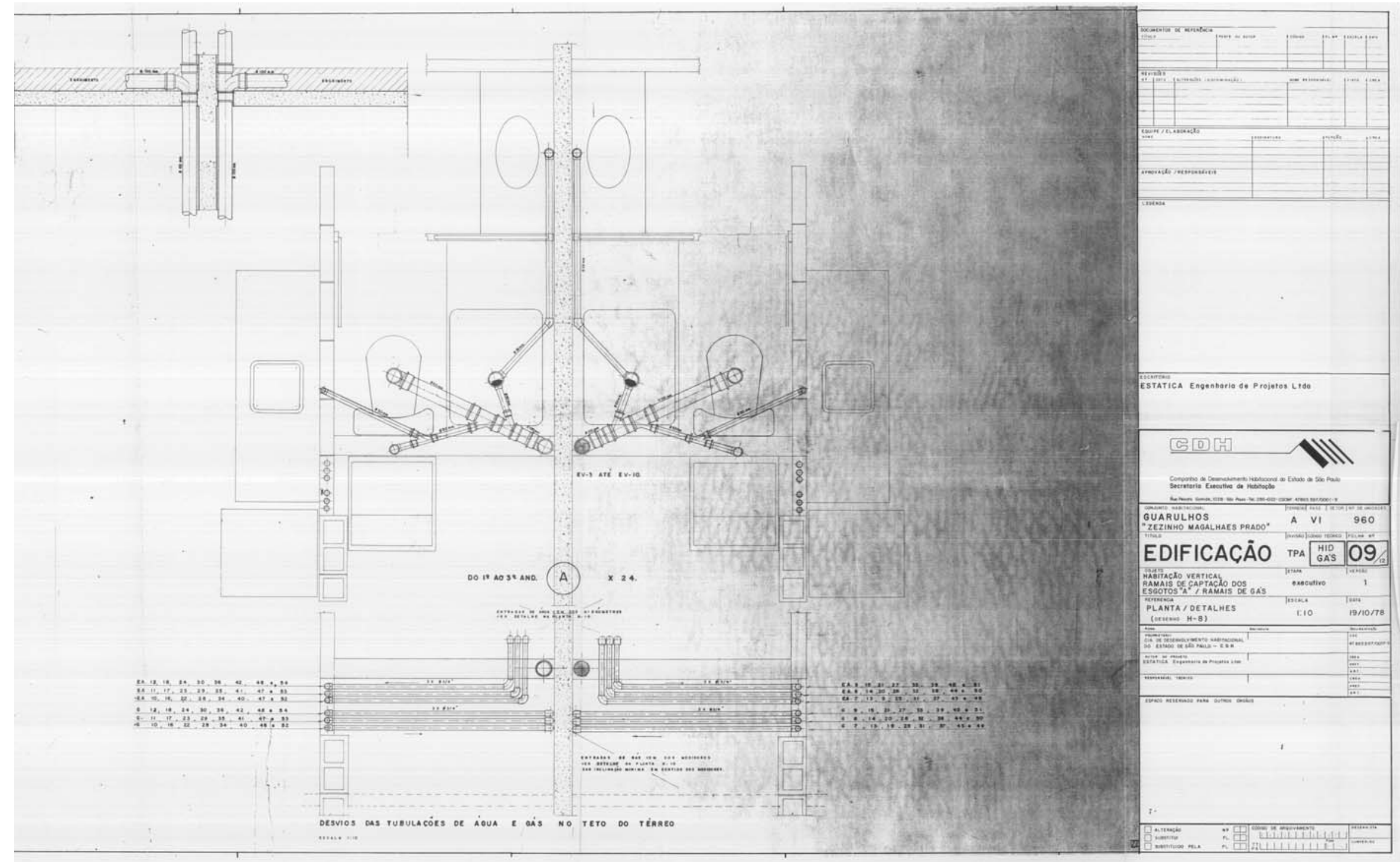




\section{PLANTA 19}

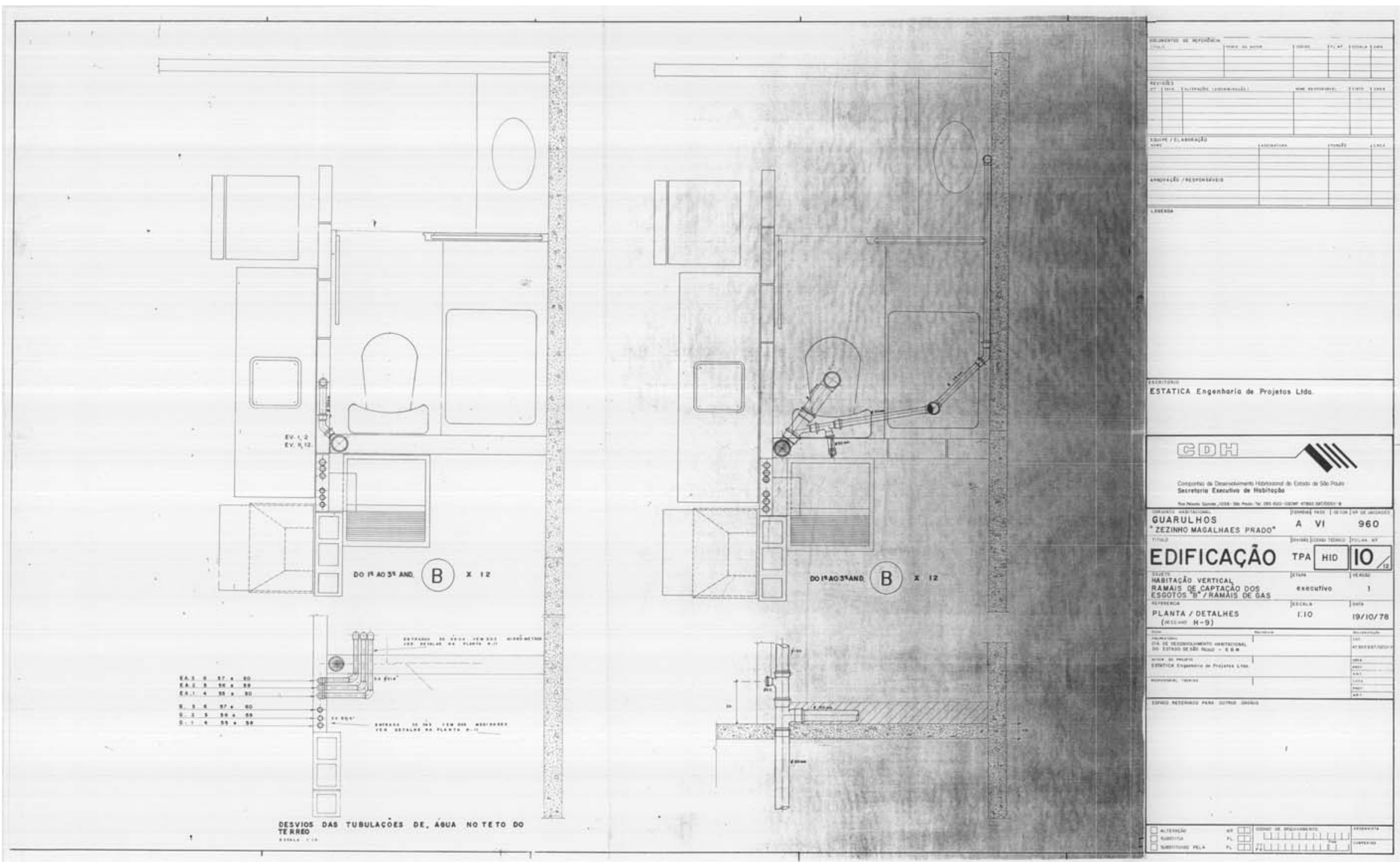


PLANTA 20

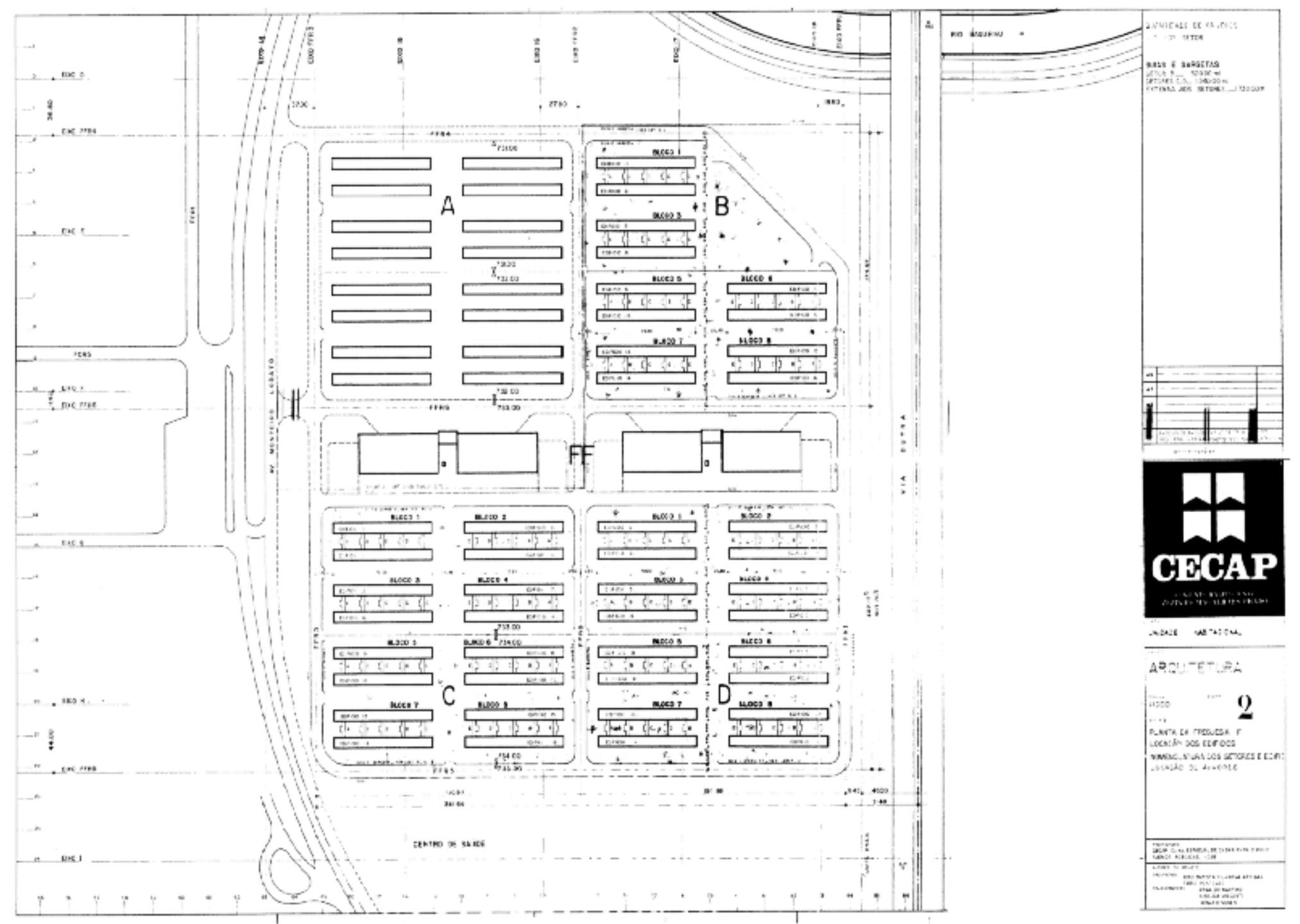


PLANTA 21

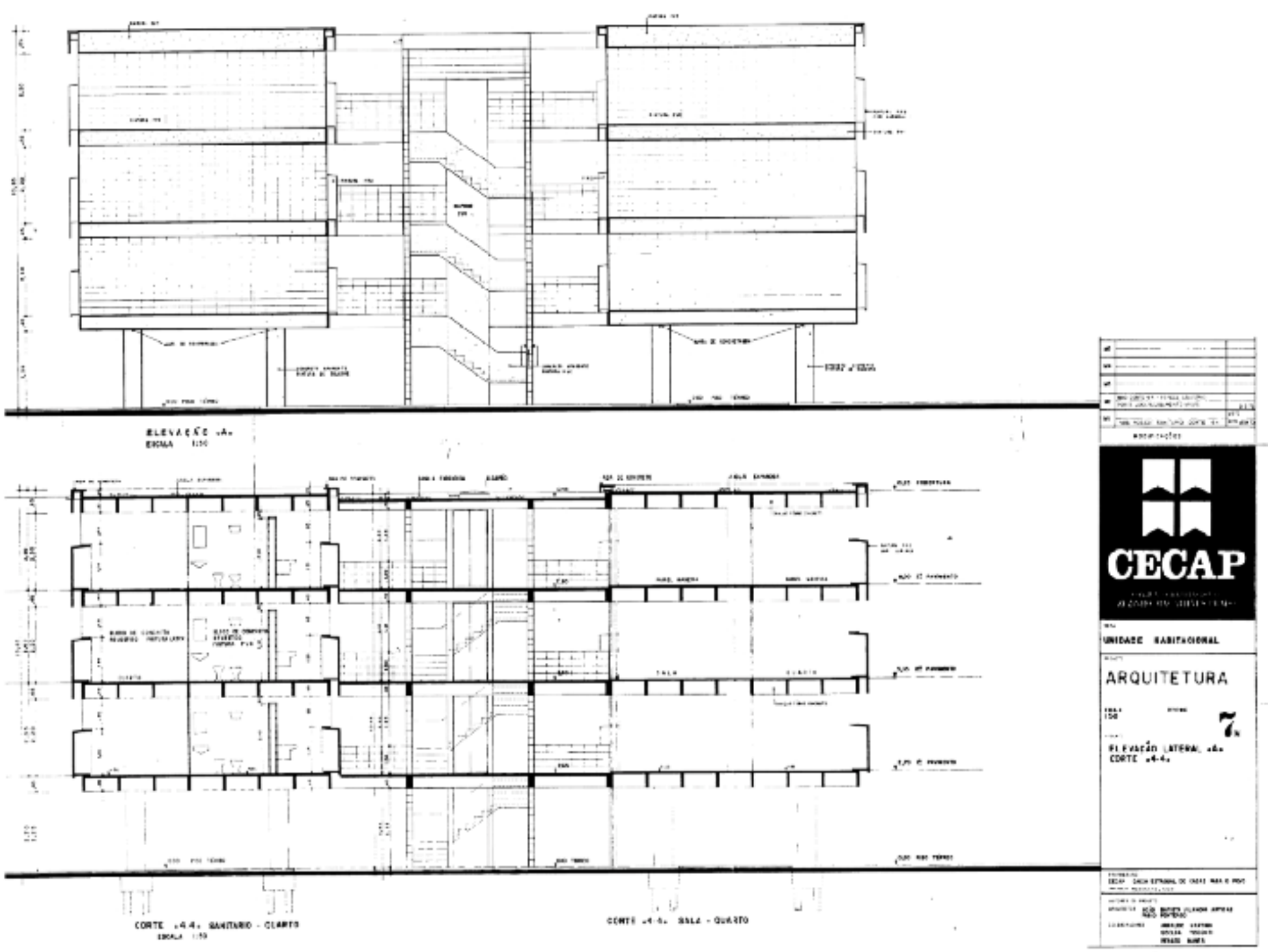


PLANTA 22
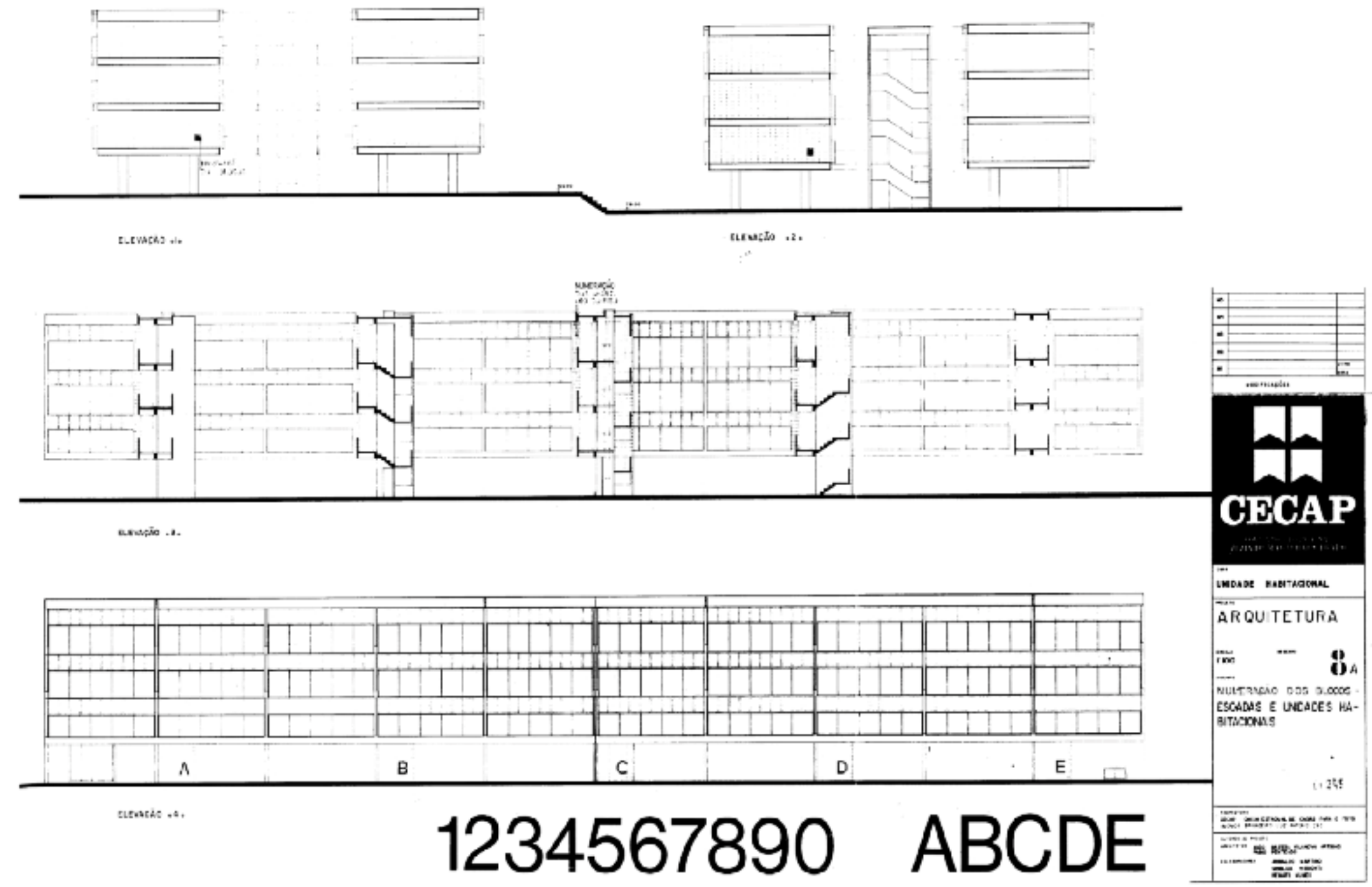


\section{PLANTA 23}

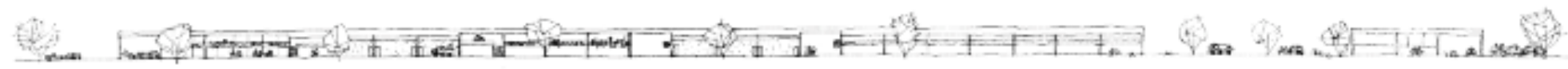

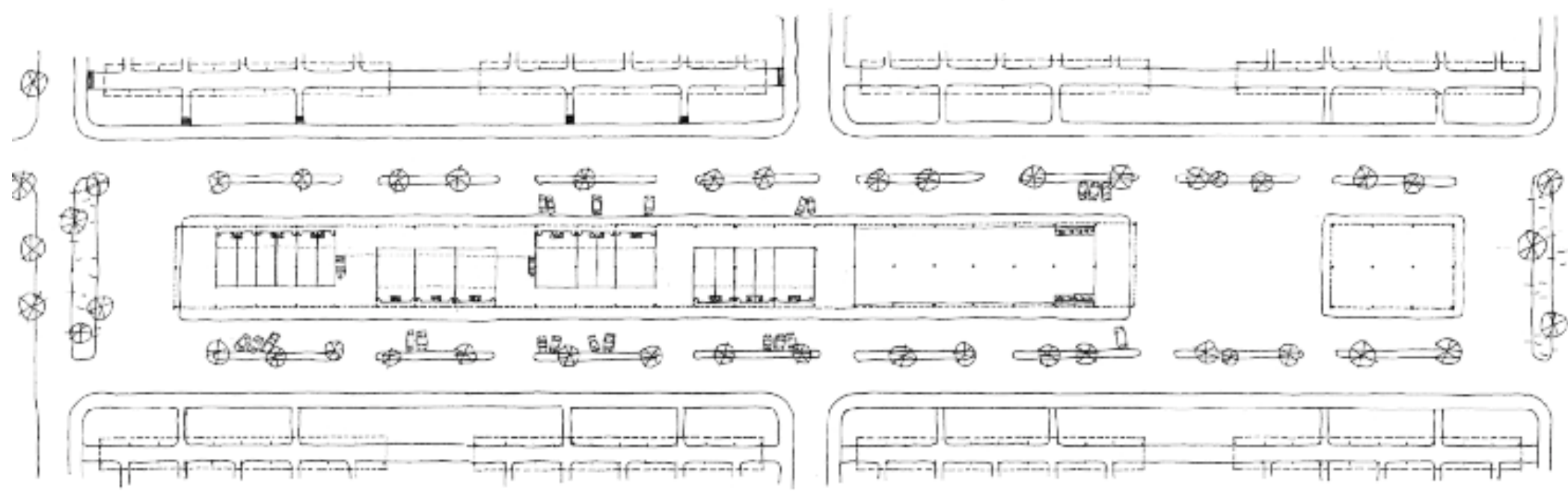


PLANTA 24

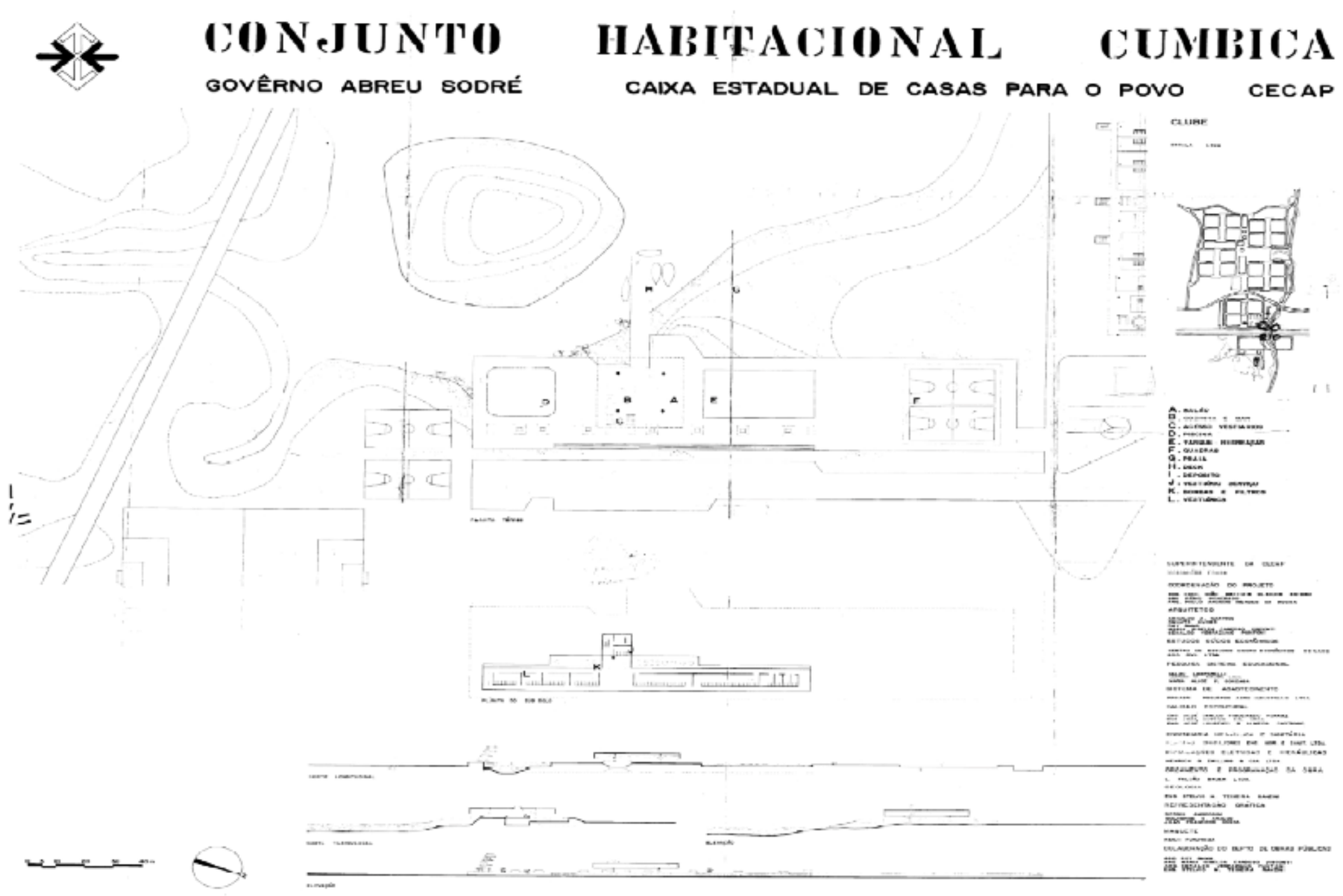




\section{PLANTA 25}
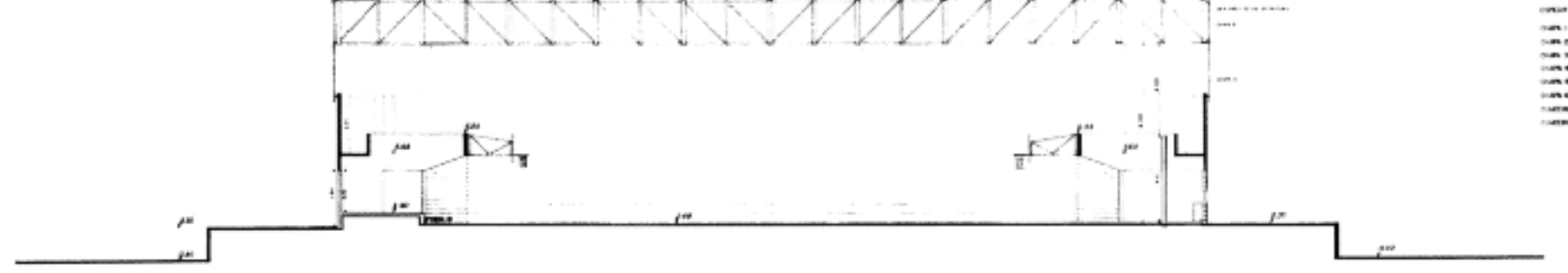

COPTE AA

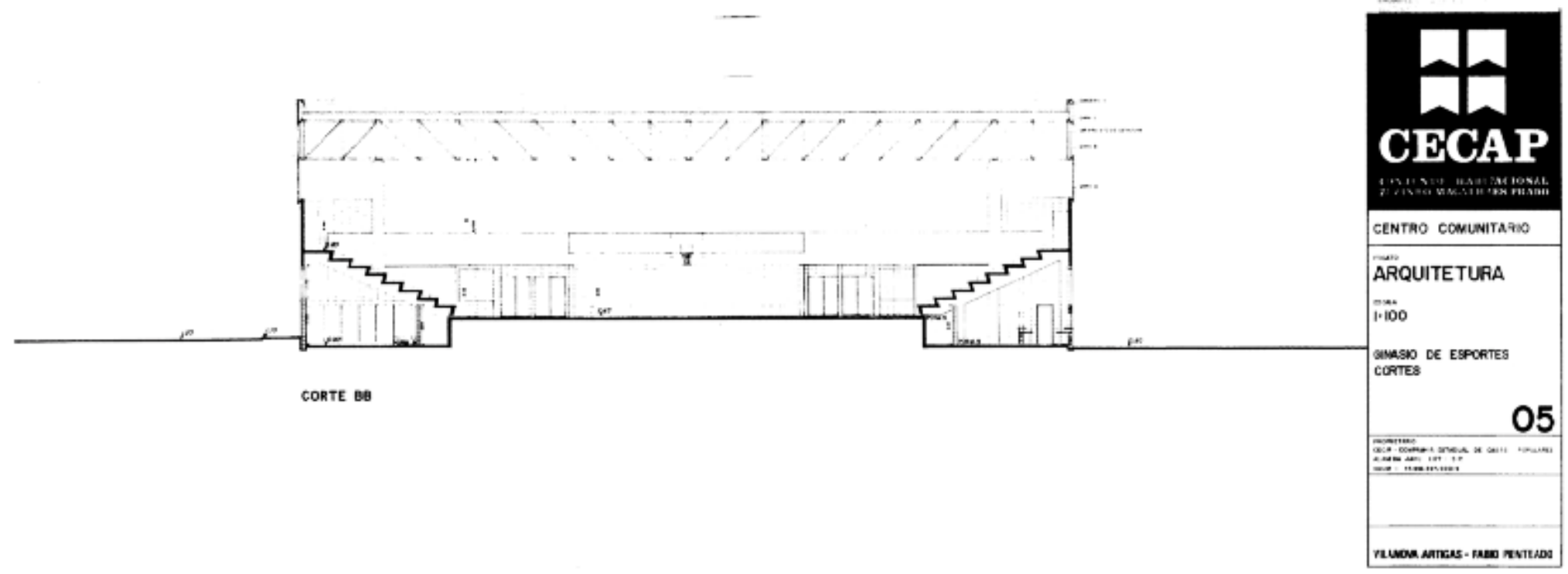


PLANTA 26

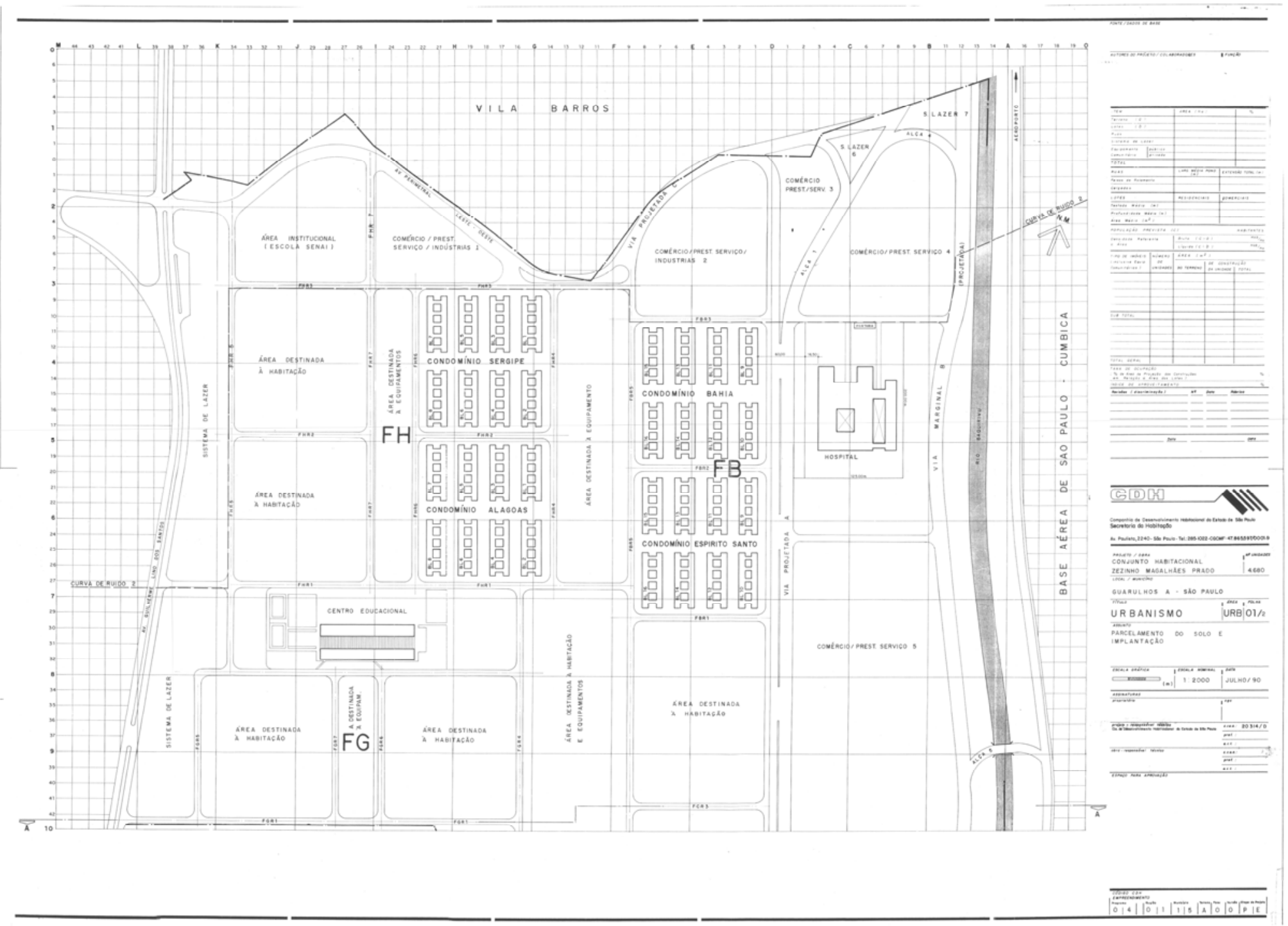


PLANTA 27

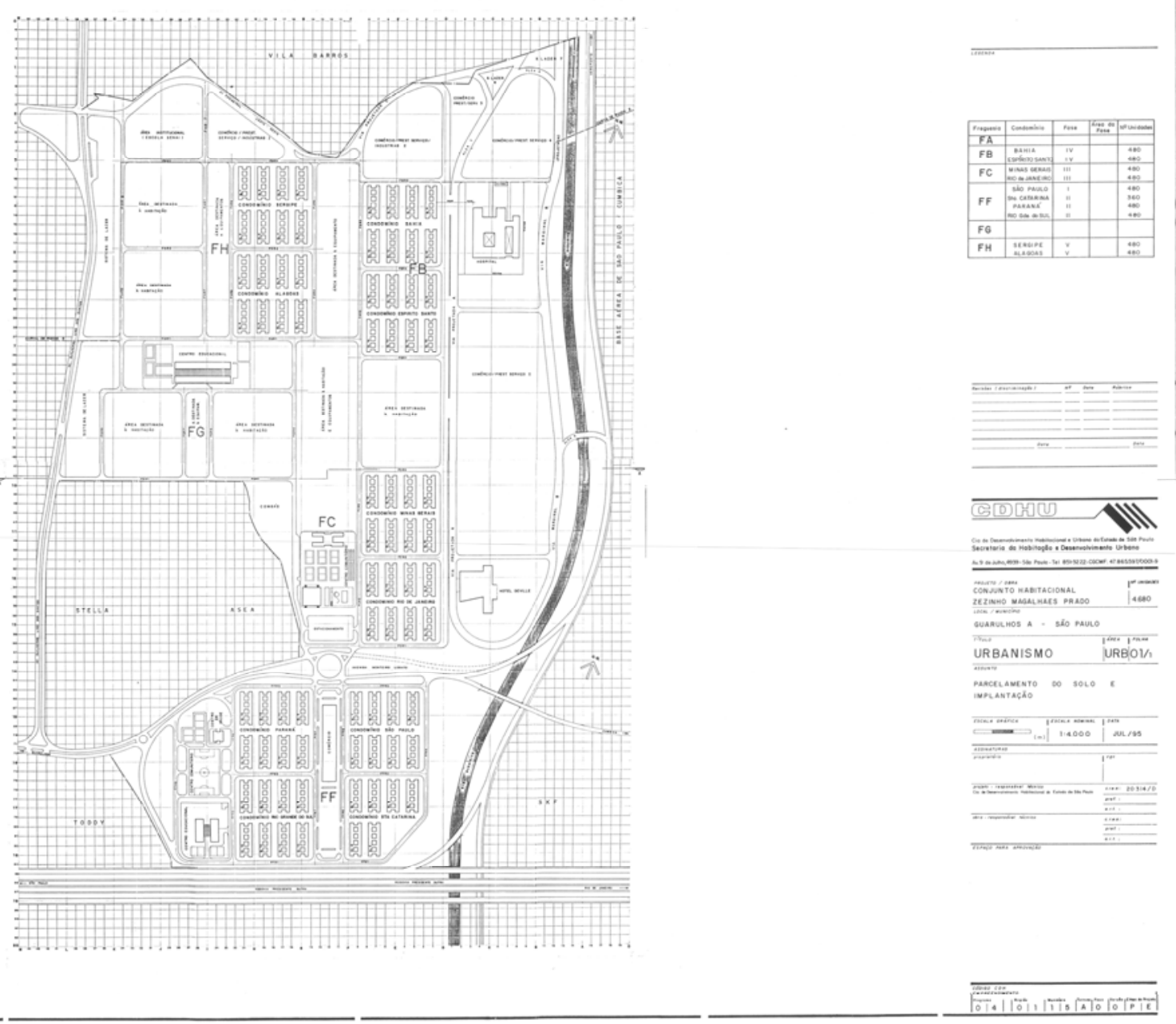

